Universidad Nacional de La Plata

Facultad de Ciencias Exactas

Departamento de Ciencias Biológicas

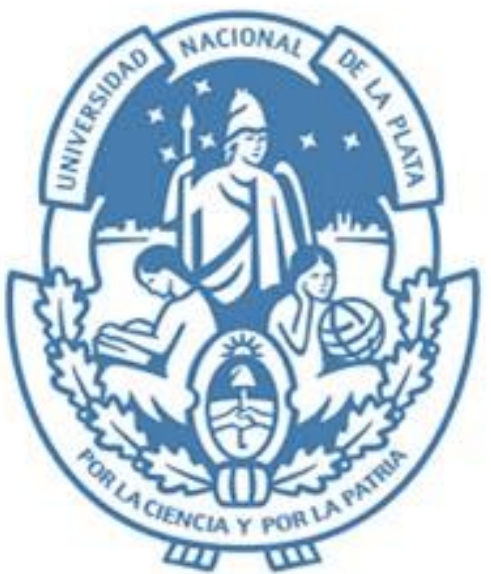

\title{
PRODUCTOS FERMENTADOS
}

\section{DESHIDRATADOS PROBIÓTICOS PARA LA}

\section{PREVENCIÓN DE GIARDIASIS}

\author{
Tesis Doctoral
}

Lic. Manuel Teijeiro

Directores: Dra. Marina A. Golowczyc y Dr. Pablo F. Perez 
El presente trabajo de Tesis, para optar por el título de Doctor de la Facultad de Ciencias Exactas (UNLP), fue realizado en el Centro de Investigación y Desarrollo en Criotecnología de Alimentos (CIDCA), UNLP-CONICET

CON I CET

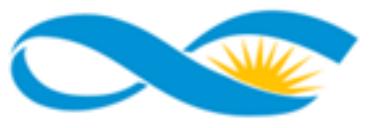

LA PLATA

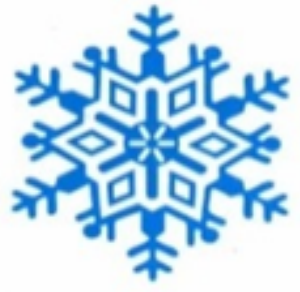

C I D C A

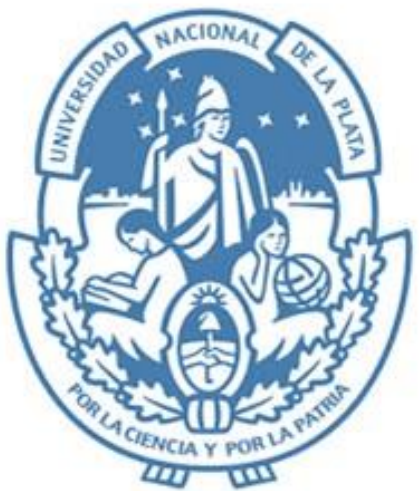


Los resultados del presente trabajo de tesis han sido publicados parcialmente en las siguientes instancias:

Artículos publicados en revistas:

Teijeiro, M.; Pérez, P. F.; De Antoni, G. L. y Golowczyc, M. A. (2018). Suitability of kefir powder production using spray drying. Food Research International, 112, 169-174. doi:10.1016/j.foodres.2018.06.023

Trabajos en eventos científico-tecnológicos no publicados:

Estudio del proceso de secado spray para obtener kefir en polvo. II Congreso Iberoamericano de Ingeniería de los Alimentos CIIAL. 2016. Punta del Este, Uruguay.

Almacenamiento de kefir deshidratado por secado en spray utilizando diferentes termoprotectores. XVI Congreso Argentino de Ciencia y Tecnología de Alimentos CYTAL - AATA. 2017. Mar del Plata, Argentina.

Obtención de kefir deshidratado mediante secado en spray y su acción contra Salmonella. XVI Congreso Argentino de Ciencia y Tecnología de Alimentos CYTAL - AATA . 2017. Mar del Plata, Argentina. 


\section{AGRADECIMIENTOS}

A mis directores de tesis, Marina y Pablo, por su tiempo, dedicación y conocimientos compartidos;

A Graciela De Antoni por darme la oportunidad de formarme y por su confianza;

Al CONICET por otorgarme la beca para desarrollar mi trabajo de tesis;

Al CIDCA y sus autoridades por permitirme desarrollar este trabajo en sus instalaciones;

A la UNLP, en especial a la Facultad de Ciencias Exactas, mi segunda casa;

A todos los que trabajan en el CIDCA, en especial a los integrantes del grupo de Microbiología;

A los compañeros becarios, por su amistad y apoyo;

A todas las personas que de algún modo u otro ayudaron a que pueda realizar el presente trabajo;

A los amigos;

A la familia;

A Lauren;

¡Muchas Gracias a todos! 
Índice

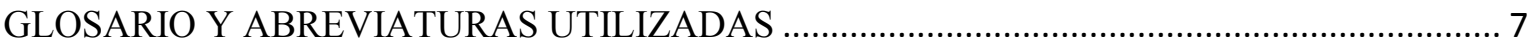

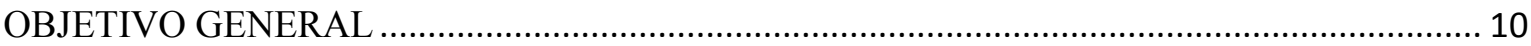

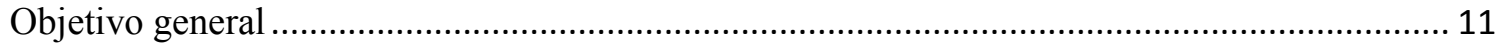

PRIMERA PARTE: DESARROLLO Y CARACTERIZACIÓN DE PRODUCTOS

DESHIDRATADOS CON CARÁCTER PROBIÓTICO A PARTIR DE KEFIR ............................ 12

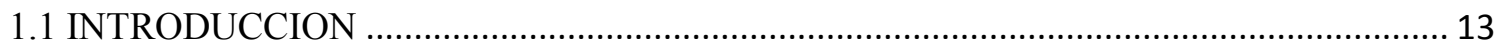

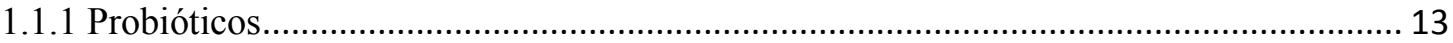

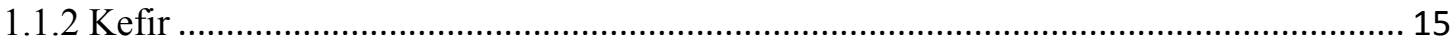

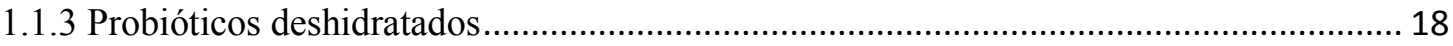

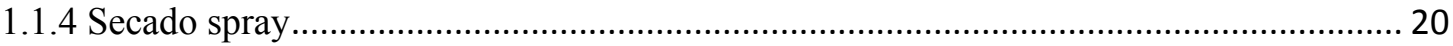

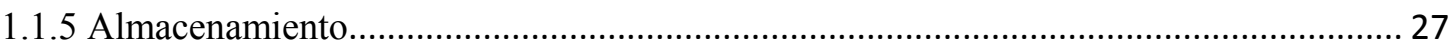

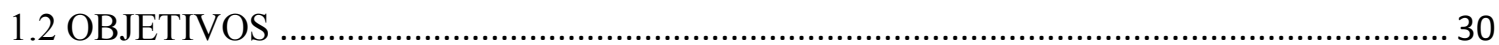

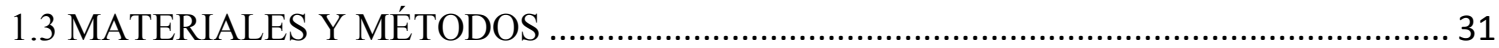

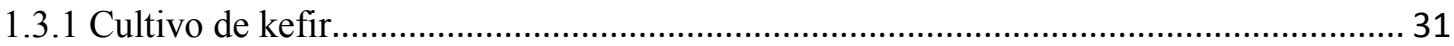

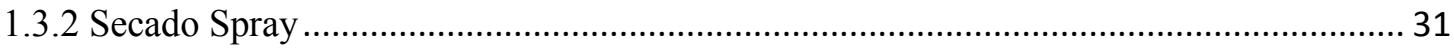

1.3.3 Caracterización de los productos deshidratados............................................................ 36

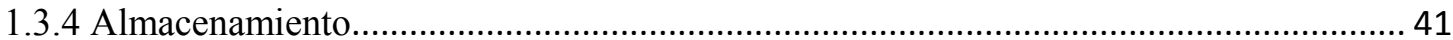

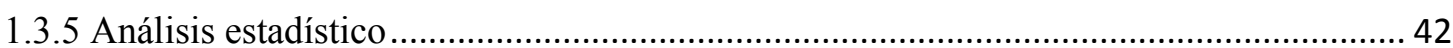

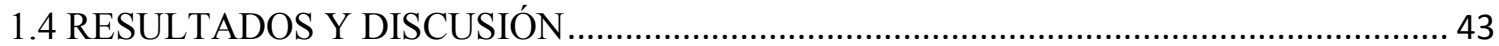

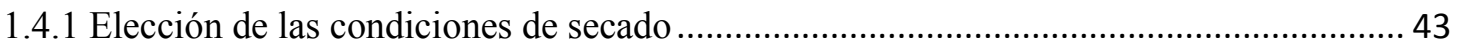

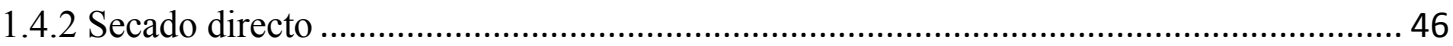


1.4.4 Almacenamiento de los productos obtenidos a escala laboratorio ................................. 82

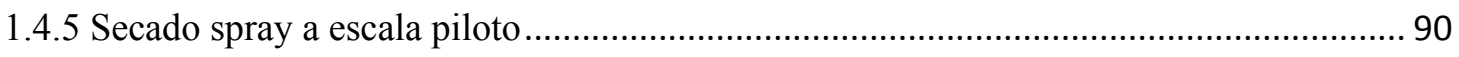

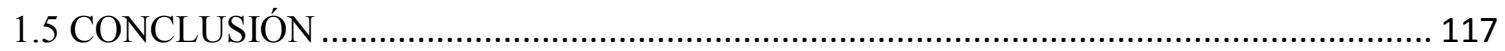

SEGUNDA PARTE: ESTUDIOS DE LA CAPACIDAD PROBIÓTICA DE LOS PRODUCTOS

DESHIDRATADOS DESARROLLADOS FRENTE A GIARDIA …...................................... 118

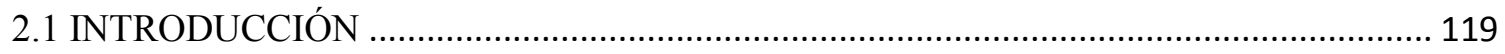

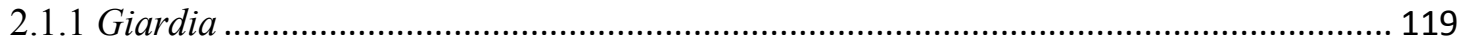

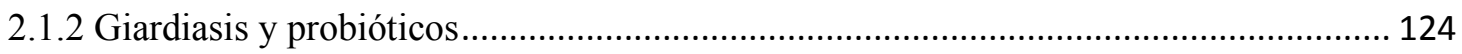

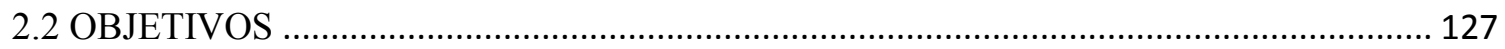

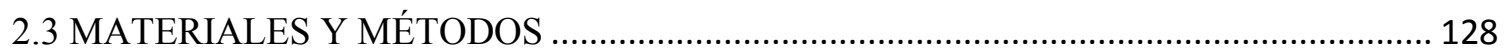

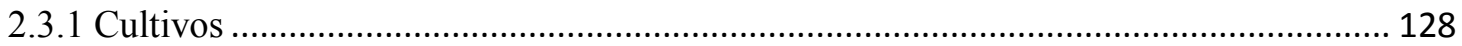

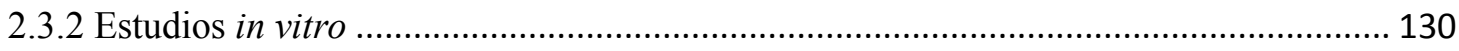

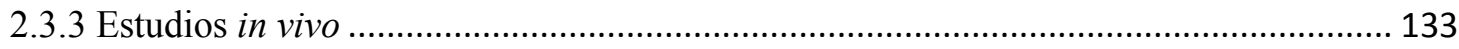

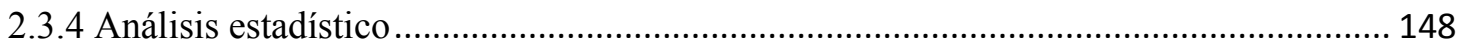

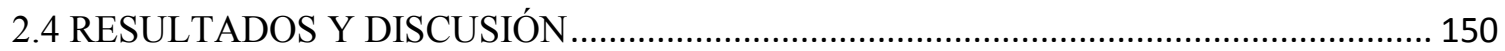

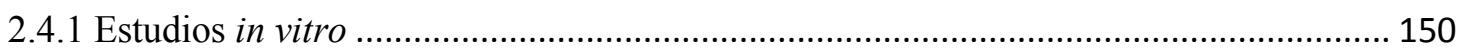

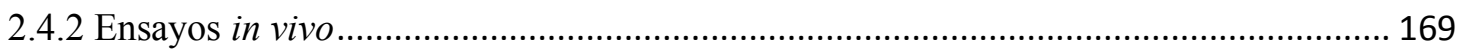

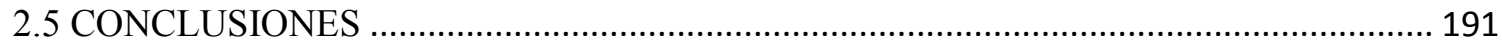

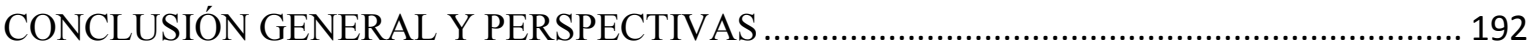

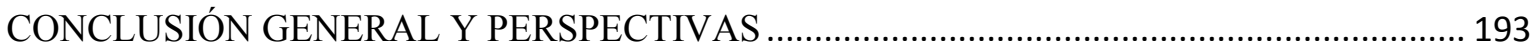

ANEXO 
Estudio de poblaciones hematopoyéticas de médula ósea por citometría de flujo.. 205 
ADN: Ácido desoxirribonucleico

APC: (del inglés: Allophycocyanin) aloficocianina

ARN: Ácido ribonucleico

aW: actividad de agua

Biot-St: (del inglés: Biotin/Streptavidin) Biotina/estreptavidina marcada

CIDCA: Centro de Investigación y Desarrollo en Criotecnología de Alimentos

cP: centipoise

DGGE: (del inglés: Denaturing Gradient Gel Electrophoresis) Electroforesis en gel con gradiente de desnaturalización.

DPI: días post infección

FAO: (del inglés: Food and Agriculture Organization) Organización de las Naciones Unidas para la Alimentación y la Agricultura.

FITC: (del inglés: Fluorescein isothiocyanate) Isotiocianato de fluoresceína

GALT: (del inglés: Gut-associated lymphoid tissue) Tejido linfoide asociado asociado con el intestino.

h: hora(s)

IgE: Inmunoglobulina-E

min: minuto(s)

ml: mililitros 
$\mu \mathrm{l}:$ microlitros

$\mu \mathrm{m}$ : micrómetros

OMS: Organización Mundial de la Salud

PCR: (del inglés: Polymerase Chain Reaction) Reacción en Cadena de la Polimerasa PE: (del inglés: Phycoerythrin) ficoeritrina

$\mathrm{p} / \mathrm{v}$ : peso en volumen

seg: segundo(s)

UFC: Unidades Formadoras de Colonia

UHT: (del inglés: Ultra High Temperature) Leche esterilizada

vs: versus 
TABLA RESUMEN DE MUESTRAS

\begin{tabular}{|c|c|c|c|}
\hline Producto & Carrier & Método de producción & Escala de producción \\
\hline KUHTdir & NO & Secado directo ( ver sección 1.3.2.1.3) & Laboratorio \\
\hline KWPdir & NO & Secado directo ( ver sección 1.3.2.1.3) & Laboratorio \\
\hline MT & Maltodextrina + Trehalosa & Secado con carrier (ver sección 1.3.2.1.4) & Laboratorio \\
\hline MTN & Maltodextrina + Trehalosa neutralizado & Secado con carrier (ver sección 1.3.2.1.4) & Laboratorio \\
\hline SM & Leche descremada & Secado con carrier (ver sección 1.3.2.1.4) & Laboratorio/Piloto \\
\hline SMG & Leche descremada + Glutamato monosódico & Secado con carrier (ver sección 1.3.2.1.4) & Piloto \\
\hline SML & Leche descremada + Lactosa & Secado con carrier (ver sección 1.3.2.1.4) & Piloto \\
\hline SMM & Leche descremada + Maltodextrina & Secado con carrier (ver sección 1.3.2.1.4) & Laboratorio/Piloto \\
\hline SMMN & Leche descremada + Maltodextrina neutralizado & Secado con carrier (ver sección 1.3.2.1.4) & Laboratorio \\
\hline SMN & Leche descremada neutralizado & Secado con carrier (ver sección 1.3.2.1.4) & Laboratorio \\
\hline SMS & Leche descremada + Sorbitol & Secado con carrier (ver sección 1.3.2.1.4) & Piloto \\
\hline SMT & Leche descremada + Trehalosa & Secado con carrier (ver sección 1.3.2.1.4) & Laboratorio \\
\hline SMTN & Leche descremada + Trehalosa neutralizado & Secado con carrier (ver sección 1.3.2.1.4) & Laboratorio \\
\hline WP & Permeado de suero & Secado con carrier (ver sección 1.3.2.1.4) & Laboratorio \\
\hline WPM & Permeado de suero + Maltodextrina & Secado con carrier (ver sección 1.3.2.1.4) & Laboratorio \\
\hline WPMN & Permeado de suero + Maltodextrina neutralizado & Secado con carrier (ver sección 1.3.2.1.4) & Laboratorio \\
\hline WPN & Permeado de suero neutralizado & Secado con carrier (ver sección 1.3.2.1.4) & Laboratorio \\
\hline WPT & Permeado de suero + Trehalosa & Secado con carrier (ver sección 1.3.2.1.4) & Laboratorio \\
\hline WPTN & Permeado de suero + Trehalosa neutralizado & Secado con carrier (ver sección 1.3.2.1.4) & Laboratorio \\
\hline
\end{tabular}


OBJETIVO GENERAL 
Objetivo general

El objetivo general del presente trabajo consistió en el desarrollo de un producto deshidratado a partir de kefir mediante secado spray, que conserve propiedades probióticas comparables al producto original y la evaluación de su posible efecto beneficioso para el hospedador frente a la infección por parte de Giardia intestinalis. 


\section{PRIMERA PARTE: DESARROLLO Y CARACTERIZACIÓN DE PRODUCTOS}

DESHIDRATADOS CON CARÁCTER PROBIÓTICO A PARTIR DE KEFIR 


\subsection{INTRODUCCION}

\subsubsection{Probióticos}

Desde hace varios años, tanto los profesionales de la salud, como el público en general han aumentado su interés hacia el consumo de probióticos y los beneficios a la salud que estos pueden conferir.

El término probiótico fue acuñado a principios del siglo XX por Eli Metchnikoff al investigar el alto promedio de vida de los campesinos búlgaros y relacionarlo con el consumo de leches fermentadas (Vasilevic y Shah, 2008). Metchnikoff afirmó que existía una dependencia de la microbiota intestinal con respecto a los alimentos que se consumen y que era posible sustituir los microbios nocivos por microbios útiles a los que denominó probióticos (Metchnikoff, 1907). Con el pasar de los años las definiciones del término probiótico fueron evolucionando y en 2001, expertos de la FAO y la OMS establecieron que son "microorganismos vivos que, cuando se consumen en cantidades apropiadas como parte de un alimento, confieren al huésped un beneficio para la salud".

Los probióticos pueden aportar beneficios en la mucosa y microbiota intestinal, disminuir el riesgo de infecciones y el desarrollo de enfermedades en el tracto digestivo y tener efectos beneficiosos sobre el sistema inmune.

Un microorganismo probiótico debe cumplir ciertas condiciones para ser considerado como tal. Estos criterios pueden agruparse en 3 categorías:

I) Criterios de seguridad: ser reconocido como un microorganismo seguro (GRAS, del inglés: Generally Recognized as Safe), ser genéticamente estables y no presentar resistencia a antibióticos dado el riesgo que existe de transferencia de dicha resistencia a microorganismos que causan enfermedades; 
II) Criterios tecnológicos: mantener una adecuada viabilidad a lo largo de todo el proceso que conduce a la producción del alimento del que forman parte, poder ser parte de procesos reproducibles a gran escala, poseer, preferentemente, resistencia a bacteriófagos, que el producto del que forman parte sea organolépticamente aceptable; y

III) Criterios funcionales: ser activos en el aparato digestivo, ser capaces de permanecer viables $\mathrm{y}$ de proliferar en el intestino $\mathrm{y}$ otorgar algún tipo de beneficio al huésped: favorecer la absorción y/o el metabolismo de nutrientes, favorecer el metabolismo del colesterol, regularizar la microbiota intestinal, antagonizar microorganismos nocivos, modular las defensas del organismo, $\mathrm{y}$, aportar a los requerimientos de vitaminas.

Los microorganismos probióticos han sido utilizados eficazmente contra diarreas producidas por rotavirus (Guandalini y col., 2000), diarreas asociadas a antibióticos que alteran la microbiota autóctona (Beausoleil y col., 2007) y diarreas producidas por infecciones bacterianas (Salmonella enterica serovar Typhimurium, Clostridium difficile, y Escherichia coli enteropatogénica) (Carey y col., 2008; Castillo y col., 2012; MaldonadoGaldeano y col., 2011; Salva y col., 2010; Zacarías y col., 2014).

Las enfermedades, el estrés, las dietas, la edad y los tratamientos con antibióticos son algunos de los factores que alteran la microbiota intestinal y el normal funcionamiento de la inmunidad, es por eso que los probiótico pueden colaborar a normalizar las funciones intestinales y promover mejores respuestas inmunológicas. (Borchers y col., 2009; KoppHoolihan, 2001; Maldonado Galdeano y col., 2019; Yan y Polk, 2011; Wang y col, 2018). Los probióticos pueden ser capaces de modular las defensas del organismo. Existen antecedentes de trabajos que demuestran que los microorganismos probióticos pueden ayudar a mantener la función barrera del epitelio intestinal y evitar desbalances en la 
microecología del intestino (Isolauri y col. 2001; Rao y Samak, 2013). Frente a antígenos de microorganismos patógenos y alimentos, los probióticos pueden aumentar la barrera de defensa en el intestino, estimulando la producción de IgA o activando las células NK (Takeda y col. 2006). También pueden incrementar la actividad fagocítica de leucocitos intestinales (Sheih y col. 2001), promover la proliferación de linfocitos B (Kitazawa y col. 2001) y de citoquinas (IL-2, IL-6, IL-8, IL-10) o regular la producción del factor de necrosis tumoral (TNF). (Bui y col., 2015; De Moreno de Le Blanc y col., 2011; MaldonadoGaldeano y col, 2019; Resta-Lenert y col., 2015; Van Hemert y col., 2010; Yan y Polk, 2011).

Los alérgenos alimentarios pueden provocar una respuesta inflamatoria en el intestino por alteración de la función inmunológica. Existen estudios que verifican una disminución de las alergias ante el tratamiento con probióticos (Kuitunen y col., 2009; Rosenfeldt y col., 2004; Sharma e Im, 2018). Los mecanismos por los cuales esto ocurre no son conocidos con certeza pero se postula que los probióticos podrían modificar la permeabilidad intestinal o bien intervenir sobre la producción de citoquinas que promueven la secreción de IgE (SmithNorowitz y Bluth, 2015).

\subsubsection{Kefir}

El kefir es una leche fermentada artesanal, originada y consumida masivamente en la región del Cáucaso y el este europeo y es una fuente potencial de microorganismos probióticos (Bengoa y col., 2019; Garrote y col., 2010; Leite y col., 2013). El fermento propio del kefir lo constituyen los gránulos de kefir, una matriz de polisacárido y proteínas, que contienen una compleja mezcla de bacterias (mayoritariamente lactococos, lactobacilos y bacterias ácido acéticas, aunque pueden aparecer otras especies) y levaduras (fermentadoras y no fermentadoras de lactosa). La composición microbiana de dichos gránulos y la abundancia relativa de una u otra especie depende de su procedencia, de las condiciones de cultivo y del 
almacenamiento y manipulación de los gránulos. La leche fermentada se destaca por su viscosidad, su sabor ácido (por la producción de ácido láctico y acético) y su aroma característico (Otles y Cagindi, 2003).

El carácter probiótico del kefir o de los microorganismos aislados ha sido ampliamente reportado por la comunidad científica. El kefir tiene un amplio espectro de importantes beneficios para la salud, que incluyen propiedades fisiológicas, profilácticas y terapéuticas. Estos efectos son el resultado de una amplia variedad de compuestos bioactivos producidos durante el proceso de fermentación (como ácidos orgánicos, vitaminas, diversas proteínas y exopolisacáridos) y la microbiota altamente diversa, que actúa de forma independiente o sinérgica para generar un beneficio para la salud (Rosa y col., 2017). Entre estas propiedades probióticas se destacan el antagonismo contra patógenos intestinales y las propiedades antimicrobianas (Garrote y col., 2000; Golowczyc y col., 2007; Kim y col., 2016; Silva y col., 2009) y la modulación de la respuesta inmune y la microbiota del hospedador (Carasi y col, 2015; Marquina y col., 2002; Vinderola y col., 2005, 2006).

Si bien el sustrato tradicional para la preparación de kefir es la leche, varias investigaciones han propuestos nuevos sustratos para la fermentación con los gránulos (Athanasiadis y col., 2002; Gamba y col., 2016; Londero y col., 2015; Silva y col., 2018) En este sentido, se destacan aquellos sustratos que constituyen un subproducto de la industria láctea, como el suero de leche. El suero de leche constituye una excelente fuente de nutrientes, pero a su vez, es uno de los subproductos más contaminantes de la industria alimentaria, ya que se continúa desechando y formando parte de los efluentes contaminantes de las industrias lácteas. Este problema se debe principalmente a que 1000 litros de suero lácteo generan una demanda biológica de oxígeno (DBO) de aproximadamente $35 \mathrm{~kg}$ y una demanda química de oxígeno (DQO) de unos $68 \mathrm{~kg}$. Al verter el suero en un cuerpo de agua los microorganismos necesitan una gran cantidad del oxígeno para degradarlo y como 
consecuencia disminuye la concentración de oxígeno disuelto provocando un desequilibrio en estos ecosistemas (Muset y Castells, 2017). Hoy en día, existen numerosas políticas para concientizar acerca de este problema ambiental y promover el procesamiento del suero lácteo para generar productos con mayor valor agregado. El permeado de suero, por ejemplo, es un producto resultante de la ultrafiltración del suero lácteo y una posterior osmosis inversa para su concentración. Este producto ha sido utilizado exitosamente como suplemento para la alimentación animal, y también se ha propuesto e investigado su uso como medio para la fermentación de diferentes microorganismos (Gallardo y col., 2001; Parashar y col., 2016). Los reportes acerca del uso del permeado de suero y otros derivados del suero lácteo como sustrato para la fermentación de kefir mostraron que permitía obtener un producto con un número de bacterias lácticas y levaduras comparable al kefir elaborado en leche, mostrando una cinética de acidificación similar y una menor viscosidad tras la fermentación (Gamba 2016).

Aunque el kefir es comercializado en algunos países, la fabricación industrial presenta una serie de inconvenientes con respecto a la estandarización del producto y a la vida útil. Para la elaboración de kefir a escalas industriales se suele utilizar una selección de cepas provenientes del producto artesanal o un subcultivo proveniente de un cultivo madre a gran escala (Leite y col., 2013). Además de las dificultades propias que genera la estandarización de un producto conteniendo diversos microorganismos, uno de los desafíos más importantes radica en que los productos comerciales basados en kefir suelen requerir refrigeración para su transporte y almacenamiento, lo cual genera costos elevados en la logística que lo hacen poco atractivos comercialmente. Teniendo en cuenta la creciente demanda de productos probióticos y/o que aporten un beneficio a la salud, la búsqueda de nuevas presentaciones que faciliten el transporte y el almacenamiento, como un producto 
deshidratado en polvo, representa una innovación que ayudaría a la difusión y popularización de este tipo de bebidas.

\subsubsection{Probióticos deshidratados}

La mayoría de los probióticos comerciales disponibles en el mercado forman parte de alimentos de la industria láctea (yogures y leches fermentadas). La industria y el mercado de productos probióticos han crecido enormemente durante la última década, y se cree que para 2023 el mercado de los probióticos superará los 65 billones de dólares (Global Market Insights, 2016; Reid y col., 2019).

Tradicionalmente se utilizaron fermentos líquidos como cultivos starters para inocular productos lácteos, como ya se mencionó para el caso del kefir elaborado a escala industrial. Los avances en la biotecnología llevaron a la aplicación de cultivos concentrados deshidratados o liofilizados, otorgando una ventaja tecnológica a la industria ya que se elimina el subcultivo en la planta, reduce los costos asociados con la preparación de cultivos a granel y reduce el riesgo de infección por bacteriófagos (Santivarangkna y col., 2007). Por lo tanto, hoy en día se busca reemplazar los cultivos starter líquidos artesanales con cultivos comerciales concentrados (Hansen, 2002).

Aunque la liofilización es la técnica de deshidratación convencional utilizada comercialmente por los fabricantes de cultivos starter, ésta es más larga y costosa que otros procesos de secado.

Tabla 1: Costos de diferentes procesos de deshidratación tomando como referencia el proceso de liofilización. Adaptado de Santivarankga y col. 2007.

\begin{tabular}{|lcc|}
\hline Proceso de secado & Costo Fijo (\%) & Costo Manufactura (\%) \\
\hline Liofilización & 100 & 100 \\
\hline Secado por vacío & 52,2 & 51,6 \\
\hline Secado Spray & 9,3 & 24,1 \\
\hline Secado en lecho fluidizado & 8,8 & 17,9 \\
\hline
\end{tabular}


En la Tabla 1 se muestran los costos de los diferentes métodos de secado comparados con la liofilización (Santivarangkna y col., 2007). Se han hecho muchos intentos para desarrollar procesos de secado alternativos de menor costo, y algunos autores han observado resultados positivos en cuanto a la viabilidad luego del proceso (Cardona y col., 2002; Cui y col., 2018; Efiuvwevwere y col., 1999; Fu y col., 1995; Gardiner y col., 2000; Huang y col., 2018; Millqvist-Fureby y col., 2000; Rivero y col, 2009). El secado spray se puede utilizar como alternativa a la liofilización porque permite intensificar la transferencia de calor y masa, organizar procesos continuos y generar un producto deshidratado de alta calidad (Menshutina y col., 2010).

El secado spray de microorganismos se remonta a 1914 en el marco del estudio de Rogers sobre secado de bacterias lácticas (Rogers, 1914). Desde entonces, se han publicado numerosos trabajos sobre el secado spray de bacterias para superar las dificultades involucradas en el manejo y mantenimiento de cultivos líquidos (Boza y col., 2004; Teixeira y col., 1995). La velocidad de secado, la capacidad de producción continua, así como el bajo costo de producción del secado spray hace que sea más eficiente energéticamente en comparación con la liofilización (Tabla 1). Sin embargo, en comparación con otros métodos de secado, el secado spray de cultivos microbianos ha sido menos desarrollado comercialmente. Las razones de esto son principalmente las bajas tasas de supervivencia durante el secado de los cultivos, la baja estabilidad durante el almacenamiento y la dificultad para rehidratar el producto (Ananta y col., 2005; Boza y col., 2004; Chavez y Ledeboer, 2007; Mauriello y col., 1999; Teixeira y col., 1995). Sin embargo, es un proceso económico para la producción de cantidades a escala industrial de microorganismos viables y su aplicación para generar preparaciones de bacterias lácticas ha recibido recientemente un interés considerable (Barbosa y col., 2015; Santivarankga y col. 2007). 
Con respecto a la deshidratación de kefir, la mayor parte de las investigaciones se han realizado mediante liofilización (Brialy y col., 1995; Chen y col., 2006; Maki y col., 2017; Umeda y col., 2005). Los resultados en cuanto a la viabilidad microbiológica y al comportamiento durante el almacenamiento son variables. Así, la mayoría de los esfuerzos se han basado en optimizar las condiciones de congelamiento y de operación del equipo liofilizador y/o el uso de diferentes sustancias carriers para optimizar estos aspectos (Bergmann y col., 2010; Brialy y col., 1995; Chen y col., 2006; Conde-Islas y col., 2019)

En cuanto a la deshidratación por secado spray, la mayoría de las investigaciones en este sentido se realizaron fundamentalmente sobre diferentes cepas aisladas de la leche fermentada (Golowczyc y col., 2010; Hugo y col., 2016). Sin embargo, las investigaciones acerca de la deshidratación del kefir tal cual se obtiene tradicionalmente son prácticamente nulas. Sólo existe un antecedente en la bibliografía, que fue realizado para la misma época en que se realizaba este trabajo de tesis (Atalar y Dervisoglu, 2015). En dicho trabajo, se optimizaron las condiciones de secado spray haciendo foco en obtener la máxima supervivencia de tres géneros bacterianos (Lactobacillus, Lactococcus y Leuconostoc) y si bien los autores destacan que el producto obtenido es semejante al que se puede obtener mediante liofilización, remarcan el hecho de que se necesitan aún más investigaciones respecto al secado spray de kefir y la optimización del proceso. Además, destacan que el desarrollo de kefir deshidratado podría ampliar el consumo hacia un mayor público ya que la producción artesanal suele ser engorrosa y difícil de estandarizar.

\subsubsection{Secado spray}

El concepto de secado spray fue patentado por primera vez por Samuel Percy en 1872, y su aplicación industrial en la producción de leche y detergentes comenzó en la década de 1920. El secado spray es un proceso único en el que las partículas se forman al mismo tiempo que se secan (Barbosa Canovas y col. 2005). En dicho proceso, los productos deshidratados en 
polvo se producen a partir de una suspensión liquida, atomizando el producto húmedo a alta velocidad y dirigiendo el rociado de gotas hacia un flujo de aire caliente. Las pequeñas gotas atomizadas tienen un superficie específica muy grande en forma de millones de gotitas de tamaño micrométrico $(10-200 \mu \mathrm{m})$, lo que resulta en un tiempo de secado muy corto cuando se exponen al aire caliente en una cámara de secado (Morgan y col., 2006; Santivarangkna y col., 2007). Las enzimas deshidratadas, detergentes, extractos de café y proteínas aisladas son ejemplos de productos generados por secado por pulverización. Este proceso también se ha utilizado en la producción de cultivos de bacterias lácticas y bacterias probióticas deshidratadas (Barbosa Canovas y col., 1996; Riveros y col., 2009).

El proceso de secado spray se puede dividir en varias etapas (Figura 1). En primer lugar, la suspensión líquida es bombeada hacia una tobera de dos fluidos (2), en donde se atomiza al entrar en contacto con un gas a alta presión (1). La suspensión atomizada en pequeñas gotas entra en contacto con un gas (aire) previamente calentado (3) en la cámara de secado (4). Aquí, se pueden aplicar tres patrones de flujo de pulverización dependiendo de la dirección en la que el aire caliente y el líquido entran en la cámara de secado: co-corriente, contracorriente y flujo mixto. Como los probióticos son organismos sensibles al calor, es importante aplicar la configuración de co-corriente. En este patrón, las gotas más húmedas entran en contacto con la temperatura más alta y las partículas más secas con la más baja temperatura, minimizando así el riesgo de daño por calor a los microorganismos. Luego, las gotas se secan y se forman las partículas secas. Finalmente, las partículas sólidas se separan del aire de secado. En general, las partículas gruesas y pesadas se separan en la base de la cámara de secado por fuerza gravitacional (5) y las partículas finas se separan usando ciclones (6) y filtros de bolsa (7). El polvo recogido en el recipiente recolector es un polvo listo para usar (Masters, 1991). 


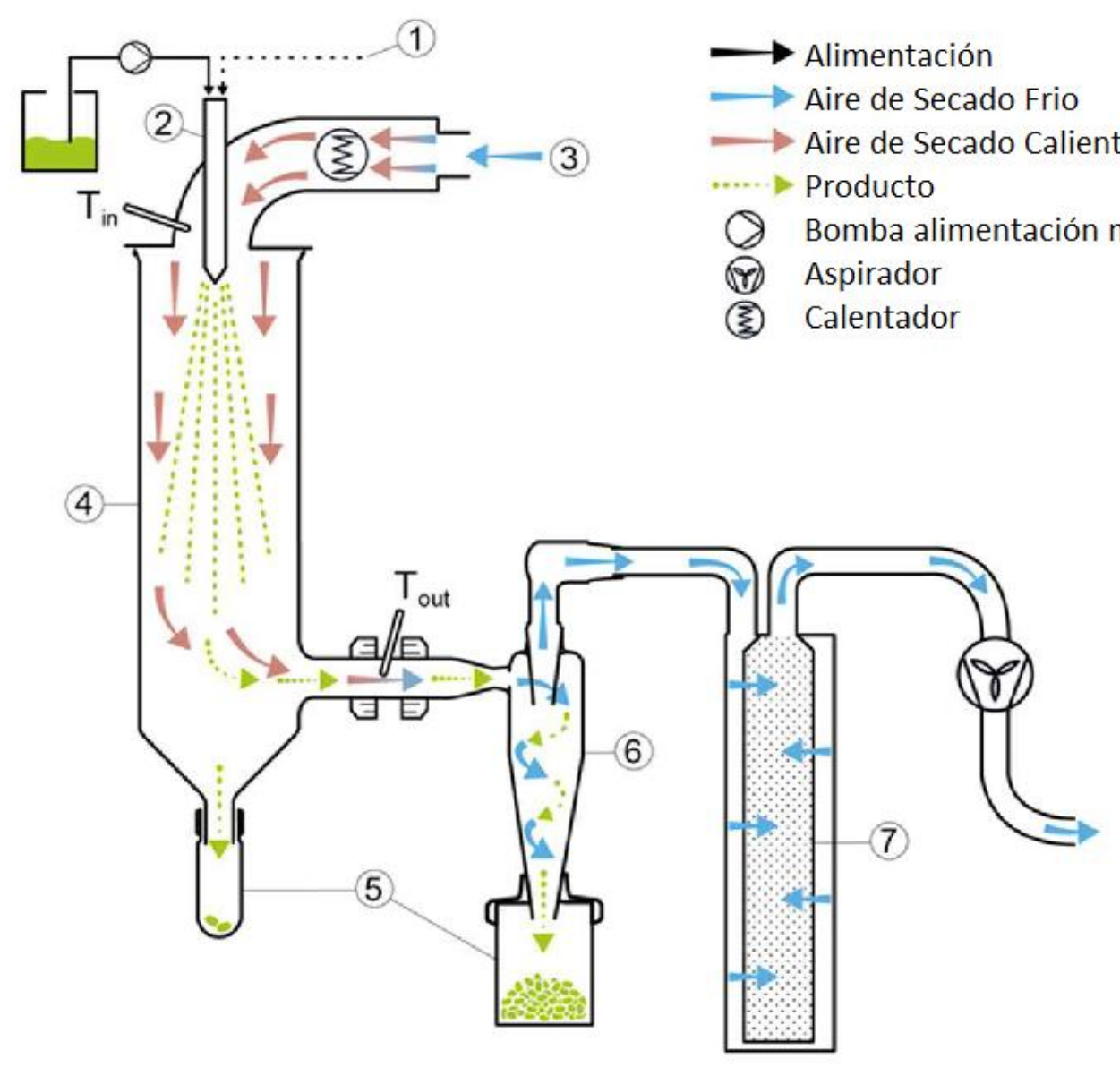

Figura 1: Esquema de funcionamiento de un secador spray de funcionamiento co-corriente. Adaptado de Buchi Application Note 248/2017 (2017).

La formación de las partículas secas es un proceso que también se da por etapas. Primero, se alcanza un equilibrio entre las pequeñas gotas del spray y el aire de secado. Después del contacto con el aire caliente, el agua comienza a evaporarse inmediatamente. Como la saturación en la superficie de la gota se puede mantener, esta evaporación es caracterizada en primer lugar por un período de secado a velocidad constante, donde la temperatura de las partículas está definida por la temperatura de bulbo húmedo. Una vez que las condiciones de saturación en la superficie de la gota ya no se puede mantener, comienza el segundo período de secado con la caída la velocidad de secado. A medida que la gota se encoge, se 
forma una corteza por cristalización de materiales disueltos o suspendidos en la suspensión de alimentación. La tasa de evaporación después de la formación de la corteza depende de la difusión de la humedad a través de la corteza seca. Con el aumento de la evaporación, la corteza se volverá más gruesa y la velocidad de evaporación será más lenta. La temperatura del producto aumentará y se asemejará a la temperatura del aire de secado. Es en esta última etapa donde los microorganismos son propensos a la inactivación por calor (Golman y Julklang, 2013; Masters, 1991; Peighambardoust y col., 2011).

Diversos investigadores coinciden en que el secado spray parece proporcionar grandes ventajas en comparación con otras técnicas de secado ya que es un proceso rápido, continuo y económico que puede procesar grandes cantidades de suspensiones líquidas en un tiempo relativamente corto. Además, el escalado del secado spray es más económico lo cual está en relación con la infraestructura y los equipos requeridos así como también con el tiempo del proceso.

Sin embargo, durante el secado spray las células se encuentran diferentes tipos de estrés (estrés térmico, deshidratación, esfuerzo cortante, estrés osmótico y estrés oxidativo) que pueden perjudicar su viabilidad. De todos ellos, se cree que el estrés por calor y la deshidratación son los dos mecanismos principales que conducen a la inactivación y pérdida de viabilidad de los microorganismos (Janning y in’t Veld, 1994; Perdana y col., 2013).

El estrés por calor hace referencia al hecho que las partículas secas permanecen en el equipo hasta el final del ciclo, éstas se pueden calentar a la temperatura de salida, haciendo de este un parámetro de influencia crítica en la viabilidad (Behboudi-Jobbehdar y col., 2013; Ghandi y col., 2012). Las temperaturas elevadas pueden provocar desnaturalización de las proteínas y desestabilizar las membranas conduciendo así a una pérdida de la viabilidad microbiana. Es importante tener en cuenta que el contenido de humedad y la actividad del agua (aW) del 
producto obtenido están ligados a la temperatura de salida. La aW juega un papel importante durante el almacenamiento de probióticos. Mayores temperaturas dan como resultado aW bajas, lo que se traduce, por lo general, en un aumento de la estabilidad durante el almacenamiento (Mathlouthi, 2001). Por lo tanto, es importante encontrar una temperatura de salida óptima, lo suficientemente alta para obtener una aW baja para mayor estabilidad, pero no demasiado alta para evitar un daño celular letal.

La deshidratación, como explican Ananta y col. (2005), se relaciona con la remoción de moléculas de agua de las células y su entorno, limitando así las reacciones químicas y la actividad metabólica. La eliminación de estas moléculas de agua tendrá implicaciones fisiológicas en la integridad celular y su estructura, ya que la membrana se desestabilizara causando perdida de compuestos intracelulares y, posiblemente, causando la muerte celular.

Si bien diversos factores de estrés pueden impactar mucho en la supervivencia de los probióticos durante y después del secado por pulverización, la mayoría de estos factores pueden ser superados por la selección racional de estrategias de protección y variables del proceso adecuadas.

Se pueden distinguir varias estrategias de protecciones principales: la adición de agentes protectores, la adaptación de los parámetros del proceso y el prestress de las bacterias antes del secado. Estas estrategias no sólo afectan la viabilidad de los microorganismos durante el proceso sino también durante el almacenamiento. Otra estrategia muy empleada es el aumento de los sólidos totales en la muestra, cuya implementación es sencilla y ciertos estudios han demostrado que un aumento de los sólidos disueltos hasta un $20 \% \mathrm{p} / \mathrm{v}$ ha resultado ser el óptimo para obtener una alta viabilidad de diversas cepas de bacterias lácticas tras el secado spray (Ananta y col., 2005). 
La adición de sacáridos, principalmente disacáridos, es otra de las estrategias más comúnmente aplicadas para proteger microorganismos durante el proceso de secado spray (Meng y col., 2008; Ying y col., 2012). Existen varias hipótesis en cuanto a cómo estos azúcares funcionan como termoprotectores, como la hipótesis de la vitrificación, la hipótesis del reemplazo de agua y la hipótesis de fuerzas de hidratación (Chen, 2019).

Para comprender esto, es necesario saber que en condiciones fisiológicas de hidratación normales, la bicapa lipídica de la membrana celular se encuentra en la fase fluida lamelar. Las colas de ácidos grasos se acomodan en el región hidrófoba de la bicapa, mientras que los grupos de cabeza polar se alinean con las moléculas de agua (Garvey y col., 2013). Durante la deshidratación esta bicapa puede sufrir una transición a fase gel, es decir, las colas lipídicas se presionan juntas en el plano de la membrana y los grupos de cabeza polar se acomodan más juntos, lo que puede causar que en la rehidratación no puedan volver a su conformación original, conduciendo a una posible fuga de componentes intracelulares y muerte celular (Bryant y col., 2007). Los sacáridos pueden prevenir la pérdida de integridad de la membrana por vitrificación (Grasmeijer y col., 2013). Al eliminar agua de la suspensión bacteriana los protectores en dicha suspensión se concentran, favoreciendo el estado vítreo sobre el estado gomoso de la matriz. En estado vítreo los procesos controlados por difusión y la movilidad se ralentizan considerablemente (Aschenbrenner y col., 2014; Bryant y col., 2007). Así, las bacterias probióticas inmersas en una matriz vítrea poseen mayor estabilidad química y física.

La hipótesis del reemplazo del agua establece que cuando el agua es reemplazada por los azúcares, los grupos polares de éstas pueden sustituir a los de las moléculas de agua. Los grupos de cabeza polar de la bicapa pueden directamente interactuar con los residuos $\mathrm{OH}$ del azúcar por puentes de hidrógeno. Como queda suficiente espacio entre los grupos de cabeza polar de los fosfolípidos de membrana durante la deshidratación, la integridad de la 
membrana se puede mantener durante la posterior rehidratación (Bryant y col., 2007; Clegg y col., 1982; Garvey y col., 2013; Golovina y col., 2009).

En contraste con la hipótesis del reemplazo del agua, la hipótesis de exclusión también se propone con frecuencia en la literatura. Ésta describe que la adición de azúcares estabiliza la fase con el área más pequeña. La eliminación del agua hace que la célula se contraiga, reduciendo el volumen celular y acercando las bicapas. Así, la fase de gel se favorece sobre la fase fluida (Aschenbrenner y col., 2014; Garvey y col., 2013; Golovina y col., 2009; Grasmeijer y col., 2013). Los azúcares son preferentemente separado de los grupos de cabeza polar de los fosfolípidos, aumentando la energía libre de la interfase y por lo tanto promoviendo las fases gel.

Andersen y col. (2011) concilian estas aparentes opiniones opuestas sobre interacción membrana-azúcar destacando que los efectos son dependientes de la concentración. A bajas concentraciones de azúcar, es predominante la interacción directa con las cabezas polares (hipótesis de reemplazo de agua), mientras que a mayores concentraciones de azúcar $(>0.2$ M) se favorece el mecanismo propuesto por la teoría de la exclusión A pesar de que diferentes mecanismos moleculares apoyan estas explicaciones, no se excluyen entre sí. Para la estabilización óptima de membrana y proteínas es probable que todos estos mecanismos estén contribuyendo.

Se observan respuestas de viabilidad variables de las bacterias lácticas cuando se utilizan diferentes solutos. La trehalosa, por ejemplo, ejerce efectos positivos sobre la viabilidad de diferentes cepas de L. plantarum (Lapsiri y col., 2012; Perdana y col., 2014). También algunos prebióticos como inulina (Ávila-Reyes y col., 2014) y fructo-oligosacáridos (Golowczyc y col., 2011) pueden influir positivamente en la viabilidad después de secado por pulverización y durante el almacenamiento de varias cepas de Lactobacillus. 
Ingredientes como el extracto de levadura (Jantzen y col., 2013), dextrano (Leja y col., 2009) y polidextrosa (Corcoran y col., 2004) también fueron evaluados por su efecto protector durante el secado spray.

Otro componente que ha sido examinado por su efecto protector sobre los probióticos durante el secado y el almacenamiento es el glutamato monosódico. La adición de este compuesto mostró un efecto positivo significativo sobre la viabilidad de Lactobacillus rhamnosus y L. sakei después del secado spray (Ferreira y col., 2005; Sunny-Roberts y Knorr, 2009). Algunos autores indican que la presencia de maltodextrina o la leche descremada reconstituida tienen un efecto protector sobre la viabilidad bacteriana después del secado (Golowczyc y col., 2010; Simpson y col., 2005). El mecanismo subyacente en el efecto protector de la leche descremada aún no está claro, ya que es un medio complejo que contiene lactosa, grasa, caseína, proteína de suero y cationes como el $\mathrm{Ca}^{2+}$. En un estudio reciente, el efecto protector de la leche descremada fue atribuido a la presencia de calcio y proteínas de la leche en lugar de a la presencia de lactosa (Zheng y col., 2015). En efecto, Huang y Chen (2013) ya habían demostrado que el $\mathrm{Ca}^{2+}$ juega un papel en la mejora de la resistencia al calor de las bacterias del ácido láctico. Aunque las proteínas del suero mejoran la viabilidad después del secado, los mecanismos subyacentes aún están bajo debate (Khem y col., 2015; Soukoulis y col., 2014). Esto indica que también otros iones y proteínas podrían ser utilizados como medidas de protección.

\subsubsection{Almacenamiento}

Desde un punto de vista comercial, es importante mantener la estabilidad de los productos secados por spray durante el mayor tiempo posible conservando sus características. La temperatura de almacenamiento, el contenido de humedad, la actividad del agua, la humedad relativa, la presencia de oxígeno y la exposición a la luz, entre otros, son factores que pueden influir en la vida útil del producto terminado. 
La influencia de la temperatura de almacenamiento en la viabilidad de los probióticos es bien conocida: a mayor temperatura, menores tasas de supervivencia a través del tiempo. Como ya han reportado varios autores, generalmente, durante el almacenamiento a temperaturas de refrigeración se obtiene la mejor estabilidad (Lapsiri y col., 2012; Meng y col., 2008; Schuck y col., 2013; Silva y col., 2002). Con respecto a la humedad, no hay un consenso en cuanto a los valores óptimos que debe tener el producto, sin embargo se sabe que un contenido de humedad cercano al $5 \%$ y una actividad de agua menor a 0,3 evita las reacciones de deterioro durante el almacenamiento (Behboudi-Jobbehdar y col., 2013; Dianawati y col., 2013; Shokri y col., 2015; Vesterlund y col., 2012; Ying y col., 2012). Por encima de este valor de aW comienzan las reacciones químicas que necesitan una fase acuosa (reacciones enzimáticas, crecimiento microbiano y fúngico). $\mathrm{Y}$ a valores inferiores, la tasa

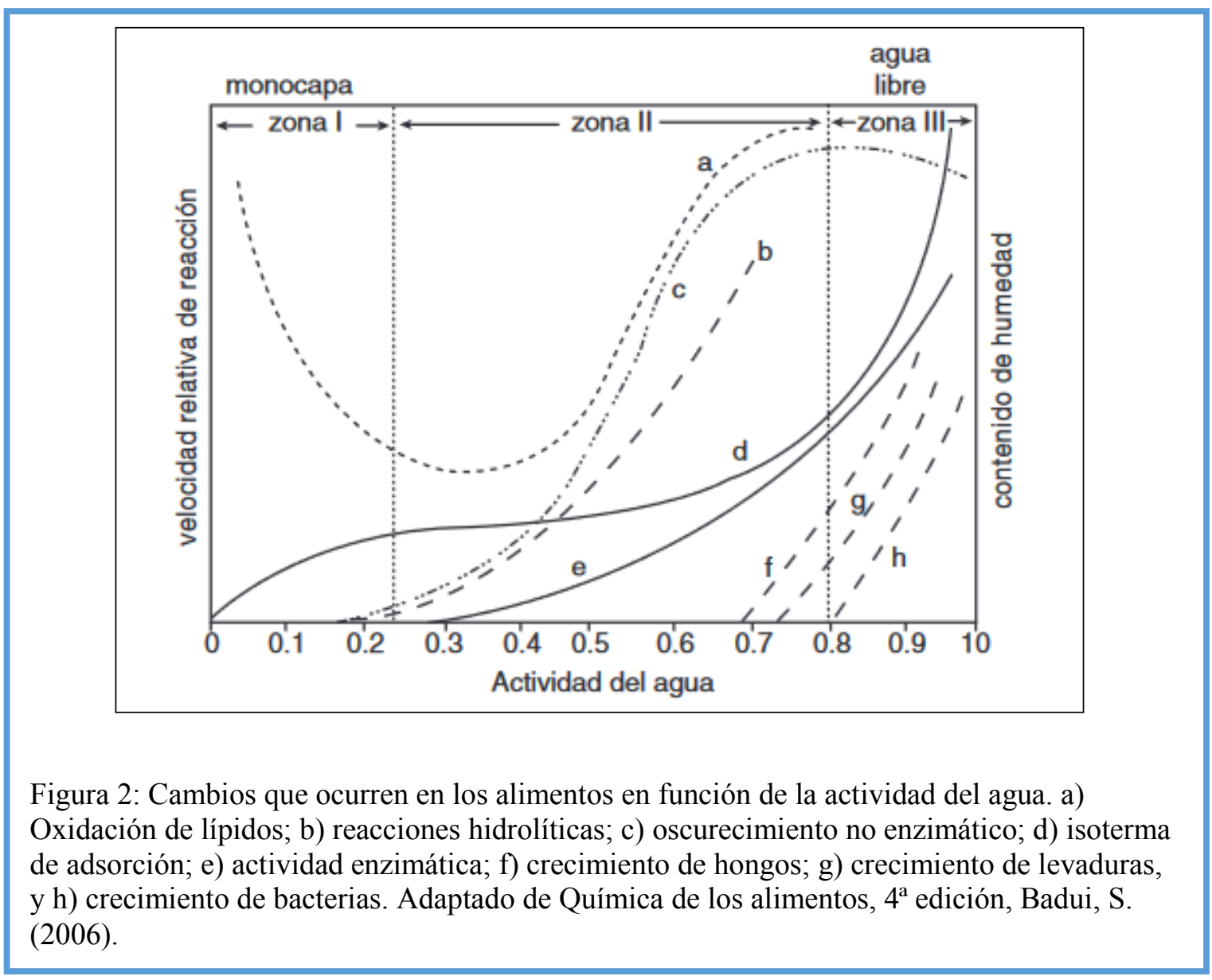


de oxidación lipídica aumenta, comprometiendo las características organolépticas del producto (Figura 2).

La importancia de obtener productos deshidratados con una actividad del agua y un contenido de humedad finales bajos y constantes está relacionada con la transición de fase vítrea / gomosa que puede ocurrir durante el almacenamiento. Una alta actividad de agua y contenido de humedad resultan en una disminución de la temperatura de transición vítrea. Si la temperatura de almacenamiento es superior a la temperatura de transición vítrea, el producto cambia de un estado vítreo a un estado gomoso, y la movilidad de las moléculas y la velocidad de las reacciones químicas están menos restringidas. El aumento de la movilidad molecular desestabiliza el material biológico y cambia las características del producto deshidratado (p. ej., fluidez, cristalinidad) conduciendo a una pérdida de viabilidad de los microorganismos probióticos y a una disminución de la vida útil del producto almacenado (Ghandi y col., 2012; Schutyser y col., 2012; Ying y col., 2010).

El creciente interés en los microorganismos probióticos y sus beneficios para la salud llevan a buscar nuevas presentaciones de estos productos que permitan masificar su consumo, y la deshidratación por secado spray se considera como una alternativa para crear productos probióticos a gran escala. Los métodos de producción de polvos probióticos secos deben ser tales que la viabilidad se mantenga en los productos deshidratados después de la fabricación y durante el almacenamiento para asegurar que se pueda suministrar una cantidad adecuada de microorganismos en el producto final. Siendo el kefir un alimento probiótico ampliamente estudiado en nuestro grupo de investigación, resulto de interés investigar la aplicación del secado spray al kefir y la caracterización del producto final obtenido y durante su almacenamiento para buscar nuevas presentaciones de este producto que permitan facilitar su almacenamiento y favorecer su distribución y consumo. 


\subsection{OBJETIVOS}

Teniendo en cuenta lo expuesto durante la Introducción, se establecieron los siguientes objetivos específicos para la primer parte de este trabajo de tesis:

- Establecer y optimizar las condiciones de deshidratación de kefir obtenido por fermentación de leche y/o permeado de suero mediante secado spray.

- Optimizar tanto el proceso de deshidratación como las características del producto mediante el uso de diferentes carriers.

- Evaluar el comportamiento de los productos deshidratados obtenidos durante la simulación del pasaje a través del tracto gastrointestinal.

- Estudiar la capacidad acidificante y la capacidad de inhibición del crecimiento de Salmonella por parte de los productos deshidratados obtenidos.

- Identificar las especies microbianas que prevalecen en el producto deshidratado elaborado en distintas condiciones.

- Monitorear el comportamiento de los distintos productos deshidratados respecto a su viabilidad microbiana y su actividad de agua durante el almacenamiento.

- Realizar un escalado del proceso a escala piloto, evaluando nuevos componentes de carriers, caracterizando productos obtenidos y estudiando su comportamiento durante el almacenamiento. 


\subsection{MATERIALES Y MÉTODOS}

\subsubsection{Cultivo de kefir}

Se realizó en dos medios diferentes.

Leche UHT (modo tradicional): Gránulos activos AGK1 de la colección del CIDCA (Garrote, Abraham \& De Antoni 2001) fueron inoculados en leche UHT descremada comercial (Sancor, Santa Fe, Argentina) en una proporción del 10 \% p/v. Luego se incubó durante $24 \mathrm{~h}$ a $20{ }^{\circ} \mathrm{C}$ con objeto de obtener la leche fermentada. Luego de transcurrida la fermentación, los gránulos de kefir fueron separados del producto fermentado por filtración con un colador plástico previamente desinfectado con etanol $70 \%$.

Permeado de suero como sustrato: se utilizó el mismo procedimiento que el arriba descripto, pero usando una solución de permeado de suero (Arla Foods Ingredients S.A., BsAs, Argentina) al $20 \%$ p/v en lugar de leche UHT. La solución $20 \%$ fue esterilizada mediante autoclave (20 minutos a $121^{\circ} \mathrm{C}$ y 1 ATM de sobrepresión) previo a ser utilizada.

\subsubsection{Secado Spray}

\subsubsection{Escala laboratorio}

Para el secado en spray a escala laboratorio se utilizó un equipo BUCHI Mini Spray Dryer B-290, que posee un funcionamiento co-corriente (Figura 3) 


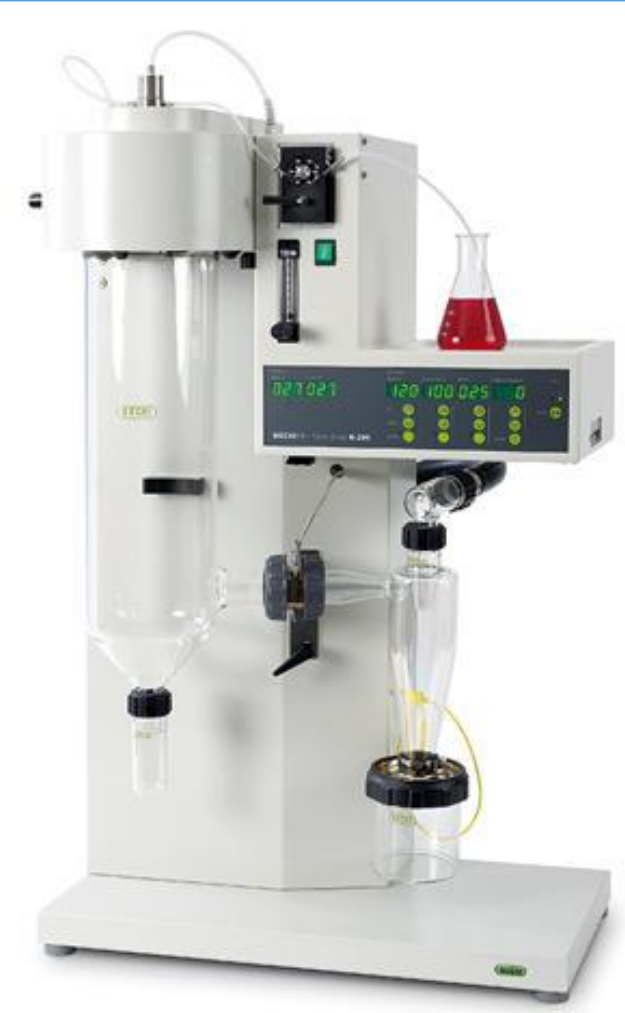

Figura 3: Fotografía del equipo para secado spray escala laboratorio utilizado para el presente trabajo de tesis. Buchi Mini Spraydryer B-290.

\subsection{Elección de parámetros óptimos de secado:}

El kefir obtenido de modo tradicional (Ver 1.3.1) fue sometido a secado spray variando la temperatura de aire de entrada y/o el caudal de alimentación de la muestra. Como el objetivo fue obtener un producto deshidratado con una vida útil prolongada, se estableció un valor de actividad de agua $(\mathrm{aW})$ de 0,3 como punto de corte. Debido a que la viabilidad microbiológica en el producto final está íntimamente relacionada con la temperatura de salida (T salida), se seleccionó como parámetro óptimo aquella combinación de temperatura de entrada y caudal de alimentación que permitiera obtener un producto con aW inferior a 0,3 a la menor temperatura de salida posible. 


\subsection{Procedimiento}

Las muestras se deshidrataron a una temperatura de entrada constante de $135^{\circ} \mathrm{C}$, un flujo de aire de 473 1/h y un flujo de alimentación de $10 \mathrm{ml} / \mathrm{min}$. Como resultado de esta elección de parámetros, la temperatura de salida de la muestra osciló entre los 66 y los $69^{\circ} \mathrm{C}$. Las suspensiones fueron atomizadas dentro de la cámara de secado usando una boquilla de dos fluidos.

Todas las muestras fueron estabilizadas a temperatura ambiente y homogeneizadas previo al procedimiento de secado spray. Los polvos obtenidos fueron almacenados en recipientes estériles, sellados herméticamente y protegidos de la luz.

\subsection{Secado spray directo}

El producto fermentado obtenido como se explicó (Ver 1.3.1), tanto en leche UHT como en permeado de suero $20 \% \mathrm{p} / \mathrm{v}$, fue secado en spray sin ningún otro tratamiento inmediatamente luego de finalizada la fermentación.

\subsection{Secado spray utilizando carriers}

El producto obtenido tras la fermentación de leche UHT con gránulos de kefir fue centrifugado a $11200 \mathrm{x}$ g durante 15 minutos. El sobrenadante fue descartado, y el pellet obtenido fue resuspendido en una solución estéril al $20 \%(\mathrm{p} / \mathrm{v})$ de los distintos carriers, los cuales se resumen en la Tabla 2. 
Tabla 2: Carriers utilizados para el secado spray de kefir. La nomenclatura utilizada para el carrier se conserva como nombre del producto obtenido con el mismo.

\begin{tabular}{|l|l|}
\hline MTR & Descripción \\
\hline SM & Leche descremada $20 \% \mathrm{p} / \mathrm{v}, \mathrm{pH}=5.85$ \\
\hline SMN & Leche descremada $20 \% \mathrm{p} / \mathrm{v}, \mathrm{pH}=7$ \\
\hline SMM & Leche descremada $20 \% \mathrm{p} / \mathrm{v}+$ Maltodextrina $20 \% \mathrm{p} / \mathrm{v}$, partes iguales, $\mathrm{pH}=5.78$ \\
\hline SMMN & Leche descremada $20 \% \mathrm{p} / \mathrm{v}+$ Maltodextrina $20 \% \mathrm{p} / \mathrm{v}$, partes iguales, $\mathrm{pH}=7$ \\
\hline WP & Permeado de suero $20 \% \mathrm{p} / \mathrm{v}, \mathrm{pH}=4.88$ \\
\hline WPN & Permeado de suero $20 \% \mathrm{p} / \mathrm{v}, \mathrm{pH}=7$ \\
\hline WPM & Permeado de suero $20 \% \mathrm{p} / \mathrm{v}+$ Maltodextrina $20 \% \mathrm{p} / \mathrm{v}$, partes iguales, $\mathrm{pH}=4.71$ \\
\hline WPMN & Permeado de suero $20 \% \mathrm{p} / \mathrm{v}+$ Maltodextrina $20 \% \mathrm{p} / \mathrm{v}$ partes iguales, $\mathrm{pH}=7$ \\
\hline MT & Maltodextrina $20 \% \mathrm{p} / \mathrm{v}+\mathrm{Trehalosa} 20 \% \mathrm{p} / \mathrm{v}$, partes iguales, $\mathrm{pH}=3.98$ \\
\hline WPT & Permeado de suero $20 \% \mathrm{p} / \mathrm{v}+$ Trehalosa $20 \% \mathrm{p} / \mathrm{v}$, partes iguales, $\mathrm{pH}=4.78$ \\
\hline SMT & Leche descremada $20 \% \mathrm{p} / \mathrm{v}+$ Trehalosa $20 \% \mathrm{p} / \mathrm{v}$, partes iguales, $\mathrm{pH}=5.55$ \\
\hline MTN & Maltodextrina $20 \% \mathrm{p} / \mathrm{v}+$ Trehalosa $20 \% \mathrm{p} / \mathrm{v}$, partes iguales, $\mathrm{pH}=7$ \\
\hline WPTN & Permeado de suero $20 \% \mathrm{p} / \mathrm{v}+$ Trehalosa $20 \% \mathrm{p} / \mathrm{v}$, partes iguales, $\mathrm{pH}=7$ \\
\hline SMTN & Leche descremada $20 \% \mathrm{p} / \mathrm{v}+$ Trehalosa $20 \% \mathrm{p} / \mathrm{v}$, partes iguales, $\mathrm{pH}=7$ \\
\hline
\end{tabular}




\subsubsection{Secado spray a escala piloto}

Para el secado spray a escala piloto se utilizó un equipo NIRO ATOMIZER (Copenague,

Dinamarca) (Figura 4). Todas las suspensiones fueron homogeneizadas y estabilizadas a temperatura ambiente antes de ser sometidas al proceso de deshidratación.

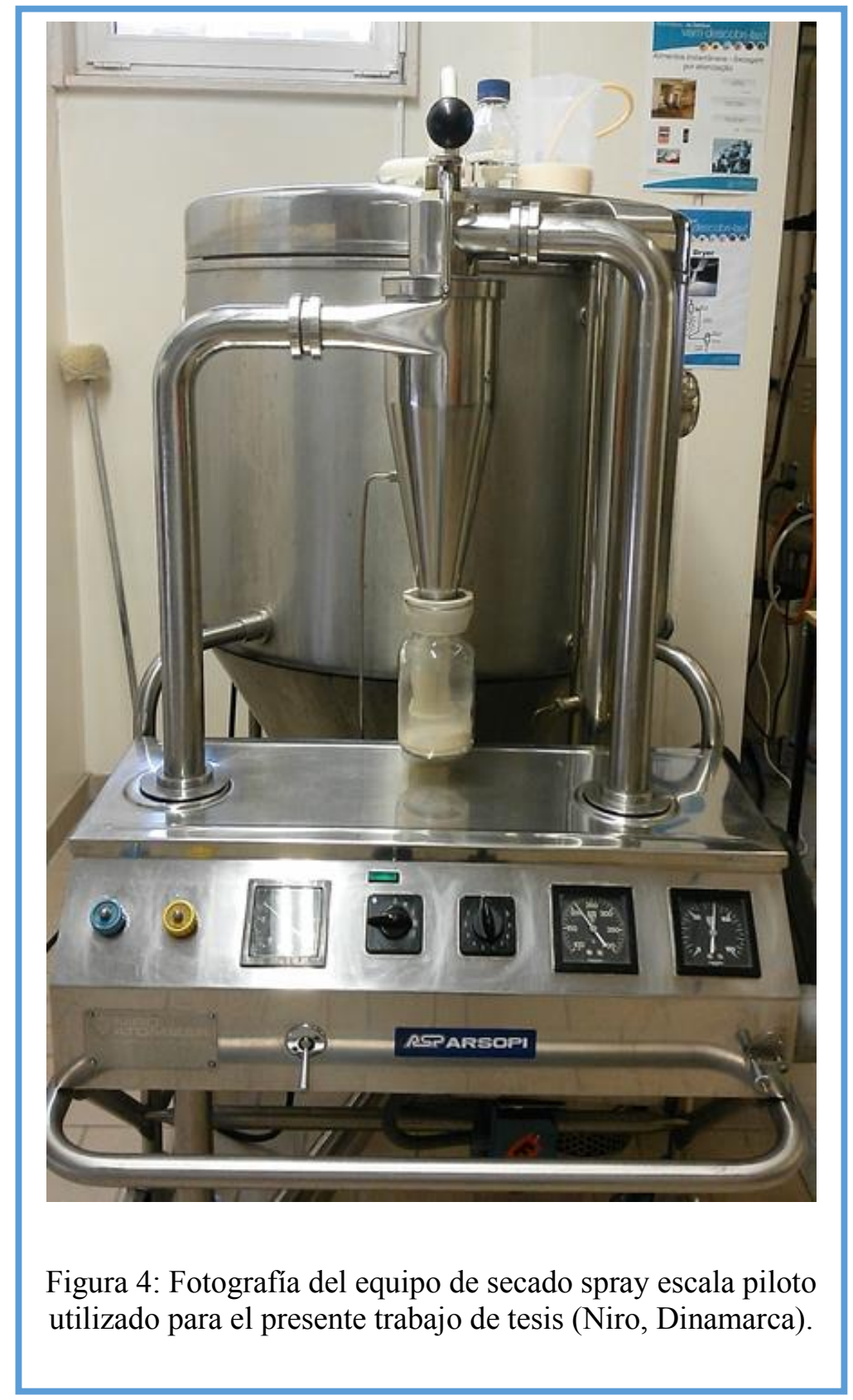

Para los experimentos realizados, la temperatura de entrada seleccionada fue de 200 o 210 ${ }^{\circ} \mathrm{C}$, la alimentación del equipo con la muestra fue constante a $20 \mathrm{ml} / \mathrm{min}$ y la presión de aire 
fue de 3 bar; resultando en temperaturas de salida de 75 y $80{ }^{\circ} \mathrm{C}$ para cada una de las temperaturas de entrada respectivamente.

El polvo obtenido se recolectó en bolsas de polietileno previamente esterilizadas por radiación y se envasó al vacío.

\subsubsection{Caracterización de los productos deshidratados}

\subsubsection{Rendimiento}

El rendimiento del proceso de secado spray (Y \%) fue definido en base a la relación entre la masa de sólidos recolectada al final del proceso y la masa de sólidos iniciales de la suspensión con la que se alimentó el equipo (feed solution). Se calculó entonces el rendimiento porcentual (Y \%) según la siguiente fórmula:

$\mathrm{Y} \%=(\mathrm{wf} / \mathrm{wi}) * 100$

Donde Y \% es el rendimiento porcentual, wf es el peso de los sólidos obtenidos luego del proceso y wi es el peso total de sólidos en la suspensión antes del secado.

El producto remanente en las paredes internas del ciclón no fue considerado como parte del rendimiento.

\subsubsection{Análisis microbiológico}

El número de bacterias lácticas y levaduras viables fue evaluado en cada etapa (leche fermentada, suspensión carrier y muestras de kefir en polvo reconstituidas) mediante recuento en placa. Previo al proceso de secado spray, $10 \mathrm{ml}$ de kefir obtenido como se indicó anteriormente o de suspensión carrier y $90 \mathrm{ml}$ de solución salina $(0.85 \% \mathrm{p} / \mathrm{v} \mathrm{NaCl})$, fueron homogeneizados durante $90 \mathrm{seg}$ en vortex. Las muestras en polvo, por su parte, se rehidrataron durante 30 min homogeneizando en vortex cada 3 min. Para los recuentos se realizaron diluciones seriadas y se sembraron placas de YGC (Biokar, France) para el recuento de las levaduras y en MRS (Difco, France) para el recuento de las bacterias lácticas. 
Las condiciones de incubación fueron de $48 \mathrm{~h}$ a $30{ }^{\circ} \mathrm{C}$ cuando se utilizó YGC y de 24 h a 37 ${ }^{\circ} \mathrm{C}$ cuando se utilizó MRS. Los recuentos se realizaron por triplicado para cada muestra en cada medio.

\subsubsection{Humedad y actividad de agua}

El contenido de humedad se calculó de acuerdo con el método AA-15A (Métodos de análisis aprobados, $11^{\mathrm{a}}$ ed.) de la Asociación Americana de Químicos de Cereales (St. Paul, EE. UU.), tal como fue descripto por Behboudi-Jobbehdar y colaboradores (Behboudi-Jobbehdar y col., 2013). Brevemente, se colocaron dos gramos del polvo en bandejas de aluminio y se secaron a $105^{\circ} \mathrm{C}$ durante 24 horas. El contenido de humedad residual se calculó de acuerdo con la fórmula:

$\%$ de humedad $=100 *($ wi-wf $) /$ wi;

Donde wi y wf son los pesos de las muestras antes y después de la deshidratación a $105^{\circ} \mathrm{C}$, respectivamente.

La actividad de agua de los polvos obtenidos (aW) fue medida luego del proceso de secado spray en un equipo Aqualab 4TEV (Decagon Devices, EEUU) mediante el método de punto de rocío a $25^{\circ} \mathrm{C}$. Las muestras se estabilizaron a temperatura ambiente antes de la medición. Para la calibración del equipo se utilizaron soluciones estándar provistas por el fabricante (Decagon, EEUU).

\subsubsection{Tamaño de partícula}

La distribución de tamaño de partícula se determinó mediante SLS (static light scatter dispersión de luz estática) empleando un equipo Malvern Mastersizer 2000E (Malvern Instruments, Reino Unido). Para realizar la medición en el equipo se agregó $1 \mathrm{ml}$ de muestra (gota a gota) a un vaso de precipitado con $600 \mathrm{ml}$ de agua en constante agitación a $2000 \mathrm{rpm}$ (Hydro 2000MU, Malvern Instruments, Reino Unido). La muestra utilizada para la 
medición consistió en una dilución $10 \%$ p/v en agua milliQ estéril de cada uno de los productos deshidratados.

\subsubsection{Capacidad acidificante}

Existen diversos métodos para evaluar la capacidad acidificante de un cultivo láctico starter o de un producto probiótico deshidratado. La mayoría de estos métodos se basan en que si los microorganismos presentes en el producto están activos conservan su capacidad de realizar procesos metabólicos. Así, para analizar la capacidad acidificante de los productos desarrollados nos basamos en la capacidad de las bacterias lácticas de acidificar el medio por fermentación de los azúcares de la leche. Para esta determinación se inocularon 10ml de leche UHT con $1 \mathrm{~g}$ de muestra deshidratada, se homogeneizó y se incubó a temperatura ambiente. Luego se analizó el descenso de pH a lo largo del tiempo comparado con la leche sin inocular (control).

\subsubsection{Inhibición del crecimiento de Salmonella}

Para evaluar la actividad antagónica contra un patógeno especifico como Salmonella, se realizó un ensayo de difusión en agar utilizando 3 diferentes cepas de Salmonella enterica serovar Enteritidis: SE105, SE106 y SE115. Para ello se realizó un hisopado en tres direcciones en la superficie de una placa de agar nutritivo con una suspensión de cada cepa Salmonella ajustada al 0,5 de la escala de McFarland. Esto equivale aproximadamente a $1,5 \times 10^{8} \mathrm{UFC} / \mathrm{ml}$ y permite generar un crecimiento en forma de pátina. Luego se realizaron huecos de 2,5 mm de diámetro en el agar en los cuales se colocaron con la muestra a analizar. Luego de $24 \mathrm{~h}$ de incubación a $37^{\circ} \mathrm{C}$, se midió el halo de inhibición originado en torno a la muestra.

Para este ensayo se utilizaron 3 diferentes cepas de Salmonella enterica serovar Enteritidis: SE105, SE106 y SE115 


\subsubsection{Resistencia al pasaje gastrointestinal}

La supervivencia de los microorganismos deshidratados a través de una simulación del pasaje gástrico, fue realizada de acuerdo a Grimoud (2010). Para ello, las muestras fueron suspendidas en $5 \mathrm{ml}$ de PBS estéril, y se tomó una alícuota de dicha suspensión para poder evaluar el número inicial de microorganismos para cada muestra. Luego se realizó una centrifugación y el pellet obtenido fue resuspendido en $5 \mathrm{ml}$ de solución gástrica GS, alcanzando una $\mathrm{OD}=0.5\left(1 \times 10^{8}\right.$ células $\left./ \mathrm{ml}\right)$. La solución gástrica consistió en 7,25 g/1 NaCl, 0,52 g/1 KCl, 3,8 g/L NaHCO 3 y 3,0 g/1 de pepsina porcina (Sigma-Aldrich), y se ajustó el $\mathrm{pH}$ a 2,5 con una solución $\mathrm{HCl} 36,5 \mathrm{~g} / \mathrm{l}$. Luego de una hora incubándose a $37{ }^{\circ} \mathrm{C}$ con agitación, se tomaron muestras para realizar recuento microbiológico. Transcurrida la simulación gástrica., se realizó un lavado con PBS estéril y se resuspendió la muestra en 5 $\mathrm{ml}$ de solución intestinal. La solución intestinal (IS) se formuló como 1,3 g/1 NaCl, 0,25 g/1 $\mathrm{KCl}, 0,65 \mathrm{~g} / 1 \mathrm{NaHCO}_{3}, 1,0 \mathrm{~g} / 1$, pancreatina porcina (Sigma-Aldrich) y 1,5 g/1 sales biliares (Sigma-Aldrich). El pH se ajustó luego a 8 con una solución de $\mathrm{NaOH} 200$ g/l. Luego de 3 horas de incubación a $37{ }^{\circ} \mathrm{C}$ se tomó una muestra para el recuento final. Todas las centrifugaciones se realizaron a $8000 \mathrm{x}$ g por 10 minutos.

\subsubsection{Selección de colonias más prevalentes en los productos e identificación por} secuenciación del gen de ARNr $16 \mathrm{~S}$

Las distintas colonias de bacterias lácticas observadas en los recuentos microbiológicos se aislaron y se clasificaron de acuerdo a su muestra de procedencia, sus características macroscópicas y microscópicas. Finalmente, aquellas que poseían diferentes características en la morfología de sus colonias, fueron sometidas a una extracción de ADN para luego proceder a su identificación por secuenciación de la región que codifica para el ARNr 16S. 
Para la extracción de ADN, $1 \mathrm{ml}$ de cultivo en medio líquido crecido durante $16 \mathrm{~h}$ a $37^{\circ} \mathrm{C}$ se centrifugó a 11200 x g durante 1 min. Se descartó el sobrenadante y el pellet obtenido se lavó (resuspendido y centrifugado) 3 veces con $200 \mu$ de PBS. Una vez lavado, el pellet se resuspendió en $10 \mu \mathrm{l}$ de Proteinasa K $20 \mathrm{mg} / \mathrm{ml}$ y $190 \mu \mathrm{l}$ de buffer de lisis y se incubó durante 20 min a $37^{\circ} \mathrm{C}$. Una vez transcurrido el tiempo de incubación, se centrifugó a 11200 x g durante 1 min, y el sobrenadante obtenido se resuspendió en $200 \mu \mathrm{l}$ de buffer de lisis y 0,5 gramos de microesferas de vidrio para realizar un lisado mecánico de las células. Luego se agitó en vortex durante 15 min y se centrifugó a 11200 x g durante 2 min. El sobrenadante obtenido contiene el material genético extraído de las células.

Para purificar el ADN presente en este sobrenadante se utilizaron columnas QIAmp de purificación de DNA (QIAgen, EEUU), siguiendo las instrucciones del fabricante. La cantidad de ADN presente en la muestra y la pureza del mismo se determinó utilizando un NanoDROP (Thermofisher, EEUU)

El ADN obtenido fue enviado a MRDNA Labs. (Texas, EEUU) para su secuenciación e identificación.

\subsubsection{Cuantificación de ácidos orgánicos por HPLC}

La cuantificación de ácidos orgánicos en los productos obtenidos a escala piloto, se realizó mediante cromatografía líquida de alta presión (HPLC). Para ello, 1 g de los productos deshidratados se diluyó en $10 \mathrm{ml}$ de agua milliQ estéril, y luego estas suspensiones obtenidas fueron filtradas utilizando filtros de membrana de $0,22 \mu \mathrm{m}$ antes de ser sometidas al análisis.

Para la separación se utilizó una columna de intercambio iónico Aminex HPX-87H de 300 x 7,8 mm (Bio-RAD, EEUU). En este tipo de columna, la retención se basa en la atracción electrostática entre los iones en solución y las cargas inmovilizadas a la fase estacionaria. Se midió el tiempo de retención de cada ácido en comparación con los tiempos de retención de 
soluciones standard de ácidos. Los ácidos orgánicos fueron detectados con un detector de índice de refracción KNAUER K-2301 (Knauer, Alemania.). La fase móvil consistió en una solución de ácido sulfúrico $2,5 \mathrm{mM}$, y se utilizó un flujo de $0,6 \mathrm{ml} / \mathrm{min}$ y una temperatura de $40{ }^{\circ} \mathrm{C}$. El volumen de muestra inyectado en el equipo fue de $20 \mu \mathrm{l}$ y la inyección se realizó con un inyector automático Knauer K-1001 (Knauer, Alemania). Se realizaron curvas de calibración con ácidos acético y láctico de grado HPLC (Sigma-Aldrich, EEUU). El tiempo de retención se obtuvo a partir de un cromatograma realizado con soluciones patrón.

\subsubsection{Almacenamiento}

Para productos obtenidos a escala laboratorio, las muestras obtenidas fueron almacenadas 90 días a $4{ }^{\circ} \mathrm{C}$ sin control de la humedad relativa, a resguardo de la luz y selladas herméticamente. A diferentes intervalos de tiempo se tomaron muestras para determinar la viabilidad por recuento en placa, la aW y la capacidad acidificante de las muestras. Para los recuentos microbiológicos, $1 \mathrm{~g}$ de polvo fue rehidratado en $10 \mathrm{ml}$ de solución salina $(0,85 \%$ $\mathrm{p} / \mathrm{v} \mathrm{NaCl}$ ), homogeneizado durante un minuto en vortex. Las suspensiones de dejaron a temperatura ambiente durante 30 min realizando homogenizaciones con vortex cada $3 \mathrm{~min}$ y previo a la toma de muestra. Luego se realizaron diluciones seriadas y se plaqueó en MRS agar. Los recuentos se determinaron luego de $48 \mathrm{~h}$ de incubación a $37^{\circ} \mathrm{C}$.

Para los productos obtenidos a escala piloto, las muestras obtenidas fueron almacenadas al vacío en bolsas de polietileno previamente esterilizadas por radiación UV a $4{ }^{\circ} \mathrm{C}$ y $20{ }^{\circ} \mathrm{C} \mathrm{y}$ al resguardo de la luz. A diferentes intervalos de tiempo se tomaron muestras de cada producto para determinar la viabilidad microbiológica y la aW de los mismos. Para ello se procedió del mismo modo que con las muestras obtenidas a escala laboratorio. 


\subsubsection{Análisis estadístico}

Todos los experimentos fueron realizados por triplicado utilizando al menos tres muestras independientes de kefir. Las diferencias relativas fueron reproducibles independientemente del cultivo utilizado. El análisis de la varianza (ANOVA) de los recuentos de viables correspondientes a los diversos tratamientos se realizó usando el programa estadístico Statgraphics Centurion XVII (Statistical Graphics Corp, EEUU). Se realizó la comparación de medias por el método de Tukey, considerando como estadísticamente significativa la diferencia cuando $p<0.05$.

Los gráficos fueron realizados utilizando el software GraphPad Prism 6 (GraphPad Software, EEUU), excepto para los gráficos de análisis multivariantes que se realizaron con el software Infostat (Grupo InfoStat, FCA, Universidad Nacional de Córdoba, Argentina). 


\subsection{RESULTADOS Y DISCUSIÓN}

\subsubsection{Elección de las condiciones de secado}

Para obtener los parámetros óptimos de secado spray, se procedió a secar la leche fermentada obtenida por fermentación de leche UHT con gránulos de kefir AGK1 en diferentes condiciones. Según se mencionó en la introducción, el objetivo es la obtención de un producto deshidratado que contenga un valor adecuado de microorganismos viables y una actividad de agua menor que 0,3 , para poder asegurar un mejor comportamiento durante el almacenamiento. Se utilizaron dos parámetros para evaluar los productos obtenidos en las diferentes condiciones: la supervivencia de bacterias lácticas y la actividad de agua (aW).

El equipo de secado spray utilizado a escala laboratorio (Buchi b-290) permite establecer los siguientes parámetros: temperatura del aire de entrada (Temperatura entrada), flujo de gas en la boquilla (air flow), caudal de alimentación de muestra liquida (feed) y flujo de aire de secado (aspirator).

La temperatura de salida, es la temperatura a la que es más probable que las células se acerquen al final del proceso de secado, es aquel parámetro con mayor influencia en la perdida de viabilidad. Esta temperatura no se puede controlar individualmente ya que depende principalmente de la temperatura de entrada y la velocidad de alimentación, y en menor medida de la composición del medio y tamaño de gota atomizada (Boza y col., 2004; Santivarangkna, y col. 2007, 2008). Sin embargo, los ajustes adecuados para estas variables son difíciles de calcular de antemano, y esto puede llevar a una gran variación en la viabilidad del cultivo deshidratado (Roelans y Taeymans, 1990).

Al utilizar velocidades de alimentación más altas, se necesita evaporar más líquido por unidad de tiempo, y el contenido de humedad en la fase gaseosa circundante aumentará. Esto resulta en una temperatura de salida más baja, obteniéndose así mayor viabilidad del 
probiótico en el producto deshidratado. Sin embargo, cuanto mayor sea el contenido de humedad del gas circundante, mayor será la posibilidad de obtener un producto húmedo, lo que podría ser perjudicial para el almacenamiento a largo plazo y para la suspensión al momento de su utilización.

Los productos deshidratados obtenidos por secado spray a una temperatura de salida más baja tienen un mayor contenido de humedad y mayor viabilidad que aquellos obtenidos a partir de temperaturas de salida más altas. La relación entre viabilidad de bacterias lácticas luego del secado spray y temperatura de salida del proceso ya ha sido reportada por diversos investigadores, como Golowczyc y col. (2010), quienes encontraron una mejora en la viabilidad al disminuir la temperatura salida de 85 a $70{ }^{\circ} \mathrm{C}$ y Romano y col. (2014) que obtuvieron las mejores tasas de supervivencia para dos cepas de L. rhamnosus cuando la temperatura de salida fue de $65{ }^{\circ} \mathrm{C}$. Teniendo en cuenta estos antecedentes, se estableció como parámetro arbitrario para el proceso de secado una temperatura de salida inferior a 75 ${ }^{\circ} \mathrm{C}$ (que se traduciría en una menor pérdida de la viabilidad).

Los parámetros seleccionados para la búsqueda de las condiciones óptimas de secado fueron la temperatura de entrada y la velocidad de alimentación de la muestra. El parámetro aspirator se mantuvo constante $\left(100 \%\right.$, aproximadamente $\left.30 \mathrm{~m}^{3} / \mathrm{h}\right)$ para asegurar una buena separación de partículas en el ciclón, y el air flow también se mantuvo constante y lo suficientemente alto $(473 \mathrm{l} / \mathrm{h})$ como para asegurar una correcta atomización en la tobera.

Así, la temperatura de entrada se varió entre 120 y $160^{\circ} \mathrm{C}$ para tres valores de caudal de alimentación ( bacterias lácticas y la aW del producto deshidratado obtenido (Tabla 3). 
Tabla 3: Valores de actividad de agua y recuentos de bacterias lácticas viables en MRS para kefir elaborado del modo tradicional deshidratado en distintas condiciones. Los valores resumidos en la tabla muestran los resultados de por lo menos tres experimentos independientes.

\begin{tabular}{|c|c|c|c|c|c|c|c|c|c|c|c|}
\hline \multicolumn{4}{|c|}{ Velocidad bomba de alimentación (pump): 20 \% } & \multicolumn{4}{|c|}{ Velocidad bomba de alimentación (pump): 30 \% } & \multicolumn{4}{|c|}{ Velocidad bomba de alimentación (pump): 40 \% } \\
\hline $\begin{array}{l}\text { Temperatura } \\
\text { Entrada }\left({ }^{\circ} \mathrm{C}\right)\end{array}$ & $\begin{array}{l}\text { Temperatura } \\
\text { Salida }\left({ }^{\circ} \mathrm{C}\right)\end{array}$ & $\begin{array}{l}\text { Bacterias } \\
\text { Lácticas } \\
\text { (log UFC/g) }\end{array}$ & aW & $\begin{array}{l}\text { Temperatura } \\
\text { Entrada }\left({ }^{\circ} \mathrm{C}\right)\end{array}$ & $\begin{array}{c}\text { Temperatura } \\
\text { Salida }\left({ }^{\circ} \mathrm{C}\right)\end{array}$ & $\begin{array}{l}\text { Bacterias } \\
\text { Lácticas } \\
(\log \text { UFC/g) }\end{array}$ & $\mathrm{aW}$ & $\begin{array}{l}\text { Temperatura } \\
\text { Entrada }\left({ }^{\circ} \mathrm{C}\right)\end{array}$ & $\begin{array}{l}\text { Temperatura } \\
\text { Salida }\left({ }^{\circ} \mathrm{C}\right)\end{array}$ & $\begin{array}{l}\text { Bacterias } \\
\text { Lácticas } \\
\text { (log } \\
\text { UFC/g) }\end{array}$ & $\mathrm{aW}$ \\
\hline 120 & 64 & 5,6 & 0,3 & 120 & ND & ND & ND & 120 & ND & ND & ND \\
\hline 125 & 68 & 5,4 & 0,28 & 125 & ND & ND & ND & 125 & ND & ND & ND \\
\hline 130 & 74 & 5,1 & 0,22 & 130 & 62 & 5,8 & 0,37 & 130 & ND & ND & ND \\
\hline 135 & 77 & 4,9 & 0,21 & 135 & 67 & 5,8 & 0,28 & 135 & ND & ND & ND \\
\hline 140 & 81 & 4,8 & 0,19 & 140 & 76 & 5 & 0,21 & 140 & 66 & 5,7 & 0,44 \\
\hline 145 & 86 & 4,7 & 0,18 & 145 & 80 & 4,6 & 0,19 & 145 & 74 & 5,7 & 0,42 \\
\hline 150 & 90 & 4,5 & 0,19 & 150 & 83 & 4,4 & 0,18 & 150 & 79 & 5,4 & 0,37 \\
\hline 160 & 93 & 3,9 & 0,17 & 160 & 87 & 3,9 & 0,17 & 155 & 83 & 5,1 & 0,34 \\
\hline 165 & 95 & 3,7 & 0,17 & 165 & 89 & 3,8 & 0,18 & 160 & 86 & 4,9 & 0,31 \\
\hline
\end{tabular}

ND: No Determinado 
Según los resultados observados en la Tabla 3, una alimentación del $30 \%$ y una temperatura de entrada de $135{ }^{\circ} \mathrm{C}$ resultó ser la mejor combinación de parámetros, ya que se logró maximizar la supervivencia de bacterias lácticas $(5,8 \log \mathrm{UFC} / \mathrm{g})$ y obtener una actividad de agua $(\mathrm{aW})$ menor a 0,3 en el producto deshidratado.

Se observó también que el proceso de secado no fue exitoso cuando se utilizó un caudal de alimentación de $40 \%$ a temperaturas de entrada menores a $140{ }^{\circ} \mathrm{C}$. Probablemente, la muestra ingresó muy rápido al equipo y no logró secarse, quedando adherida a la cámara de secado. Esto mismo se observó cuando la alimentación fue del $30 \%$, pero sólo a temperaturas menores a $130{ }^{\circ} \mathrm{C}$. Las muestras secadas con feed $40 \%$ mostraron una alta supervivencia de bacterias lácticas (aprox. $5 \log \mathrm{UFC} / \mathrm{g}$ ), pero su actividad de agua fue superior a 0,3 .

Al disminuir el caudal a $20 \%$, la aW de todas las muestras fue menor a 0,3 , pero la supervivencia de bacterias lácticas se vio muy afectada, seguramente por un aumento de la temperatura salida.

Para el mismo momento en que se realizaron estos experimentos, Atalar y Dirvesoglu (2015) publicaron un trabajo en el cual arriban a unos parámetros similares para el secado spray de kefir, pero utilizando una metodología de análisis de superficie de respuesta para diferentes microorganismos presentes en el producto evaluados por separado.

\subsubsection{Secado directo}

Una vez obtenidos los parámetros óptimos de secado se procedió a caracterizar más detalladamente el producto obtenido a partir del secado en spray de la leche fermentada en las condiciones previamente establecidas. Además del rendimiento porcentual del proceso, se analizaron otros datos relevantes, como la viabilidad de levaduras y el tamaño de partícula 
obtenido. También se evaluó la aW y el contenido de humedad, ya que, como se mencionó, para el almacenamiento a largo plazo del polvo, el contenido de humedad debe estar preferiblemente cercano al $4 \%$ y la aW alrededor de 0,3 para minimizar reacciones de deterioro (Behboudi-Jobbehdar y col., 2013; Dianawati y col., 2013; Shokri y col., 2015; Vesterlund y col., 2012; Ying y col., 2012).

Si bien el producto obtenido (KUHTdir) mostró una aW menor a 0,3 , el contenido de humedad fue del $7 \%$ aproximadamente, lo que resultó ser muy elevado para asegurar una vida útil prolongada. Además, el rendimiento del proceso fue algo bajo, menor al $20 \%$, por lo que debería ser optimizado para representar una ventaja por sobre otros métodos de deshidratación (Tabla 4).

Tabla 4: Características del producto deshidratado obtenido a partir del secado spray de kefir elaborado en leche UHT (KUHTdir). Los valores resumidos en la tabla muestran los resultados de por lo menos tres experimentos independientes.

\begin{tabular}{|c|c|c|}
\hline \multicolumn{3}{|l|}{ Características: KUHTdir } \\
\hline \multirow[t]{2}{*}{ Rendimiento (\%) } & Media & 19,1 \\
\hline & DS & 1,6 \\
\hline \multirow[t]{2}{*}{ aW } & Media & 0,2829 \\
\hline & DS & 0,01 \\
\hline \multirow[t]{2}{*}{ Humedad (\%) } & Media & 7,11 \\
\hline & DS & 0,17 \\
\hline \multirow{2}{*}{$\begin{array}{l}\text { Bacterias Lácticas } \\
\text { (log UFC/g) }\end{array}$} & Media & 5,8 \\
\hline & DS & 0,1 \\
\hline \multirow[t]{2}{*}{ Levaduras (log UFC/g) } & Media & 0 \\
\hline & DS & 0 \\
\hline \multirow{2}{*}{$\begin{array}{c}\text { Tamaño Partícula } \\
(\mu \mathrm{m})\end{array}$} & Media & 11,16 \\
\hline & DS & 3,2 \\
\hline
\end{tabular}


Por otro lado, la viabilidad de las bacterias lácticas en los productos deshidratados obtenidos fue de 5,8 log UFC/g, mientras que los recuentos de levaduras estuvieron por debajo de los límites de detección $(<2 \log \mathrm{UFC} / \mathrm{g})$ (Tabla 4). La presencia de una cantidad adecuada de microorganismos viables en las formulaciones probióticas se considera un criterio esencial para poder garantizar sus beneficios para la salud (Hill y col., 2014). Según las directrices de la Organización de las Naciones Unidas para la Agricultura y la Alimentación (FAO) y la Organización Mundial de la Salud (OMS) (2002), un suplemento alimentario de este tipo debe alcanzar al menos una cantidad de microorganismos viables de 7 log UFC/g. El producto deshidratado obtenido al secar kefir no estuvo tan alejado de estos valores pese a que la pérdida de viabilidad microbiana tras el proceso de deshidratación fue significativa si la comparamos con el producto original.

Muchos autores han explorado diversas estrategias para aumentar la supervivencia de microorganismos durante procesos de deshidratación. Entre ellas, se destaca por su simplicidad y efectividad el aumento en la cantidad de sólidos totales en la muestra. Esta estrategia permite aumentar el rendimiento y la viabilidad de los microorganismos debido al efecto termoprotector de los sólidos de la leche (Corcoran y col., 2004). Según Ananta y col. (2005), se considera que una concentración del $20 \%$ (p/p) de sólidos lácteos no grasos es el contenido óptimo de sólidos para garantizar una alta viabilidad de diferentes cepas de bacterias lácticas.

De esta manera, se propuso elaborar el kefir en leche $20 \% \mathrm{p} / \mathrm{v}$ (que es aproximadamente el doble de contenido de sólidos disueltos que posee la leche UHT). Sin embargo, al fermentar leche descremada reconstituida al $20 \%$ con gránulos de kefir, se obtuvo un producto muy viscoso (360 cPoise) que no pudo ser sometido a la deshidratación por secado spray en el equipo utilizado. 
Como se mencionó en la introducción, se han propuesto otros sustratos para le fermentación con gránulos de kefir, como el permeado de suero (Gamba, 2016). Estudios sobre la cinética de acidificación y de crecimiento (Figura 5) muestran que una solución de permeado de suero $20 \% \mathrm{p} / \mathrm{v}$ incubada durante $24 \mathrm{~h}$ a $20{ }^{\circ} \mathrm{C}$ con $10 \% \mathrm{p} / \mathrm{v}$ de gránulos de kefir alcanza recuentos microbiológicos y acidifica el medio a una velocidad similar a lo que observamos en leche UHT, obteniendo un producto menos viscoso ( 2,8 cpoise) que puede someterse a secado spray. 

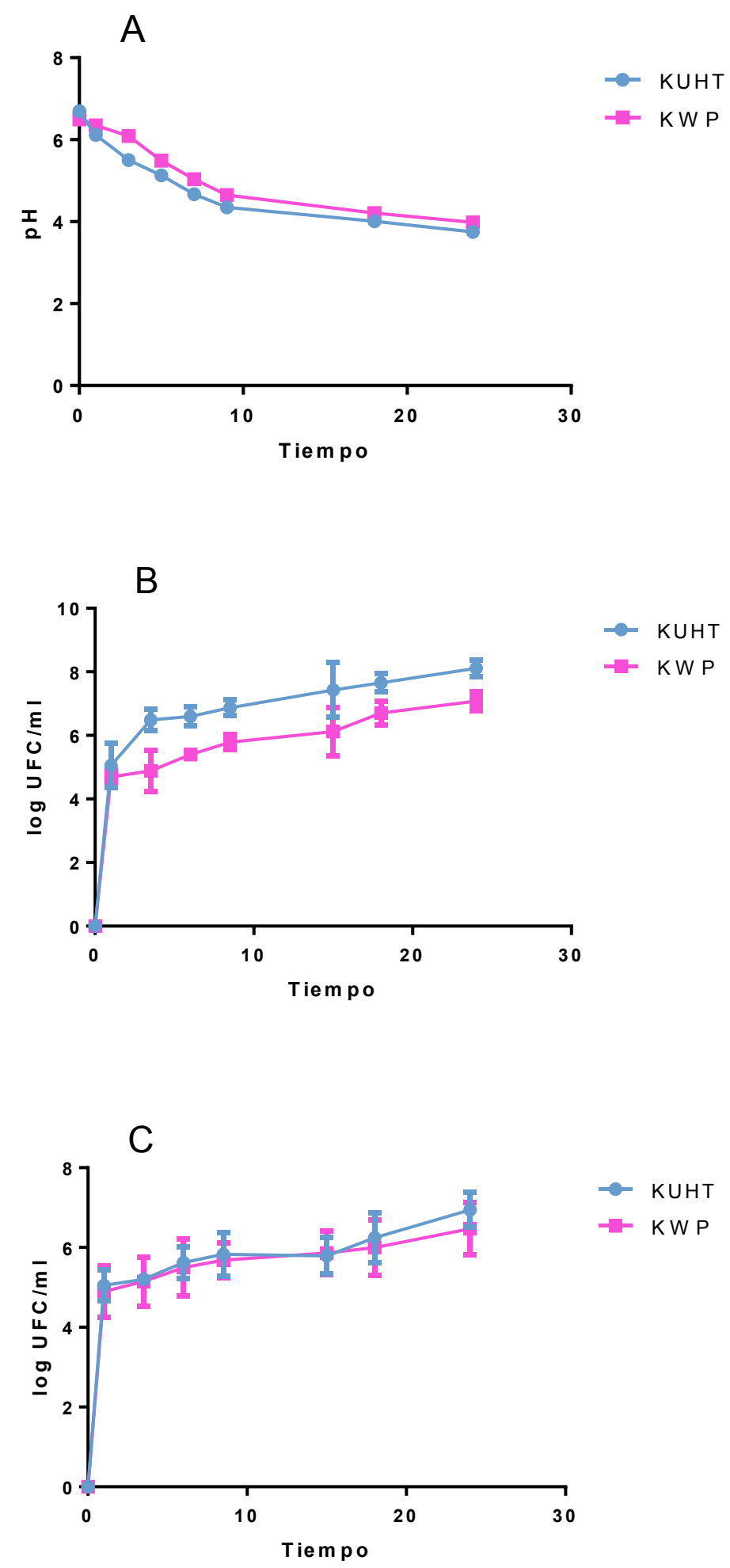

Figura 5: Evaluación del pH en función del tiempo (A) y recuentos microbiológicos de bacterias lácticas (B) y levaduras (C) en función del tiempo de incubación para gránulos de kefir inoculados $(10 \% \mathrm{p} / \mathrm{v})$ en leche UHT (KUHT) o permeado de suero $20 \%$ (KWP). Las barras de error corresponden a la desviación estándar. Los valores graficados muestran los resultados de por lo menos tres experimentos diferentes. 
Antes de deshidratar el permeado de suero fermentado, se realizó un estudio exploratorio para verificar que las mismas condiciones usadas para secar la leche fermentada correspondan con las óptimas para el permeado de suero fermentado, manteniendo el caudal de alimentación del equipo al $30 \%$.

Como se puede ver en la Tabla 5, al igual que para el caso de la leche fermentada, a temperaturas de entrada menores a $130{ }^{\circ} \mathrm{C}$, la muestra no alcanzó a secarse completamente, quedando adherida a las paredes de la cámara de secado. Esto ocurrió debido a que para temperaturas inferiores a $130{ }^{\circ} \mathrm{C}$, la velocidad de alimentación escogida (30 \%) fue superior a la velocidad de deshidratación de las gotas atomizadas en la cámara de secado.

Tabla 5: Valores de actividad de agua y recuentos de baterías lácticas para kefir elaborado en permeado de suero $20 \% \mathrm{p} / \mathrm{v}$ deshidratado con distintas temperaturas de entrada. Los valores resumidos en la tabla muestran los resultados de por lo menos tres experimentos diferentes.

\begin{tabular}{|c|c|c|c|}
$\begin{array}{c}\text { Temperatura } \\
\text { Entrada }\left({ }^{\circ} \mathrm{C}\right)\end{array}$ & $\begin{array}{c}\text { Temperatura } \\
\text { Salida }\left({ }^{\circ} \mathrm{C}\right)\end{array}$ & $\begin{array}{c}\text { Bacterias } \\
\text { Lácticas } \\
\text { (log UFC/g) }\end{array}$ & aW \\
\hline $\mathbf{1 2 0}$ & ND & ND & ND \\
\hline 125 & ND & ND & ND \\
\hline 130 & 61 & 7,0 & 0,31 \\
\hline 135 & 66 & 6,9 & 0,27 \\
\hline 140 & 77 & 6,1 & 0,23 \\
\hline 145 & 82 & 5,9 & 0,23 \\
\hline 150 & 89 & 5,5 & 0,21 \\
\hline
\end{tabular}

ND: No Determinado

Luego, se observó que las condiciones óptimas para el secado coincidían con las obtenidas para la leche fermentada, obteniéndose la máxima viabilidad y una aW menor a 0,3 cuando la temperatura de entrada elegida es de $135{ }^{\circ} \mathrm{C}$ (Tablas 3 y 5). A valores más elevados de temperatura de entrada, la viabilidad disminuyó considerablemente. 
Se propuso entonces el permeado de suero como sustrato de la fermentación, pero en una concentración de solidos del $20 \%$.

Las características del producto obtenido al deshidratar el permeado $20 \%(\mathrm{p} / \mathrm{v})$ fermentado con gránulos de kefir con los parámetros optimizados anteriormente se resumen en la Tabla

6.

Tabla 6: Características del producto deshidratado obtenido a partir del secado spray de kefir elaborado permeado de suero $20 \% \mathrm{p} / \mathrm{v}$ (KWPdir). Los valores resumidos en la tabla muestran los resultados de por lo menos tres experimentos diferentes.

\begin{tabular}{|c|c|c|}
\hline Características KWPdir & \\
\hline Rendimiento (\%) & Media & 34,6 \\
\hline aW & DS & 5,1 \\
\hline & Media & 0,2329 \\
\hline Humedad (\%) & DS & 0,02 \\
\hline Macterias Lácticas & 12,0 \\
\hline (logUFC/g) & Media & 0,42 \\
\hline Levaduras (logUFC/g) & DS & 0,1 \\
\hline Mamaña & 4,8 \\
\hline Tamaño Partícula & DS & 0,8 \\
\hline $\boldsymbol{\mu m})$ & DS & 11,31 \\
\hline
\end{tabular}

La viabilidad de las bacterias lácticas y las levaduras en el producto obtenido fue de $6 \log$ UFC/g y $4 \log$ UFC/g respectivamente y también se observó un aumento significativo (aproximadamente $85 \%$ ) en el rendimiento porcentual del proceso si lo comparamos con KUHTdir. Ambos efectos pueden atribuirse a la mayor cantidad de sólidos presentes en la muestra líquida. 
El número de bacterias lácticas viables detectadas en el producto deshidratado no aumentó significativamente comparado con la muestra KUHTdir, y la reducción del número de bacterias viables respecto al producto original fue significativa en ambos casos (Figura 6 A). Sin embargo si tenemos en cuenta la pérdida de viabilidad porcentual de bacterias lácticas tras la deshidratación (Figura 6 B), podemos observar que duplicar la cantidad de sólidos disueltos disminuyó significativamente $(\mathrm{p}<0,01)$ la pérdida de viabilidad durante el proceso de secado, ya que para KUHTdir se perdió el $30 \%$ de las bacterias lácticas viables, y para KWPdir la disminución fue del $15 \%$ respecto al número de bacterias lácticas presentes en la muestra líquida.

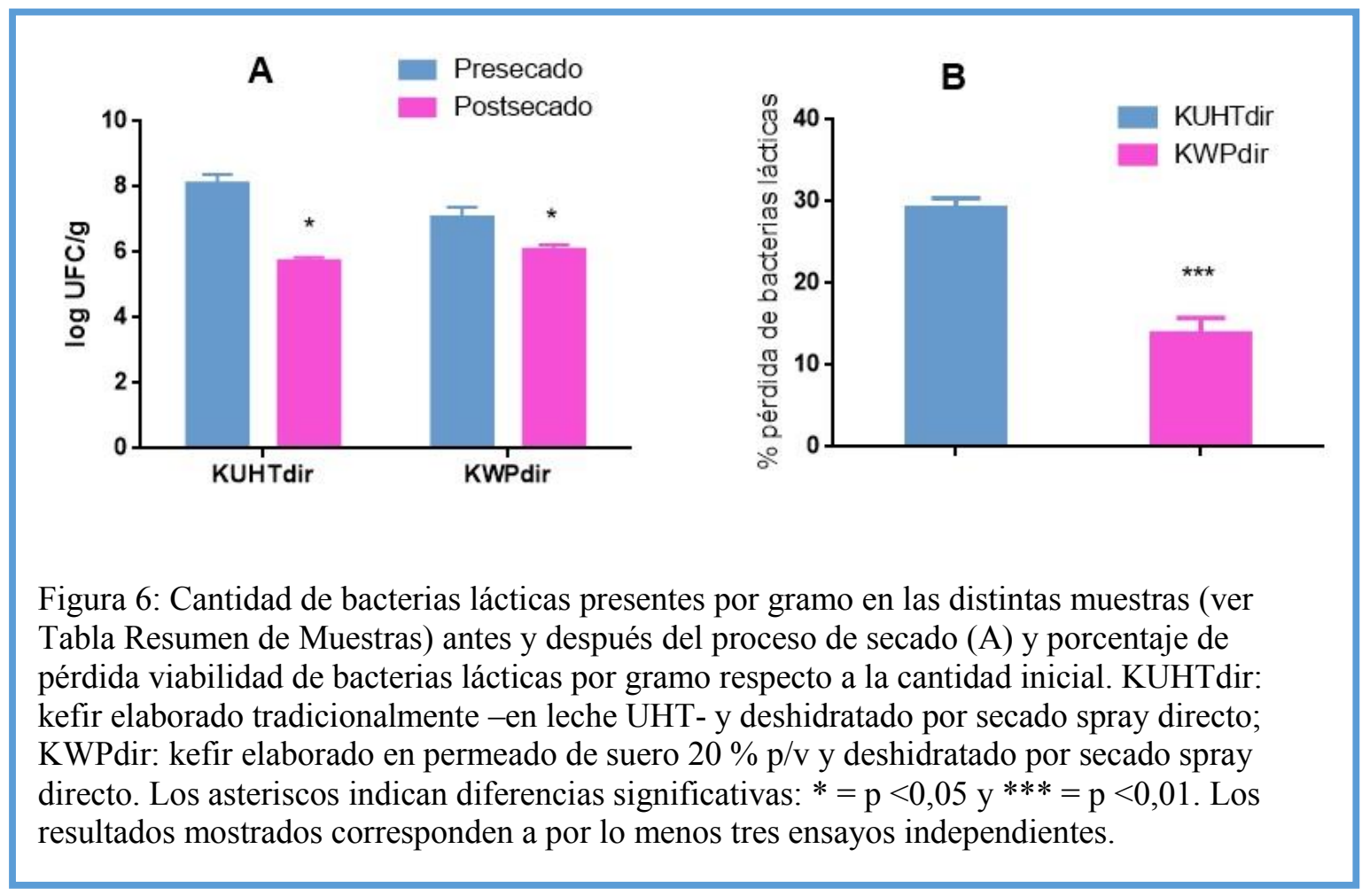

Si bien la aW del producto obtenido fermentando en permeado de suero $20 \% \mathrm{p} / \mathrm{v}$ y deshidratado directamente en las condiciones optimizadas anteriormente es inferior a 0,3 , el contenido de agua es muy superior al recomendable para un producto deshidratado, llegando a casi el $12 \%$. Más aún, a pesar de que el permeado de suero puede ser fermentado por los microorganismos del kefir logrando una acidificación y crecimiento de microorganismos 
similar a la leche, los gránulos usados en este sustrato parecen sufrir cambios con los sucesivos cultivos. Además de tomar un color más pardo (similar al permeado de suero), pierden la turgencia y disminuyen el tamaño (Figura 7). En este sentido, ya se había reportado que la fermentación de permeado de suero en una concentración inferior a la utilizada en nuestros ensayos con gránulos de kefir no generaba un aumento en la biomasa de éstos (Gamba, 2016). Estos cambios en la morfología están relacionados con la composición del medio que si bien es rico en lactosa, es muy pobre en proteínas. Otros autores (Londero y col., 2012; Magalhães y col., 2010) que han utilizado gránulos de kefir para la fermentación de otros derivados del suero lácteo que poseen mayor contenido de proteínas no reportaron cambios morfológicos en los gránulos de kefir tras la fermentación o alteraciones en la composición microbiana del producto obtenido utilizando condiciones de fermentación muy similares a las empleadas en este trabajo. El análisis en profundidad de estos cambios en los gránulos y su incidencia en la composición microbiológica del producto obtenido escapa al alcance de esta tesis pero podría resultar en un producto diferente al kefir tradicional. 

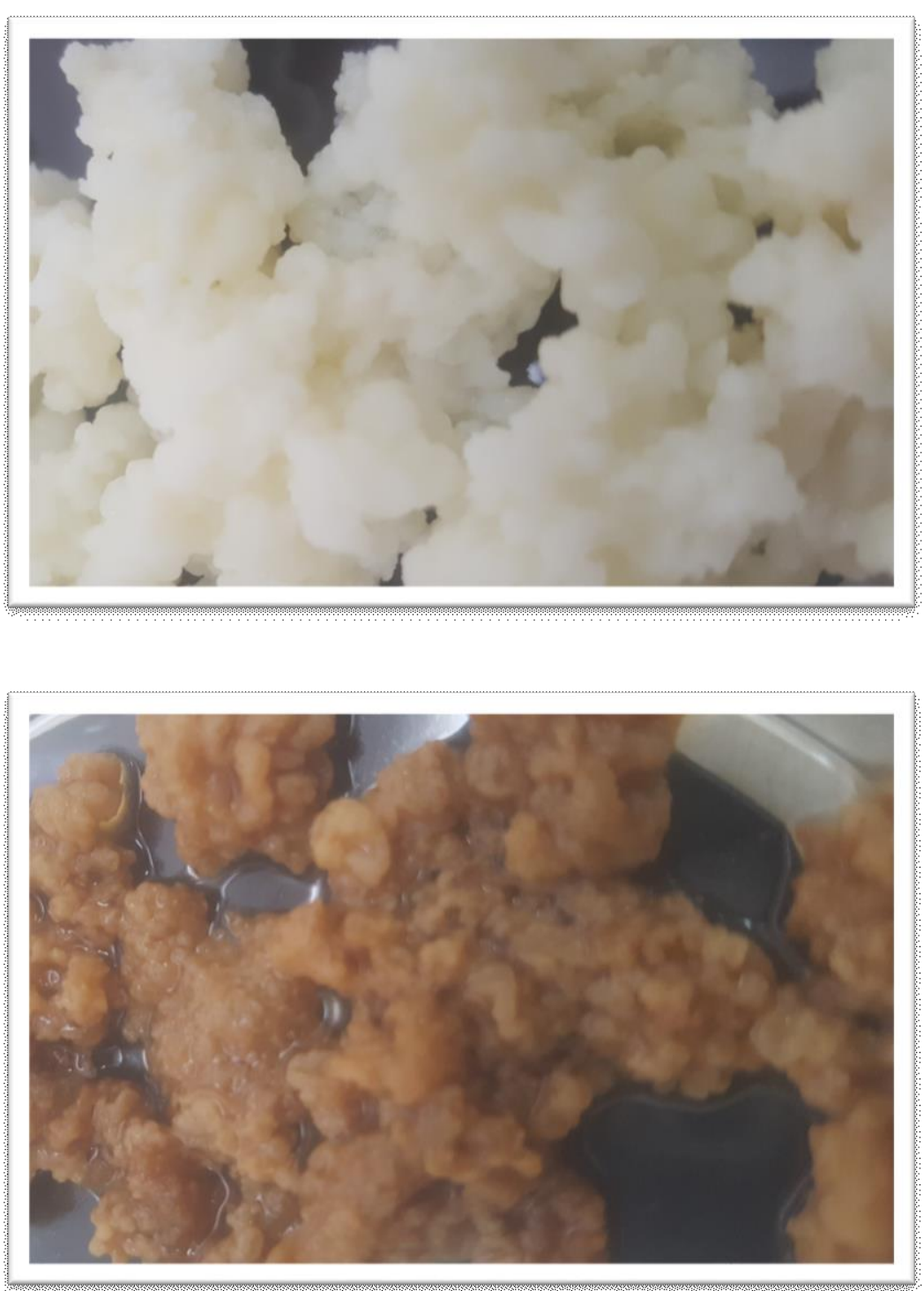

Figura 7: Comparación de los gránulos utilizados para fermentar leche UHT (arriba) y permeado de suero $20 \% \mathrm{p} / \mathrm{v}$ (abajo). Además del cambio de coloración, es notoria la pérdida de turgencia e integridad por parte de los gránulos utilizados en permeado de suero. 


\subsubsection{Secado utilizando carriers}

Debido a que la fermentación en permeado de suero produjo cambios en la morfología de los gránulos, y posiblemente en el producto obtenido, se buscaron otras estrategias para obtener un producto deshidratado a partir de kefir. Como primer medida, se decidió mantener la fermentación en leche UHT y a partir del kefir obtenido explorar estrategias para aumentar la viabilidad en el producto deshidratado.

Como estrategia para aumentar la viabilidad microbiana y optimizar las condiciones para la deshidratación, se estudió el efecto de permeados de suero (que contiene un $85 \%$ p/v de lactosa) y leche descremada, como soluciones carriers para el secado spray, ya sea por si solos o mezclados con maltodextrina o trehalosa, que son dos azucares ampliamente utilizados como agentes termoprotectores (Tabla 2).

El uso de carriers genera condiciones más favorables para el proceso de deshidratación, lo que aumenta la viabilidad de los microorganismos en el producto (Sunny Roberts y Knorr, 2009), y la adición de agentes protectores es una estrategia para proteger bacterias probióticas durante procesos de deshidratación y el subsiguiente almacenamiento. Los agentes protectores pueden ser componentes simples o complejos. Diferentes azúcares (por ejemplo: glucosa, fructosa, lactosa, manosa, sacarosa, sorbitol, adonitol, trehalosa) y otros compuestos como la leche descremada y diversos subproductos de la industria láctea; goma arábiga, glutamato monosódico, maltodextrina, almidón y oligosacáridos han sido utilizado con éxito como medio carrier para la deshidratación por secado spray de microorganismos probióticos (Corcoran y col., 2004; Desmond y col., 2002; Golowczyc y col., 2010; Leslie, et al, 1995; Lian, 2002; Reddy y col., 2009; Santivarangkna y col., 2008; 2007; Silva y col., 2011; Soukoulis y col., 2013; Sunny Roberts \& Knorr, 2009).; Silva y col., 2011; Soukoulis y col., 2013; Ying y col., 2010). 
De esta manera, el kefir elaborado tradicionalmente fue centrifugado y resuspendido en carriers con $20 \%$ de sólidos disueltos previo a someterse al secado spray. Otra estrategia evaluada fue la neutralización de la suspensión carrier previo al secado spray. Han sido publicados resultados contradictorios en referencia a esta modalidad. Algunos autores afirman que la neutralización genera mayores tasas de supervivencia de los microorganismos (Linders y col., 1997), mientras que otros aseguran que se logra una mayor tasa de supervivencia al trabajar con un $\mathrm{pH}$ no controlado (Silva y col., 2005). Esta falta de consenso se debe principalmente a que este efecto depende de la cepa probiótica en cuestión, como reportó Saarela (2005), quien no observó diferencias en la supervivencia de microorganismos al deshidratar B. animalis ssp. lactis neutralizando el pH del carrier.

Los resultados obtenidos con el uso de soluciones carriers se resumen en la Tabla 7. Como se puede observar, la utilización de carriers permite aumentar el rendimiento del proceso con respecto a lo ocurrido para KUHTdir (Tabla 4). Los valores de rendimiento porcentual obtenido se asemejan a los observados para la muestra KWPdir, cuyo contenido de sólidos fue de aproximadamente el $20 \%$. Podemos observar que cuando los carriers fueron neutralizados, el rendimiento obtenido fue mayor que con respecto a las muestras no neutralizadas. Si bien el rendimiento del proceso tiene orígenes multifactoriales (microorganismos, medios de secado, concentración de sólidos, parámetros de secado) y esto dificulta una comparación directa con otros trabajos, Chandralekha y col. (2016) informaron que los rendimientos después del secado spray fueron de $39,5 \%$ y $25,8 \%$ usando leche descremada y maltodextrina respectivamente. Mientras que Arslan y col. (2015) obtuvieron valores de rendimiento superiores al $39 \%$ utilizando soluciones carriers para el secado en spray. 
Tabla 7: Características de los productos deshidratados obtenidos por secado spray utilizando los diferentes carriers. Los valores resumidos en la tabla muestran los resultados de por lo menos tres experimentos independientes.

\begin{tabular}{|c|c|c|c|c|c|c|c|c|c|c|c|c|}
\hline \multirow[t]{2}{*}{ Producto } & \multicolumn{2}{|c|}{ Rendimiento (\%) } & \multicolumn{2}{|c|}{ aW } & \multicolumn{2}{|c|}{ Humedad (\%) } & \multicolumn{2}{|c|}{$\begin{array}{l}\text { Bacterias lácticas } \\
\text { (log UFC/g) }\end{array}$} & \multicolumn{2}{|c|}{$\begin{array}{l}\text { Levaduras } \\
\text { (log UFC/g) }\end{array}$} & \multicolumn{2}{|c|}{$\begin{array}{l}\text { Tamaño partícula } \\
\text { promedio }(\mu \mathrm{M})\end{array}$} \\
\hline & Media & DS & Media & DS & Media & DS & Media & DS & Media & DS & Media & DS \\
\hline SM & 33,0 & 3,1 & 0,2150 & 0,02 & 5,45 & 0,06 & 8,9 & 0,4 & 0 & 0 & 10,27 & 3,01 \\
\hline SMN & 35,9 & 3,1 & 0,1886 & 0,03 & 5,73 & 0,03 & 8,8 & 0,6 & 0 & 0 & 10,79 & 2,97 \\
\hline SMM & 29,9 & 0,6 & 0,2035 & 0,01 & 5,53 & 0,03 & 9,5 & 0,4 & 4,1 & 0,4 & 11,25 & 2,09 \\
\hline SMMN & 37,1 & 1,6 & 0,2179 & 0,02 & 5,21 & 0,37 & 8,8 & 0,3 & 2,4 & 0,7 & 11,21 & 1,97 \\
\hline WP & 23,3 & 2,5 & 0,2100 & 0,02 & 5,29 & 0,15 & 8,1 & 0,1 & 5,2 & 1,1 & 11,27 & 2,34 \\
\hline WPN & 34,5 & 3,9 & 0,3000 & 0,01 & 8,61 & 0,09 & 8,1 & 0,1 & 3,9 & 0,7 & 11,69 & 1,89 \\
\hline WPM & 24,9 & 1,2 & 0,2105 & 0,01 & 5,95 & 0,28 & 9,4 & 0,6 & 4,5 & 0,1 & 11,48 & 2,43 \\
\hline WPMN & 32,8 & 3,6 & 0,2981 & 0,01 & 7,83 & 0,17 & 9,1 & 0,3 & 3,9 & 0,6 & 12,41 & 2,10 \\
\hline MT & 26,3 & 2,4 & 0,2568 & 0,02 & 6,01 & 0,09 & 8,2 & 0,4 & 4,1 & 0,1 & 11,37 & 2,31 \\
\hline WPT & 24,4 & 1,6 & 0,2263 & 0,03 & 5,87 & 0,16 & 8,2 & 0,2 & 3,9 & 0,6 & 12,91 & 1,89 \\
\hline SMT & 28,7 & 1,2 & 0,2488 & 0,01 & 5,76 & 0,06 & 8,2 & 0,1 & 4,0 & 0,2 & 12,15 & 2,27 \\
\hline MTN & 24,7 & 2,1 & 0,2612 & 0,01 & 5,81 & 0,21 & 8,6 & 0,2 & 3,9 & 0,4 & 10,95 & 2,09 \\
\hline WPTN & 24,9 & 0,1 & 0,2574 & 0,02 & 6,55 & 0,19 & 8,4 & 0,3 & 4,0 & 0,3 & 10,99 & 2,21 \\
\hline SMTN & 27,1 & 2,6 & 0,2491 & 0,02 & 5,67 & 0,26 & 8,6 & 0,1 & 4,1 & 0,2 & 11,43 & 2,92 \\
\hline
\end{tabular}


El tamaño de las partículas de los productos obtenido en este tipo de proceso de deshidratación está determinado por el tamaño de la gota de spray formada. En el tipo de tobera utilizado (tobera de dos fluidos) el spray se forma cuando el aire a alta presión entra en contacto con la suspensión líquida, atomizándola. Varios parámetros pueden influir en el tamaño de partícula que se obtiene, como la presión de gas utilizada, la velocidad con la que

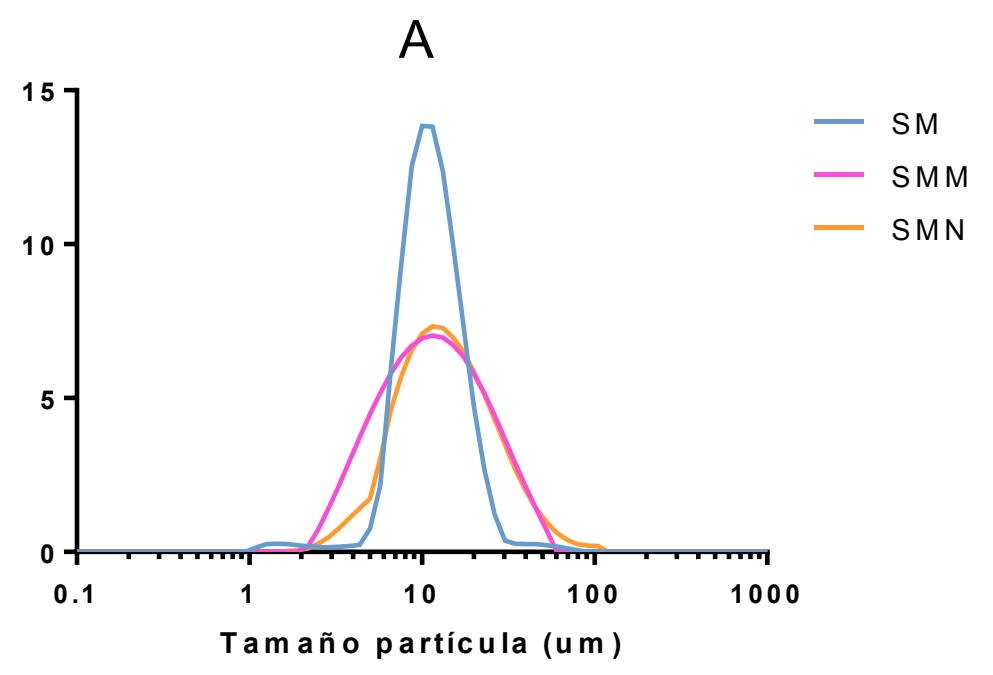

B

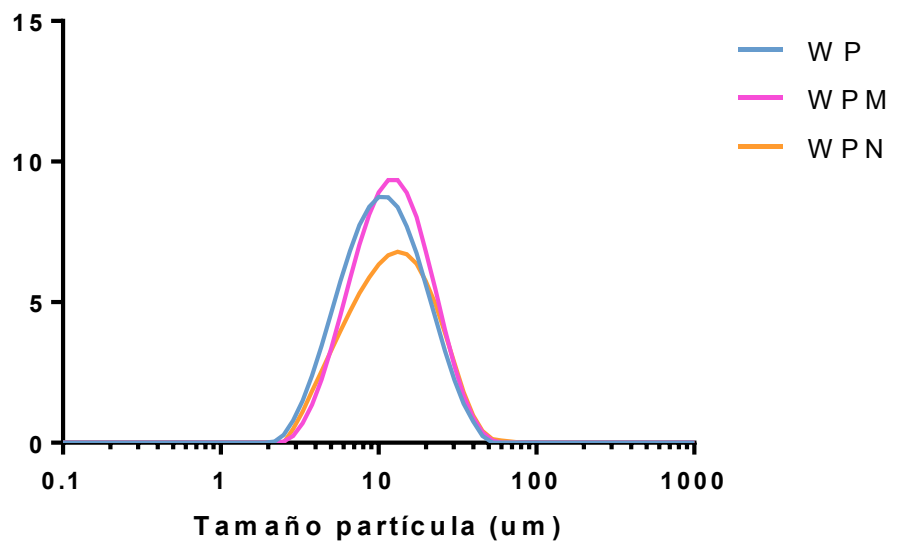

Figura 8: Distribución de tamaño de partícula para los productos deshidratados SM, SMM y SMN (A), y WP, WPM y WPN (B). Ver Tabla Resumen de Muestras 
ingresa la suspensión al sistema, y las propiedades de la suspensión a secar, como la tensión superficial y la viscosidad (Elversson y Millqvist-Fureby,2005; Toro-Sierra y col, 2013).

Para los parámetros de secado seleccionados y la tobera utilizada, que tiene un diámetro de orificio de $0,7 \mathrm{~mm}$, se obtuvieron partículas con un tamaño entre 10 y15 $\mu \mathrm{m}$ de diámetro. En cuanto a la distribución del tamaño de las mismas para los diferentes productos obtenidos, observamos que todas poseen una distribución unimodal y prácticamente simétrica (Figura 8). Sin embargo, se pueden observar diferencias en la curtosis de las curvas obtenidas, es decir en qué tan cerca del valor medio se agrupan los datos obtenidos. Este efecto es notorio para la muestra SM donde los datos se agrupan en un intervalo más pequeño que para las muestras SMM o SMN por ejemplo (Figura 8 A). Ese efecto en la modificación de la curtosis no parece estar relacionado con la presencia de maltodextrina en el carrier, ya que si comparamos las muestras WP y WPM observamos un grado de curtosis similar. Tampoco se observó relación con la neutralización del carrier previo al secado, ya que al comparar las muestras WP y WPM no observamos el mismo fenómeno (Figura 8 B).

La actividad del agua (aW) está relacionada con la disponibilidad de agua libre en la muestra y es un parámetro importante que determina la estabilidad y vida útil de los productos deshidratados (Rahman, 2010). Según Schmidt (2004), los valores de actividad del agua entre 0,001 y 0,25 están relacionados con una alta estabilidad. Sin embargo, como ya se comentó anteriormente, para la elaboración de un producto deshidratado que contenga microorganismos viables es necesario arribar a un valor de aW bajo sin que esto perjudique la viabilidad de dichos microorganismos debido a la necesidad de condiciones de secado que implican altas temperaturas. En el presente trabajo, todas las muestras tuvieron valores de aW entre 0,2 y 0,3 (Tabla 7), lo que proporcionaría una ventaja en el almacenamiento. Según varios trabajos publicados previamente, el contenido óptimo de humedad de los polvos secados por spray es de entre el 4 y el $7 \%$ para lograr estabilidad durante el almacenamiento 
(Ananta y col., 2005; Chávez y Ledeboer, 2007). El contenido de humedad de todas las muestras deshidratadas por secado spray con diferentes carriers osciló entre 5,2 y 5,9\%, excepto las muestras WP y WPM neutralizadas, que tuvieron un contenido de humedad significativamente mayor (entre 7,8 y $8,6 \%$ ).

Todos los carriers evaluados condujeron a un aumento en la supervivencia de las bacterias lácticas en comparación con las muestras obtenidas por secado directo. Se puede suponer que estos resultados están relacionados con el aumento en la cantidad de sólidos totales con efecto termoprotector (Corcoran y col., 2004). Los contenidos de sólidos totales informados de los medios de secado generalmente oscilan entre el 20 y el $30 \%(\mathrm{p} / \mathrm{v})$, y se consideran como óptimos para garantizar una alta supervivencia de diferentes cepas de bacterias lácticas (Huang y col., 2017). En los ensayos realizados para el presente trabajo de tesis, el mayor contenido de sólidos $(20 \%$ p/v) en la muestra probablemente generó una condición más favorable para la deshidratación. Cuando los microorganismos presentes en el kefir fueron suspendidos y deshidratados en carriers que contienen leche descremada, la supervivencia de las bacterias lácticas fue superior a $9 \log \mathrm{UFC} / \mathrm{g}$. Se ha informado que el permeado de suero de leche es un carrier apropiado para el secado spray de lactobacilos (Eckert y col., 2017; Golowczyc y col., 2013; Hugo y col., 2016). Nuestros resultados demostraron que cuando los microorganismos de kefir se suspenden y deshidratan en el permeado de suero (WP) y el permeado de suero más maltodextrina (WPM), la supervivencia de las bacterias lácticas fue superior a $8 \mathrm{log} \mathrm{UFC} / \mathrm{g}$. Sin embargo, cuando los microorganismos de kefir se suspenden y deshidratan en WP y WPM y se neutralizan a pH 7, la supervivencia de las bacterias lácticas fue superior a $9 \log \mathrm{UFC} / \mathrm{g}$. Estos hallazgos están de acuerdo con los resultados reportados por Golowczyc y col. (2013) que demostraron que las condiciones ácidas durante la deshidratación de lactobacilos derivados del kefir constituyen un factor principal que afecta la supervivencia. Podría plantearse la hipótesis de que los compuestos 
ácidos se concentrarían durante el proceso de secado spray, incrementando así los efectos nocivos sobre los microorganismos. Para las muestras obtenidas con carriers que contenían trehalosa, se observa un aumento en la viabilidad al neutralizar el carrier antes del proceso de secado, pero dicho aumento no es significativo.

Dado que las levaduras son, a la vez, de importancia en la funcionalidad probiótica y adecuados indicadores del proceso debido a su baja resistencia térmica, uno de los aspectos abordados fue el estudio de la viabilidad de este grupo de microorganismos del kefir. Los resultados mostraron que cuando los microorganismos del kefir se suspendieron y deshidrataron en leche descremada (SM) y leche descremada más maltodextrina (SMM), los valores de levaduras viables luego del secado estuvieron por debajo del límite de detección por el método de recuento en placa (2 log UFC/g). Por el contrario, cuando los microorganismos de kefir se suspendieron y deshidrataron en leche descremada neutralizada (SMN) o leche descremada más maltodextrina neutralizada (SMMN) la supervivencia de las levaduras estuvo por encima de $3 \log \mathrm{UFC} / \mathrm{g}$. Estos hallazgos demuestran que la neutralización del medio de suspensión es crucial para mantener la viabilidad de las levaduras durante el proceso de secado. Cuando los microorganismos del kefir fueron suspendidos y deshidratados en permeado de suero (WP) y en permeado de suero más maltodextrina (WPM), la supervivencia de las levaduras fue superior a $4 \log \mathrm{UFC} / \mathrm{g}$ y no se encontraron diferencias significativas en comparación con las muestras neutralizadas. Por su parte, la viabilidad de levaduras en las muestras que contenían trehalosa como componente del carrier fue de $4 \log$ UFC/gr aproximadamente, independientemente de si el carrier fuera neutralizado o no previo al proceso de secado.

Varios autores han reportado la baja tolerancia de las levaduras al estrés térmico (Abadias, y col., 2001; Golowczyc y col., 2010), la cual podría estar relacionada la condensación y la reestructuración de la membrana durante el proceso de deshidratación. El efecto protector 
observado en la preservación de la viabilidad de levaduras con aquellos carriers que contenían permeado de suero o trehalosa puede estar relacionado con el efecto termoprotector de los azúcares. En este sentido, Arao y col. (2002) encontraron un efecto protector de varios sacáridos sobre la resistencia de la levadura a altas temperaturas y concluyendo que este efecto está relacionado con el número promedio de grupos $\mathrm{OH}$ ecuatoriales en la molécula de azúcar. Los mecanismos que pueden explicar el efecto protector de estos carbohidratos son las teorías de reemplazo de agua y transición vítrea. La teoría del reemplazo del agua establece que los carbohidratos toman el lugar de las moléculas de agua y establecen puentes de hidrógeno con las cabezas polares de los fosfolípidos de membrana, estabilizando su estructura durante la deshidratación. La teoría de la transición vítrea establece que los microorganismos están incluidos en una matriz vitrificada de azucares que evita que la membrana celular pase de una fase gel a una fase líquida, donde aumenta la movilidad de los lípidos de la membrana perdiéndose su integridad. Cuando el azúcar que se utiliza para reemplazar al agua tiene una temperatura de transición vítrea (Tg) alta, aumenta el valor de temperatura necesario para que la membrana cambie de fase. De esta manera, el reemplazo de agua por azucares con alta $\mathrm{Tg}$, como la trehalosa o la lactosa disminuye los daños en la membrana producido por la alta temperatura del proceso y permite explicar las diferencias observadas en cuanto a la viabilidad de las levaduras.

\subsubsection{Análisis multivariante de componentes principales}

El secado a escala laboratorio utilizando soluciones carriers resultó en un proceso lo suficientemente robusto como para obtener un producto con una cantidad de bacterias lácticas viables elevada y una baja actividad de agua más allá del carrier empleado para la deshidratación. Incluso para otros parámetros evaluados, como el rendimiento o el contenido porcentual de humedad, no se observaron grandes diferencias entre los productos elaborados 
con los distintos carriers. Debido a la gran cantidad de factores evaluados lo cual dificulta tener un panorama general, se procedió a la elaboración de un análisis de componentes principales para poder graficar y examinar los resultados en su conjunto a través de un análisis multivariado. Los gráficos biplot propuestos por Gabriel (Gabriel, 1971) muestran las observaciones y las variables en el mismo gráfico, permitiendo así elaborar interpretaciones sobre las relaciones conjuntas entre observaciones y variables.

Las variables son representadas como vectores desde el origen y las observaciones como puntos en el plano. Los ángulos entre los vectores que representan las variables indican la correlación entre las mismas. Si el ángulo es agudo la correlación es positiva, si es obtuso es negativa. Si el ángulo es recto, no existe correlación entre las variables.

Al realizar el análisis de componentes principales de las muestras secadas con carriers, se obtuvieron las matrices y correlaciones estadísticas entre las variables que se muestran en las Tablas 8 y 9 .

Tabla 8: Matriz de correlación entre las distintas variables evaluadas para los productos deshiddratados utilizando carriers a escala laboratorio.

\begin{tabular}{|c|c|c|c|c|c|c|}
\hline & $\begin{array}{c}\text { Bacterias } \\
\text { lácticas } \\
\text { (log } \\
\text { UFC/g) }\end{array}$ & aW & $\begin{array}{l}\text { Humedad } \\
(\%)\end{array}$ & $\begin{array}{c}\text { Levaduras } \\
\text { (log } \\
\text { UFC/g) }\end{array}$ & $\begin{array}{c}\text { Tamaño } \\
\text { Partícula } \\
\text { (um) }\end{array}$ & $\begin{array}{c}\text { Rendimiento } \\
(\%)\end{array}$ \\
\hline \multicolumn{7}{|l|}{$\begin{array}{l}\text { Bacterias lácticas } \\
\text { (log UFC/g) }\end{array}$} \\
\hline $\mathrm{aW}$ & 0,2259 & & & & & \\
\hline Humedad (\%) & 0,6094 & 0,0004 & & & & \\
\hline $\begin{array}{l}\text { Levaduras (log } \\
\text { UFC/g) }\end{array}$ & 0,4402 & 0,1748 & 0,502 & & & \\
\hline $\begin{array}{c}\text { Tamaño Partícula } \\
(\mu \mathrm{m})\end{array}$ & 0,4198 & 0,1737 & 0,2034 & 0,0555 & & \\
\hline Rendimiento (\%) & 0,3683 & 0,983 & 0,406 & 0,008 & 0,5052 & \\
\hline
\end{tabular}


La matriz de correlación de probabilidades entre las variables (Tabla 8) muestra qué tan relacionadas estadísticamente están las variables entre sí, asignándole un valor numérico entre 0 y 1 . Dos variables tendrán una correlación significativa si el valor de p es menor que el valor de corte asumido. Por ejemplo, se ve que aW y humedad se correlacionan ya que $\mathrm{p}$ $=0.0004$. La Tabla 9 muestra como es la contribución de dichas variables a cada uno de los componentes principales, asignando un valor numérico entre 1 y -1 . Así, la variable aW contribuye fuertemente a $\mathrm{CP} 1$, mientras que casi no contribuye a CP5.

Tabla 9: Correlación de las variables evaluadas con los componentes principales generados por el análisis de los datos para los productos deshidratados utilizando carriers a escala laboratorio.

\begin{tabular}{|c|c|c|c|c|c|c|}
\hline Variables & CP1 & CP2 & CP3 & CP4 & CP5 & CP6 \\
\hline $\begin{array}{c}\text { Bacterias Lácticas } \\
\text { (log UFC/g) }\end{array}$ & $-0,51$ & 0,13 & 0,83 & $-0,17$ & $-0,05$ & 0,06 \\
\hline aW & & & & & & \\
\hline Humedad (\%) & 0,81 & 0,46 & $-0,06$ & $-0,26$ & $1,66 \times 10^{-3}$ & 0,26 \\
\hline Levaduras (log UFC/g) & 0,66 & 0,68 & 0,10 & $-0,16$ & $-0,12$ & $-0,24$ \\
\hline Tamaño partícula ( $\mu$ m) & 0,72 & $-0,50$ & 0,27 & $-0,16$ & 0,29 & $-0,08$ \\
\hline Rendimiento (\%) & $-0,39$ & 0,85 & 0,29 & 0,62 & $-0,08$ & 0,04 \\
\hline
\end{tabular}

Los gráficos biplot obtenidos para los productos deshidratados utilizando carriers se muestran en las Figuras 9, 10 y 11. Estos biplot se realizaron utilizando dos de los componentes principales calculados. El porcentaje de variación que explica cada componente principal se puede observar en los distintos gráficos en el rótulo del eje. Para este análisis, los tres primeros componentes principales permiten explicar el $85 \%$ de la variación total. Los puntos (productos deshidratados) que se hallen más cercanos al centro, son aquellos que muestran menor variación para cada uno de los componentes principales con respecto a la media de todos los productos evaluados, mientras que los más alejados son aquellos que difieren del resto en la característica evaluada representada por el eje sobre el cual se proyectan. 
Al analizar el biplot CP1 vs. CP2 (Figura 9) se observó que las variables rendimiento porcentual y bacterias lácticas viables están relacionadas entre sí, y poseen una correlación negativa con el resto de las variables. También podemos ver, que las variables aW y humedad porcentual presentan, como es de esperar, una fuerte correlación entre sí, como se había destacado al observar la Tabla 8.

Como se observa en la Figura 9, los productos que mostraron mayores valores para las variables de rendimiento y bacterias lácticas viables aparecen para valores negativos de CP1 (mitad izquierda del gráfico), mostrando aquellas con mayor rendimiento en el cuadrante superior izquierdo (como SM y SMN) y las de menor rendimiento en el inferior izquierdo (como SMM y WPM), debido a su proyección relativa al eje que constituye esta variable. WPMN mostró una gran cantidad de bacterias lácticas viables luego del proceso de deshidratación, pero su alto contenido de humedad y su elevada aW, hacen que se ubique en el cuadrante superior derecho, debido a la alta contribución de estas dos variables sobre el CP1.

Por su parte, se puede observar que todas las muestras que contenían trehalosa como componente del carrier presentaron menor variación en cuanto a las características evaluadas, ya que los puntos correspondientes a estos productos aparecieron agrupados en un clúster. Es interesante también evaluar si los puntos graficados en un biplot se mantienen la misma agrupación cuando se grafican otros CP. Si esto ocurre, quiere decir que la distribución de puntos representa a la distribución de puntos en el espacio multidimensional de $\mathrm{n}$ dimensiones (en este caso 6 variables $=6$ dimensiones) original.

Al analizar el biplot de CP2 vs CP3 (Figura 11), por ejemplo, observamos que, pese a que cambiamos la proyección de la variables en el plano, las muestras que contenían trehalosa como componente del carrier continuaron agrupándose juntas, indicando que lo observado 
en el biplot CP1 vs. CP2 (Figura 9) estaba relacionado con el espacio de variables original. Es decir, que el agrupamiento de las observaciones era acorde con los datos originales.

Los productos WPN y WPMN siempre se hallaron a valores positivos de CP1, que mostró una fuerte correlación con mayores valores de humedad y de aW. Más aún, en el biplot CP1 vs CP2 (Figura 9), se puede observar que estos puntos se ubicaron entre la proyección de ambas variables, lo que indicó que éstas son las que más contribuyeron a su variación respecto del resto de las muestras. Esto reflejó el resultado que se observa en la Tabla 7 donde se puede apreciar la aW y la humedad porcentual fue superior para estas muestras. De esta manera, se podría hipotetizar, que la neutralización antes del secado de aquellas muestras que poseen permeado de suero como componente del carrier conlleva un aumento de la aW y la humedad porcentual en el producto final, ya que los productos WP y WPM se ubicaron hacia valores negativos de CP2.

Las muestras SM, SMM, SMN y SMMN siempre presentaron valores negativos para CP1, debido a su menor aW y contenido de humedad que las otras muestras. Además, CP1 se correlacionó también con las levaduras viables en la muestra, los que se tradujo en que las muestras que no presentaron levaduras viables tras la deshidratación (SM y SMN) se hayan proyectado hacia valores más negativos de dicho componente principal.

Debido a que la CP3 está fuertemente relacionada con la viabilidad de bacterias lácticas (Tabla 9), se esperaría que las muestras que presentaron un número similar de bacterias lácticas viables se agrupen juntas para este componente. Efectivamente, las muestras SMM y WPM, con recuentos de alrededor de $9 \log \mathrm{UFC} / \mathrm{g}$, se encuentran cercanas respecto a esta variable. 


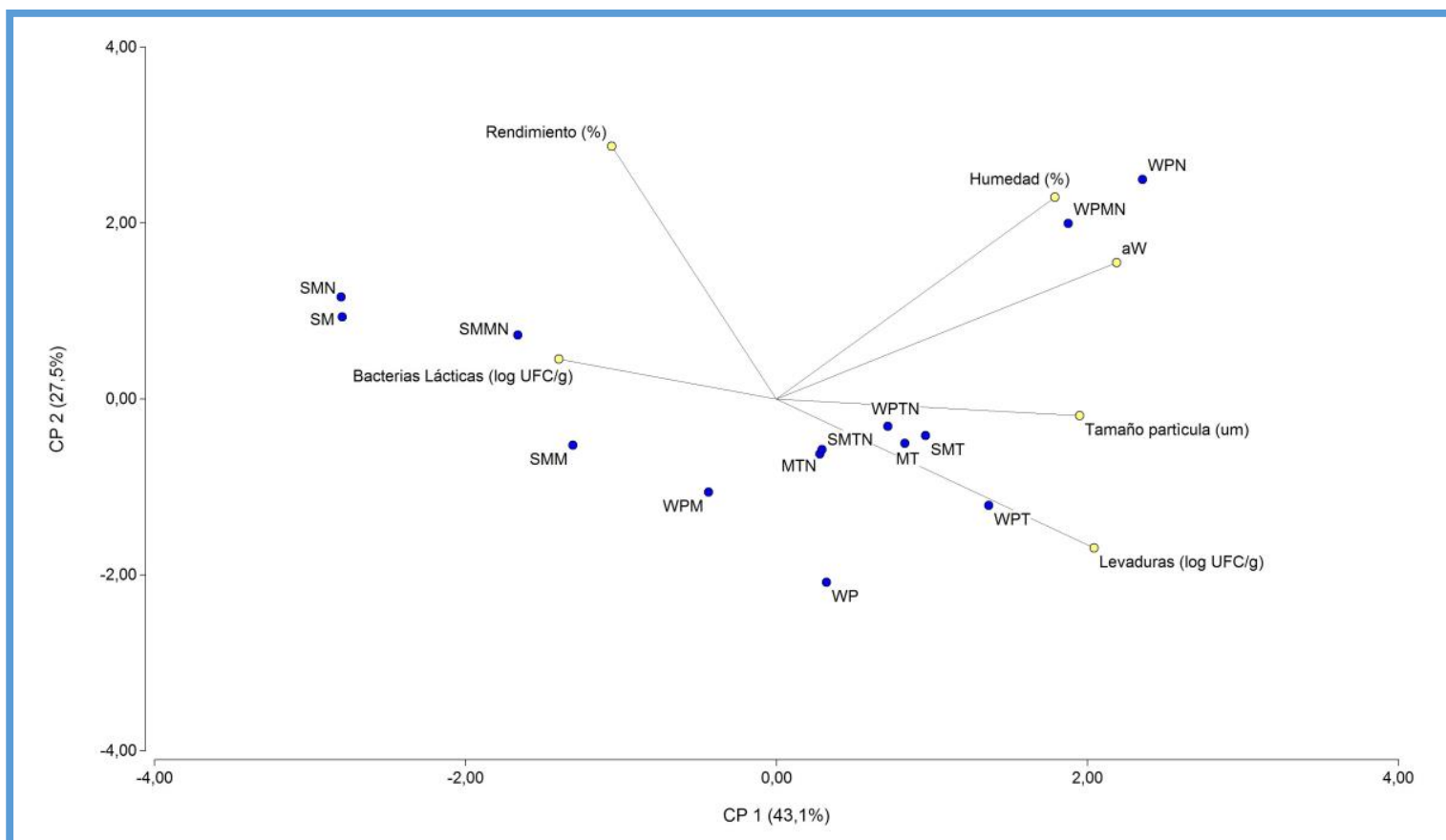

Figura 9: Biplot del análisis de componentes principales: CP1 vs. CP2. En los rótulos de los ejes se observa el porcentaje de la variabilidad explicado por cada componente principal. Ver Tabla Referencia de Muestras.

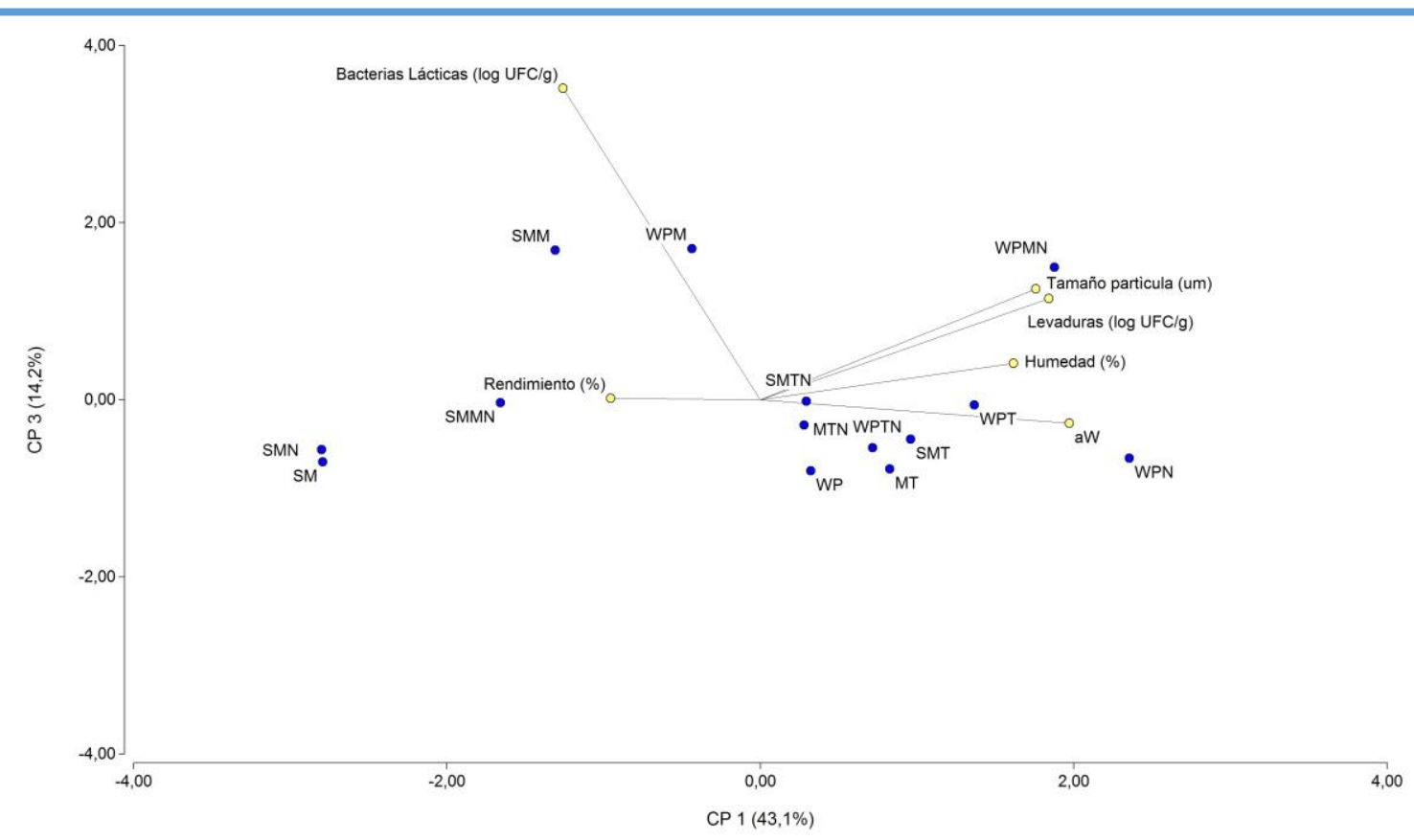

Figura 10: Biplot del análisis de componentes principales: CP1 vs. CP3. En los rótulos de los ejes se observa el porcentaje de la variabilidad explicado por cada componente principal. Ver Tabla Referencia de Muestras. 


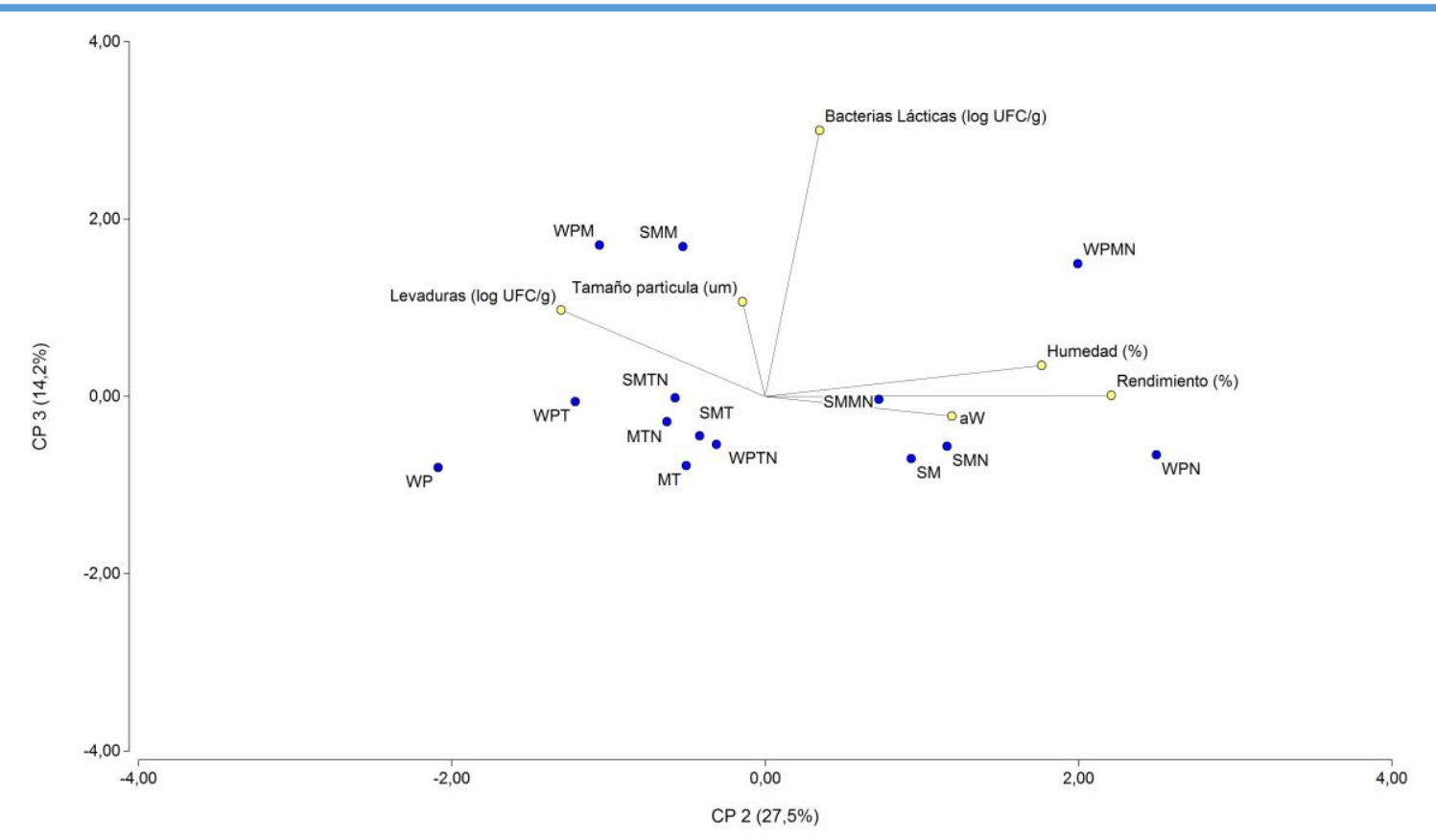

Figura 11: Biplot del análisis de componentes principales: CP2 vs. CP3. En los rótulos de los ejes se observa el porcentaje de la variabilidad explicado por cada componente principal. Ver Tabla Referencia de Muestras.

Por su parte, los productos SM y SMN, se agruparon juntos en los 3 biplot, indicando que existe muy poca variación entre ellos para los parámetros evaluados. Así, para el caso de la leche descremada como carrier, la neutralización no tuvo un efecto sobre los parámetros evaluados. Para el caso de las muestras SMM y SMMN, vemos que si bien ambas presentaron valores negativos para el $\mathrm{CP} 1$, con respecto a los otros $\mathrm{CP}$ el comportamiento observado fue el inverso, ubicándose en cuadrantes diferentes del biplot de CP2 vs CP3. En la Figura 11 se puede observar que SMM fue más importante la influencia del CP3 (relacionado con la viabilidad de lácticas) y para SMMN el CP2, que se relacionó con el rendimiento. Esto indicaría que, para las muestras que contenían leche descremada y maltodextrina como componentes del carrier, la neutralización ejerció un efecto adverso en la supervivencia de bacterias lácticas, pero aumentó el rendimiento porcentual del proceso. 
Después de todo lo expuesto podemos concluir que cuando el carrier empleado es leche descremada, se obtuvieron valores de rendimiento superiores a la media de las muestras (valores negativos de $\mathrm{CP} 1$ y positivos de $\mathrm{CP} 2$ ) y valores de supervivencia de bacterias lácticas ligeramente superiores a la media de las muestras (valores negativos de CP1 y cercanos a cero para CP3) y que, además, su neutralización previo al secado no tuvo influencia en los parámetros evaluados. En cambio, para los productos elaborados con carriers conteniendo leche y maltodextrina, observamos que la neutralización influyó aumentando el rendimiento del proceso en detrimento de la viabilidad bacteriana.

Para la muestras que contenían permeado de suero como componente del carrier ya sea combinado o no con maltodextrina, la neutralización generó un aumento en el rendimiento del proceso, pero también aumentó considerablemente la actividad de agua y el contenido porcentual de humedad en el producto deshidratado respecto de la media (valores positivos para $\mathrm{CP} 1$ y $\mathrm{CP} 2$ ), lo cual podría ser contraproducente para su posterior almacenamiento. Además, se observó también que cuando el carrier consistía solamente en permeado de suero la viabilidad de bacterias lácticas fue baja (valores negativos de CP3), pero que la combinación con maltodextrina generó un aumento de la bacterias lácticas viables presentes en el producto deshidratado, ya que WPM y WPMN mostraron valores positivos para CP3.

Con respecto a las muestras elaboradas con carriers conteniendo trehalosa y como se puede apreciar en los distintos biplot, todas ellas se mantuvieron en un cluster independientemente de que se combine con otro componente o que el carrier sea neutralizado o no previo al proceso de deshidratación. Esto mostró que la presencia de trehalosa en el carrier generó productos con menor variación entre sí, independientemente del componente con el cual se combine. 
Así, se puede decir que los carriers sin neutralizar que contienen maltodextrina en combinación con leche descremada o permeado de suero son aquellos que permiten obtener un producto óptimo en cuanto a las características evaluadas, ya que presentan mayor viabilidad de bacterias lácticas y menor actividad de agua. De estos dos, el mayor rendimiento observado para SMM lleva a considerarlo como el carrier más apropiado.

\subsubsection{Resistencia al pasaje gastrointestinal}

La supervivencia al tránsito gastrointestinal es un requisito crucial para los microorganismos probióticos. El bajo pH y la acción antimicrobiana de la pepsina en el estómago, además de la presencia de sales biliares en el intestino, constituyen barreras que deben enfrentar los microorganismos administrados por vía oral (Nagata y col., 2009). Para todos los productos observamos que la reducción más significativa en la viabilidad microbiana ocurrió luego de la incubación en la solución gástrica $(\mathrm{p}<0,01)$ (Figura 12), probablemente por el bajo $\mathrm{pH}$ en dicha solución $(\mathrm{pH}=2,5)$.

Al final de la simulación gastrointestinal, se observó que, para las muestras SM y SMM, la disminución de las bacterias lácticas viables no excedió el 17\% (1,5 log UFC/ml). Sin embargo, para las muestras SMN y SMMN hubo una disminución mayor en la viabilidad (1,5 y 1,6 log UFC/ml respectivamente), indicando que la neutralización del carrier previo al secado spray tiene luego un efecto negativo en la resistencia al pasaje gastrointestinal por parte del producto deshidratado elaborado. 
Para WP y WPM, las bacterias lácticas disminuyeron 1,5 y 2,1 log UFC/ml respectivamente al final de la simulación, lo que equivale a una pérdida del 19,5 y del 26,6 \% del número inicial de bacterias lácticas respectivamente. Para estas muestras, la neutralización del carrier no tuvo un efecto significativo, ya que para WPN y WPMN observamos una disminución similar, de 1,6 y 2,06 log UFC/ml respectivamente. Por su parte, al estudiar el efecto de la trehalosa como componente de la solución carrier se observó nuevamente que la neutralización tuvo un efecto negativo sobre la resistencia al pasaje por el tracto gastrointestinal. Sin embargo, la disminución en la viabilidad fue menor cuando la trehalosa se combinó con leche descremada en el carrier. Estos resultados indicaron que la presencia de leche descremada en el carrier mejora la supervivencia de bacterias lácticas a las condiciones gastrointestinales simuladas.

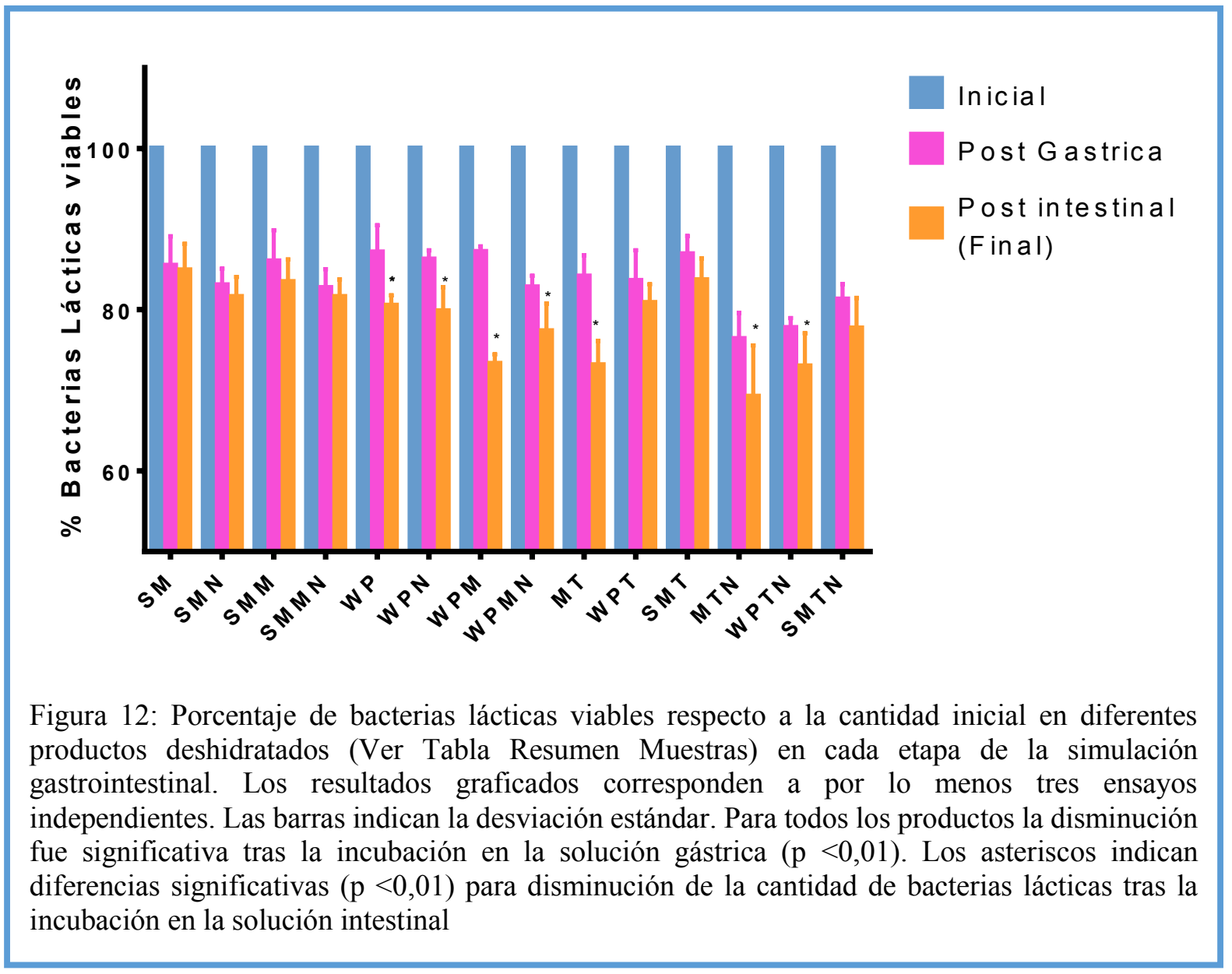


La resistencia a las condiciones gástricas e intestinales simuladas es una propiedad que depende tanto del microrganismo probiótico como de las condiciones en las que se realiza la simulación (Dianawati y col., 2016; Fernandez de Palencia y col, 2008), lo cual dificulta las comparaciones entre diferentes investigaciones. Además, para este caso en que el probiótico forma parte de un producto deshidratado, también dependerá de la composición del producto y las condiciones en las que se deshidrató. El secado spray implica un elevado estrés por calor para los microorganismos, que se traduce en general en daño de la pared y de la membrana celular (Desmond y col., 2001). Estos daños hacen que los microrganismos sean menos resistentes a un estrés adicional, como el que representa el bajo $\mathrm{pH}$ de la simulación gástrica.

La presencia de azúcares (Corcoran y col., 2005), o de leche descremada (Heidebach y col., 2009) permite aumentar la supervivencia de bacterias probióticas durante el pasaje gastrointestinal. Incluso, Ilango y col. (2016) informaron altas tasas de supervivencia (98-99 \%) para bacterias lácticas deshidratadas por secado spray luego de la simulación de condiciones gástricas e intestinales utilizando leche descremada como carrier. La leche descremada se usa comúnmente como un medio carrier para el secado de bacterias porque previene el daño celular al estabilizar las biomoléculas constituyentes de la membrana celular. Además, crea una estructura porosa en el producto deshidratado y contiene proteínas que proporcionan una cubierta protectora para la célula (Abadias y col., 2001; Paez y col., 2013; Soukoulis y col., 2014). Se puede decir que las bacterias secadas por spray utilizando leche descremada (combinada con otro componente o no) como carrier han sufrido menos daños durante el proceso de secado, por lo que son más resistentes al paso a través de las condiciones gastrointestinales simuladas. Además, se cree que las proteínas de la leche poseen capacidad de amortiguar cambios de $\mathrm{pH}$, evitando que el pH gástrico más bajo afecte a las bacterias probióticas deshidratadas en presencia de proteínas (Heidebach y col., 2009). 
Con respecto a las levaduras (Figura 13), para aquellas muestras que contenían WP como componente en su suspensión carrier se pudieron detectar levaduras tras la simulación gástrica, pero en muy baja cantidad. La pérdida de viabilidad observada para estas muestras tras la simulación gástrica fue en todos los casos superior al $70 \%$, lo que corresponde a una pérdida entre 2 y $4 \log$ UFC aproximadamente, dependiendo del producto deshidratado en cuestión.

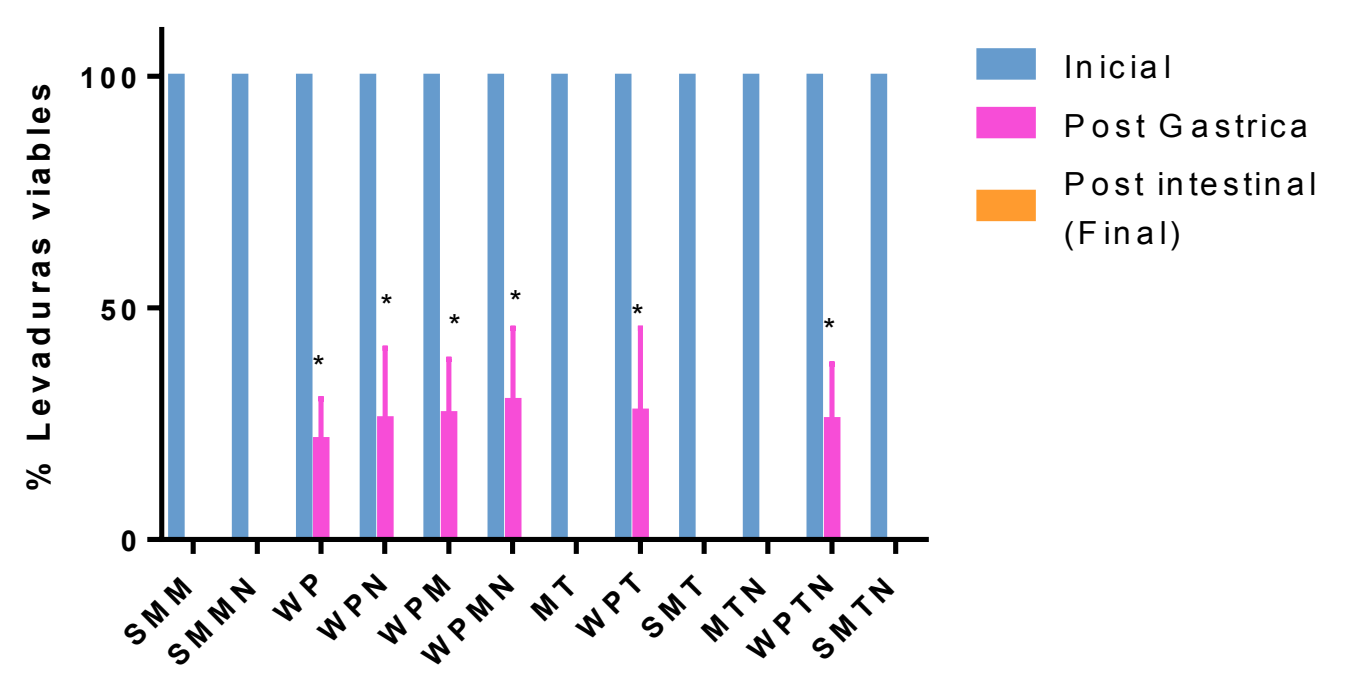

Figura 13: Porcentaje de levaduras viables respecto a la cantidad inicial para cada uno de los productos deshidratados (Ver Tabla Resumen Muestras) en cada etapa de la simulación. SM y SMN no fueron evaluadas debido a que no presentaron levaduras viables tras el proceso de secado spray. Los asteriscos indican diferencias significativas $(p<0.01)$ para disminución de la cantidad de bacterias lácticas tras la incubación en la solución intestinal. No se detectaron levaduras tras la simulación intestinal. Los resultados graficados corresponden a por lo menos tres ensayos independientes.

A pesar de que no existen informes acerca del comportamiento de levaduras deshidratadas por secado spray durante la simulación del pasaje gastrointestinal, otros autores reportaron pérdidas de viabilidad similares para levaduras microencapsuladas (Ghorbani-Choboghlo y col., 2015; Zivkovic y col., 2015; Niamah y col., 2018). Se podría hipotetizar que el permeado de suero ( $85 \%$ lactosa) posee un efecto protector para las levaduras frente al estrés 
ácido que significa el pasaje gástrico. Sin embargo, tras la simulación intestinal, ya no pueden ser detectadas las levaduras en ninguno de los productos analizados. Es sabido que el estrés sufrido por las levaduras durante la deshidratación afecta su posterior viabilidad. Esto, sumado al estrés por $\mathrm{pH}$ ácido de la simulación estomacal y el estrés por simulación intestinal, explicaría el hecho de no hallar levaduras al finalizar simulación

\subsubsection{Capacidad acidificante e inhibición del crecimiento de Salmonella}

La capacidad acidificante se define como la capacidad de un producto probiotico deshidratado para acidificar un determinado medio. La capacidad acidificante incluye la viabilidad celular y el estado fisiológico y es un criterio para evaluar la calidad del producto obtenido. Las pruebas de actividad para las bacterias lácticas se basan normalmente en mediciones de la disminución del pH durante la incubación de leche inoculada en relación al tiempo de incubación. Al inocular $10 \mathrm{ml}$ de leche UHT con $1 \mathrm{gr}$ de los diferentes productos deshidratados, todos ellos mostraron a capacidad acidificante (Figura 14), observándose una disminución del valor del pH luego de 4 horas de incubación y que continúa disminuyendo durante el transcurso de la misma. Si bien la velocidad de acidificación fue menor que la observada durante la incubación con los gránulos de kefir tanto en leche como en permeado de suero (Figura 5), la disminución del $\mathrm{pH}$ indica que los microrganismos presentes en los productos deshidratados poseen su metabolismo activo, lo cual es una condición importante para el carácter probiótico del producto. 
De esta manera, se pudo comprobar que las bacterias lácticas viables presentes en los distintos productos deshidratados conservaron su actividad acidificante. Con objeto de profundizar en la actividad probiótica de dichos productos, se realizaron ensayos de difusión en agar contra un patógeno gastrointestinal como la Salmonella enterica. Para los ensayos realizados en el presente trabajo se utilizaron 3 diferentes cepas de Salmonella enterica serovar Enteritidis: SE105, SE106 y SE115 del cepario del CIDCA.

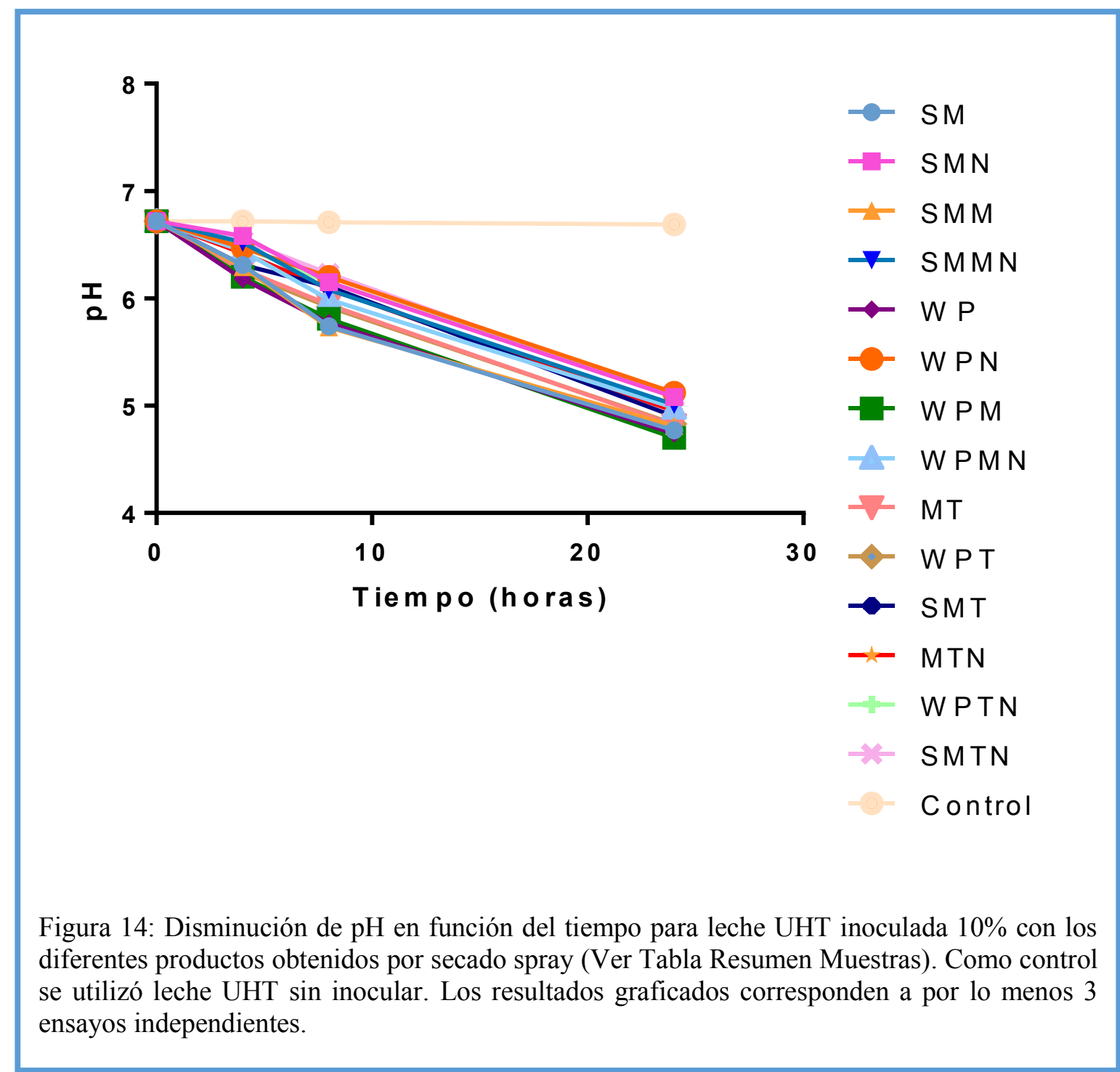

La capacidad antagónica por parte de los microorganismos del kefir contra Salmonella ha sido reportada extensamente por varios autores (Chifiriuc y col., 2011; Golowczyc ycol., 2007; Kim, 2016), incluso en kefir elaborado en permeado de suero (Londero y col., 2014). Esta actividad inhibitoria puede deberse a varios factores, entre los que se destacan la 
producción de ácidos orgánicos y otros metabolitos pero también puede postularse la producción de otros factores tales como las bacteriocinas.

Como se puede observar en las Figuras 15 y 16, todos los productos deshidratados mostraron la capacidad de inhibir el crecimiento del patógeno. Esta capacidad se relaciona directamente con la presencia de microorganismos en los productos deshidratados, ya que al evaluar los carriers secados en las mismas condiciones pero sin los microorganismos del kefir no se observó inhibición de las cepas de Salmonella. Los halos de inhibición para todos los productos deshidratados con microorganismos de kefir fueron mayores a los $5 \mathrm{~mm}$, lo que indica que la presencia de microorganismos en el producto deshidratado es fundamental para que el éste mantenga su capacidad inhibitoria frente a Salmonella. Los valores de diámetro medio de inhibición obtenidos para todos los productos deshidratados son similares a los obtenidos para el kefir fresco recién elaborado, demostrando que los productos deshidratados derivados del kefir conservan la capacidad de inhibición de Salmonella.

Como se mencionó en la introducción, existen varios reportes acerca de la actividad antagónica de kefir y de cepas provenientes de éste frente a Salmonella (Chang y col., 2018; Golowczyc y col., 2007, 2008; Londero y col., 2015). Los estudios con diferentes cepas aisladas han postulado diversos mecanismos que podrían contribuir a la inhibición de este patógeno. Así, este efecto inhibitorio podría atribuirse a los diferentes metabolitos secretados por las bacterias lácticas, como bacteriocinas y/o ácidos orgánicos. Habiendo comprobado la conservación de la capacidad acidificante de los productos desarrollados, que fue similar para todos ellos, y conociendo la alta capacidad inhibitoria de los ácidos orgánicos producidos por el kefir, podemos inferir en que éstos serían los responsables de la actividad antagónica frente a Salmonella, ya que los halos de inhibición generados por todos los productos fueron similares. 
A

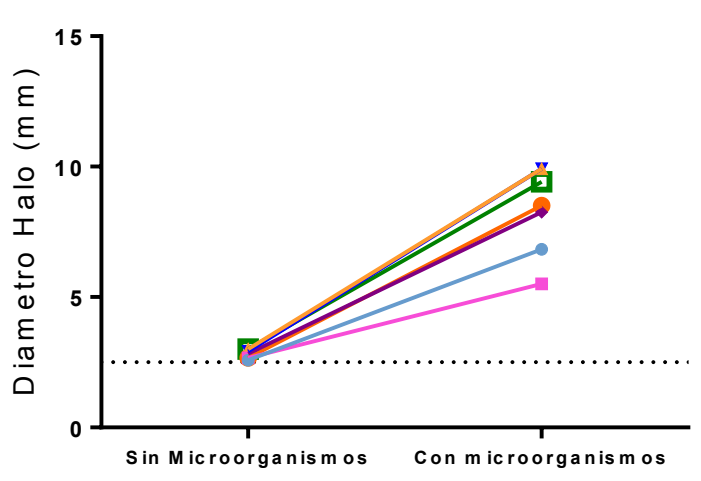

B

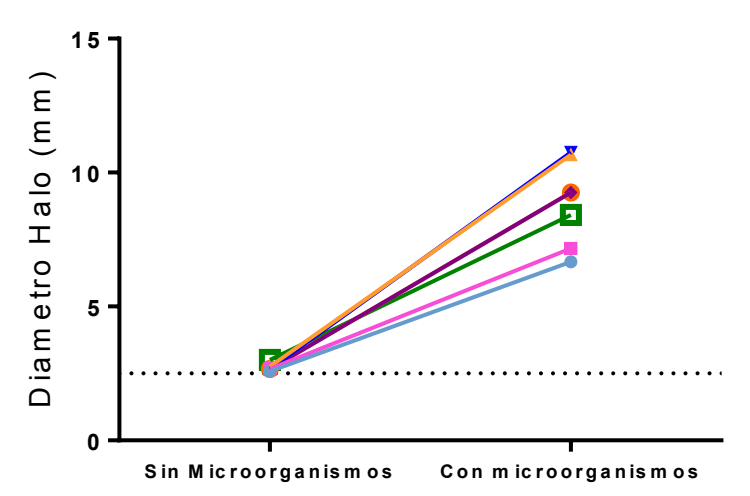

C

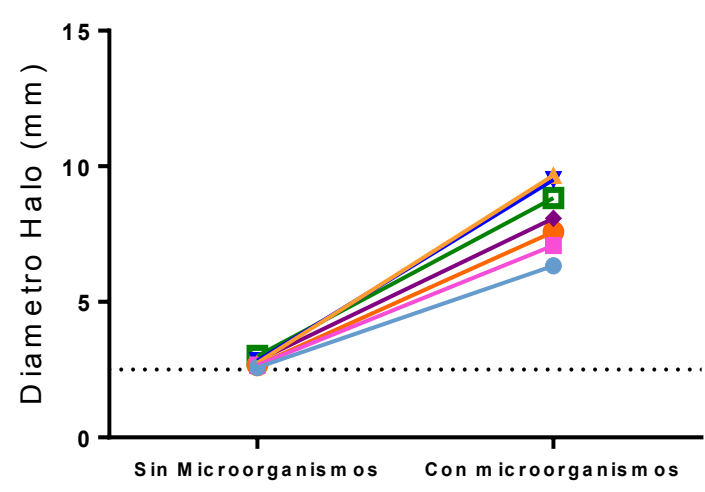

\# Kefir Fresco

- SMTN

$\leadsto$ SMT

$\rightarrow$ SMMN

$\simeq S M M$

- $S M N$

$\rightarrow$ SM

Figura 15: Diámetro (mm) de los halos de inhibición de los diferentes productos obtenidos mediante secado con carriers conteniendo leche descremada como componente (Ver Tabla Resumen Muestras) versus tres cepas diferentes de Salmonella enterica serovar Enteritidis: SE105(A), SE106(B) y SE115(C); comparados con el kefir elaborado tradicionalmente (kefir fresco). En todos los casos, las muestras sin microorganismos hacen referencia al carrier sin los microorganismos del kefir, o a leche UHT para el caso del kefir fresco. La línea punteada corresponde al diámetro de la fosa donde se colocó el producto deshidratado (2,5mm). Los valores graficados corresponden a por lo menos tres ensayos independientes. 
A

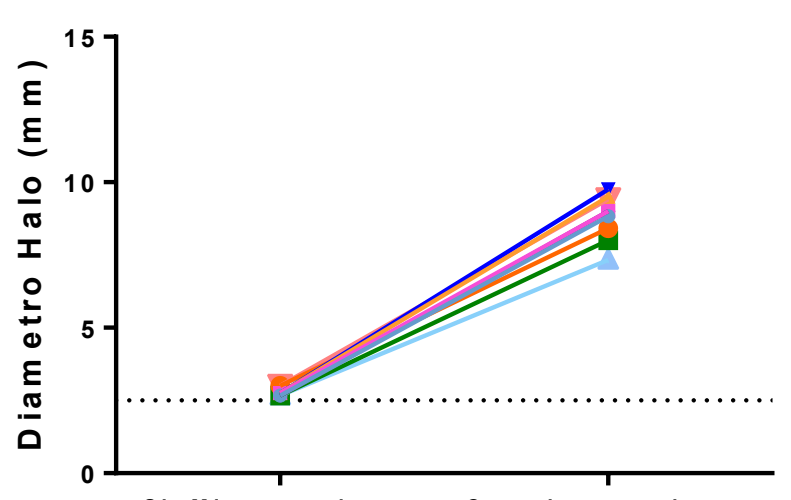

Sin Microorganismos Con microorganismos
B

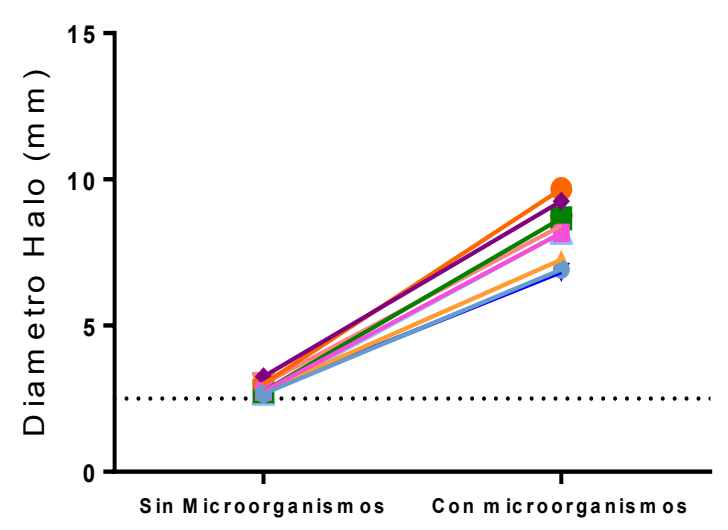

C

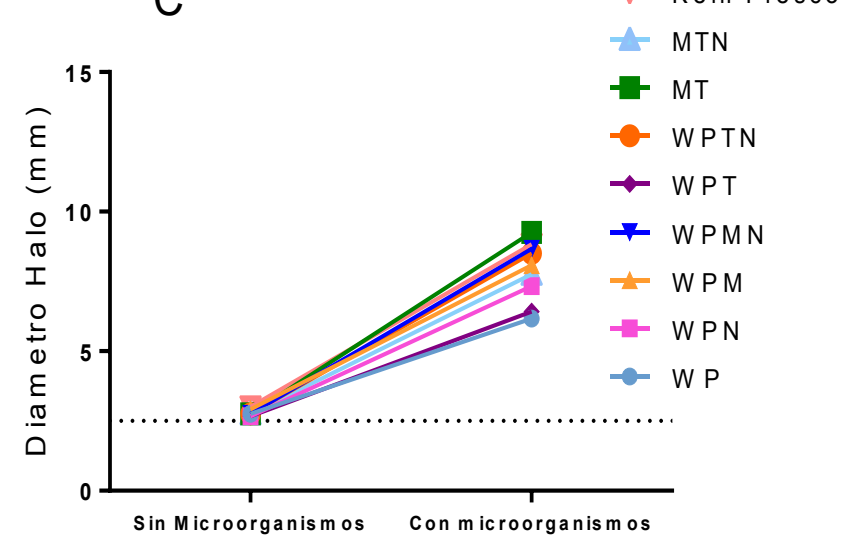

Figura 16: Diámetro $(\mathrm{mm})$ de los halos de inhibición de los diferentes productos obtenidos mediante secado con carriers conteniendo permeado de suero o trehalosa como componente (Ver Tabla Resumen Muestras) versus tres cepas diferentes de Salmonella enterica serovar Enteritidis: SE105(A), SE106(B) y SE115(C); comparados con el kefir elaborado tradicionalmente (kefir fresco). En todos los casos, las muestras sin microorganismos hacen referencia al carrier sin los microorganismos del kefir, o a leche UHT para el caso del kefir fresco. La línea punteada corresponde al diámetro del well donde se colocó el producto deshidratado (2,5 mm). Los valores graficados corresponden a por lo menos tres ensayos independientes. 


\subsubsection{Identificación de especies resistentes al secado spray}

Según indica la FAO, dado que las propiedades probióticas dependen del microorganismo, es necesario identificar las especies encontradas en los productos probióticos desarrollados, siendo la tipificación génica el método más adecuado (FAO/WHO 2006).

Con el objetivo de realizar un estudio con métodos independientes del cultivo, se intentó primeramente desarrollar un método de extracción de ADN total a partir de la muestra deshidratada. Sin embargo, los resultados obtenidos no fueron satisfactorios ya que el material genético se perdía en alguno de los pasos o no tenía la calidad adecuada para los ensayos planeados. Por lo tanto, se decidió aislar las colonias obtenidas de los recuentos microbiológicos de los productos deshidratados, es decir, aquellos microorganismos viables luego del proceso de secado. Las colonias aisladas fueron luego clasificadas de acuerdo a la muestra de procedencia, morfología de colonia y a sus características microscópicas, como forma de la bacteria y coloración Gram. Todas las colonias aisladas tuvieron un diámetro inferior a $5 \mathrm{~mm}$ y fueron opacas. Las tinciones de Gram mostraron que todos los

Tabla 10: Tipos morfológicos de las colonias aisladas durante los recuentos microbiológicos de los distintos productos deshidratados que fueron seleccionadas para la identificación por secuenciación de ADN 16S. Las muestras de origen corresponden a los distintos productos deshidratados resumidos en la Tabla Resumen de Muestras.

\begin{tabular}{|c|c|c|c|c|}
\hline \multirow[t]{2}{*}{ Muestra } & \multirow{2}{*}{$\begin{array}{l}\text { Características } \\
\text { Microscópicas }\end{array}$} & \multicolumn{2}{|c|}{ Características Macroscópicas } & \multirow{2}{*}{$\begin{array}{l}\text { Muestra } \\
\text { Origen }\end{array}$} \\
\hline & & Colonia color & Colonia Forma & \\
\hline 1 & Bacilo & Blanco/beige & $\begin{array}{l}\text { Ligeramente } \\
\text { elevada/cremosa }\end{array}$ & $\mathrm{SM}$ \\
\hline 2 & Bacilo & Beige & $\begin{array}{l}\text { Ligeramente } \\
\text { elevada/cremosa }\end{array}$ & WP \\
\hline 3 & Coco & Blanco & Lisa/ borde uniforme & SMM \\
\hline 4 & Bacilo & Blanco/beige & Lisa/Cremosa & SMM \\
\hline 5 & Bacilo & Blanco & $\begin{array}{l}\text { Ligeramente } \\
\text { elevada/cremosa }\end{array}$ & WPM \\
\hline 6 & Coco & Blanco/beige & Lisa/ borde uniforme & WPM \\
\hline 7 & Coco & Blanco/beige & Lisa/ borde uniforme & WP \\
\hline 8 & Bacilo & Blanco/beige & Lisa/Cremosa & SM \\
\hline
\end{tabular}


microorganismos eran Gram (+). Luego se seleccionaron diferentes tipos morfológicos para la extracción de ADN según se detalla en la Tabla 10.

Se extrajo ADN total de las muestras seleccionadas y fue enviado a secuenciar a MRDNA Labs. (Texas, EEUU). Las secuencias obtenidas fueron comparadas utilizando BLAST (basic local alignment search tool), un algoritmo que permite comparar secuencias de nucleótidos con una base de datos, en este caso se utilizó la base de datos de NCBI (National Center for Biotechnology Information).

Tabla 11: Resultados de la identificación por secuenciación del gen de ARN16S para los distintos tipos morfológicos aislados de los recuentos microbiológicos de los diferentes productos deshidratados. ID indica la especie de la base de datos con la que se reportó mayor semejanza entre el amplicón de la colonia aislada y la base de datos. El porcentaje de semejanza se muestra en la columna \% ID.

\begin{tabular}{|c|c|c|c|}
\hline $\begin{array}{c}\text { Colonia } \\
\text { Nro. }\end{array}$ & ID & $\%$ ID & $\begin{array}{c}\text { Tamaño } \\
\text { (bp) }\end{array}$ \\
\hline 1 & Lactobacillus plantarum & 100,00 & 633 \\
\hline 2 & Lactobacillus plantarum & 99,87 & 771 \\
\hline \multirow[t]{3}{*}{3} & Enterococcus faecalis & 99,87 & \multirow[t]{3}{*}{785} \\
\hline & Enterococcus durans & 99,87 & \\
\hline & Enterococcus lactis & 99,87 & \\
\hline 4 & Lactobacillus plantarum & 94,70 & 755 \\
\hline 5 & Lactobacillus plantarum & 96,02 & 778 \\
\hline \multirow[t]{3}{*}{6} & Enterococcus faecalis & \multirow[t]{3}{*}{99,79} & \multirow[t]{3}{*}{483} \\
\hline & Enterococcus durans & & \\
\hline & Enterococcus lactis & & \\
\hline \multirow[t]{3}{*}{7} & Enterococcus faecalis & \multirow[t]{3}{*}{98,23} & \multirow[t]{3}{*}{735} \\
\hline & Enterococcus durans & & \\
\hline & Enterococcus lactis & & \\
\hline \multirow[t]{3}{*}{8} & Lactobacillus plantarum & \multirow[t]{3}{*}{100,00} & \multirow[t]{3}{*}{677} \\
\hline & Lactobacillus spp. & & \\
\hline & Enterococcus durans & & \\
\hline
\end{tabular}

Como se observa en la Tabla 11, las colonias aisladas de los recuentos corresponden a dos géneros bacterianos: Lactobacillus y Enterococcus. En particular, aquellas colonias que correspondían al género Lactobacillus, arrojaron una gran homología con Lactobacillus 
plantarum cuando las secuencias obtenidas fueron comparadas con la base de datos de NCBI utilizando el algoritmo BLAST. Este resultado concuerda con otros reportes que aseguran que algunas cepas de lactobacilos tienen una mayor resistencia al calor (Gardiner y col. 2000; Reddy y col. 2009). Ambos autores, además, destacan que este fenómeno de resistencia térmica es estrictamente específico de las lactobacilos pertenecientes a las especies $L$. plantarum, L. salivarius y L. paracasei, caracterizadas por tener mayor termotolerancia durante el secado spray.

\subsubsection{Almacenamiento de los productos obtenidos a escala laboratorio}

Una vez obtenido el producto deshidratado, éste fue almacenado para evaluar su vida útil. Cuando este concepto es aplicado a un alimento, hace referencia al periodo de tiempo que transcurre desde el envasado hasta que dicho alimento pierde sus propiedades físicoquímicas y/u organolépticas mínimas aceptables para el producto en cuestión. Para el caso de los productos elaborados en el presente trabajo de tesis, que contienen microorganismos probióticos, y como primera aproximación para la determinación de la vida útil, se evaluaron dos parámetros principales: la viabilidad microbiana y la actividad de agua (aW).

\subsubsection{Muestras obtenidas por secado directo}

Las muestras obtenidas por secado directo KUHTdir y KWPdir mostraron un comportamiento similar en cuanto a la supervivencia de bacterias lácticas (Figura 17). Ambas muestras tuvieron una disminución de aproximadamente $0,5 \log \mathrm{UFC} / \mathrm{g}$ luego de 40 días de almacenamiento. Pasado este tiempo, el descenso en la viabilidad fue más marcado para la muestra KUHTdir. Tras 90 días de almacenamiento, se observó que la disminución en la viabilidad de bacterias lácticas para la muestra KWPdir fue menor a 1,5 log UFC/g, mientras que para KUHTdir fue significativamente superior y cercana a $2 \log$ UFC/g. Estos 
resultados parecieran mostrar que una mayor cantidad de sólidos disueltos en la suspensión de la muestra a secar tiene una influencia positiva en cuanto a la viabilidad de bacterias lácticas durante el almacenamiento.

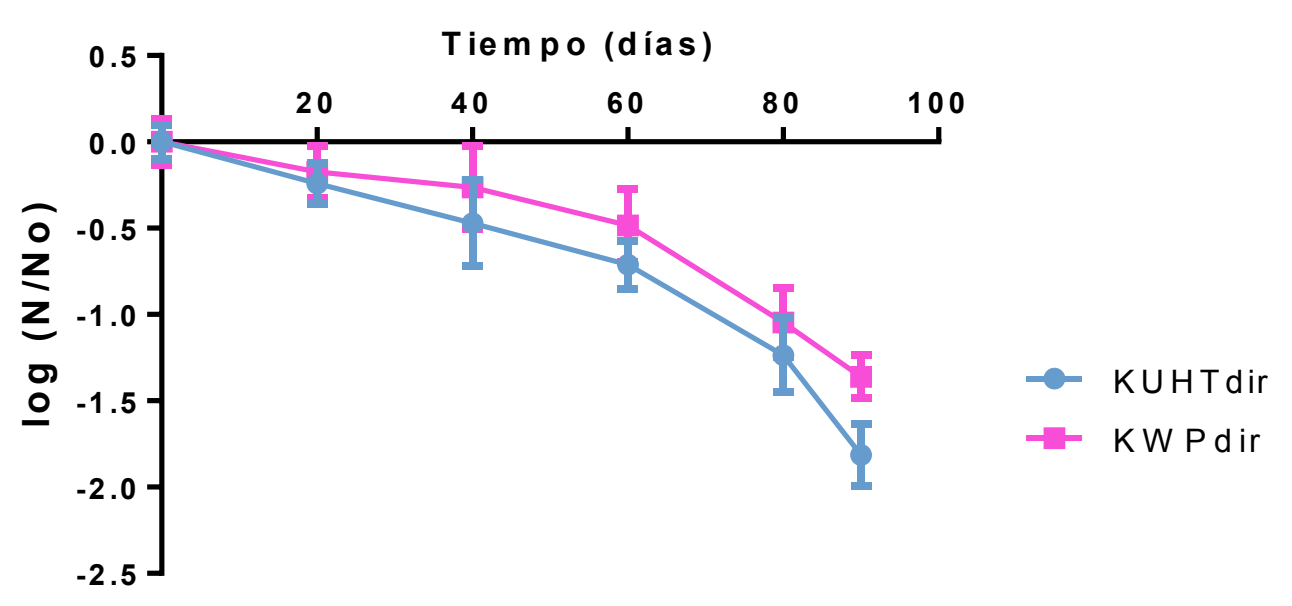

Figura 17: Supervivencia de bacterias lácticas viables en los productos elaborados mediante secado directo (ver Tabla Referencia de Muestras) durante el almacenamiento a $4^{\circ} \mathrm{C}$. Las barras corresponden a la desviación estándar. Los valores graficados corresponden a 3 experimentos independientes.

Con respecto al comportamiento de las levaduras presentes en los productos deshidratados durante el almacenamiento observamos que para KWPdir la viabilidad de las levaduras disminuyó marcadamente y a los 40 días de almacenamiento ya no fueron detectables (datos no mostrados). Por su parte, en el producto deshidratado obtenido a partir de kefir directamente (KUHTdir) no se obtuvieron levaduras viables tras el proceso de secado spray, por lo tanto, no se pudieron realizar los estudios de almacenamiento para esta población.

Por su parte la aW de las muestras no se vio modificada durante los 90 días de almacenamiento, manteniéndose por debajo de 0,3 y $\sin$ modificaciones significativas respecto de los valores de aW al comenzar el ensayo (Figura 18). 


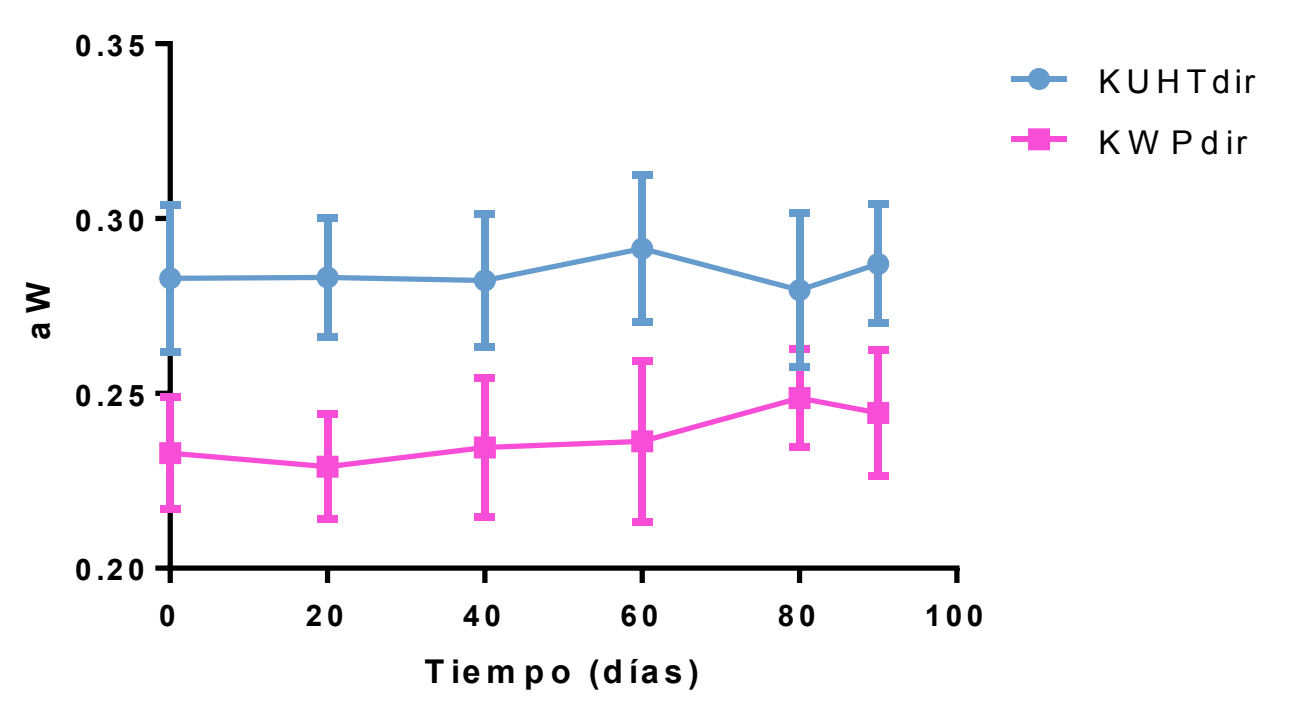

Figura 18: Medida de la actividad de agua de los productos obtenidos mediante secado directo (ver Tabla Referencia de Muestras) durante su almacenamiento a $4^{\circ} \mathrm{C}$. Los resultados graficados corresponden al promedio de por lo menos tres ensayos independientes. Las barras corresponden a la desviación estándar.

\subsubsection{Muestras obtenidas por secado utilizando carriers}

Las muestras obtenidas utilizando diferentes carriers mostraron dos comportamientos diferentes en cuanto a la viabilidad de las bacterias lácticas durante los 90 días de almacenamiento. Por un lado, las muestras obtenidas con carriers neutralizados sufrieron un descenso muy importante en los primeros 20 días de almacenamiento, dicho descenso fue cercano a $3 \log$ UFC/g. Luego, la viabilidad de las bacterias lácticas en estas muestras se estabilizó hasta el final de la evaluación. En contraste, Romano y col. (2014) encontraron que la neutralización del carrier previo al proceso de secado mejoraba la estabilidad del producto durante el almacenamiento en lo que respecta a la viabilidad microbiana.

Como se puede observar en la Figura 19, cuando los carriers no fueron neutralizados se obtuvieron productos más estables desde el punto de vista de la viabilidad de las bacterias lácticas. Durante los primeros 60 días de ensayo la viabilidad no se modificó 
significativamente, pero luego de transcurrido dicho tiempo, la viabilidad comenzó a descender de un modo más pronunciado. Todas las muestras no neutralizadas mostraron un descenso de aproximadamente 1,3 log UFC/g transcurridos 90 días de ensayo. Reddy y col. (2009) observaron una disminución de la viabilidad promedio del $40 \%$ durante 60 días de almacenamiento a $4{ }^{\circ} \mathrm{C}$ para cepas probióticas secadas en spray utilizando leche descremada o maltodextrina $10 \% \mathrm{p} / \mathrm{v}$ como carrier. En este sentido, la pérdida de viabilidad de las muestras obtenidas fue sustancialmente menor que lo mostrado por Reddy y col. (2009).

El comportamiento durante el almacenamiento es un fenómeno multifactorial que depende no solamente del carrier utilizado para el secado o de las condiciones de almacenamiento, sino también de los microorganismos y las condiciones que éstos atraviesan durante todo el proceso. En este trabajo pudimos demostrar que la viabilidad durante el almacenamiento mejora cuando los microorganismos no son sometidos a cambios de $\mathrm{pH}$ antes del secado spray. Se podría suponer que la variación de $\mathrm{pH}$ representa un estrés adicional que deben sobrellevar los microorganismos, y que, si bien no tiene un efecto que se pueda observar inmediatamente finalizada la deshidratación, durante el posterior almacenamiento se manifiesta como una pérdida de la viabilidad de las bacterias lácticas. 


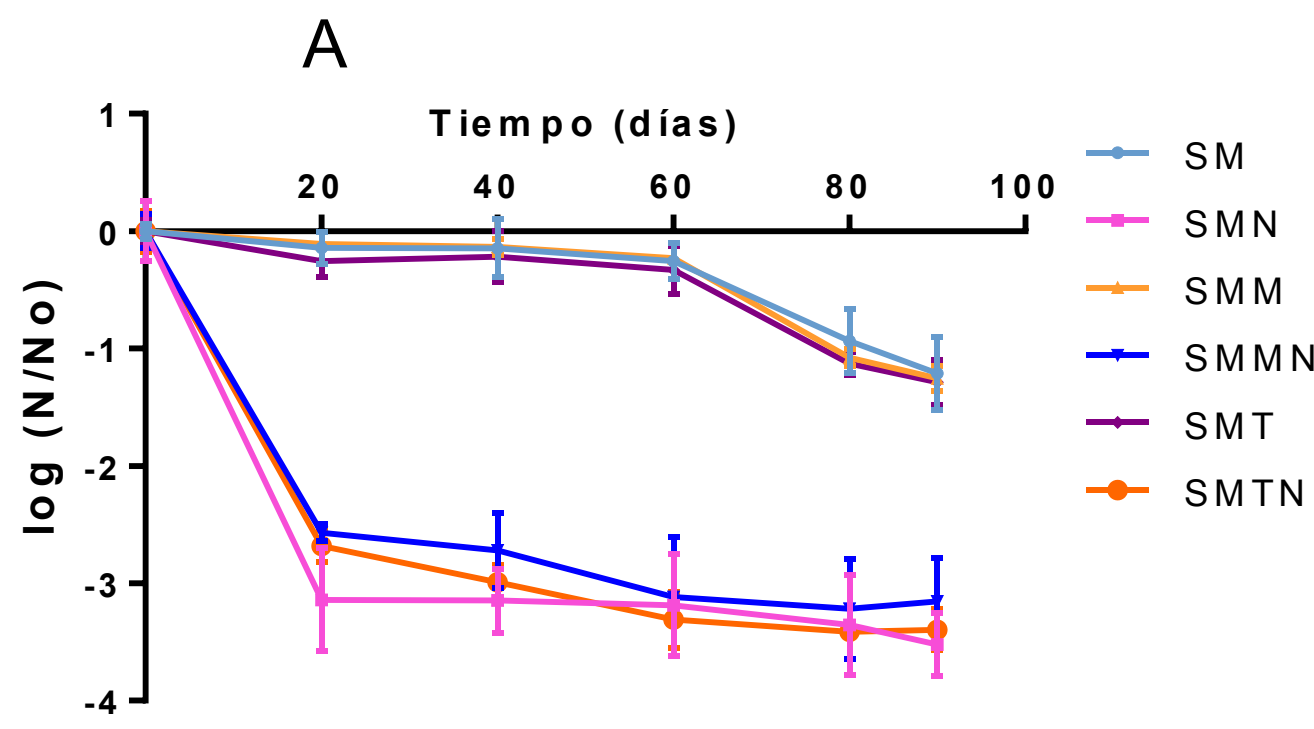

B

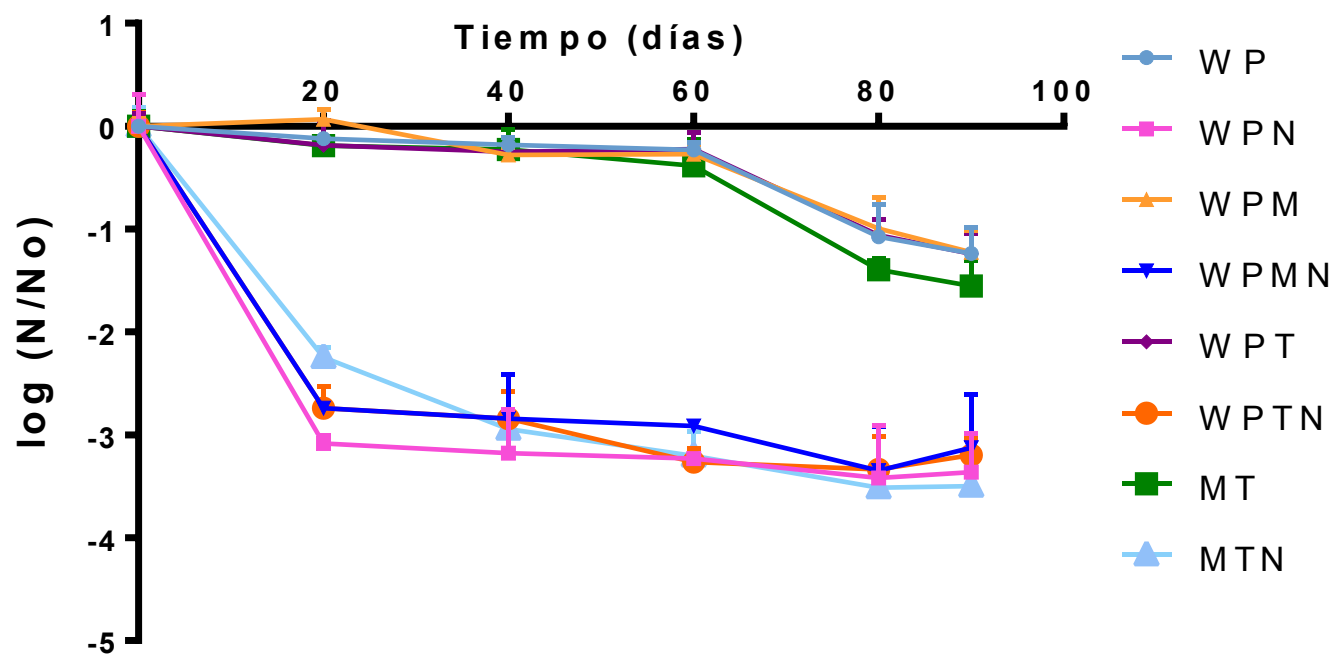

Figura 19: Supervivencia de bacterias lácticas viables en los productos elaborados mediante secado con carriers (Ver Tabla Resumen de Muestras) durante el almacenamiento a $4^{\circ} \mathrm{C}$. Para una mejor visualización, se muestran aquellos productos elaborados utilizando carriers que contienen leche descremada (A) y aquellos elaborados con carriers que no contienen leche descremada como componente (B). Las barras representan la desviación estándar. Los valores graficados corresponden a por lo menos 3 ensayos independientes. 
Con respecto a las levaduras viables presentes en la muestra, el comportamiento fue similar al descripto para las bacterias lácticas independientemente del carrier usado o de su neutralización. Observamos que luego de 20 días de almacenamiento, aquellas muestras que poseían levaduras viables pierden alrededor de $3 \log \mathrm{UFC} / \mathrm{g}$, lo que representa una pérdida superior al $60 \%$ de la cantidad inicial de levaduras (Figura 20). A los 40 días de almacenamiento las levaduras no son detectadas en ninguna muestra independientemente del carrier utilizado para la deshidratación. Este fenómeno se debe principalmente a la baja tolerancia al estrés térmico por parte de las levaduras, como ya fue mencionado anteriormente, el cual genera daños irreparables que se evidencian como pérdida de viabilidad durante el almacenamiento. Chandralekha y col. (2016) observaron una pérdida de viabilidad similar durante los primeros 15 días de almacenamiento para Saccharomyces cerevisiae deshidratada por liofilización. Sin embargo, lograron disminuir significativamente la pérdida de viabilidad al deshidratar mediante secado spray utilizando como carriers almidón de maíz. Esta mejora en la viabilidad se debe a la selección de parámetros de secado que favorecen la supervivencia de dicho microorganismo, disminuyendo así el estrés térmico que deben soportar las levaduras durante la deshidratación (Chandralekha y col., 2016). 

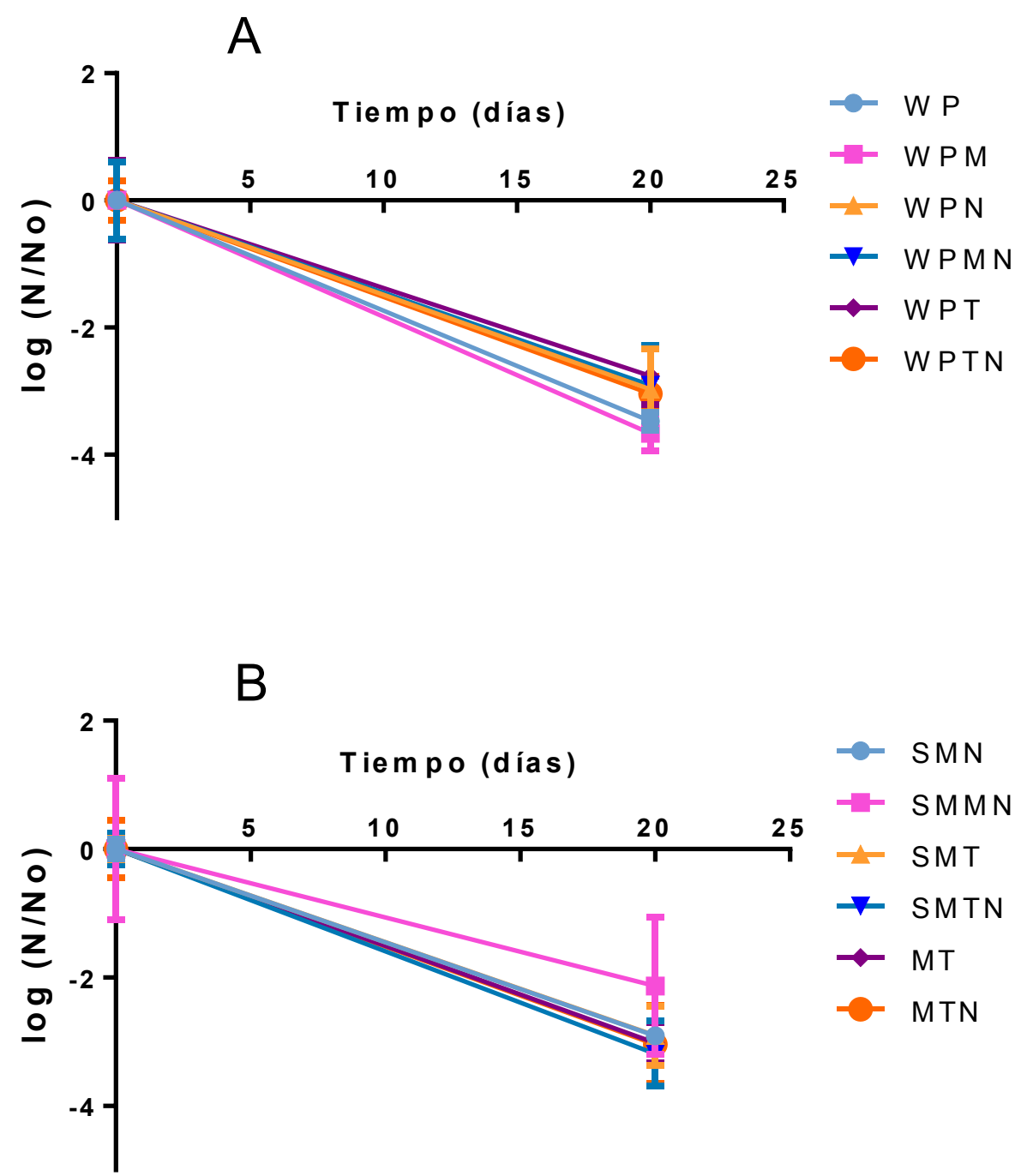

Figura 20: Supervivencia de levaduras viables en los productos elaborados mediante secado con carriers (Ver Tabla Resumen Muestras) durante el almacenamiento a $4^{\circ} \mathrm{C}$. Para una mejor visualización, se muestran aquellos productos elaborados utilizando carriers que contienen permeado de suero (A) y aquellos elaborados con carriers que no contienen permeado de suero como componente (B). Los productos SM y SMM no se muestran ya que no presentaron levaduras viables tras el secado spray. Después de los 40 días de ensayo no se encontraron levaduras viables en ninguna de las muestras. Los valores graficados corresponden a por lo menos 3 ensayos independientes. 
En lo que concierne a la actividad de agua de los productos deshidratados utilizando carriers, observamos un comportamiento muy estable durante el almacenamiento a $4{ }^{\circ} \mathrm{C}$. Si bien pueden encontrarse cambios en el valor de la aW durante el almacenamiento, éstos son insignificantes y refuerzan las afirmaciones en cuanto a la estabilidad del producto (Figura 21).

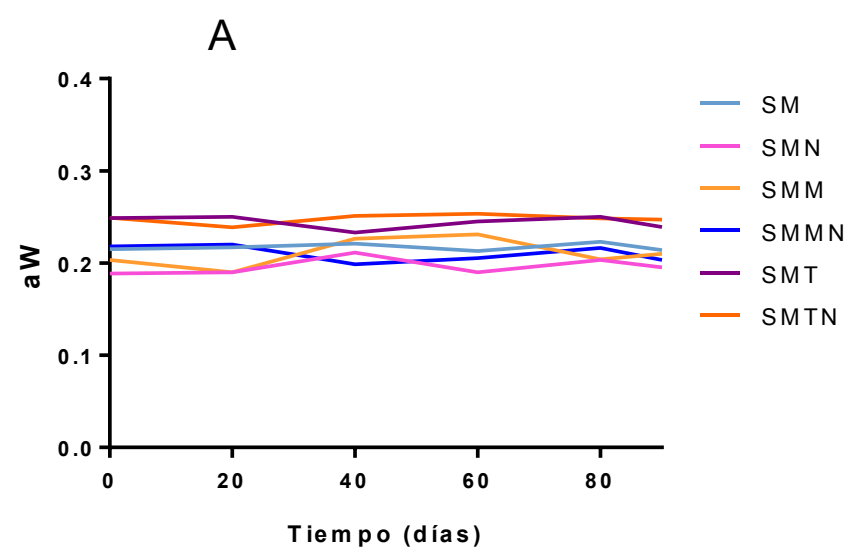

B

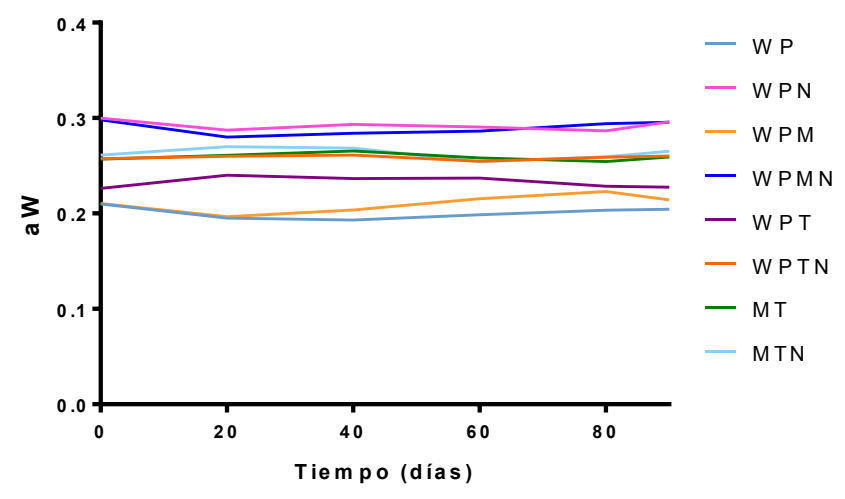

Figura 21: Valor de la actividad de agua de los productos elaborados mediante secado con carriers (Ver Tabla Resumen Muestras) durante el almacenamiento a $4^{\circ} \mathrm{C}$. Para una mejor visualización, se muestran aquellos productos elaborados utilizando carriers que contienen leche descremada (A) y aquellos elaborados con carriers que no contienen leche descremada como componente (B). Los valores graficados corresponden a por lo menos 3 ensayos independientes. 


\subsubsection{Secado spray a escala piloto}

Los resultados obtenidos a escala laboratorio alentaron a realizar estudios de escalado en el marco de una posible aplicación industrial.

Al escalar un proceso de secado spray, el objetivo debe ser mantener constantes los parámetros de proceso más importantes y ajustar los que tienen el menor impacto en el proceso. En un equipo secador spray, los parámetros clave del proceso en orden de importancia son la temperatura del aire de salida, el tamaño de las gotas y la concentración de vapor de agua a salida (Arpagaus y Schwartzbach, 2008).

Si bien la temperatura del aire de salida es el parámetro más importante a mantener constante durante el proceso de escalado, debido al cambio de equipamiento utilizado, las condiciones de secado tuvieron que ser modificadas. Cuando la temperatura de salida era inferior a 75 ${ }^{\circ} \mathrm{C}$, el producto no se logró secar por completo y terminaba adherido a las paredes de la cámara de secado. Esto se debió a que el equipo usado no permitía modificar el caudal de alimentación de la muestra líquida (que al aumentarse hace que la temperatura de salida disminuya).

Con respecto a los otros parámetros de relevancia, el tamaño de las gotas debió permanecer fijo ya que el equipo utilizado no permitía el cambio de tobera. La humedad en el polvo final está relacionada con la humedad en el aire que sale de la cámara de secado, es decir con la concentración de vapor de agua. Este parámetro, si bien puede calcularse de antemano utilizando la tasa de evaporación del agua y la tasa de flujo de aire total, fue determinado a través de mediciones de la actividad de agua de muestras obtenidas en diferentes condiciones, considerándose como aceptable un valor de aW inferior a 0,3.

Así se establecieron dos condiciones de secado: 1) Temperatura de entrada de $200{ }^{\circ} \mathrm{C}$, presión de gas de 3 bar y temperatura de salida de $75^{\circ} \mathrm{C}$ y 2) Temperatura de entrada de 
$210{ }^{\circ} \mathrm{C}$, presión de gas de 3 bar y temperatura de salida de $80{ }^{\circ} \mathrm{C}$. Para ver como la temperatura de salida influía en las características del producto.

Además de evaluar el escalado del proceso, se estudió el uso de otras sustancias como componentes de los carriers en combinación con leche descremada como glutamato monosódico, lactosa y sorbitol (Tabla 12).

Tabla 12: Carriers utilizados para el secado spray de kefir a escala piloto. La nomenclatura utilizada para el carrier se conserva como nombre del producto obtenido.

\begin{tabular}{|l|l}
\hline MTR & Descripción \\
\hline SM & Leche descremada $20 \% \mathrm{p} / \mathrm{v}, \mathrm{pH}=5.80$ \\
\hline SMM & Leche descremada $20 \% \mathrm{p} / \mathrm{v}+$ Maltodextrina $20 \% \mathrm{p} / \mathrm{v}$, partes iguales, $\mathrm{pH}=5.83$ \\
\hline SML & Leche descremada $20 \% \mathrm{p} / \mathrm{v}+$ Lactosa $20 \% \mathrm{p} / \mathrm{v}$, partes iguales, $\mathrm{pH}=5.75$ \\
\hline SMG & $\begin{array}{l}\text { Leche descremada } 20 \% \mathrm{p} / \mathrm{v}+\text { Glutamato monosódico } 20 \% \mathrm{p} / \mathrm{v}, \text { partes iguales, } \\
\mathrm{pH}=5,73\end{array}$ \\
\hline SMS & Leche descremada $20 \% \mathrm{p} / \mathrm{v}+$ Sorbitol $20 \% \mathrm{p} / \mathrm{v}$, partes iguales, $\mathrm{pH}=5,81$ \\
\hline
\end{tabular}

Es importante aclarar que el carrier SMS se probó solamente para la temperatura de salida de $80{ }^{\circ} \mathrm{C}$ debido a cuestiones de disponibilidad del equipo.

\subsubsection{Caracterización de los productos deshidratados}

Las características de los productos deshidratados elaborados a escala piloto con una temperatura de salida de $80{ }^{\circ} \mathrm{C}$ se detallan en la Tabla 13 , mientras que los obtenidos con una temperatura de salida de $75^{\circ} \mathrm{C}$ se resumen en la Tabla 14.

Los rendimientos porcentuales para todas las muestras, tanto para la temperatura de salida de $80{ }^{\circ} \mathrm{C}$ como para la de $75{ }^{\circ} \mathrm{C}$ fueron superiores al $40 \%$. Los valores máximos de rendimiento se obtuvieron cuando el carrier usado fue SMG (aproximadamente $50 \%$ ). Estos valores suponen un aumento considerable comparado con los obtenidos a escala laboratorio. 
El uso de un equipo de secado spray de dimensiones mayores permitió una menor adhesión de las partículas deshidratadas a las paredes de la cámara de secado y del ciclón, resultando en una mayor recuperación de la muestra. Además, al estar construido en acero inoxidable, el equipo puede ser golpeado suavemente por fuera para desprender el producto deshidratado de las paredes del equipo.

El uso de este equipo a escala piloto también explica el aumento del tamaño de partícula obtenido. Los tamaños de partícula promedio para las muestras obtenidas a escala piloto fueron en promedio de $27 \mu \mathrm{m}$. Este parámetro no se vio afectado por la modificación de la temperatura de salida o el tipo de carrier usado, y se relacionó fuertemente con las características del equipo utilizado, cuya tobera de dos fluidos genera partículas entre $20 \mathrm{y}$ $70 \mu \mathrm{m}$.

Como ya se mencionó, la actividad de agua de la muestra y el contenido de agua presente en la misma se relacionan con la vida útil del producto deshidratado. Todos los productos obtenidos con el secador spray escala piloto mostraron valores de aW menores o iguales a 0,3 y de humedad porcentual inferiores al $6 \%$. Estos valores se asemejaron a los obtenidos en el presente trabajo a escala laboratorio con un carrier sin neutralizar, y que, además, resultaron en un producto que demostró una baja pérdida de viabilidad de bacterias lácticas durante 60 días de almacenamiento a $4{ }^{\circ} \mathrm{C}$.

El recuento de bacterias lácticas viables en los productos obtenidos a una temperatura de salida de $80^{\circ} \mathrm{C}$ fue siempre superior a $9 \log \mathrm{UFC} / \mathrm{g}$, y no se observaron diferencias en este parámetro al disminuir la temperatura de salida en $5{ }^{\circ} \mathrm{C}$ o al modificar el tipo de carrier usado. Otros autores, como Slavutsky y col. (2016), tampoco reportaron diferencias en cuanto a la viabilidad microbiológica al disminuir en $5{ }^{\circ} \mathrm{C}$ la temperatura de salida en ensayos realizados a escala piloto. 
Tabla 13: Características de los productos deshidratados obtenidos por secado spray a escala piloto y con una temperatura de salida de $80{ }^{\circ} \mathrm{C}$ utilizando los diferentes carriers. Ver Tabla Referencia de Muestras. Los valores resumidos en la tabla muestran los resultados de por lo menos tres experimentos independientes.

\begin{tabular}{|c|c|c|c|c|c|c|c|c|c|c|c|c|}
\hline \multirow[t]{2}{*}{ Producto } & \multicolumn{2}{|c|}{ Rendimiento (\%) } & \multicolumn{2}{|c|}{$\mathrm{aW}$} & \multicolumn{2}{|c|}{ Humedad (\%) } & \multicolumn{2}{|c|}{$\begin{array}{c}\text { Bacterias Lácticas } \\
\text { (log UFC/g) }\end{array}$} & \multicolumn{2}{|c|}{$\begin{array}{c}\text { Levaduras (log } \\
\text { UFC/g) }\end{array}$} & \multicolumn{2}{|c|}{$\begin{array}{c}\text { Tamaño partícula } \\
\text { promedio }(\mu \mathrm{M})\end{array}$} \\
\hline & Media & DS & Media & DS & Media & DS & Media & SD & Media & SD & Media & DS \\
\hline SM & 45,94 & 3,8 & 0,29267 & 0,01 & 5,75 & 0,21 & 9,2 & 0,3 & 0 & 0 & 27,54 & 4,3 \\
\hline SMM & 42,43 & 4,1 & 0,26581 & 0,01 & 5,64 & 0,31 & 9,3 & 0,3 & 1,1 & 0,6 & 28,60 & 4,6 \\
\hline SML & 43,24 & 2,9 & 0,27314 & 0,02 & 5,42 & 0,27 & 9,4 & 0,2 & 2,2 & 0,8 & 26,31 & 4,2 \\
\hline SMG & 49,46 & 3,8 & 0,27912 & 0,02 & 5,79 & 0,31 & 9,1 & 0,2 & 4,6 & 0,7 & 27,93 & 3,9 \\
\hline SMS & 40,27 & 4,0 & 0,30102 & 0,02 & 6,93 & 0,32 & 9,1 & 0,3 & 4,3 & 0,6 & 29,87 & 5 \\
\hline
\end{tabular}


Tabla 14: Características de los productos deshidratados obtenidos por secado spray a escala piloto y con una temperatura de salida de $75^{\circ} \mathrm{C}$ utilizando los diferentes carriers. Ver Tabla Referencia de Muestras. Los valores resumidos en la tabla muestran los resultados de por lo menos tres experimentos diferentes.

\begin{tabular}{|c|c|c|c|c|c|c|c|c|c|c|c|c|}
\hline \multirow[t]{2}{*}{ Producto } & \multicolumn{2}{|c|}{ Rendimiento (\%) } & \multicolumn{2}{|c|}{ aW } & \multicolumn{2}{|c|}{ Humedad (\%) } & \multicolumn{2}{|c|}{$\begin{array}{c}\text { Bacterias Lácticas } \\
\text { (log UFC/g) }\end{array}$} & \multicolumn{2}{|c|}{$\begin{array}{c}\text { Levaduras (log } \\
\text { UFC/g) }\end{array}$} & \multicolumn{2}{|c|}{$\begin{array}{c}\text { Tamaño partícula } \\
\text { promedio ( } \mu \mathrm{M})\end{array}$} \\
\hline & Media & DS & Media & DS & Media & DS & Media & SD & Media & SD & Media & DS \\
\hline SM & 46,47 & 3,6 & 0,29851 & 0,01 & 5,81 & 0,17 & 9,2 & 0,3 & 0 & 0 & 26,97 & 4,2 \\
\hline SMM & 42,70 & 3,1 & 0,27486 & 0,02 & 5,80 & 0,2 & 9,3 & 0,3 & 2,2 & 0,7 & 28,80 & 4,4 \\
\hline SML & 42,16 & 2,5 & 0,27395 & 0,01 & 5,58 & 0,24 & 9,3 & 0,2 & 4,1 & 0,9 & 26,12 & 4,3 \\
\hline SMG & 50,16 & 4,3 & 0,28013 & 0,02 & 6,00 & 0,12 & 9,1 & 0,2 & 4,3 & 0,7 & 28,09 & 4,2 \\
\hline
\end{tabular}


Los resultados obtenidos en cuanto a las características de los productos deshidratados demostraron que el escalado del proceso es posible, con un aumento en el rendimiento y sin cambios en la viabilidad de los microorganismos evaluados. Este resultado es relevante ya que el escalado de los procesos representa uno de los principales desafíos a la hora de pensar una producción industrial de este tipo de alimentos (Huang, 2017).

Del mismo modo que cuando se utilizó el secador a escala laboratorio, no se lograron obtener levaduras viables en los productos SM a ninguna de las dos temperaturas analizadas. Para los productos obtenidos con los otros carriers fue posible detectar levaduras viables, pero en cantidades muy bajas con respecto a la leche fermentada obtenida de modo tradicional. Luna-Solano y col. (2005) lograron optimizar las variables para obtener valores de viabilidad de levaduras superiores a $6 \log \mathrm{UFC} / \mathrm{g}$ en un producto deshidratado por secado spray en un equipo escala piloto similar al usado en el presente trabajo. Sin embargo, realizar comparaciones resulta bastante complejo debido a la diferencia en los materiales de partida y las condiciones de operación del equipo.

\subsubsection{Análisis multivariante de componentes principales}

Para visualizar mejor los datos obtenidos de la caracterización de los distintos productos elaborados a escala piloto, se procedió nuevamente a un análisis multivariante de componentes principales.

Para el análisis multivariante de los productos obtenidos a escala piloto, se procedió de la misma manera que para las muestras obtenidas a escala laboratorio. En este caso particular, se analizaron en conjunto los productos obtenidos a las dos temperaturas de salida seleccionadas $\left(75\right.$ y $\left.80^{\circ} \mathrm{C}\right)$ con el fin de establecer si existe una influencia de la temperatura en los parámetros evaluados. Para poder visualizar esto de un modo amigable en los biplot, se modificó ligeramente la nomenclatura de los productos: $\mathrm{SM}$ obtenido a $\mathrm{T}$ salida $=80{ }^{\circ} \mathrm{C}$ 
pasó a ser SM80, mientras que el SM obtenido a $\mathrm{T}$ salida $=75^{\circ} \mathrm{C}$ pasó a ser SM75 y así sucesivamente con todos los productos.

Para este nuevo análisis, y como se puede ver en los rótulos de los ejes de los biplot, los primeros 3 componentes principales permiten explicar la mayor parte $(90 \%)$ de la variación. La matriz de correlación de probabilidades entre las variables y las correlaciones entre las variables evaluadas y los distintos componentes principales se muestran en las Tablas $15 \mathrm{y}$ 16 respectivamente. En este caso, CP1 se relacionó fuertemente con aW, humedad porcentual y tamaño de partícula, y negativamente con el número de bacterias viables; CP2 se relacionó fuertemente con el rendimiento y negativamente con el tamaño de partícula y el número de bacterias lácticas viables; y $\mathrm{CP} 3$, por su parte, se relacionó fuertemente con el número de levaduras viables y negativamente con la aW.

Tabla15: Matriz de correlación entre las distintas variables evaluadas para los productos deshidratados utilizando carriers a escala piloto.

\begin{tabular}{|c|c|c|c|c|c|c|}
\hline & $\begin{array}{l}\text { Bacterias } \\
\text { lácticas } \\
\text { (log UFC/g) }\end{array}$ & aW & $\begin{array}{l}\text { Humedad } \\
(\%)\end{array}$ & $\begin{array}{c}\text { Levaduras } \\
\text { (log } \\
\text { UFC/g) }\end{array}$ & $\begin{array}{c}\text { Tamaño } \\
\text { Partícula } \\
\text { (um) }\end{array}$ & $\begin{array}{l}\text { Rendimiento } \\
\text { (\%) }\end{array}$ \\
\hline $\begin{array}{c}\text { Bacterias } \\
\text { lácticas } \\
(\log \text { UFC/g) }\end{array}$ & & & & & & \\
\hline aW & 0,0743 & & & & & \\
\hline Humedad (\%) & 0,0446 & 0,0518 & & & & \\
\hline $\begin{array}{l}\text { Levaduras (log } \\
\text { UFC/g) }\end{array}$ & 0,3279 & 0,6922 & 0,3078 & & & \\
\hline $\begin{array}{c}\text { Tamaño } \\
\text { Partícula }(\mu \mathrm{m})\end{array}$ & 0,2124 & 0,5374 & 0,0176 & 0,5958 & & \\
\hline $\begin{array}{c}\text { Rendimiento } \\
(\%)\end{array}$ & 0,1414 & 0,887 & 0,5834 & 0,8372 & 0,6345 & \\
\hline
\end{tabular}


Tabla 16: Correlación de las variables evaluadas con los componentes principales generados por el análisis de los datos para los productos deshidratados utilizando carriers a escala piloto.

\begin{tabular}{|c|c|c|c|c|c|c|}
\hline Variables & $\mathrm{CP} 1$ & $\mathrm{CP} 2$ & $\mathrm{CP} 3$ & $\mathrm{CP} 4$ & $\mathrm{CP5}$ & $\mathrm{CP6}$ \\
\hline Bacterias lácticas (log UFC/g) & $-0,87$ & $-0,46$ & 0,01 & $-0,03$ & 0,15 & 0,02 \\
\hline aW & 0,7 & 0,06 & $-0,64$ & $-0,31$ & 0,08 & $-0,04$ \\
\hline Humedad (\%) & 0,94 & $-0,31$ & 0,01 & $-0,1$ & 0,01 & 0,08 \\
\hline Levaduras (log UFC/g) & 0,4 & 0,09 & 0,85 & $-0,32$ & 0,05 & $-0,03$ \\
\hline Tamaño Partícula ( $\mathbf{\mu m})$ & 0,73 & $-0,41$ & 0,14 & 0,53 & 0,05 & $-0,03$ \\
\hline Rendimiento (\%) & 0,11 & 0,96 & 0,02 & 0,23 & 0,09 & 0,03 \\
\hline
\end{tabular}

Primeramente se observó si existía alguna relación entre la variación de los productos que se elaboraron con el mismo carrier a las diferentes temperaturas ensayadas. Si observamos los diferentes biplot (Figuras 22, 23 y 24), podemos ver que estas muestras se encontraron siempre agrupadas, es decir, SM80 (carrier SM obtenida a T salida $=80^{\circ} \mathrm{C}$ ) aparece en todos los gráficos cercana a SM75 (carrier SM obtenida a T salida $=75{ }^{\circ} \mathrm{C}$ ), fenómeno que se repitió con todas las muestras (excepto para SMS que solo se obtuvo a T salida $=80^{\circ} \mathrm{C}$ ). Esta observación nos permitió concluir que no existe una gran variación entre las muestras obtenidas con temperatura de salida de $80{ }^{\circ} \mathrm{C}$ o de $75^{\circ} \mathrm{C}$ cuando la composición del carrier es la misma, indicando que este cambio en la temperatura de salida es menos influyente que la composición de los carriers para los parámetros evaluados en los productos.

A diferencia de lo observado para las muestras obtenidas a escala laboratorio, si observamos los biplot CP1 vs CP2 y CP1 vs CP3 (Figuras 22 y 23), podemos notar que la variable bacterias lácticas viables no tuvo correlación con el rendimiento porcentual. Este fenómeno puede deberse a una menor termoprotección por parte de aquellas sustancias carriers que resultaron en mayor rendimiento del proceso. Por su parte, en dichos biplot, la aW, la humedad porcentual y el tamaño de partícula mostraron una relación positiva, al igual que 
lo observado a escala laboratorio, lo que indica que el cambio de escala del proceso no modifica la relación entre estas variables.

Refinando el análisis para los diferentes carriers empleados, en el caso de SM podemos ver en los biplot $\mathrm{CP} 1$ vs $\mathrm{CP} 2$ y $\mathrm{CP} 1$ vs $\mathrm{CP} 3$ (Figuras 22 y 23, respectivamente) que la muestra obtenida con $\mathrm{T}$ salida $=80{ }^{\circ} \mathrm{C}$ se posicionó hacia valores más negativos de $\mathrm{CP} 1$ con respecto a la obtenida a $75^{\circ} \mathrm{C}$. Esto se debió a que la cantidad de bacterias lácticas (que correlaciona con valores negativos de CP1) fue mayor para el producto obtenido a $80{ }^{\circ} \mathrm{C}$. Si se observa el biplot $\mathrm{CP} 2$ vs CP3 (Figura 24), vemos que ambas se encuentran en la mitad inferior del gráfico, que corresponde a valores negativos de CP3, debido a que ninguna de las muestras contenía levaduras viables, que es la variable que mayor correlación tuvo con este componente principal; mientras que la diferencia en la proyección sobre el eje CP2 se debió a para el producto obtenido a $75^{\circ} \mathrm{C}$ el rendimiento fue mayor.

Para las muestras SMM, ambas se proyectaron sobre valores negativos de CP1 (Figura 22), debido a que su cantidad de bacterias lácticas fue superior a la media de las muestras, sin embargo, el producto obtenido a $80{ }^{\circ} \mathrm{C}$ se proyectó hacia valores más negativos debido a menor contenido de humedad (que es la variable que mostró mayor correlación con este componente principal). Más aún, si se observa el biplot CP2 vs CP3 (Figura 24), estas muestras se proyectaron en puntos muy cercanos en el plano, lo que indica que la variabilidad entre ellas se debió principalmente al contenido porcentual de humedad, la variable con más peso sobre CP1.

Las muestras SML se proyectaron también a valores negativos de CP1, lo que se correspondió con el hecho de que la cantidad de bacterias lácticas viables en la muestra fue superior a la media; mientras que su proyección sobre CP2 fue similar (Figura 22), debido a que los valores observados para las variables que se correlacionan con este componente 
fueron muy similares para ambas muestras. Con respecto a CP3 (Figura 23), existió una pequeña diferencia a favor de la muestra obtenida a $75^{\circ} \mathrm{C}$, que se proyectó hacia valores más positivos de este componente debido a la diferencia en la cantidad de levaduras viables tras la deshidratación.

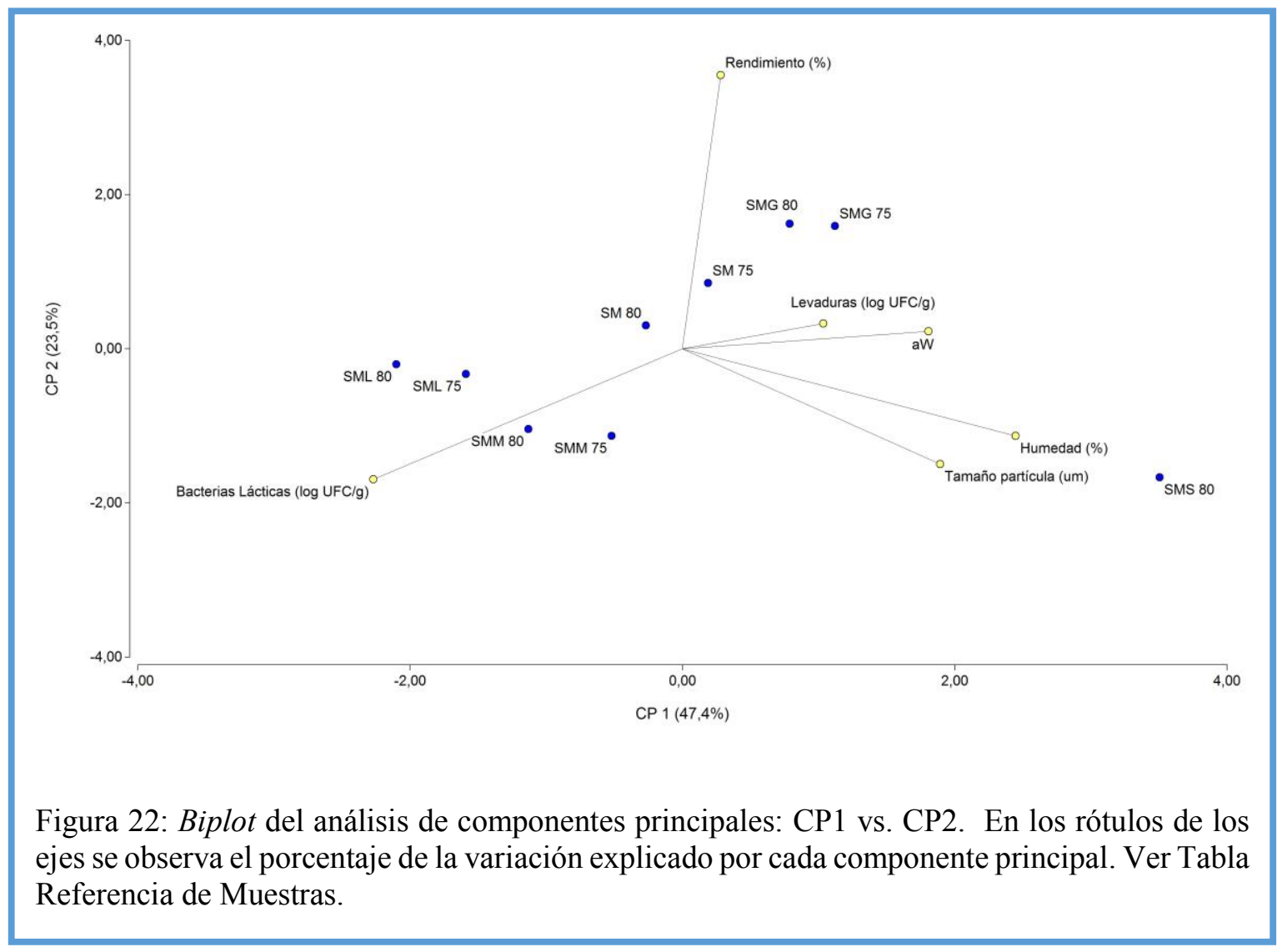



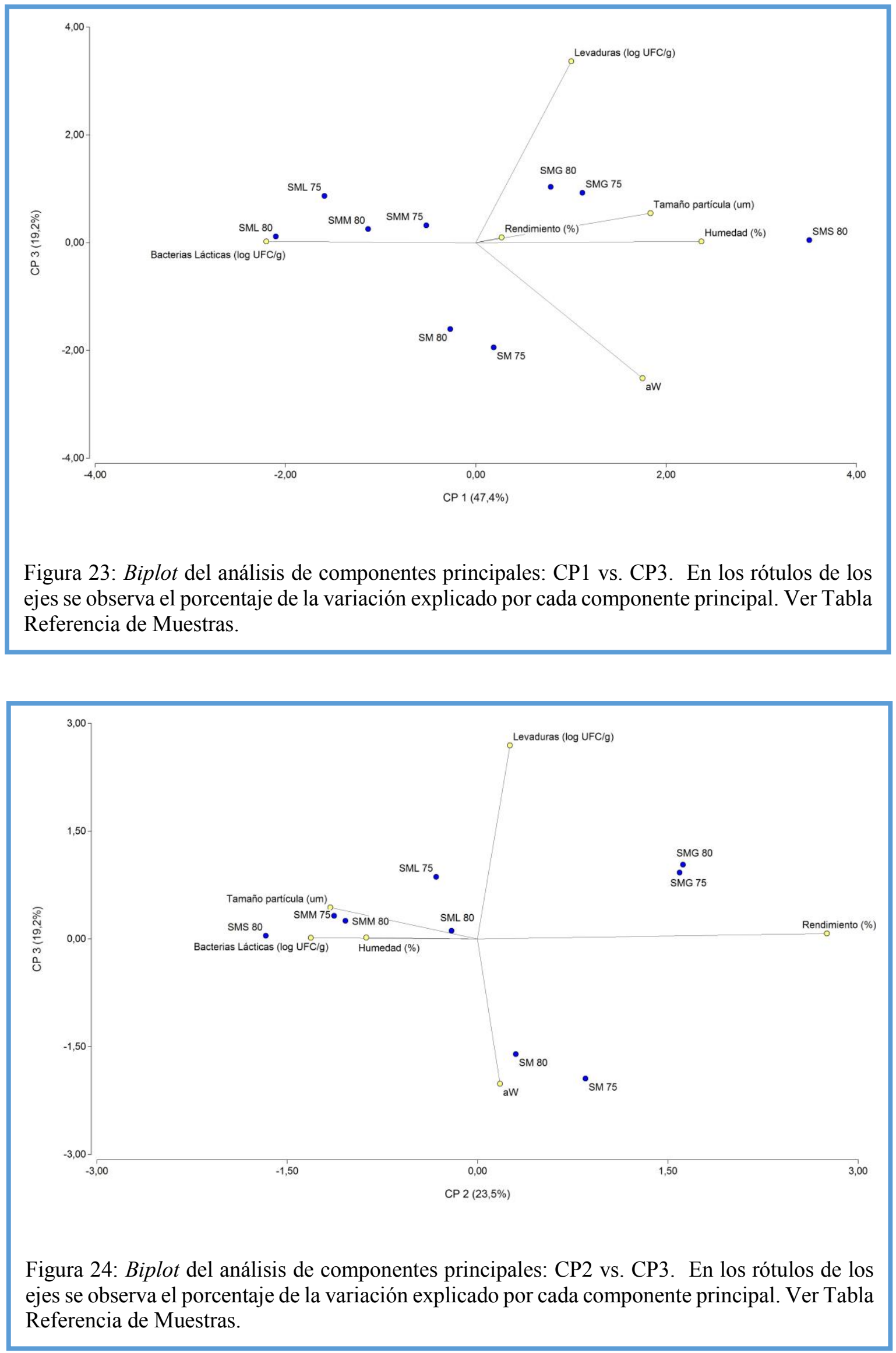
Ambas muestras SMG, por su parte, resultaron en un mayor rendimiento porcentual del proceso. Esto quedó claramente demostrado con su proyección hacia valores más positivos de CP2 que el resto de los productos. Además, el uso de leche descremada y glutamato monosódico como carrier resultó en un menor número de bacterias viables en el producto deshidratado, indicando que la protección térmica para las bacterias fue inferior que al utilizar otros carriers como por ejemplo SM, y explicando en parte la pérdida de la relación entre las variables rendimiento y viabilidad de bacterias lácticas observada a escala piloto. La diferencia en la proyección sobre CP1 entre ambas muestras SMG puede correlacionarse con diferencias en el contenido de humedad, lo que hizo que el producto obtenido a T salida $=75^{\circ} \mathrm{C}$, que posee un valor más elevado de este parámetro, se proyecte hacia valores más positivos de CP1 (Figura 22).

Finalmente, la muestra SMS80, mostró menor rendimiento y mayor humedad porcentual que la media de muestras (valores negativos de CP2 y positivos de CP1, respectivamente).Estas observaciones están íntimamente relacionadas ya que un producto más húmedo tiende a quedarse adherido a las paredes internas del equipo resultando en un menor rendimiento del proceso. Mientras que para CP3 no se observó una proyección muy alejada de la media debido a que el número de levaduras presente fue similar a la media de todas las muestras. De esta manera, vemos que para el secado a escala piloto la disminución de la temperatura de salida del proceso en $5^{\circ} \mathrm{C}$ tiene una influencia menor que la composición del carrier. Por otra parte, se observó una pérdida de la relación entre las variables rendimiento porcentual y viabilidad de bacterias lácticas respecto a lo observado a escala laboratorio, probablemente por el hecho de que los carriers que resultaron en mayor rendimiento ofrecieron una menor protección térmica a las bacterias.

Si bien las diferencias entre los productos obtenidos con los diferentes carriers son, a grandes rasgos, mínimas (excepto quizás por el contenido de humedad, que para SMS es 
sustancialmente elevada), se puede decir que el uso de leche descremada junto con lactosa o maltodextrina en el carrier maximizó la viabilidad de bacterias lácticas y generó una menor aW en el producto final, lo que indica que estos 2 carriers serían los mejores para obtener un producto con las características óptimas respecto a los parámetros evaluados en este análisis.

\subsubsection{Actividad acidificante y actividad inhibitoria de Salmonella.}

Al igual que para escala laboratorio, los productos deshidratados obtenidos a escala piloto se utilizaron para inocular leche y comprobar su actividad acidificante.

Como se puede observar en la Figura 25, todos los productos son capaces de acidificar la leche alcanzando un pH menor a 5 tras $24 \mathrm{hs}$ de incubación a temperatura ambiente. Este comportamiento es muy parecido al observado con los productos obtenidos a escala laboratorio, lo que refuerza aún más la robustez del método y la factibilidad del escalado.

En las Figuras 26 y 27 se pueden observar los diámetros de los halos de inhibición de los diferentes productos frente a 3 cepas de Salmonella. La presencia de microorganismos del kefir en el producto deshidratado incrementó el diámetro de inhibición para todas las muestras y frente a cualquiera de las 3 serovariedades de Salmonella evaluadas. Además, el cambio en la temperatura de salida del producto de 80 a $75^{\circ} \mathrm{C}$ no se tradujo en una diferencia en la intensidad de inhibición. Al igual que para las muestras obtenidas a escala laboratorio, esta capacidad inhibitoria se atribuyó a la capacidad acidificante mostrada por los todos los productos elaborados. 

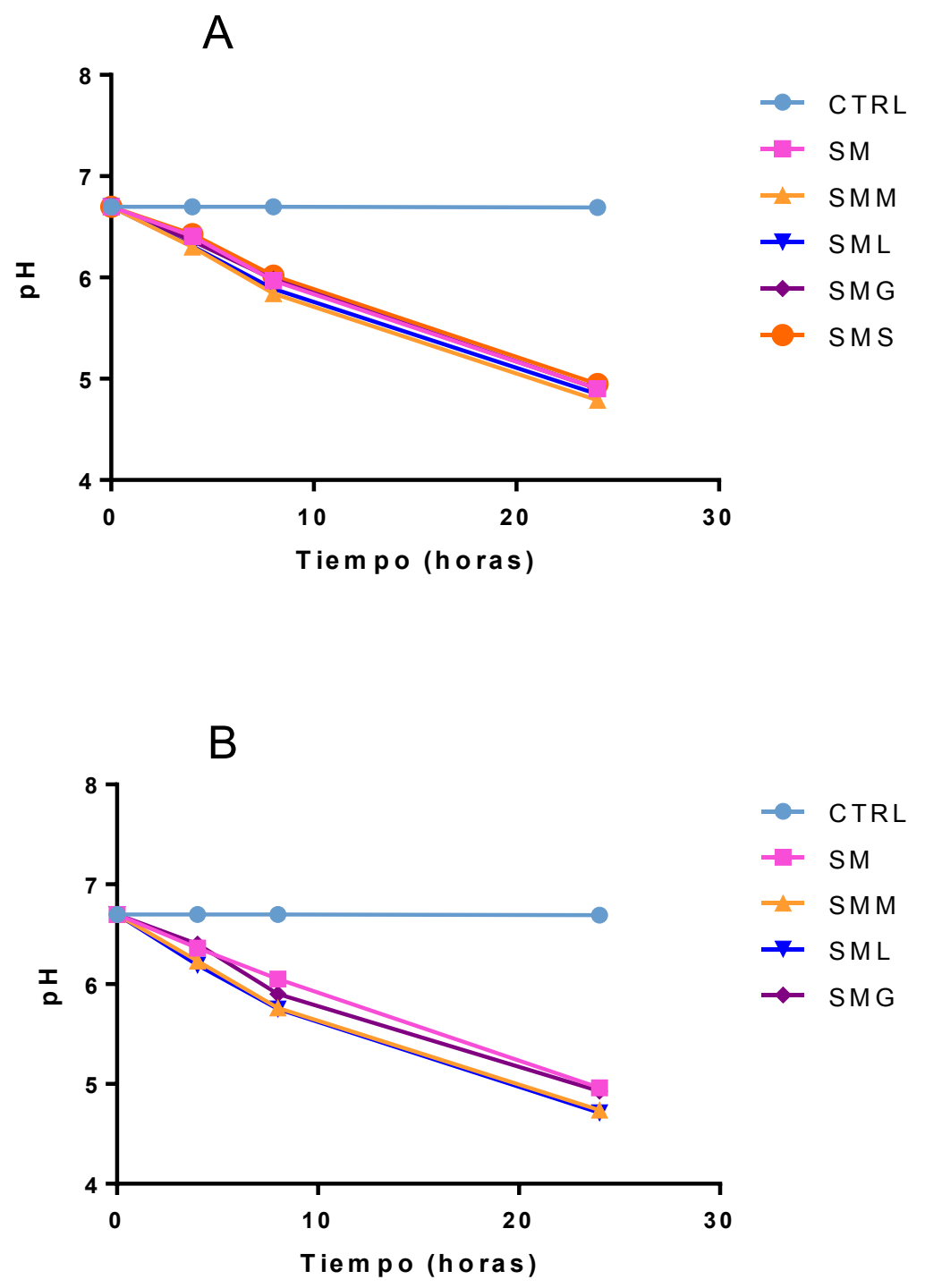

Figura 25: Disminución de pH en función del tiempo para leche UHT inoculada 10\% (p/v) con los diferentes productos obtenidos por secado spray a escala piloto (ver Tabla Referencia de Muestras), con temperatura de salida de $80^{\circ} \mathrm{C}$ (A) y de $75^{\circ} \mathrm{C}$ (B). Como control (CTRL) se utilizó leche UHT sin inocular.

Para verificar si existía un efecto antagónico frente a Salmonella por parte de los componentes del carrier, se elaboraron productos utilizando las mismas condiciones de secado pero sin dichos microorganismos. Esto nos permitió observar que algunas de las muestras sin microorganismos generan un halo de inhibición frente a este patógeno. Esto es notorio para el caso de SMG y SMS (independientemente de la temperatura a la que se 
obtuvo el producto). Para estos productos existe entonces una inhibición del crecimiento del patógeno que no se relaciona con la producción de ácidos orgánicos. Varios autores (Abbas y col., 2012; Bhuvaneswari y col., 2015) han reportado la capacidad tanto del sorbitol como del glutamato de inhibir el crecimiento de diferentes patógenos bacterianos, entre ellos Salmonella. En este sentido, los productos SMG y SMS incrementaron su capacidad inhibitoria del crecimiento de Salmonella cuando contenían los microorganismos del kefir capaces de producir ácidos orgánicos. 
A

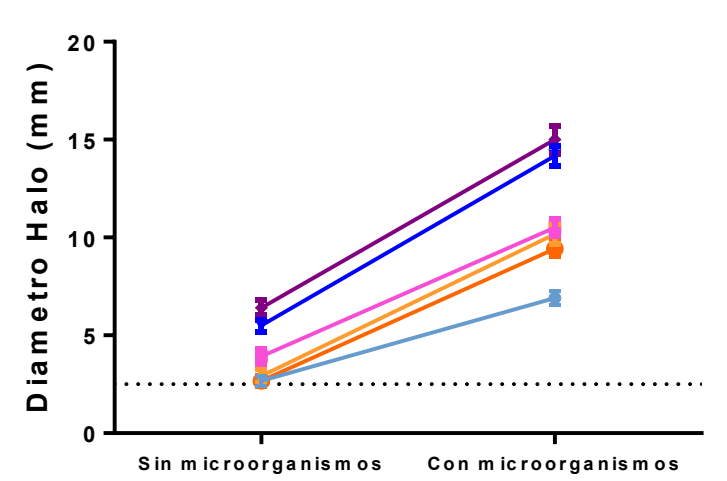

B

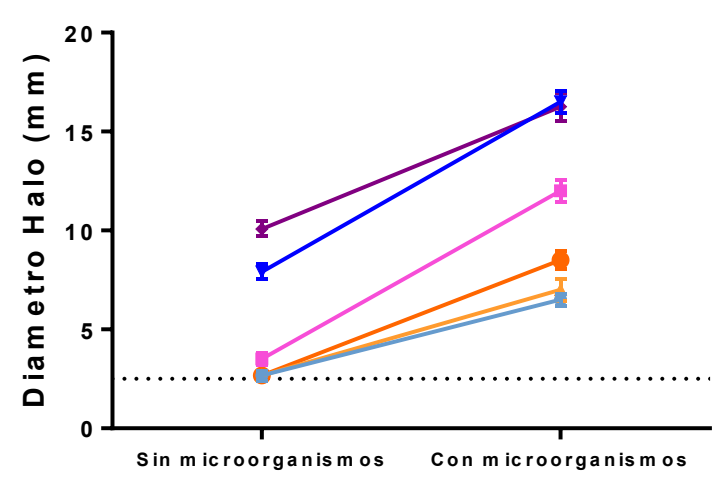

C

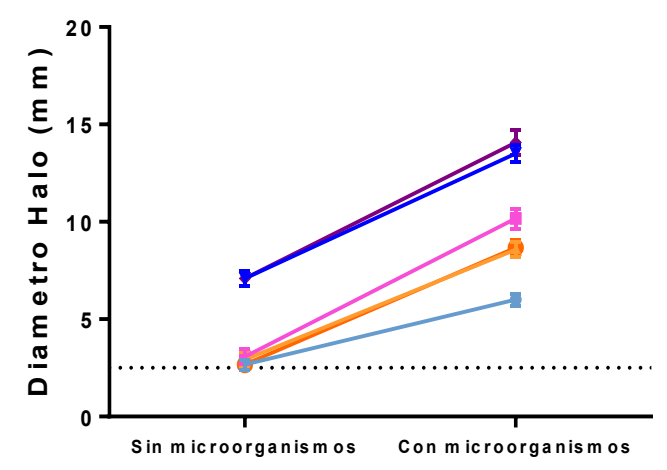

- Kefir Fresco

$\rightarrow$ SMS

- SMG

$=S M L$

$\rightarrow$ SMM

$\rightarrow$ SM

Figura 26: Diámetro de los halos de inhibición de los diferentes productos obtenidos con temperatura de salida de $80^{\circ} \mathrm{C}$ (Ver Tabla Resumen Muestras) versus tres cepas diferentes de Salmonella enterica serovar Enteritidis: SE105(A), SE106(B) y SE115(C); comparados con el kefir elaborado tradicionalmente (kefir fresco). En todos los casos, las muestras sin microorganismos hacen referencia al carrier sin los microorganismos del kefir, o a leche UHT para el caso del kefir fresco. La línea punteada corresponde al diámetro del well donde se colocó el producto deshidratado. Los valores graficados corresponden a por lo menos tres ensayos independientes. 
A

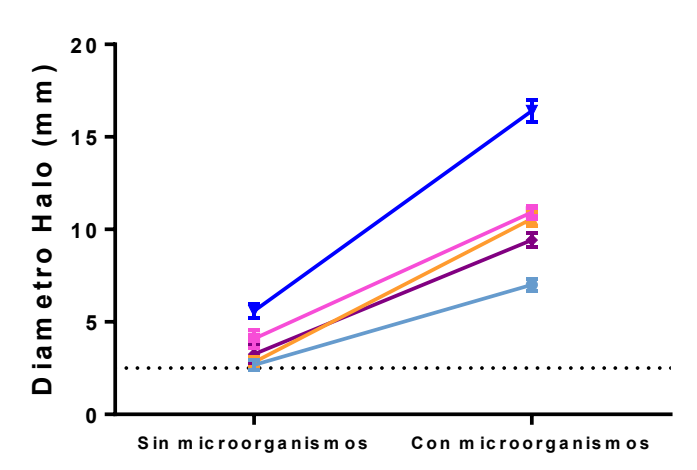

B

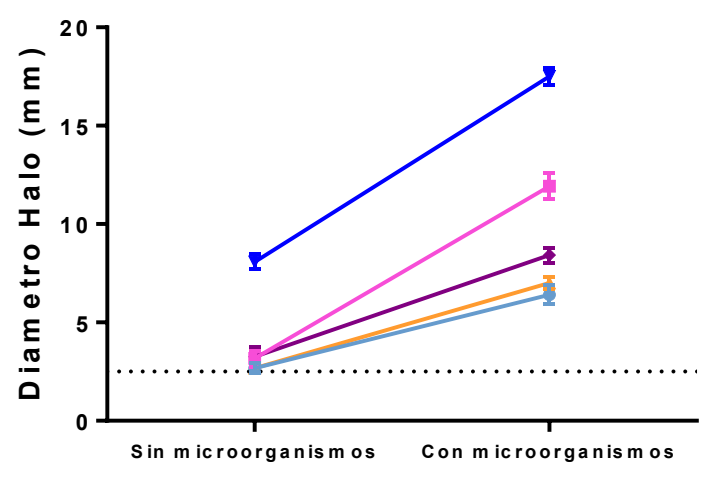

C

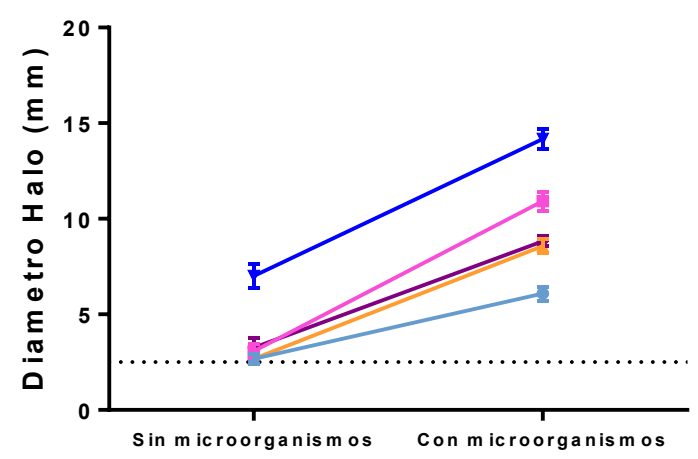

$\rightarrow$ Kefir Fresco

$\rightarrow$ SMG

$\simeq S M L$

- SMM

$\rightarrow S M$

Figura 27: Diámetro de los halos de inhibición de los diferentes productos obtenidos con temperatura de salida de $75^{\circ} \mathrm{C}$ (Ver Tabla Resumen Muestras) versus tres cepas diferentes de Salmonella enterica serovar Enteritidis: SE105(A), SE106(B) y SE115(C); comparados con el kefir elaborado tradicionalmente (kefir fresco). En todos los casos, las muestras sin microorganismos hacen referencia al carrier sin los microorganismos del kefir, o a leche UHT para el caso del kefir fresco. La línea punteada corresponde al diámetro del well donde se colocó el producto deshidratado. Los valores graficados corresponden a por lo menos tres ensayos independientes. 


\subsubsection{Evaluación de los ácidos orgánicos en los productos deshidratados}

Los ácidos orgánicos producidos por el metabolismo de las bacterias lácticas son considerados como factores antimicrobianos. Estudios realizados con kefir mostraron que la presencia de los ácidos láctico y acético en dicho producto le confieren propiedades inhibitorias contra patógenos intestinales (Garrote y col. 2000).

Los ácidos orgánicos, en particular el ácido acético y el ácido láctico, poseen un fuerte efecto inhibitorio contra bacterias Gram-negativas, sin embargo sólo unos pocos autores sugieren que la producción de ácidos orgánicos es el único factor responsable de la actividad antagonista (Fooks y Gibson, 2002, 2003). En otros reportes se ha sugerido la existencia de otras sustancias inhibitorias que pueden también contribuir a dicha actividad (Servin, 2004).

Si bien en el presente trabajo se demostró que los productos deshidratados contenían microorganismos viables y con capacidad acidificante, es relevante conocer la cantidad de ácidos orgánicos presentes en los productos deshidratados a escala piloto. Esta información permitiría corroborar que la capacidad inhibitoria frente al crecimiento de Salmonella se debe mayoritariamente a la producción de ácidos orgánicos por parte de las bacterias lácticas presentes en la muestra durante el ensayo y no al arrastre de ácidos del producto original. Los microrganismos del kefir son capaces de producir diversos ácidos orgánicos, como ácido láctico, acético, butírico, propiónico y cítrico (Garrote y col., 2000; Güzel-Seydim y col., 2000; Leite y col., 2013). Para esta evaluación, sin embargo, se seleccionaron acético y láctico como objetivo del análisis. La elección del ácido láctico, además de ser uno de los ácidos presentes en mayor concentración en el kefir, se basó en sus ampliamente reportadas propiedades inhibitorias del crecimiento de Salmonella (Adams y col., 1988; Burin y col., 2014; De Keersmaecker y col., 2006; Mani-López y col, 2012; Mikołajczyk y col., 2002; Rubin y col., 1982); mientras que el ácido acético, pese a encontrarse en una menor concentración en el kefir, también posee comprobadas propiedades antagónicas frente a este 
patógeno (Adams y col., 1988; Al-Rousan y col., 2018; Burin y col., 2014; El Baaboua y col., 2018).

Como se puede observar en la Tabla 17, los productos deshidratados contienen cantidades de ácido acético y láctico significativamente inferiores al kefir elaborado tradicionalmente. Tanto los pasos de centrifugación y resuspensión como el proceso mismo de deshidratación contribuirían a esto. Un aumento en la temperatura de salida de la muestra se correlaciona con una menor cantidad de ambos ácidos en el producto final. Este resultado nos permite corroborar que el arrastre de ácidos durante el proceso es despreciable a la hora de evaluar la capacidad inhibitoria frente a Salmonella y establecer así, que esta inhibición observada se debe principalmente a la actividad acidificante durante el ensayo de los microorganismos presentes en la muestra.

Tabla 17: Cuantificación de ácidos láctico y acético presentes en una dilución 1/10 en agua milliQ de los distintos productos deshidratados (ver Tabla Referencia de Muestras) y en el kefir elaborado tradicionalmente (Kefir fresco).

\begin{tabular}{|c|c|c|c|}
\hline $\begin{array}{c}\text { Producto } \\
\text { Kefir fresco }\end{array}$ & $\begin{array}{c}\text { Temperatura Salida } \\
\left({ }^{\circ} \mathbf{C}\right)\end{array}$ & $\begin{array}{c}\text { Ácido láctico }(\mathrm{g} / \mathrm{L}) \\
\text { Ácido acético (g/L) }\end{array}$ \\
\hline SM & - & 12,3789 & 0,5434 \\
\hline SMM & 75 & 1,3719 & 0,0552 \\
\hline SML & 80 & 0,9514 & 0,0597 \\
\hline SMG & 75 & 1,8927 & 0,0461 \\
\hline & 80 & 1,1867 & 0,0461 \\
\hline SMS & 75 & 1,8465 & 0,0416 \\
\hline & 80 & 1,0903 & 0,0416 \\
\hline
\end{tabular}

Es destacable que pese a que las cantidades absolutas disminuyen, la relación ácido láctico/ ácido acético se encuentra conservada independientemente del carrier empleado para la deshidratación. Las diferencias existentes entre los diferentes carriers utilizados no es lo suficientemente importante como para profundizar en un estudio de la relación entre los ácidos orgánicos presentes y el carrier empleado. 
Los resultados obtenidos en cuanto a la cantidad de ácidos orgánicos en las muestras reafirman la hipótesis de que la presencia de microorganismos viables en el producto con capacidad acidificante es un requisito indispensable para asegurar la propiedad inhibitoria del crecimiento de Salmonella.

\subsubsection{Almacenamiento de los productos obtenidos a escala piloto}

La viabilidad de los probióticos en un producto deshidratado como los obtenidos en el presente trabajo está inversamente relacionada con la temperatura de almacenamiento. Esto se ha demostrado ampliamente en productos que contienen probióticos obtenidos mediante secado spray (Barbosa y col., 2015; Corcoran y col., 2004; Silva y col., 2002; Wang y col., 2004). Si bien una temperatura de almacenamiento baja se traduce en un aumento de la vida útil, el almacenamiento de un producto refrigerado se considera como un alto costo para la industria. De esta manera, para los productos obtenidos a escala piloto se decidió evaluar el almacenamiento a dos temperaturas: 4 y $20{ }^{\circ} \mathrm{C}$. Tal como se realizó para las muestras obtenidas a escala laboratorio, la evaluación durante el almacenamiento se centró en dos parámetros: viabilidad microbiana y actividad de agua.

Para el almacenamiento a $4{ }^{\circ} \mathrm{C}$, la viabilidad de bacterias lácticas disminuyó paulatinamente (hasta 0,5 unidades logarítmicas) hasta aproximadamente los 60 días de almacenamiento, en donde se produjo un descenso abrupto de entre 1 y 1,5 unidades logarítmicas respecto al valor inicial (Figura 28). Al final de los 90 días de almacenamiento la pérdida de viabilidad de bacterias lácticas promedio fue menor a $2 \log \mathrm{UFC} / \mathrm{g}$ respecto al valor inicial. Si bien este fue el comportamiento general de los productos deshidratados, podemos también resaltar que la presencia de sorbitol o glutamato en el carrier mejoró levemente la viabilidad microbiana ya que luego de los 60 días se observó un descenso menos abrupto. Con respecto 
a esta observación, podemos citar a Carvalho y col. (2002), quienes realizaron experimentos de liofilización usando glutamato y sorbitol $\mathrm{y}$, si bien no demostraron diferencias significativas durante su trabajo, se encontró que estos compuestos mejoraban la estabilidad

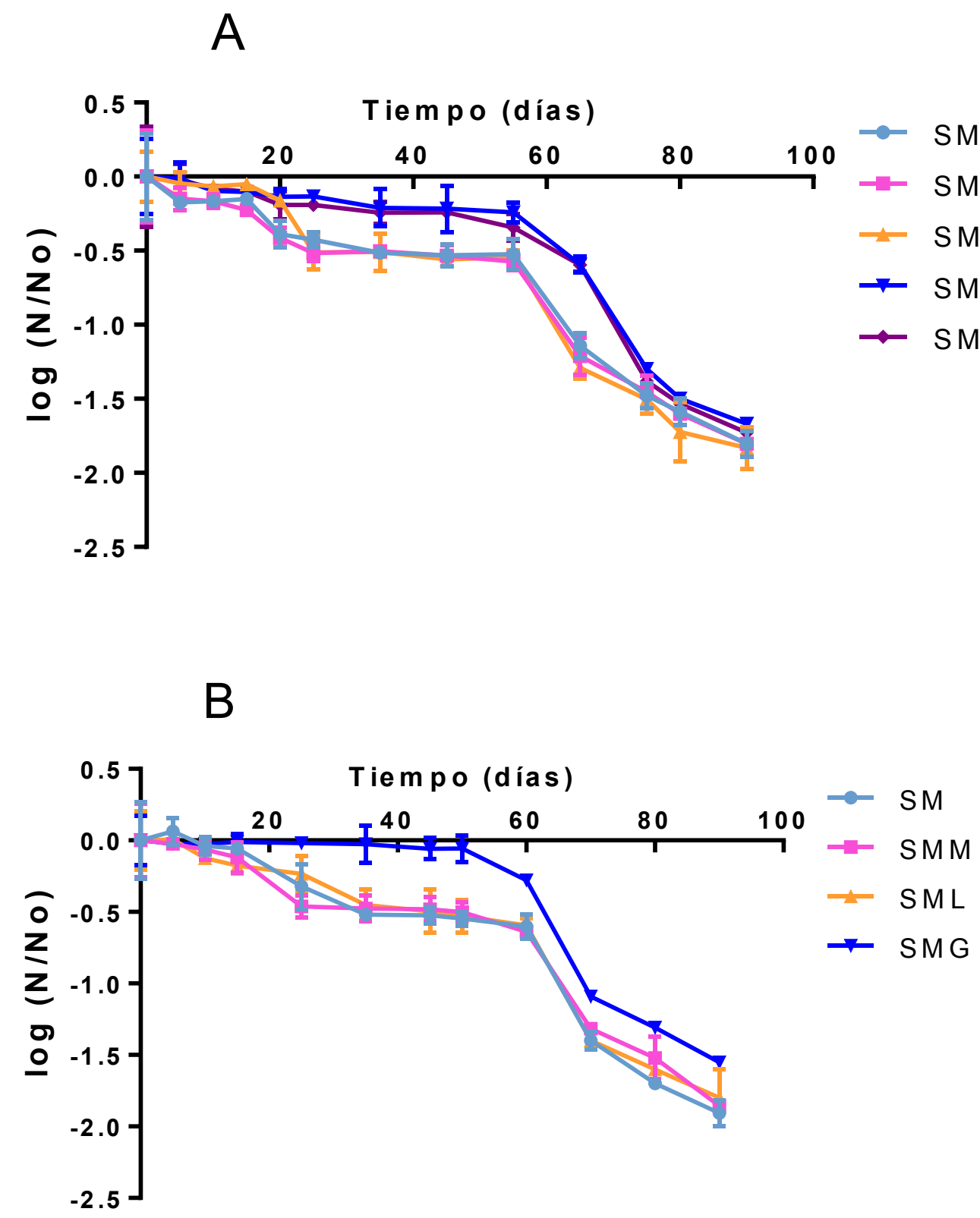

Figura 28: Supervivencia de bacterias lácticas viables en los productos deshidratados elaborados a escala piloto (Ver Tabla Resumen de Muestras) durante el almacenamiento a $4^{\circ} \mathrm{C}$. Para una mejor visualización, se muestran aquellos productos elaborados utilizando temperatura de salida de $80^{\circ} \mathrm{C}$ (A) y aquellos elaborados con temperatura de salida de $75^{\circ} \mathrm{C}$ (B). Los valores graficados corresponden a por lo menos dos ensayos independientes y las barras de error indican la desviación estándar entre las mediciones. 
de la mayoría de las cepas de bacterias lácticas evaluadas durante el almacenamiento a largo a plazo.

En cambio, cuando el almacenamiento se realizó a $20^{\circ} \mathrm{C}$, el comportamiento observado fue muy diferente (Figura 29). Durante los primeros 20 días los productos se mantuvieron relativamente estables con pérdida inferiores a 0,5 unidades logarítmicas respecto al número de microorganismos iniciales. Sin embargo, luego de este período de almacenamiento observamos una caída abrupta en la viabilidad microbiana para todas las muestras. Este descenso fue más leve para las muestras que contenían sorbitol o glutamato como componente del carrier, observándose un efecto atenuador en la perdida de viabilidad tal como se observó para el almacenamiento en frío. Sin embargo al final del almacenamiento todas las muestras (independientemente del carrier usado) mostraron un descenso de mayor a 3,5 log UFC/g respecto al número de microorganismos inicial.

La viabilidad de levaduras durante el almacenamiento mostro un comportamiento similar a las muestras obtenidas a escala piloto, y tras 30 días de ensayo no fue posible encontrar levaduras viables en las muestras almacenadas a $4{ }^{\circ} \mathrm{C}$. Esta pérdida de viabilidad fue más marcada para los productos almacenados a $20^{\circ} \mathrm{C}$, en los cuales no se encontraron levaduras viables tras 15 días de ensayo (datos no mostrados).

De estos resultados se desprenden dos conclusiones de importancia. Primero, que la producción de kefir deshidratado a escala piloto es factible y que el comportamiento de los productos durante su almacenamiento a $4{ }^{\circ} \mathrm{C}$ es estable durante casi dos meses. Segundo, que el almacenamiento a $20^{\circ} \mathrm{C}$ es lo suficientemente estable durante 20 días, pero luego las bacterias lácticas del producto pierden viabilidad muy rápidamente, con lo cual deberían buscarse estrategias para aumentar su vida útil en condiciones de almacenamiento que no resulten costosas para la industria. Una estrategia evaluada fue la adición de glutamato o 
sorbitol al carrier pero el efecto producido por estos no es suficiente como para mantener una elevada viabilidad de bacterias lácticas más allá de los 20 días.

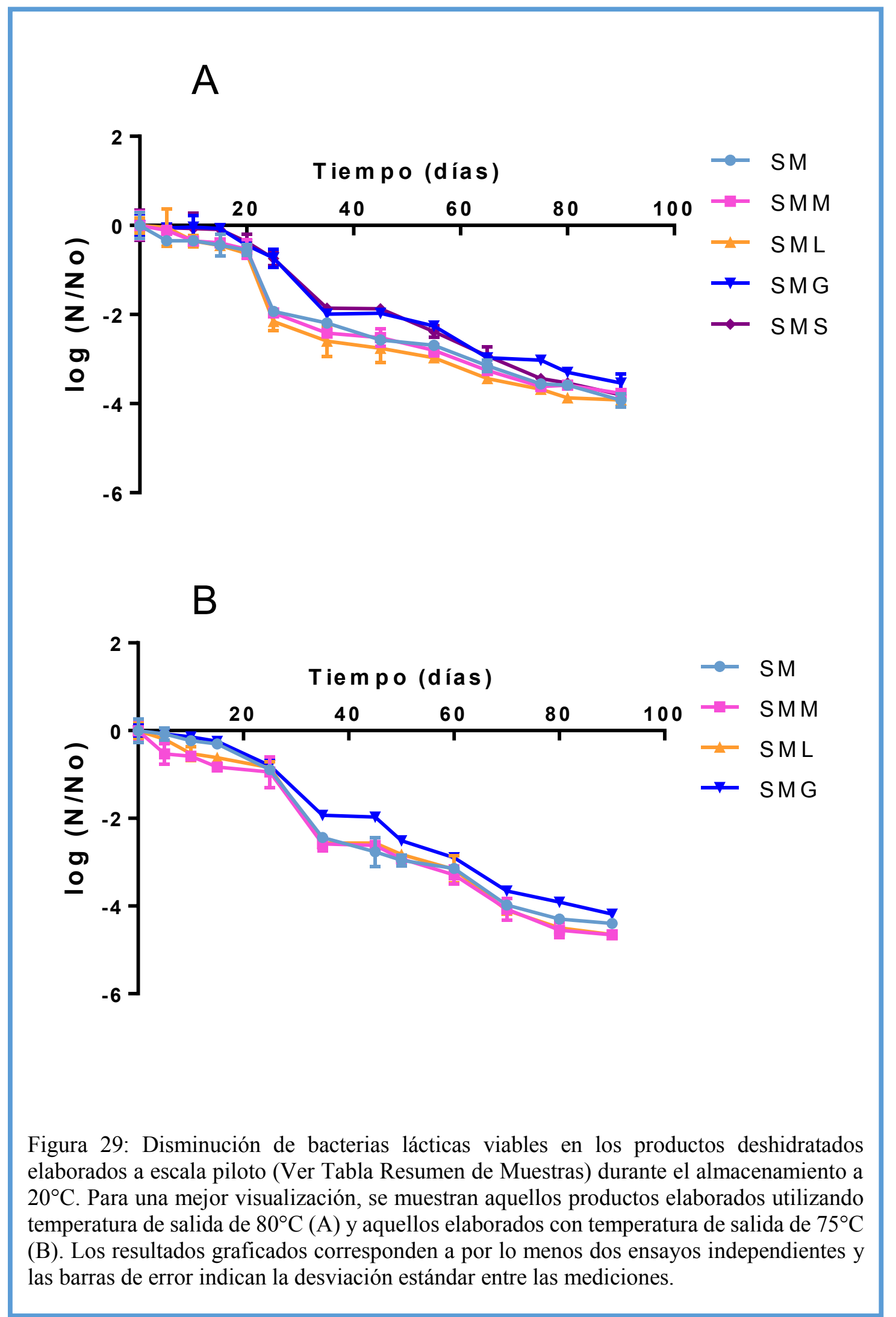


La actividad de agua de las muestras no sufrió modificaciones de importancia durante el almacenamiento para ninguna de las muestras, manteniéndose en valores similares a los iniciales (entre 0,25 y 0,3 ). Este comportamiento estable fue observado tanto para el almacenamiento a $4{ }^{\circ} \mathrm{C}$ (figura 30 ) como para el almacenamiento a $20{ }^{\circ} \mathrm{C}$ (figura 31 ), independientemente de la temperatura de salida con la que se obtuvo el producto. Este rango de valores asegura un producto que mantiene sus características ya que la región que comprende valores de aW entre 0,2 y 0,3 representa la región de contenido de humedad óptimo en la que los productos deshidratados tienen la máxima vida útil., como se comentó en la introducción 


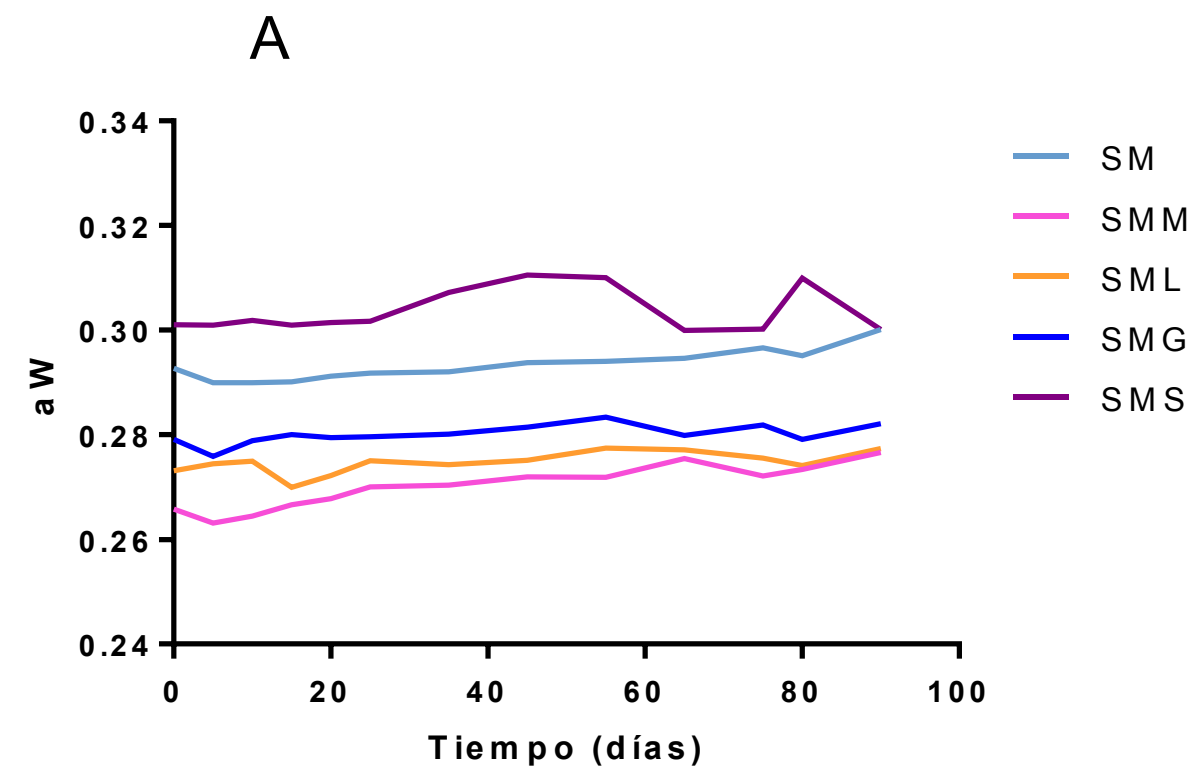

B

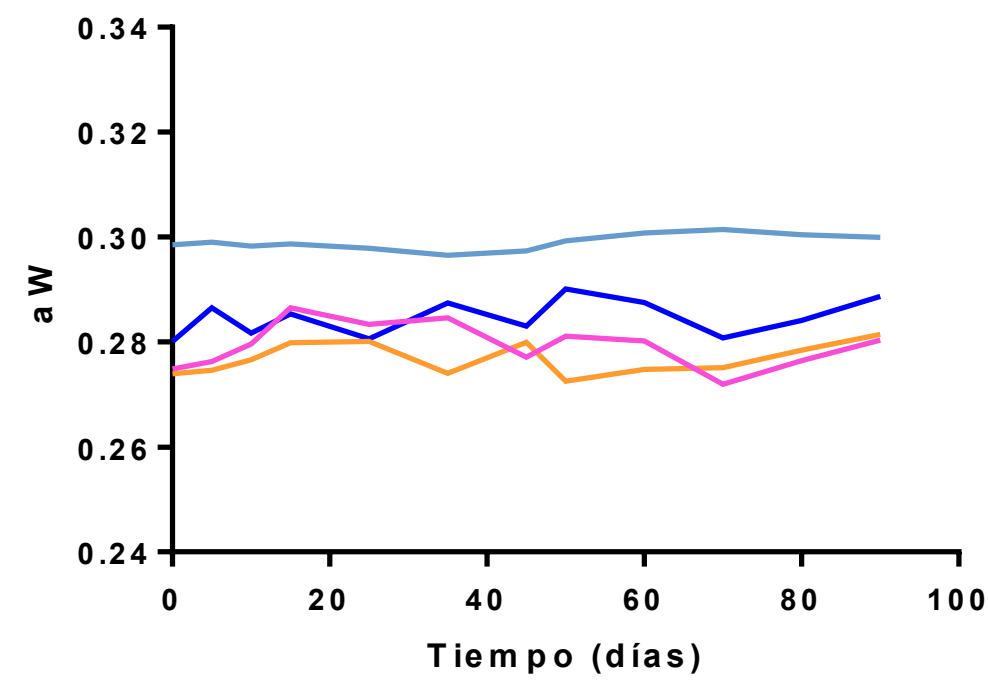

Figura 30: Actividad de agua de los productos elaborados a escala piloto (Ver Tabla Resumen de Muestras) durante el almacenamiento a $4^{\circ} \mathrm{C}$. En la figura A se muestran aquellos productos obtenidos con una temperatura de salida de $80^{\circ} \mathrm{C}$, mientras que en la figura B se muestran aquellos obtenidos con temperatura de salida de $75^{\circ} \mathrm{C}$. Los resultados graficados corresponden a por lo menos dos ensayos independientes. 


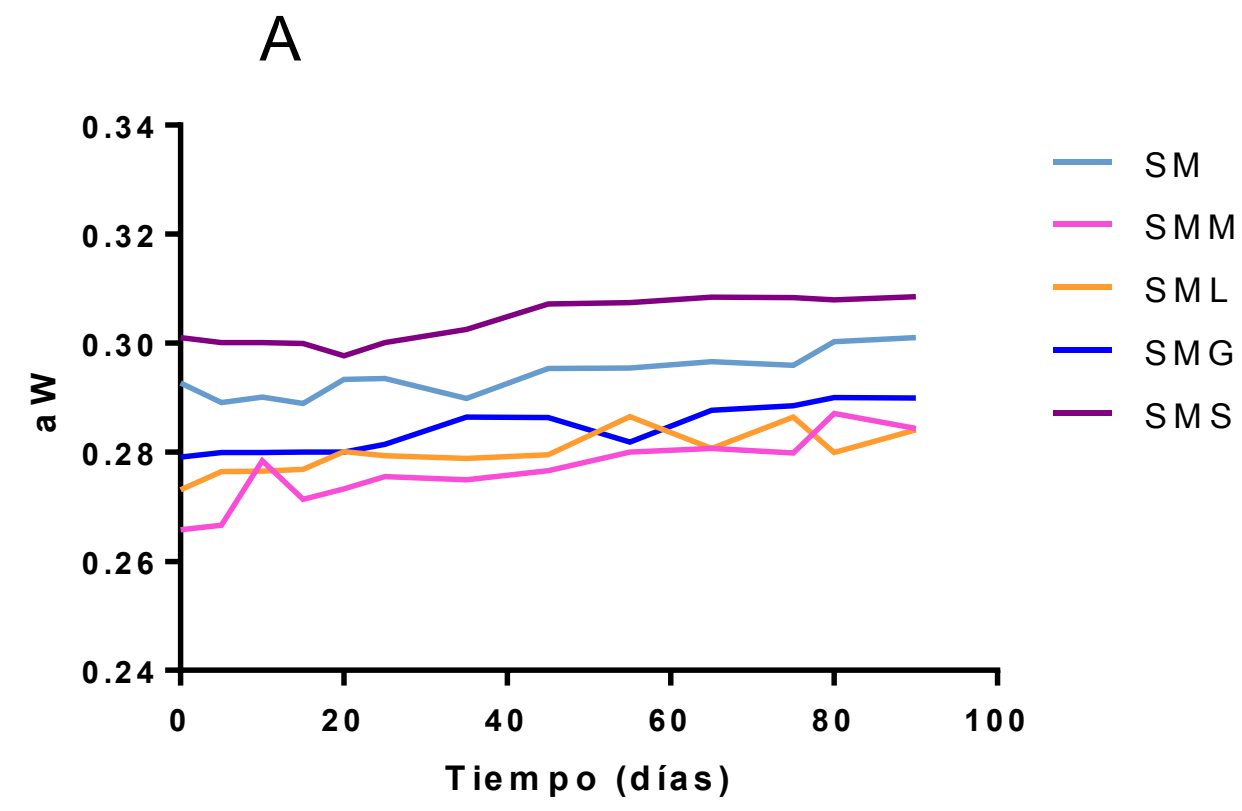

B

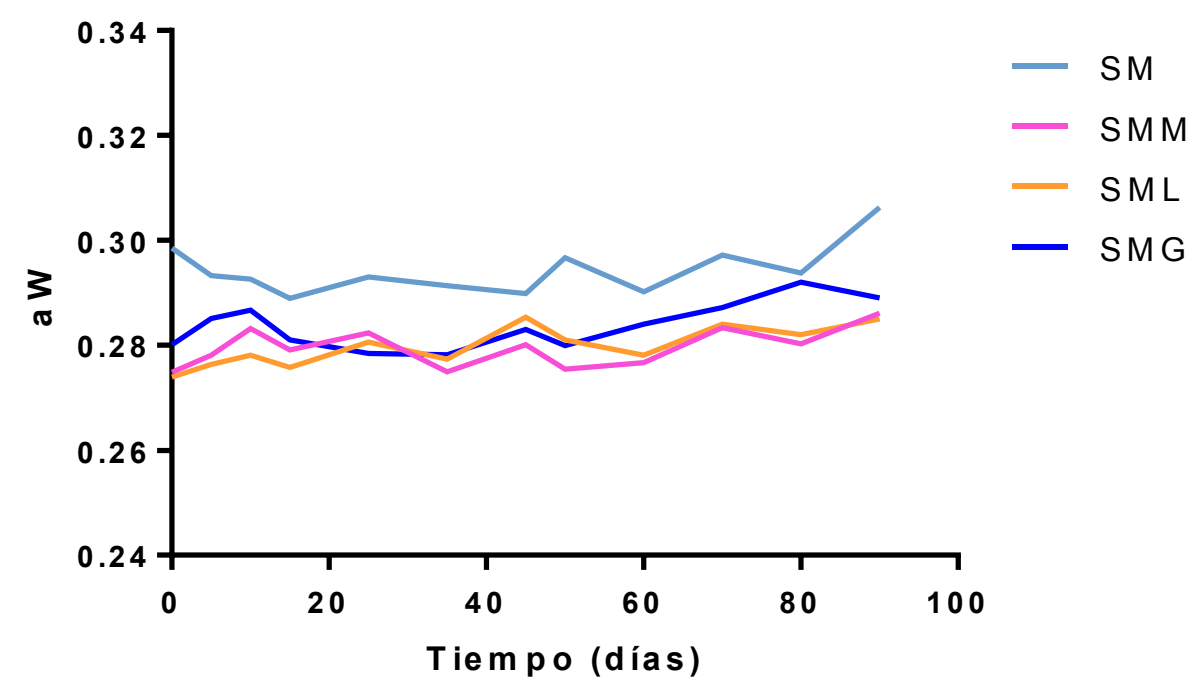

Figura 31: Actividad de agua de los productos elaborados a escala piloto (Ver Tabla Resumen de Muestras) durante el almacenamiento a $20^{\circ} \mathrm{C}$. En la figura A se muestran aquellos productos obtenidos con una temperatura de salida de $80^{\circ} \mathrm{C}$, mientras que en la figura B se muestran aquellos obtenidos con temperatura de salida de $75^{\circ} \mathrm{C}$. Los resultados graficados corresponden a por lo menos dos ensayos independientes. 
La mayor parte de la literatura disponible referente al secado spray se basa en ensayos y determinaciones realizadas a escala laboratorio. A escala piloto o industrial, existen muy pocos trabajos al respecto (Huang y col., 2017; Schuck y col., 2013), y al incrementar la escala comienzan a tener relevancia otros parámetros, como la mezcla y la homogeneidad de la alimentación, el bombeo y la atomización, que dificultan o hacen imposible la reproducción de resultados al pasar de escala laboratorio a escala piloto. Si bien es necesario profundizar en la optimización del proceso, en el presente trabajo se logró realizar el escalado con éxito, obteniendo un producto con características casi idénticas al obtenido a escala laboratorio y con un comportamiento similar durante el posterior almacenamiento. 


\subsection{CONCLUSIÓN}

En esta primera parte del trabajo de tesis fue posible establecer condiciones para deshidratar un producto elaborado a partir de kefir mediante secado spray. Este proceso pudo ser optimizado mediante el uso de diferentes carriers y escalado a planta piloto con éxito. El análisis multivariante permitió encontrar las relaciones entre las diferentes variables en estudio y las propiedades de los productos obtenidos. Estos productos obtenidos conservaron propiedades probióticas observadas en el kefir elaborado tradicionalmente las cuales fueron atribuidas a las bacterias lácticas viables presentes en ellos. Estas bacterias lácticas resistieron el pasaje por el tracto gastrointestinal y se pudo establecer que pertenecen principalmente a dos géneros asociados a microorganismos con potencialidad probiótica. Los estudios de almacenamiento mostraron que una correcta selección del carrier y de condiciones de almacenamiento permiten mantener la viabilidad bacteriana y la aW inalteradas hasta por lo menos 50 días a $4{ }^{\circ} \mathrm{C}$. 
SEGUNDA PARTE: ESTUDIOS DE LA CAPACIDAD PROBIÓTICA DE LOS PRODUCTOS

DESHIDRATADOS DESARROLLADOS FRENTE A

GIARDIA 


\subsection{INTRODUCCIÓN}

\subsubsection{Giardia}

Giardia intestinalis (sinónimos: Giardia lamblia o Giardia duodenalis) es un microorganismo eucariota unicelular flagelado, parásito de varios mamíferos, incluyendo el ser humano. Este parásito es considerado un patógeno zoonótico y la causa principal de diarrea causada por protozoarios a nivel mundial

\subsubsection{Ciclo de vida}

Todas las especies de este parásito poseen dos estados principales en su ciclo de vida: quiste y trofozoito. La infección comienza cuando un huésped ingiere quistes de Giardia, ya sea por beber agua o ingerir alimentos contaminados o por contacto directo fecal-oral (Figura 32, A y B). Los quistes son relativamente inertes, permitiendo una supervivencia prolongada incluso en condiciones ambientales adversas. Luego de la exposición al entorno ácido del estómago, estos desenquistan dando origen a trofozoitos en la porción proximal del intestino delgado (Figura. 32, C). El trofozoito (trofozoitos) es la forma vegetativa del parásito y se reproduce en el intestino delgado, colonizándolo y causando diarrea y malabsorción de nutrientes. Los trofozoitos se adhieren a los enterocitos a través de su disco ventral y se multiplican en el intestino (Figura 32, D y E). Al acercarse a porciones más distales del intestino, los trofozoitos encuentran un medio ambiente bajo en colesterol, alto en bilis y ligeramente alcalino que induce la aparición de una etapa de enquistamiento temprana, en la que los trofozoitos se redondean y las proteínas de enquistamiento específicas son transportadas por las vesículas a la superficie celular para formar el pared del quiste (Figura 32, F). El disco adhesivo se desmonta y la célula experimenta la replicación del ADN para dar una célula que contiene dos núcleos (4N cada uno). Durante la etapa de enquistación tardía, los núcleos se dividen, dando cuatro núcleos (2N cada uno), y el ADN se duplica nuevamente para generar un quiste maduro con cuatro núcleos y una ploidía total de $16 \mathrm{~N}$ 
(Ankarklev y col. 2010) (Figura 32, G). Los quistes se liberan en las heces, lo que permite completar el ciclo de transmisión infectando un nuevo hospedador (Figura 32, H).

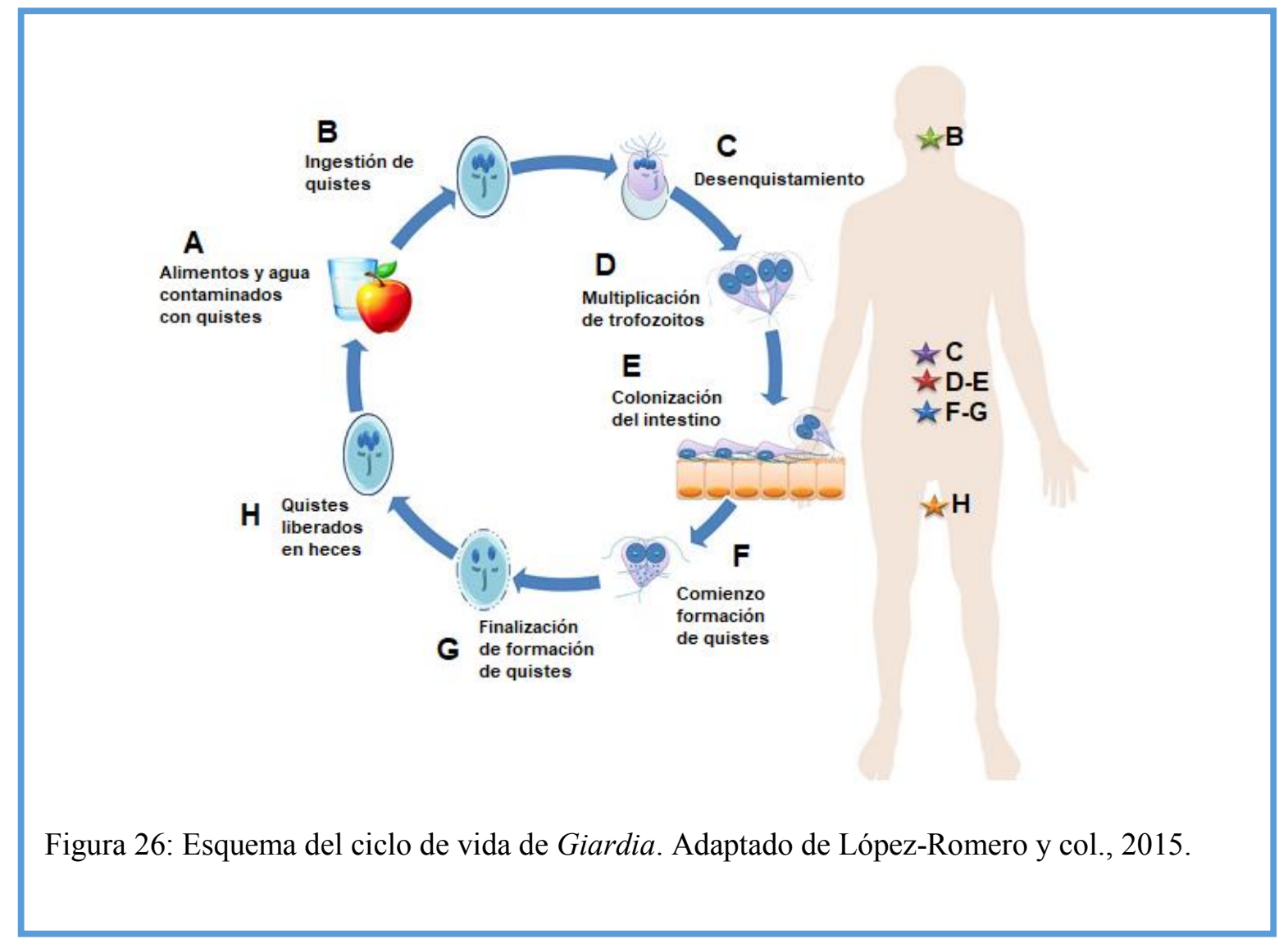

Como se explicó anteriormente, la infección en humanos se produce por la ingesta de quistes (aún en muy bajas dosis), ya sea directamente desde heces o indirectamente a través de aguas o alimentos. Se estima que en África, Asia y América Latina alrededor de 200 millones de personas sufren giardiasis sintomática, con 500000 nuevos casos cada año. En 2004, la giardiasis fue incluida dentro de la Neglected Disease intiative por la OMS. (Savioli y col. 2006)

La patogenia de Giardia no se comprende claramente y los síntomas que incluyen diarrea persistente, dolor abdominal y pérdida de peso rápida son muy variables (Thompson y col., 1993) y pueden no ser evidentes en una proporción significativa de individuos infectados (Rodriguez-Hernandez y col., 1996). Los factores de riesgo que predisponen a una infección con el parásito no se encuentran totalmente dilucidados, pero se cree que implican tanto 
factores ambientales y del hospedador, como el clon infectante. Aunque las especies de Giardia habitan en el tracto intestinal de prácticamente todas las clases de vertebrados, $G$. intestinalis es la única especie encontrada en humanos y la mayoría de los otros mamíferos, incluidos perros, gatos y ganado (Cacciò y col. 2017; Olson y col., 1995; Pavlaseck y col., 1995; Thompson, 1998).

\subsubsection{Patología}

Tal como se consignó anteriormente, los infectados con G. intestinalis desarrollan un diverso rango de manifestaciones clínicas que van desde la ausencia de síntomas hasta las diarreas crónicas con dolor abdominal agudo y náusea. Los síntomas diarreicos ocurren mayoritariamente durante la fase aguda de infección, y aunque la mayoría de las infecciones por Giardia son autolimitantes, pueden ocurrir reinfecciones o infecciones crónicas. Las investigaciones de las pasadas décadas establecieron que la fisiopatología de las giardiasis es un proceso multifactorial que involucra diversos factores; parásito, huésped, dieta, ambiente y procesos inmunológicos (Buret y col., 2015).

La fisiopatología de la diarrea aguda en Giardia implica un alto grado de apoptosis enterocítica, una disrupción de la función de barrera intestinal, la activación de linfocitos del huésped, el acortamiento de la vellosidades del ribete en cepillo mediado por linfocitos CD8+ (con o sin atrofia de vellosidades), deficiencias en la actividad disacaridasa, mala absorción en el intestino delgado, hipersecreción de aniones y aumento en la duración del tránsito intestinal. También se ha sugerido que existe una interferencia en el ciclo celular y la proliferación de los enterocitos, producido por el consumo de arginina por parte del parásito, que contribuye también a la patogénesis (Buret y col., 2007; Chin y col., 2002; Stadelmann y col., 2013; Troeger y col., 2007). 
La reducción de la función de barrera inducida por Giardia implica disrupciones del esqueleto de F-actina y las proteínas de la zonula occludens (ZO-1) tales como claudina-1 y claudina-4, ocludina y $\alpha$-actinina. Las disrupciones en las proteínas de unión estrecha por parte de Giardia son dependientes de caspasa-3, como en otros desórdenes intestinales; aunque la inhibición de las proteasas parasíticas no previene la degradación de las uniones estrechas intestinales, sugiriendo que la fisiopatología epitelial producida por Giardia es multifactorial (Chin y col., 2006; O'Hara y Buret, 2008; Panaro y col., 2007)

El acortamiento de microvellosidades inducido por Giardia causa una mala absorción de nutrientes en el intestino debido a un daño en la absorción de agua, glucosa y electrolitos. La hipersecreción de aniones puede contribuir entonces a que se genere diarrea. Nuevas investigaciones indican que Giardia puede causar una disminución de células caliciformes en tanto en el intestino delgado como en el colon (Amat, 2015).

Las interacciones microbio-microbio en el intestino podrían tener un rol clave en el desarrollo de giardiasis. Estudios previos han establecido que la microbiota comensal puede proteger al huésped de Giardia (Singer y Nash, 2000). Existen estudios que indican que Giardia puede inducir a una expansión en la cantidad relativa de Firmicutes y la aparición de grupos de proteobacteria en la microbiota intestinal humana (Beatty y col., 2013). Todas estas observaciones sugieren que Giardia podría generar un desbalance en favor de bacterias oportunistas de microbiota residente durante la fase aguda de infección. Así, esta microbiota alterada induce una respuesta inflamatoria en el huésped que sería la responsable, por lo menos en parte, de la complicaciones post infecciosas observadas en la giardiasis. Este tema está siendo muy investigado actualmente y podría conducir a nuevas terapias basadas en probióticos (Chen y col., 2013; Halliez y col., 2014). 


\subsubsection{Tratamiento}

Existen cuatro drogas que se usan comúnmente para tratar la giardiasis: metronidazol, tinidazol, furazolidona y quinacrina. Sin embargo, todas ellas presentan efectos adversos muchos de los cuales pueden ser peligrosos. Los nitroimidazoles (metronidazol y tinidazol) pueden causar náuseas, molestias gastrointestinales, erupciones cutáneas, somnolencia, y ocasionalmente leucopenia transitoria y neuropatía periférica. Se ha demostrado además que son cancerígenos en roedores y mutagénicos en bacterias. Más aún, no existe hoy en día un consenso general sobre el régimen de administración del mismo, el cual termina siendo una elección del médico de acuerdo a su preferencia y la disponibilidad de la droga.

La furazolidona, un 2 nitrofurano, es el fármaco de elección para el tratamiento de la giardiasis en niños pequeños. Sin embargo, puede ocurrir una amplia gama de efectos secundarios leves, que incluyen dolor de cabeza, náuseas, vómitos, erupciones cutáneas, diarrea y malestar general. La quinacrina se usa comúnmente en América del Norte. Este compuesto antipalúdico puede causar mareos, dolor de cabeza y trastornos gastrointestinales.

Además de los efectos adversos, los tratamientos actuales para la giardasis suelen mostrar una tasa elevada de fallas clínicas por diversas razones, entre las cuales se destacan: el incumplimiento del paciente con el régimen farmacológico prescrito, la posible reinfección del paciente (que es difícil de monitorear de un modo preciso y efectivo) y la falta de un criterio unificado para la evaluación de la cura (Gardner y Hill, 2001; Granados y col., 2012). 


\subsubsection{Giardiasis y probióticos}

Teniendo en cuenta la variabilidad en la efectividad y la gran cantidad de efectos adversos que presentan los tratamientos tradicionales para la infección con Giardia, se han buscado tratamientos alternativos para el control de la infección asociada a este parásito.

En el año 2000, Singer y Nash observaron experimentando con ratones una relación entre la susceptibilidad a la infección por Giardia y la microbiota intestinal (Singer y Nash, 2000), lo que podría sugerir que la infección por el parásito podría controlarse modificando el balance de las poblaciones microbianas intestinales, es decir, a través del uso de probióticos. En concordancia con estos hallazgos, Pérez y col. (2001) dieron un paso importante en este sentido al descubrir que el sobrenadante de la cepa probiótica LA1 de Lactobacillus johnsonii era capaz de controlar el crecimiento de Giardia in vitro. En dicho estudio también evaluaron otras cepas probióticas que no mostraron ningún efecto notable, lo que indica que el efecto es dependiente de la cepa probiótica utilizada. El sobrenadante de L. johnsonii LA1 bloqueó el desarrollo de G. intestinalis en la fase G1 del ciclo celular. Cuando este probiótico fue administrado en el agua de bebida de meriones, se observó una protección de los animales frente a la infección por Giardia, mostrando un menor daño de las estructuras de los enterocitos así como también menos alteraciones histológicas de la mucosa intestinal normalmente asociados con la giardiasis (Humen y col., 2005). Además, al quedar detenidos en la fase G1, los trofozoitos no pueden enquistar, ya que los quistes aparecen a partir de G2. Así, el efecto no sólo es importante al disminuir la intensidad de la infección (los síntomas y daños que ésta genera, y la cantidad de trofozoitos que se encuentran adheridos en el intestino), sino que también disminuye la capacidad de diseminación.

Otras cepas también demostraron ser eficaces contra el daño producido por la infección por Giardia. La administración de la cepa Lactobacillus casei MTCC 1423 a ratones disminuyó el número promedio de vellosidades atrofiadas y de células infiltrantes en el intestino 
delgado (Shukla y col., 2008). Por su parte, la administración de Enterococcus faecium SF68 generó una mejora de la respuesta inmune ya que se observó una producción de $\operatorname{IgA~e~IgG~}$ intestinal anti-Giardia específicas en ratones tratados (Benyacoub y col., 2005)

Si bien estos estudios convergen hacia la existencia de un efecto beneficioso proporcionado por diferentes tipos de probióticos en la giardiasis, es necesario continuar con las investigaciones para determinar los mecanismos puestos en juego.

Se han realizado observaciones que indicarían que los efectos de la giardiasis pueden deberse, en parte, a la disbiosis por microbiota inducida por el parásito durante la fase aguda de la infección (Buret y col. 2015). Estas nuevas observaciones, añaden una nueva relación entre la infección con Giardia y los probióticos, los cuales pueden tener un efecto en la manifestación clínica de la giardasis mediante una regulación de la microbiota.

\subsubsection{Modelos de investigación}

Se han utilizado tanto modelos animales como celulares para intentar comprender la infección de este parásito y su relación con el hospedador. Los ensayos in vitro utilizando modelos celulares suelen proponerse como una alternativa al ensayo animal debido a su menor costo y a que no genera las controversias éticas asociadas al uso de modelos animales. De todas formas, estos últimos otorgan un escenario más realista de lo que ocurre ante una infección con el patógeno.

\subsection{Modelos celulares}

Se han utilizado diferentes líneas celulares para modelar la interacción de Giardia con enterocitos: HeLa (Gupta, 1989), IEC6 (Rodríguez-Fuentes y col. 2006) e Int-407 (Ceu Sousa y col., 2001). Sin embargo, la línea celular Caco-2, es aquella que más ampliamente se ha empleado como modelo in vitro para la infección con Giardia (Perez y col. 2001; Humen et al, 2011; Fisher y col. 2013). Humen (2009) realizó una evaluación de diferentes 
modelos celulares: Caco-2, T84 y Caco-2-TC7 con distintas clones de la cepa H7 de Giardia intestinalis. Tomando este último estudio como referencia, se escogió el modelo de Caco-2TC7 como modelo celular para todos los experimentos realizados in vitro en el presente trabajo de tesis.

\subsection{Modelos animales}

Se han propuesto muchos modelos animales para describir tanto los mecanismos de infección del parásito como la respuesta del hospedador frente a su infección.

Para el caso particular de Giardia intestinalis, es decir, la especie capaz de infectar humanos, podemos mencionar modelos de G. intestinalis-ratón neonato (Hill, 1983); G. intestinalisratón adulto (Byrd y col., 1994) y G. intestinalis-merión (Araújo y col., 2008; Belosevic y col., 1983; Humen, 2009; Schaefer y col., 1991; Wallis y Wallis, 1986).

Establecer un modelo adecuado de infección es una de las claves para lograr una evaluación satisfactoria del efecto de los probióticos en la interacción parásito-hospedador. Para este trabajo se utilizó el modelo murino con ratones hembra C57BL/6, el cual fue considerado por Humen (2009) como uno de los más adecuados para realizar estudios de infección por Giardia intestinalis y evaluar la respuesta del hospedador en el curso de la infección. 


\subsection{OBJETIVOS}

Teniendo en cuenta lo expuesto, para la presente parte del trabajo de tesis se plantearon los siguientes objetivos específicos:

- Estudiar los efectos de productos frescos y deshidratados elaborados sobre la proliferación del parásito y su adhesión a células Caco-2-TC7 in vitro.

- Evaluar los efectos de los productos frescos o deshidratados sobre la distribución y localización de proteínas de unión estrecha intercelular.

- Estudiar los efectos de la administración de un producto probiótico deshidratado sobre la intensidad de infección por parte Giardia in vivo, tanto a nivel de trofozoitos adheridos al intestino como a nivel de daño microscópico.

- Examinar los efectos sobre la inmunidad causados por la administración del producto deshidratado en presencia o ausencia de infección por parte de Giardia.

- Estudiar los efectos tanto del producto probiótico como del parásito sobre las poblaciones celulares de médula ósea y las subpoblaciones bacterianas en la microbiota intestinal. 


\subsection{MATERIALES Y MÉTODOS}

\subsubsection{Cultivos}

\subsubsection{Cultivos de Giardia intestinalis}

Para todos los experimentos se utilizó la cepa H7 (ATCC 50581) de Giardia intestinalis proveniente del American Type Culture Collection (ATCC, Rockville, USA).

Los parásitos se cultivaron en tubos de vidrio conteniendo $12 \mathrm{ml}$ de medio TYI. Los subcultivos se realizaron descartando el sobrenadante conteniendo los trofozoitos no adheridos, adicionando $2 \mathrm{ml}$ por tubo de medio TYI e incubando 10 minutos sobre hielo para despegar los trofozoitos adheridos. Posteriormente se inocularon $0,2 \mathrm{ml}$ de la suspensión resultante en medio TYI y se incubó por 48 a 72 horas a $37^{\circ} \mathrm{C}$ en oscuridad.

\subsubsection{Cultivo de kefir en diferentes medios}

Para los desafíos contra el parásito se utilizaron sobrenadantes y fracciones bacterianas provenientes de la fermentación de diferentes medios con gránulos de kefir. Los medios utilizados fueron leche UHT, permeado de suero al $20 \%$ y medio MTYI. Para todos los casos se realizó una inoculación al $10 \%$ (p/v) con gránulos de kefir AGK1 y se incubó a 20 ${ }^{\circ} \mathrm{C}$ durante 24 horas, tal como se describe en la primera parte del presente trabajo de tesis (Seccion 1.3.1).

Para la obtención de sobrenadantes, el producto obtenido tras la fermentación fue centrifugado a $10000 \mathrm{x}$ g durante 15 minutos a $4{ }^{\circ} \mathrm{C}$. En caso que fuese indicado el $\mathrm{pH}$ del sobrenadante fue ajustado utilizando $\mathrm{NaOH} 5 \mathrm{M}$.

Los pellets obtenidos fueron suspendidos en PBS para los ensayos de proliferación y en MTYI para los ensayos de adhesión. En caso de ser necesario, fueron conservados a $-20{ }^{\circ} \mathrm{C}$ hasta su uso. 


\subsubsection{Cultivo de Lactobacillus plantarum CIDCA 83114.}

Se realizaron también desafíos con sobrenadantes y fracciones bacterianas de L. plantarum CIDCA 83114, una cepa aislada de kefir, crecido en MRS, MTYI o permeado de suero al $20 \%$ a $37^{\circ} \mathrm{C}$ durante 12 horas.

Para la obtención de sobrenadantes, el cultivo obtenido una vez transcurrida la incubación fue centrifugado a $10000 \mathrm{x}$ g durante 15 minutos a $4{ }^{\circ} \mathrm{C}$. En el caso que fuese indicado el $\mathrm{pH}$ del sobrenadante fue ajustado utilizando $\mathrm{NaOH} 5 \mathrm{M}$.

Los pellets obtenidos fueron suspendidos en PBS y conservados a -20 para su posterior uso

\subsubsection{Cultivo de enterocitos humanos}

Los enterocitos humanos de la línea, Caco-2 clon TC7 (Caco-2-TC7) fueron cultivados en medio DMEM (Dulbecco's modified Eagle's minimum essential medium). Las monocapas celulares se prepararon en placas de cultivo celular (Greiner Bio One, Alemania) de 24 fosas, con un inóculo inicial de $1,4 \times 10^{5}$ células por $\mathrm{ml}(0,5 \mathrm{ml}$ por fosa). Los ensayos y el mantenimiento celular fueron llevados a cabo a $37{ }^{\circ} \mathrm{C}$ en una atmósfera de $10 \%$ de $\mathrm{CO}_{2}$.

Las células fueron utilizadas tras 7 días de cultivo, momento en que se encuentran totalmente diferenciadas y en confluencia. Para los ensayos que requirieron observación por técnicas de microscopia, las células fueros crecidas sobre cubreobjetos de $12 \mathrm{~mm}$ de diámetro (Assistent, Sondheim, Alemania) en las mismas condiciones. 


\subsubsection{Estudios in vitro}

\subsubsection{Ensayo de proliferación de Giardia}

Los cultivos de Giardia se cosecharon y se suspendieron en TYI-S-33 en una concentración conocida. Para esto, a partir de un cultivo confluente de Giardia H7, se descartó el medio de cultivo con los trofozoitos no adheridos a la superficie para luego despegar los trofozoitos adheridos utilizando $2 \mathrm{ml}$ de TYI-S-33 e incubando en hielo por 10 minutos. La suspensión de trofozoitos obtenida fue centrifugada a $1000 \mathrm{x}$ g durante 10 minutos, para luego suspender en $1 \mathrm{ml}$ de TYI-S-33 a temperatura ambiente. Mediante recuento en cámara de Neubauer y dilución en TYI-S-33, se ajustó la concentración final de trofozoitos, que en este caso fue de $1,25 \times 10^{5}$ trofozoitos $/ \mathrm{ml}$.

Luego se realizó el desafió contra los diferentes sobrenadantes o fracciones microbianas en placa de 24 fosas (volumen final: 2,4 ml) del siguiente modo:

En todas las fosas se colocaron $800 \mu$ suspensión de trofozoitos en TYI-S-33 $\left(1 \times 10^{5}\right.$ trofozoitos aprox.), $800 \mu \mathrm{l}$ de TYI-S-33 y $800 \mu \mathrm{l}$ del sobrenadante o fracción microbiana a evaluar. En el caso de los controles, estos últimos $800 \mu$ fueron reemplazados por medio TYI-S-33.

La placa se incubó a $37^{\circ} \mathrm{C}$ en anaerobiosis durante 48 hs. Transcurrido dicho se tiempo, se contaron los trofozoitos de cada fosa utilizando cámara de Neubauer.

\subsubsection{Ensayo de adhesión a enterocitos (Caco-2-TC7)}

Los ensayos de adhesión fueron llevados a cabo como fuera previamente descripto (Ceu Sousa y col., 2001) y adaptado con éxito por Humen (2009) para el modelo celular utilizado.

Los trofozoitos de Giardia se cosecharon y se suspendieron en DMEM adhesión en una concentración conocida. Para los ensayos de adhesión a células, se usaron dos 
concentraciones de Giardia: 1 x $10^{6}$ y 2 × $10^{6}$ trofozoitos/ml., que corresponden a una MDI de 1 y 2 respectivamente.

Para lograr esto a partir de un cultivo confluente de Giardia, primero se descartó el medio de cultivo con los trofozoitos no adheridos a la superficie. Acto seguido se despegaron los trofozoitos adheridos con PBS $(\mathrm{pH}=7.2)$ en frío por 10 minutos. Se centrifugó a 1000 x g durante 10 minutos, se descartó el sobrenadante y se lavó nuevamente el pellet con PBS frío y se repitió la centrifugación. El pellet obtenido se suspendió en DMEM de adhesión. Se contó en cámara de Neubauer y se ajustó la concentración final de trofozoitos mediante dilución en DMEM de adhesión.

Para evaluar el efecto de los sobrenadantes, los trofozoitos fueron preincubados tanto con los sobrenadantes (neutralizados y filtrados) como con las fracciones microbianas de los productos frescos o deshidratados por secado spray antes de realizar la infección de los enterocitos. Dicha preincubación se realizó durante $1 \mathrm{~h}$ a $37{ }^{\circ} \mathrm{C}$ en dos proporciones de sobrenadante o pellet resuspendido, $1: 3$ y $1: 1$.

Las monocapas celulares fueron lavadas con DMEM de adhesión para retirar células no adheridas y partículas en suspensión. Los trofozoitos preincubados en las diferentes condiciones fueron llevados a una concentración de $2 \times 10^{6}$ y 4 × $10^{6}$ trofozoitos $/ \mathrm{ml}$ en DMEM de adhesión para evaluar dos multiplicidades de infección (número de trofozoitos de Giardia por célula) MDI=1 y MDI=2 respectivamente. Finalmente los trofozoitos fueron co-incubados con las células Caco-2-TC7 a $37^{\circ} \mathrm{C}$ en un volumen final de $0,5 \mathrm{ml}$ por fosa durante 3 h. Luego de la co-incubación los trofozoitos fueron recuperados con $2 \mathrm{ml}$ de DMEM de adhesión frío sobre hielo y posteriormente contados en cámara de Neubauer. 


\subsubsection{Evaluación del efecto sobre las proteinas de unión intercelular}

Las monocapas de enterocitos confluentes y diferenciadas crecidas sobre cubreobjetos de vidrio de $12 \mathrm{~mm}$ de diámetro fueron lavadas dos veces con buffer PBS previo a la infección. Posteriormente, las células fueron infectadas apicalmente con 2 × $10^{6}$ trofozoitos de Giardia intestinalis cepa $\mathrm{H} 7$ suspendidos en 0,5 $\mathrm{ml}$ de DMEM de adhesión (como fuera previamente descripto en el ensayo de adhesión) con una $\mathrm{MDI}=2$.

También se evaluó el efecto del sobrenadante de kefir fresco neutralizado y una combinación de trofozoitos de Giardia y sobrenadante de kefir fresco neutralizado (manteniendo siempre la MDI=2). Para los controles no infectados se utilizó DMEM de adhesión en igual volumen. Las placas fueron incubadas a $37{ }^{\circ} \mathrm{C}$ con atmósfera al $10 \%$ de $\mathrm{CO}_{2}$ por $24 \mathrm{~h}$, previo a su procesamiento por inmunofluorescencia

\subsection{Inmunofluorescencia}

La marcación fue llevada a cabo como fuera previamente descripto (Lievin-Le Moal y col., 2002): luego de la infección las células fueron lavadas tres veces con PBS y fijadas por 15 minutos con paraformaldheído $3 \%$ en PBS. Una vez finalizada la fijación, se realizaron tres lavados con PBS y las células se trataron con $\mathrm{NH} 4 \mathrm{Cl} 50 \mathrm{mM}$ por 10 min para saturar las funciones aldehído libres.

Se realizó una marcación por inmunofluorescencia indirecta para detectar la ubicación de las proteínas ocludina y claudina-1, las cuales están presentes en las uniones intercelulares.

Para ello las células fijadas fueron incubadas con el anticuerpo primario diluido en PBSgelatina $0,2 \%$ durante $45 \mathrm{~min}$. Las diluciones de los anticuerpos fueron 1/50 para anticlaudina-1 y 1/100 para anti-ocludina (ThermoFisher, EEUU).

Una vez finalizada la incubación, las células se lavaron 3 veces con buffer PBS ( $\mathrm{pH}=7.2)$, para luego ser incubadas durante 45 min con el anticuerpo secundario conjugado con FITC 
diluido1/200 en PBS-gelatina 0,2 \%. Posteriormente, las células fueron lavadas 3 veces con PBS y fueron montadas con medio de montaje para inmunofluorescencia (DakoCytomation fluorescent mounting médium, Agilent, EEUU). Las imágenes fueron obtenidas con un microscopio láser confocal (Zeiss LSM510, Zeiss, Alemania) equipado con un láser de ion argón de $488 \mathrm{~nm}$ enfriado por aire, y un láser helio-neón de $543 \mathrm{~nm}$, acoplado a un microscopio Axiovert 100M usando un objetivo de inmersión Plan Apochromat 63X/1.40.

\subsubsection{Estudios in vivo}

\subsubsection{Modelo utilizado.}

Para los ensayos in vivo se utilizaron hembras de ratón C57BL/6 SPF (libres de patógenos específicos) de 6-7 semanas de edad, provistos por el bioterio de la Facultad de Ciencias Veterinarias de la UNLP. Los animales fueron trasladados al bioterio de la Cátedra de Microbiología de la Facultad de Ciencias Exactas de la UNLP 7 días antes de comenzar el tratamiento con el objeto de que los animales se adapten al nuevo entorno y disminuir los efectos causados por el estrés del traslado y la separación en grupos

Los animales se mantuvieron siempre en un sistema de barreras controlado para evitar cualquier tipo de contaminación (ya sea externa o cruzada). Los procedimientos realizados fueron realizados bajo normas internacionales de trabajo con animales de experimentación y aprobados por la CICUAL (Protocolo número: 003-23-16).

La utilización de ratones C57BL/6 como modelo murino de la infección de Giardia ha sido previamente validado por nuestro grupo de investigación (Humen, 2009). Este modelo ha demostrado ser apropiado para evaluar tanto el curso de la infección como el efecto causado por la administración de probióticos. 


\subsubsection{Administración del probiotico}

Comúnmente la administración de productos probióticos (o microorganismos probióticos) en los ensayos in vivo se realizan a partir de un cultivo fresco concentrado, que se conserva congelado, generalmente a $-80{ }^{\circ} \mathrm{C}$. La administración de un probiótico deshidratado, constituye una aproximación experimental poco utilizada a pesar de resultar más acorde en el contexto de la posible aplicación de los resultados obtenidos. Debe tenerse en cuenta que la conservación de un producto deshidratado puede llevarse a cabo a $4{ }^{\circ} \mathrm{C}$ con adecuado mantenimiento de la viabilidad de los microorganismos. Por otro lado, esta presentación del producto presenta ventajas para el transporte, la manipulación y el almacenamiento.

Teniendo en cuenta los resultados obtenidos en el estudio del método de secado spray en la sección anterior, se escogió una cepa aislada de kefir (L. plantarum CIDCA 83114) para formular un producto probiótico deshidratado. La bacteria fue crecida en permeado de suero al $20 \%(\mathrm{p} / \mathrm{v})$ para realizar una evaluación del uso de un medio de cultivo y deshidratación de bajo costo. Esta cepa crecida durante $24 \mathrm{~h}$ a $37^{\circ} \mathrm{C}$ en permeado de suero $20 \%$ (p/v) fue deshidratada directamente (ver sección 1.3.2.1.3) utilizando el mismo equipamiento y las mismas condiciones de operación que se utilizaron en la primera parte de este trabajo de tesis para el secado escala laboratorio: Temperatura de entrada: $135^{\circ} \mathrm{C}$ y feed: $30 \%$, lo que resultó en una temperatura de salida de $67^{\circ} \mathrm{C}$.

El producto deshidratado fue administrado ad libitum suspendido $1 / 10 \mathrm{p} / \mathrm{v}$ en el agua de bebida. Los grupos de animales que no recibieron el probiótico, recibieron en cambio permeado de suero (producto control) deshidratado en las mismas condiciones que el producto y suspendido en el agua de bebida en la misma proporción.

\subsubsection{Grupos experimentales}

Los grupos utilizados en el ensayo fueron los siguientes: 
- C (Control): Los animales de este grupo recibieron el producto control suspendido su agua de bebida (1/100 p/v) Se les administró PBS por sondaje orogástrico.

- P (Probiótico): Los animales de este grupo recibieron el producto probiótico a base de L. plantarum CIDCA 83114 deshidratado en su agua de bebida (1/100 $\mathrm{p} / \mathrm{v})$. Se les administró PBS por sondaje orogástrico.

- G (Giardia): Los animales de este grupo recibieron el producto control suspendido en su agua de bebida $(1 / 100$ p/v). Se les administró una suspensión de trofozoitos de Giardia intestinalis cepa H7 en PBS por sondaje orogástrico.

- PG (Probiótico+Giardia): Los animales de este grupo recibieron el producto probiótico a base de L. plantarum CIDCA 83114 deshidratado en su agua de bebida $(1 / 100$ p/v). Se les administró una suspensión de trofozoitos de Giardia intestinalis cepa H7 en PBS por sondaje orogástrico.

La administración del probiótico (o del producto control) comenzó una semana antes de la infección con el parásito. Los grupos experimentales y los tratamientos recibidos se resumen en la Tabla 18.

Tabla 18: Resumen de los grupos y los respectivos tratamientos para el ensayo in-vivo. . C: grupo control sin tratamiento; P: grupo que consumió sólo la cepa probiótica; G: Grupo infectado con Giardia intestinalis cepa H7. PG: Grupo tratado con la cepa probiótica e infectado con Giardia intestinalis cepa H7.

\begin{tabular}{|c|c|c|c|}
\hline Grupo & Probiótico & Giardia & Producto Control \\
\hline C & - & - & + \\
\hline P & + & - & - \\
\hline PG & + & + & - \\
\hline G & - & + & + \\
\hline
\end{tabular}




\subsubsection{Protocolo de infección}

La inoculación de los animales se llevó a cabo por sondaje orogástrico con $200 \mu \mathrm{l}$ de una suspensión conteniendo $5 \times 10^{8}$ trofozoitos $/ \mathrm{ml}$ en PBS, lo cual representa aproximadamente $1 \times 10^{7}$ trofozoitos por animal. Los grupos de animales que no fueron infectados con el parásito recibieron un volumen igual de PBS también por sondaje orogástrico, como se explicó anteriormente.

El inóculo de $1 \times 10^{7}$ trofozoitos por animal fue establecido como la dosis infectiva en el modelo murino durante su puesta a punto (Humen, 2009).

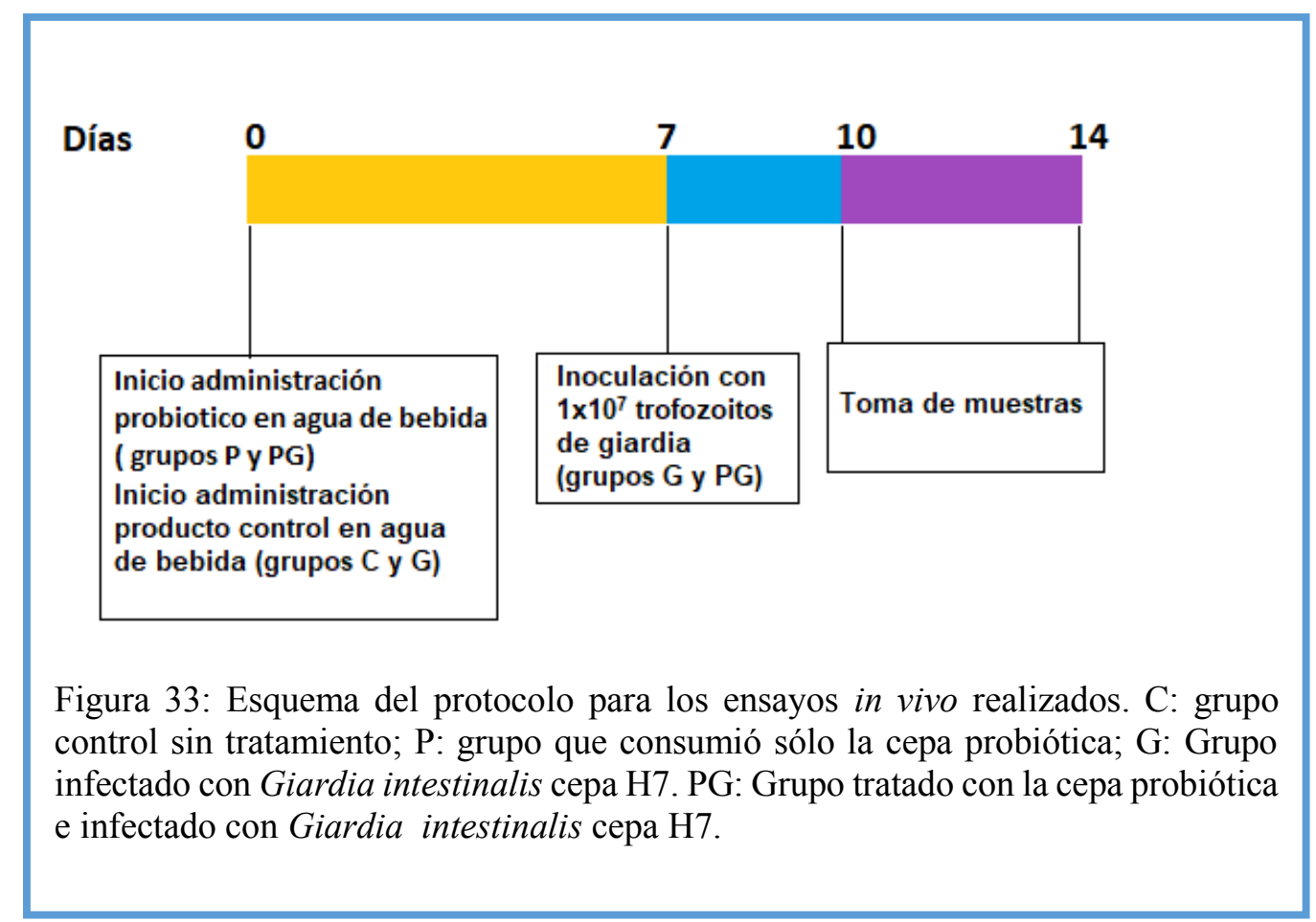

Como se muestra en el esquema de la figura 33, a distintos tiempos pos-infección ( 3 y 7 días), los animales fueron sacrificados por inhalación de $\mathrm{CO}_{2}$ y se extrajeron las muestras a analizar. 


\subsubsection{Recuento de trofozoitos en intestino delgado}

Para evaluar la concentración duodenal de trofozoitos, se tomaron porciones de $5 \mathrm{~cm}$ de intestino delgado entre 5 y $10 \mathrm{~cm}$ a partir del píloro y se colocaron en $1 \mathrm{ml}$ de medio TYI-S33 frío. Se realizaron dos lavados con el mismo medio para arrastrar los trofozoitos adheridos a la pared intestinal y, a continuación, se cortó longitudinalmente la porción de intestino y se homogeneizó en vortex. Los trofozoitos fueron contados en una cámara de Neubauer.

\subsubsection{Preparados histológicos}

Para el análisis histológico se colectaron porciones de $1 \mathrm{~cm}$ de intestino (tomados $5 \mathrm{~cm}$ distales del píloro), que fueron fijadas directamente en etanol $96 \%$ y posteriormente deshidratadas en etanol absoluto previo a su inclusión en parafina. Las secciones embebidas en parafina fueron cortadas en micrótomo con un espesor de $5 \mu \mathrm{m}$, rehidratadas y coloreadas con hematoxilina-eosina.

\subsubsection{Estudio de poblaciones celulares en médula ósea}

\subsection{Preparación celular}

Las células de la médula ósea se obtuvieron lavando fémures de ratones con DMEM de adhesión. El número de células viables en médula ósea de determino utilizando Azul de Tripán y empleando una cámara de recuento de Neubauer.

\subsection{Citometría de flujo}

Tanto las marcaciones de las células como el análisis de los datos obtenidos fueron llevados a cabo como fuera previamente descripto por Salva y col. (2014). Las suspensiones de células de médula ósea fueron lavadas dos veces en tampón FACS helado (solución fisiológica, suero bovino fetal al $2 \%$, Gibco) y fueron incubadas previamente con anticuerpo 
monoclonal anti-ratón CD32 / CD16 (bloqueo Fc) durante 30 minutos a $4{ }^{\circ} \mathrm{C}$. Posteriormente, las células fueron incubadas en las mezclas de anticuerpos durante 30 minutos a $4{ }^{\circ} \mathrm{C}$ y lavadas con buffer FACS. Los anticuerpos utilizados y su marcación se resumen en la Tabla 19. Todos los anticuerpos fueron adquiridos a BD Pharmingen (BD Biosciences, EEUU). Se realizaron dos marcaciones en paralelo: una para identificar las distintas subpoblaciones presentes en la médula ósea (CD34/CD117/ Ly6A/E / Lin-APC) y otra para identificar las subpoblaciones mayoritarias del linaje mieloide maduro, es decir neutrófilos, monocitos y eosinófilos (Gr-1/Ly6G/Ly6C). En todos los casos, las células fueron adquiridas en un citómetro de flujo FACSCalibur (BD Biosciences, EEUU) y los datos fueron analizados con el software FlowJo (TreeStar, EEUU).

Tabla 19: Resumen de los diferentes anticuerpos empleados para las marcaciones para el análisis de células de médula ósea por citometría de flujo.

\begin{tabular}{|c|c|c|}
\hline $\begin{array}{l}\text { Anticuerpo } \\
\text { anti- }\end{array}$ & $\begin{array}{l}\text { Conjugado } \\
\text { con }\end{array}$ & Permite detectar \\
\hline CD34 & FITC & Células madre hematopoyéticas \\
\hline $\begin{array}{l}\text { CD117 (c- } \\
\text { kit) }\end{array}$ & $\mathrm{PE}$ & $\begin{array}{l}\text { Células pluripotenciales comprometidas en linaje } \\
\text { mieloide }\end{array}$ \\
\hline Gr-1 & $\mathrm{PE}$ & Células granulocíticas maduras \\
\hline Lin & APC & Células linaje mieloide maduras \\
\hline $\begin{array}{l}\text { Ly6A/E } \\
\text { (SCa-1) }\end{array}$ & Biot-St & Células linaje linfoide maduras \\
\hline Ly6C & Biot-St & Monocitos \\
\hline Ly6G & FITC & Neutrófilos \\
\hline
\end{tabular}

FITC: Isotiocianato de fluoresceína; PE: ficoeritrina; APC: aloficocianina; Biot-St: Biotina/estreptavidina marcada

\subsubsection{Expresión de citoquinas en placas de Peyer}

Las muestras de placas de Peyer extraídas de los animales sacrificados fueron colocadas en $500 \mu \mathrm{l}$ de RNAlater (Invitrogen, ThermoFisher, EEUU), un reactivo que impregna 
rápidamente los tejidos para estabilizar y proteger el $\mathrm{ARN}$, minimizando la necesidad de procesar inmediatamente muestras de tejido. Las muestras sumergidas en RNA later fueron conservadas a $-80{ }^{\circ} \mathrm{C}$ hasta su procesamiento.

\subsection{Extracción de ARN total de placas de Peyer}

Para la extracción de ARN, las placas de Peyer fueron retiradas del RNAlater y colocadas en buffer de lisis, donde fueron procesados utilizando un homogeneizador de alta velocidad Ultraturrax (IKA, China).

Para la obtención de ARN total del homogenato de MLN, se utilizó el protocolo comercial Mini RNA Isolation Kit (GE Healthcare, Reino Unido).

El lisado celular se transfirió a un tubo plástico de 1,5 ml, se agregaron $350 \mu 1$ de etanol 70 $\% \mathrm{v} / \mathrm{v}$ y la mezcla se dispuso en una columna de extracción de ARN para microcentrifuga con un tubo colector. Se centrifugó a 10000 x g durante 30 seg. El contenido del tubo colector se descartó. Se agregaron sobre la columna $350 \mu \mathrm{l}$ de buffer de desalinización y se centrifugó a $11000 \mathrm{x}$ g durante $1 \mathrm{~min}$. El ADN en la muestra que puede interferir en las reacciones posteriores, se eliminó agregando $95 \mu 1$ de DNAsa mix (10 $\mu$ de DNAsa reconstituida en 90 $\mu \mathrm{l}$ de buffer de reacción para DNAsa), la reacción se llevó a cabo a temperatura ambiente durante 15 min. Luego se inactivó la DNAsa colocando $200 \mu 1$ de buffer RA2 sobre la columna y se centrifugó 1 min a 8000 x g. Se lavó la columna 2 veces con $600 \mu 1$ y $250 \mu 1$ de buffer RA3 y se centrifugó a 11000 x g por 1 min y 2 min respectivamente para que la columna se secara completamente. Finalmente la columna se colocó en un tubo de 1,5 ml y se eluyó el ARN agregando $100 \mu 1$ de agua libre de RNAsa y centrifugando a 11000 x g por 2 min. En estos protocolos fue indispensable el uso de material libre de RNAsa, DNAsa y pirógenos, así como también puntas de pipetas automáticas con filtro para obtener productos de calidad y evitar pérdidas de material. 


\subsection{Transcripción reversa}

La transcripción reversa (Reverse transcription-PCR, RT-PCR) permite sintetizar ADN complementario (ADNc) a partir de moléculas de ARN haciendo uso de la enzima transcriptasa reversa. El ADNc obtenido es la cadena complementaria de la cadena molde de ARN. Esta técnica se utiliza en combinación con PCR cuantitativa para la cuantificación de la expresión génica.

La transcripción reversa hace uso de random primers, que son hexámeros de nucleótidos en todas sus combinaciones posibles, es decir $4^{6}=4096$ posibles combinaciones de bases, lo que le da la capacidad de unirse (y por lo tanto amplificar) cualquier sección del ARN presente en la muestra.

Se preparó entonces una premezcla con $13 \mu \mathrm{l}$ random primers $(50 \mu \mathrm{M})$ con $91 \mu \mathrm{H} 2 \mathrm{O}$. Luego se prepararon tubos con $1 \mu \mathrm{l}$ de esta premezcla y $11 \mu \mathrm{l}$ de muestra (aproximadamente $1 \mu \mathrm{g}$ de ARN extraído) y se colocaron a $70{ }^{\circ} \mathrm{C}$ por 10 min en un bloque térmico. A continuación, se enfriaron inmediatamente en hielo y se agregaron a cada tubo de reacción $1 \mu \mathrm{l}$ de inhibidor de RNAsa, $1 \mu \mathrm{l}$ de ditiotreitol, $4 \mu \mathrm{l}$ de buffer de reacción 5X (Invitrogen), $1 \mu \mathrm{l}$ de solución $10 \mathrm{mM}$ de dNTPs y $1 \mu \mathrm{l}$ de MMLV-Reverse Trascriptase (Invitrogen), obteniéndose un volumen final de $20 \mu \mathrm{l}$ por tubo.

La reacción se llevó a cabo en un termociclador con el siguiente programa: paso 1) $25{ }^{\circ} \mathrm{C}$, 10 min; paso 2) $42{ }^{\circ} \mathrm{C}, 2$ horas. El ADNc obtenido se conservó a $-20{ }^{\circ} \mathrm{C}$

\subsection{PCR cuantitativa en tiempo real}

Para cuantificar la expresión génica de las diferentes citoquinas analizadas se realizó una PCR cuantitativa en tiempo real (qPCR). Esta técnica se realiza en un termociclador que puede emitir un haz de luz de una determinada longitud de onda y detectar luego la fluorescencia emitida por el fluorocromo excitado. En este caso, se utilizó Sybr Green un 
fluorocromo intercalante que se incorpora al ADN bicatenario y que es excitado mediante luz azul $(\lambda \max =488 \mathrm{~nm})$ y que emite luz verde $(\lambda \max =522 \mathrm{~nm})$.

En qPCR, la amplificación de ADN se controla en cada ciclo de PCR, y puede ser monitoreada por el software del termociclador. Cuando el ADN está en la fase logarítmica lineal de amplificación, la cantidad de fluorescencia aumenta por encima del fondo. El punto en el que la fluorescencia se vuelve medible se llama ciclo umbral $(\mathrm{Cq})$. Debido a que el valor de Cq se mide en la fase exponencial cuando los reactivos no están limitados, puede usarse para calcular de manera confiable y precisa la cantidad inicial de ADN molde presente en función de la función exponencial conocida que describe el progreso de la reacción. Este valor depende de la cantidad de ADN presente en la muestra capaz de amplificarse con los primers seleccionados. Si la cantidad inicial de $\mathrm{ADN}$ molde es alta, el Cq será bajo (a pocos ciclos emite señal fluorescente), mientras que si la cantidad de molde es baja, el Cq será alto. La cuantificación se realizó en términos relativos a un gen de referencia o housekeeping ( $\beta$ actina en este caso.) Los primers utilizados para la amplificación de este gen de referencia y de las diferentes citoquinas se muestran en la Tabla 20. El programa utilizado para la amplificación de todos los genes mencionados consistió en un primer paso de un ciclo a 50 ${ }^{\circ} \mathrm{C}$ durante $2 \mathrm{~min}$; un segundo paso de un ciclo a $90{ }^{\circ} \mathrm{C}$ durante 2 min y por último, 40 ciclos de $95{ }^{\circ} \mathrm{C}$ durante $15 \mathrm{seg}$ seguidos de $1 \mathrm{~min}$ a $60^{\circ} \mathrm{C}$. 
Tabla 20: Primers utilizados para la amplificación de citoquinas y el gen housekeeping.

\begin{tabular}{|c|c|c|}
\hline Primer & Secuencia 5'-3' & Referencia \\
\hline$\beta$-Actina & $\begin{array}{l}\text { FWD: CGTCATCCATGGCGAACTG } \\
\text { REV: GCTTCTTTGCAGCTCCTTCGT }\end{array}$ & Rumbo y col., 2004 \\
\hline TNF- $\alpha$ & $\begin{array}{l}\text { FWD: CAT CTT CTC AAA ATT CGA GTG ACA A } \\
\text { REV: CCT CCA CTT GGT GGT TTG CT }\end{array}$ & Roberts y col., 2008 \\
\hline IL-12 & $\begin{array}{c}\text { FWD: CAC ATG TCA CTG CCC GAG AGT } \\
\text { REV: GCA AAG AAA CAT GGA CTT CAA CTT C }\end{array}$ & Correa y col., 2012 \\
\hline IL-10 & $\begin{array}{l}\text { FWD: CAT TTG AAT TCC CTG GGT GAG A } \\
\text { REV: TGC TCC ACT GCC TTG CTC } \Pi \text { TT }\end{array}$ & Rolny y col., 2013 \\
\hline INF- $\nu$ & $\begin{array}{l}\text { FWD: TGG CAT AGA TGT GGA AGA AAA GAG } \\
\text { REV: TGC AGG ATT TTC ATG TCA CCA T }\end{array}$ & Correa y col. 2012 \\
\hline
\end{tabular}

\subsubsection{Extracción de ADN de heces}

La extracción de ADN de heces se realizó de acuerdo a las instrucciones del fabricante del kit. El kit de extracción utilizado fue QIAmp DNA stool kit (Qiagen, EEUU).

Se pesaron $200 \mathrm{mg}$ de materia fecal en un tubo de 1,5 ml, se agregó 1,4ml de buffer ASL (Qiagen, EEUU) y se homogeneizó en vortex por 1 min. Una vez homogeneizada, la mezcla se llevó a $80{ }^{\circ} \mathrm{C}$ en un baño termostatizado durante 5 minutos. Luego la muestra fue centrifugada y se tomaron 1,2 $\mathrm{ml}$ del sobrenadante, los cuales fueron colocados en un nuevo tubo, al cual se le agrego una tableta InhibitEX (Qiagen, EE.UU.) que adsorbe los posibles inhibidores presentes en la muestra. La muestra fue homogeneizada en vortex hasta que la tableta se disolvió completamente y luego se dejó incubar a temperatura ambiente durante 2 min para permitir la adsorción. Una vez transcurrida la incubación la muestra fue centrifugada a $11200 \mathrm{x}$ g durante 3 min para precipitar los inhibidores adsorbidos a la matriz de la tableta. Se tomaron $200 \mu \mathrm{l}$ del sobrenadante obtenido y se colocaron en un nuevo tubo de $1,5 \mathrm{ml}$ conteniendo $1,5 \mu \mathrm{l}$ de solución de proteinasa $\mathrm{K}$, y luego se agregaron también 200 
$\mu l$ de buffer AL (Qiagen, EEUU) y se homogeneizo con vortex. Posteriormente, se realizó una incubación a $70{ }^{\circ} \mathrm{C}$ durante 10 minutos para permitir la acción de la proteinasa $\mathrm{K}$ y lograr un lisado de las células. Tras la incubación, se agregaron $200 \mu \mathrm{l}$ de etanol $96 \%$, se homogeneizó con vortex y se colocó la mezcla obtenida en una columna QIamp mini spin (Qiagen, EEUU). La columna conteniendo el lisado fue centrifugada durante 1 minuto a 11200 x g, y se descartó el líquido que se filtró a través de la columna. La columna fue lavada 2 veces consecutivas con $500 \mu 1$ de buffer AW1 y AW2 respectivamente. Por último, el ADN unido a la columna fue eluido en un nuevo tubo de 1,5 ml. utilizando $200 \mu \mathrm{l}$ de buffer AE. El ADN eluido fue conservado a $-80{ }^{\circ} \mathrm{C}$ hasta su uso.

\subsubsection{Análisis por DGGE}

\subsection{Amplificación de región del gen ARNr 16S}

La secuencia de que codifica para el $\mathrm{ARNr}$ de subunidades pequeñas varía de manera ordenada a través de líneas filogenéticas y contiene segmentos que se conservan a nivel de especie, género o reino. El gen que codifica para el ARNr $16 \mathrm{~S}$ se usa a menudo para identificar diferentes especies de bacterias, ya que posee regiones conservadas y regiones hipervariables que mediante el uso de técnicas de separación como la DGGE permiten distinguir entre diferentes especies.

Se utilizó una combinación de primers (Tabla 21) que permite obtener un amplicón de aproximadamente 587 pares de bases para una región de este gen conteniendo en su secuencia una región hipervariable 
Tabla 21: Combinación de primers utilizados para la amplificación de una región de aproximadamente 587 pares de bases del gen que codifica para el ARNr16S de eubacterias. La región subrayada en el primer directo (forward) corresponde a la GC clamp necesaria para la DGGE.

\begin{tabular}{|c|c|c|}
\hline Primer & Secuencia 5'-3' & Referencia \\
\hline $\begin{array}{l}\text { GC-341f } \\
\text { (directo) }\end{array}$ & $\begin{array}{l}\text { CGC CCG CCG CGC CCC GCG CCC GGC CCG CCG CCC } \\
\text { CCG CCC CCT CCT ACG GGA GGC AGC AG }\end{array}$ & Wang y col. , 2008 \\
\hline $\begin{array}{l}907 r \\
\text { (reverso) }\end{array}$ & CCG TCA ATT CCT TTG AGT TT & Wang y col. , 2008 \\
\hline
\end{tabular}

Uno de los primers (el directo, o forward) contiene una región rica en GC (GC clamp) que es necesaria para su posterior análisis por DGGE. Antes de su uso, los primers se evaluaron in silico (http://insilico.ehu.es/PCR/) para diferentes especies bacterianas para corroborar el tamaño del amplicón originado y la posibilidad de originar hairpins, sobre todo por la existencia de la GC clamp. Las simulaciones in silico corroboraron tanto el tamaño de amplicón obtenido por Wang y col. (2008), arrojando resultados de 586 o 587 pares de bases dependiendo el microorganismo, como la especificidad de los primers, ya que esta combinación de primers generó un único amplicón para todos los microrganismos evaluados. Con respecto a la formación de dímeros de primers o hairpins, si bien la simulación indica que existe una potencial riesgo de que aparezcan, la probabilidad de ello es baja y, además, puede ser minimizada utilizando un programa con dos temperaturas de annealing: primero una más elevada que evite la formación temprana de dímeros y hairpins y luego una temperatura menor cuando la cantidad de amplicones generados en la mezcla de reacción supere a la cantidad de primers presentes en la misma.

Para la amplificación con dichos primers se utilizó una mezcla de reacción DreamTaq PCR Master Mix (Invitrogen, ThermoFisher, EEUU) como se indica en la Tabla 22. Esta Master Mix es una solución lista para usar que contiene la ADN polimerasa DreamTaq Hot Start 
(Invitrogen, ThermoFisher, EEUU), el buffer DreamTaq (optimizado para esta enzima), $\mathrm{MgCl} 2$ y dNTPs. Esta formulación premezclada ahorra tiempo y reduce la contaminación debido a un número reducido de pasos de pipeteo necesarios para la realización de la PCR.

\begin{tabular}{|c|c|}
\hline Componente & Volumen $(\mu \mathrm{l})$ \\
\hline DreamTaq PCR Master Mix & 12,5 \\
\hline Forward Primer & 1 \\
\hline Reverse Primer & 1 \\
\hline ADN molde & 2 \\
\hline Agua calidad PCR & 8,5 \\
\hline \multicolumn{2}{|c|}{ VOLUMEN FINAL DE REACCIÓN: $25 \mu \mathrm{l}$} \\
\hline
\end{tabular}

La amplificación se realizó en un termociclador BIORAD T100 (Bio-Rad Laboratories, EEUU) utilizando el programa detallado en la Tabla 23.

Tabla 23: Programa utilizado para la amplificación del gen que codifica para el ARNr 16S.

\begin{tabular}{|l|c|l|c|}
\hline \multicolumn{1}{|c|}{ Etapa } & Temperatura $\left({ }^{\circ} \mathrm{C}\right)$ & \multicolumn{1}{c|}{ Tiempo } & Nro. de Ciclos \\
\hline $\begin{array}{l}\text { Desnaturalización } \\
\text { Inicial }\end{array}$ & 94 & 4 minutos & 1 \\
\hline Desnaturalización & 94 & 30 segundos & 10 \\
\hline Hibridación & 62 & 45 segundos & \\
\hline Elongación & 72 & 60 segundos & \\
\hline Desnaturalización & 94 & 30 segundos & 25 \\
\hline Hibridación & 57 & 45 segundos & \\
\hline Elongación & 72 & 60 segundos & 1 \\
\hline Elongación Final & 72 & 10 minutos & \\
\hline
\end{tabular}

\subsection{DGGE}

Los amplicones obtenidos con los primers para el gen ARNr 16s fueron evaluados mediante electroforesis en gel con gradiente desnaturalizante (DGGE por sus siglas en inglés), un tipo de electroforesis que permite la separación de fragmentos de ADN del mismo tamaño pero con diferente secuencia de nucleótidos. 
Los perfiles obtenidos pueden analizarse para establecer la relación filogenética entre las diferentes muestras.

Para la realizar la DGGE se utilizó un equipo DGGE -2401 (C.B.S. Scientific Co., EEUU) con geles de $15 \times 20 \times 0,075 \mathrm{~cm}$. Las muestras se sembraron en geles de poliacrilamida 8 $\% \mathrm{p} / \mathrm{v}$ en buffer TAE con gradiente desnaturalizante urea-formamida 40-60 \%. La electroforesis se llevó a cabo a voltaje constante $100 \mathrm{~V}$ durante $16 \mathrm{~h}$ a $60{ }^{\circ} \mathrm{C}$. Los geles se tiñeron y visualizaron en un transiluminador GelDoc XR (BioRad, EEUU).

\subsection{Preparación de los geles y siembra}

Los vidrios dentro de los cuales se polimeriza el gel, fueron lavados exhaustivamente y secados por completo. Luego se montaron de acuerdo con las instrucciones del equipo y se comprobó que el sistema este correctamente armado y no posea perdidas utilizando agua.

Una vez constatado el correcto armado del sistema, éste fue secado cuidadosamente utilizando papel de filtro.

Para la preparación de los geles con el gradiente desnaturalizante, se utilizó un sistema de dos vasos comunicantes conectado a una bomba peristáltica. Se prepararon las soluciones desnaturalizantes de trabajo (Tabla 24) a partir de soluciones desnaturalizantes 0 y $80 \%$ (Tabla 25). Inmediatamente antes de su uso se le agregó a cada una de estas soluciones de trabajo $4.4 \mu 1$ de TEMED y $44 \mu 1$ de persulfato de amonio $10 \% \mathrm{p} / \mathrm{v}$. Las soluciones se colocaron en el sistema de vasos comunicantes, colocando aquella con mayor concentración

Tabla 24: Cantidades de soluciones $0 \%$ y $80 \%$ desnaturalizante para preparar las soluciones de trabajo.

\begin{tabular}{|c|c|c|}
\hline $\begin{array}{c}\text { Concentración } \\
\text { desnaturalizante }\end{array}$ & $\begin{array}{c}\text { Solución } 0 \% \\
\text { desnaturalizante }\end{array}$ & \begin{tabular}{c} 
Solución $80 \%$ desnaturalizante \\
\hline $\mathbf{4 0 \%}$
\end{tabular} \\
\hline $\mathbf{6 0 \%}$ & $5,75 \mathrm{ml}$ & $5,75 \mathrm{ml}$ \\
\hline
\end{tabular}


de urea -formamida en el vaso más cercano al conducto de salida y agitando durante la preparación del gel con un agitador magnético.

Las soluciones fueron luego vertidas entre los vidrios mediante una bomba peristáltica a mínima velocidad. Una vez lleno el volumen entre los dos vidrios, se colocó el peine para formar las calles y se dejó polimerizar el gel en un lugar fresco y seco.

Tabla 25: Componentes y cantidades para preparar las soluciones desnaturalizantes $0 \%$ y $80 \%$.

\begin{tabular}{|l|l|l|}
\hline Componente & $0 \%$ desnaturalizante & $80 \%$ desnaturalizante \\
\hline Acrilamida-Bis $40 \%$ & $20 \mathrm{ml}$ & $20 \mathrm{ml}$ \\
\hline Buffer TAE $50 \mathrm{X}$ & $2 \mathrm{ml}$ & $2 \mathrm{ml}$ \\
\hline Urea & - & $33,6 \mathrm{~g}$ \\
\hline Formamida deionizada & - & $32 \mathrm{ml}$ \\
\hline Agua destilada & c.s.p. $100 \mathrm{ml}$ & c.s.p. $100 \mathrm{ml}$ \\
\hline
\end{tabular}

Debido a que el gel se contrae durante la polimerización, se utilizó solución stacking para completar el volumen perdido y se dejó polimerizar nuevamente. Esta solución de stacking permite además que la muestra ingrese en una banda bien definida al gel desnaturalizante.

Una vez formado el gel, los vidrios conteniendo el mismo se montaron sobre el soporte correspondiente y se colocaron en la cuba con buffer TAE a $60^{\circ} \mathrm{C}$. Luego se sembraron en cada fosa $20 \mu \mathrm{l}$ de muestra con $5 \mu \mathrm{l}$ de buffer siembra.

\subsection{Tinción y análisis}

Una vez finalizada la electroforesis los soportes conteniendo los geles fueron retirados de la cuba y desmontados. Se separaron luego los vidrios que contienen el gel de modo tal que el gel quede sobre uno de estos vidrios. Para la tinción, el gel sobre el vidrio se colocó en una cuba conteniendo una solución de Sybr Gold 0,2 $\mu \mathrm{l} / \mathrm{ml}$ en buffer TAE durante 30 min.

Luego de finalizada la tinción, el gel fue separado cuidadosamente del vidrio y colocado en un transiluminador UV con cámara fotográfica acoplada GelDoc XR (BioRad, EEUU). Las 
fotografías obtenidas fueron analizadas posteriormente utilizando el software GelCompar II (AppliedMaths, bioMérieux, Francia).

\subsubsection{Análisis por secuenciación}

A partir de las muestras de ADN de heces se realizaron 4 pooles (1 para cada condición evaluada en el experimento), conteniendo cantidades iguales de cada una de las muestras.

Los pooles obtenidos fueron enviados a secuenciar a MRDNA Labs (Texas, EEUU) para conocer la abundancia relativa de las distintas bacterias presentes en la microbiota intestinal. La secuenciación fue dirigida al gen 16S rRNA y se realizó utilizando la tecnología Illumina MISeq.

Las secuencias obtenidas fueron analizadas con el software GeneIOUS (Biomatters, Nueva Zelandia) y una vez eliminadas las secuencias quimera y/o incompletas, las unidades taxonómicas operacionales (OTU: del inglés operational taxonomic unit) obtenidas se compararon con la base de datos de NCBI. En los análisis de metagenómica se conoce como OTU a un grupo de variantes de secuencia similares de la secuencia del gen marcador de 16S rRNA. Cada uno de estos grupos está destinado a representar una unidad taxonómica de una especie o género de bacterias dependiendo que tan similares sean sus secuencias, de acuerdo a un umbral prestablecido. Por lo general, cada OTU se define por un umbral de identidad del 97\% de las secuencias del gen 16S para distinguir las bacterias a nivel de género. La abundancia relativa se calculó contabilizando todas las OTU obtenidas en el análisis.

\subsubsection{Análisis estadístico}

El análisis de la varianza (ANOVA) de los recuentos de viables correspondientes a los diversos tratamientos se realizó usando el programa estadístico Statgraphics Centurion XVII (Statistical Graphics Corp, EEUU). Se realizó la comparación de medias por el método de 
Tukey, considerando como estadísticamente significativa cuando $p<0.05$. Los gráficos fueron realizados utilizando el software GraphPad Prism 6 (GraphPad Software, EEUU). 


\subsection{RESULTADOS Y DISCUSIÓN}

\subsubsection{Estudios in vitro}

\subsubsection{Ensayos de proliferación de Giardia}

El primer paso para establecer si los productos desarrollados en el presente trabajo de tesis poseen un efecto sobre el parásito, es verificar si afecta su normal proliferación.

Para este tipo de desafíos, se emplearon tanto los productos desarrollados por secado spray, como cultivos frescos ya sea de kefir o de una cepa aislada de éste: L. plantarum CIDCA 83114. Estos cultivos frescos fueron realizados tanto en su medio de cultivo tradicional (leche UHT y MRS, para kefir y la cepa aislada respectivamente), como en medio MTYI, una modificación del medio TYI-S-33 que permite el crecimiento tanto del parásito como de bacterias lácticas (Pérez y col., 2001) y en permeado de suero al $20 \%$.

Además, también se desafió con L. plantarum CIDCA 83114 crecido en permeado de suero $20 \%$ y deshidratado por secado spray directamente (sin el agregado de carriers).

La cepa L. plantarum CIDCA 83114 posee una alta resistencia al pasaje por el tracto gastrointestinal en ensayos in vitro (Golowczyc y col., 2008); se adhiere a células en cultivo y antagoniza con diversos patógenos intestinales como Salmonella, E.coli y Shigella (Golowczyc y col., 2008; Hugo y col., 2008; Kakisu y col., 2013; Bolla y col., 2016). Además, posee la capacidad de secuestrar aflatoxina AFB1 (León Peláez, 2013) y de reducir la actividad de la toxina shiga (Kakisu y col., 2012). Por otro lado, L plantarum 83114 sobrevive al secado en spray en un rango de temperatura de salida de 75 a $85^{\circ} \mathrm{C}$ y posee gran estabilidad durante el almacenamiento a $4{ }^{\circ} \mathrm{C}$ (Golowczyc y col., 2010).

La cepa deshidratada por secado en spray no evidenció daño en la membrana, ni cambios en la capacidad de acidificar el medio MRS, ni pérdida de la capacidad de adhesión a células in vitro (Golowczyc y col., 2011). 
El permeado de suero resultó ser un sustrato adecuado para el cultivo de esta cepa sin necesidad de suplementación con fuentes adicionales de carbono o nitrógeno lo cual resulta muy ventajoso considerando que es un efluente de la industria láctea (Hugo y col., 2016).

La cepa L. plantarum CIDCA 83114 crecida en permeado de suero $20 \%(\mathrm{p} / \mathrm{v})$ fue deshidratada por secado spray con las condiciones empleadas en la primera parte y administrada en agua de bebida de los ratones. El producto obtenido mostró una viabilidad microbiana de $8 \log \mathrm{UFC} / \mathrm{g}$ y una aW de 0,27 , parámetros que mantuvo prácticamente inalterados durante 30 días de ensayo de almacenamiento a $4{ }^{\circ} \mathrm{C}$ (Figura 33). Además, mostró conservar su capacidad acidificante, disminuyendo el $\mathrm{pH}$ de leche UHT hasta $\mathrm{pH}=$ 4,09 tras 24 horas de incubación a $20^{\circ} \mathrm{C}$. Teniendo en cuenta el consumo diario de agua de cada animal y la concentración de producto deshidratado, la dosis estimada de microorganismos administrados fue de $5 \times 10^{7}$ UFC por animal/día.
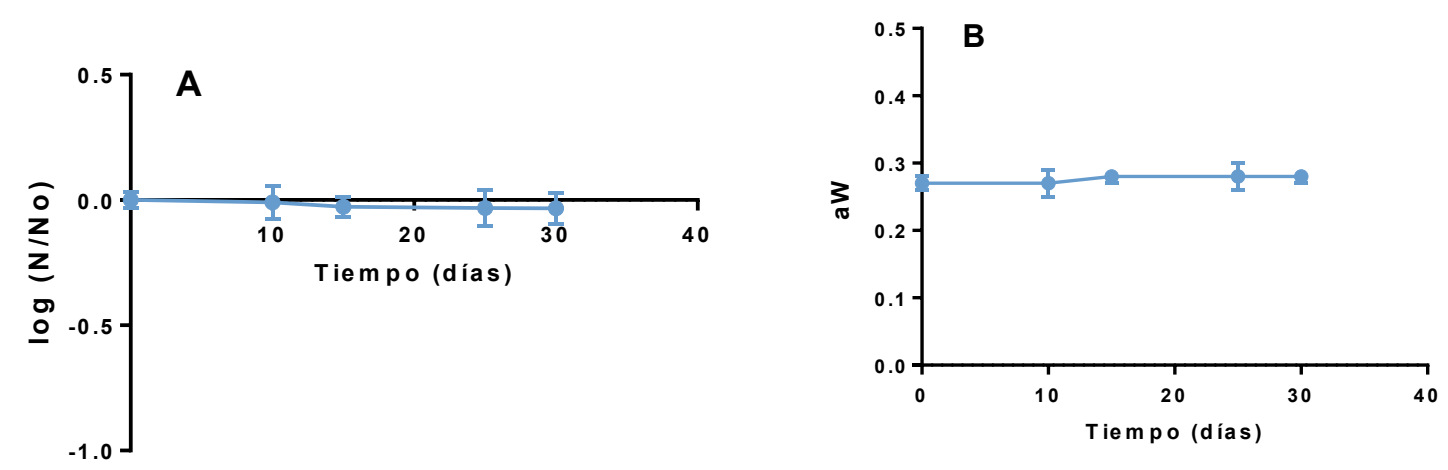

Figura 33: Supervivencia microbiana (A) y aW (B) durante el almacenamiento a $4^{\circ} \mathrm{C}$ para el producto deshidratado elaborado a partir de L. plantarum CIDCA 83114 en permeado de suero 20 $\%(\mathrm{p} / \mathrm{v})$. Los resultados graficados representan el promedio de por lo menos dos ensayos independientes. Las barras representan la desviación estándar.

Los resultados obtenidos para los ensayos de proliferación con los diferentes sobrenadantes se muestran en la figura 34 : 


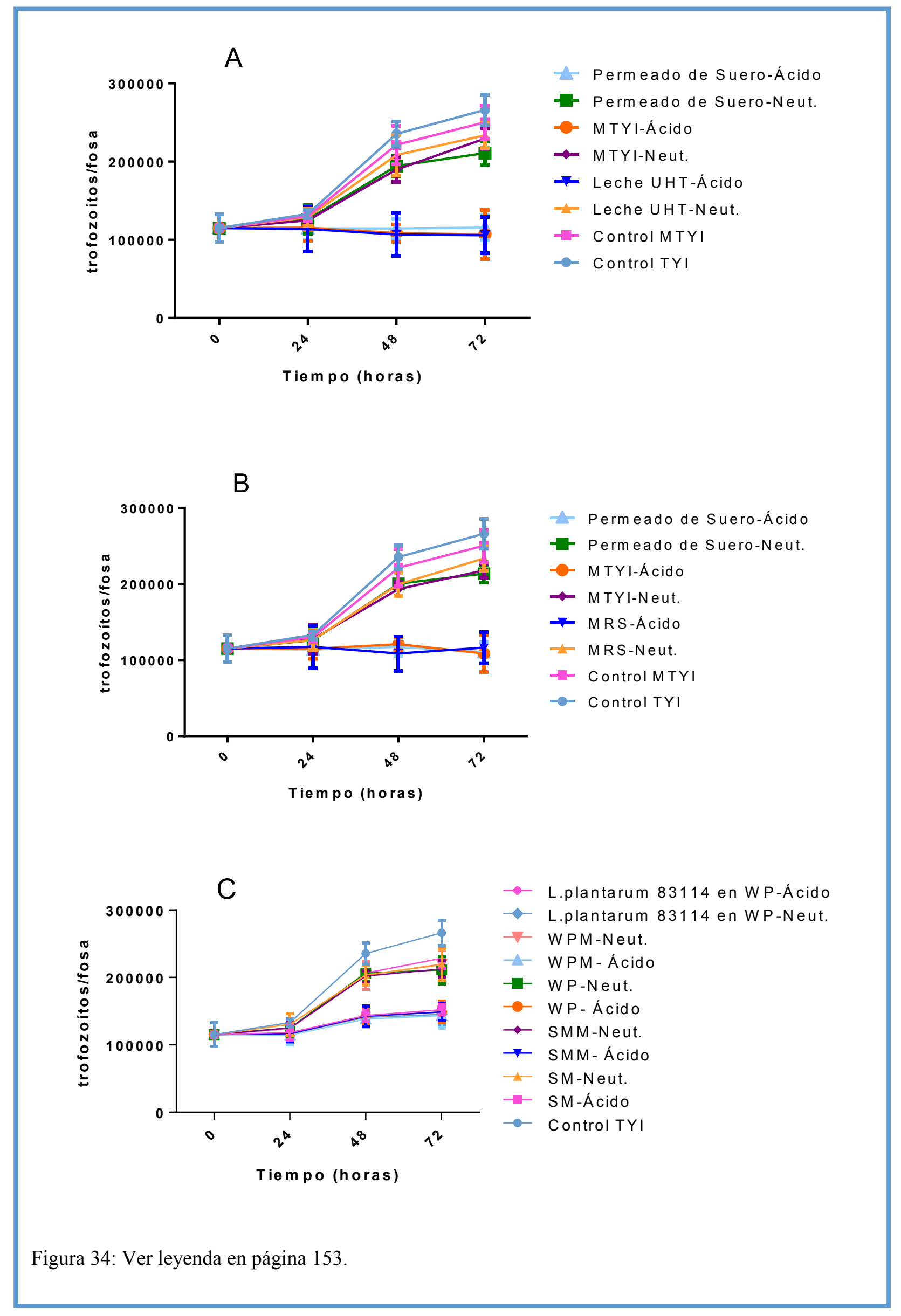


Figura 34: Proliferación de trofozoitos de Giardia intestinalis $\mathrm{H} 7$ en presencia de sobrenadantes neutralizados (Neut.) y sin neutralizar (Ácido) provenientes de: (A) cultivos frescos de kefir en leche UHT, MTYI y permeado de suero $20 \%$; (B) cultivos frescos de L.plantarum CIDCA 83114 en MRS, MTYI y permeado de suero $20 \%$; y (C) de algunos de los productos deshidratados elaborados en la primer parte del presente trabajo (Ver Tabla Resumen de Muestras). Como controles se utilizaron los medios TYI-S-33 (TYI) y MTYI. Los valores graficados corresponden a por lo menos 3 ensayos independientes.

Se evidencia una fuerte relación entre el $\mathrm{pH}$ de la muestra y la proliferación de los trofozoitos. Los sobrenadantes neutralizados, ya sea que provengan de cultivos frescos o deshidratados permitieron una proliferación normal del parásito; mientras que los sobrenadantes que no fueron neutralizados tuvieron un efecto adverso significativo ( $p<$ $0,05)$ sobre la proliferación de Giardia. Este efecto puede atribuirse al $\mathrm{pH}$ debido a que el

Tabla 26: Valores de $\mathrm{pH}$ y recuentos de trofozoitos promedio por fosa para los cultivos de Giardia en presencia de los sobrenadantes provenientes de cultivos de kefir o L.plantarum CIDCA 83114 en diferentes medios. Neut. indica que fueron neutralizados previo al ensayo. Los valores de la tabla corresponden a por lo menos tres ensayos independientes.

\begin{tabular}{|l|c|c|}
\hline $\begin{array}{l}\text { Procedencia sobrenadante } \\
\text { (o Control) }\end{array}$ & $\mathrm{pH}$ (72hs) & TROFOZOITOS/fosa (72hs) \\
\hline Control TYI & 7,05 & $2,66 \times 10^{5}$ \\
\hline Control MTYI & 7,00 & $2,50 \times 10^{5}$ \\
\hline Kefir en leche UHT Neut. & 6,98 & $2,34 \times 10^{5}$ \\
\hline Kefir en leche UHT & 4,03 & $1,06 \times 10^{5}$ \\
\hline L.plantarum en MRS Neut. & 7,00 & $2,34 \times 10^{5}$ \\
\hline L.plantarum en MRS & 4,15 & $1,16 \times 10^{5}$ \\
\hline Kefir en MTYI Neut. & 6,96 & $2,29 \times 10^{5}$ \\
\hline Kefir en MTYI & 4,09 & $1,07 \times 10^{5}$ \\
\hline L.plantarum en MTYI Neut. & 6,98 & $2,18 \times 10^{5}$ \\
\hline L.plantarum en MTYI & 4,12 & $1,08 \times 10^{5}$ \\
\hline $\begin{array}{l}\text { Kefir en permeado de suero } \\
\text { 20\%p/v Neut. }\end{array}$ & 6,96 & $2,11 \times 10^{5}$ \\
\hline $\begin{array}{l}\text { Kefir en permeado de suero } \\
\text { 20\%p/v }\end{array}$ & 4,06 & $1,16 \times 10^{5}$ \\
\hline $\begin{array}{l}\text { L.plantarum en permeado de } \\
\text { suero 20\%p/v Neut. }\end{array}$ & 6,96 & $2,13 \times 10^{5}$ \\
\hline $\begin{array}{l}\text { L.plantarum en permeado de } \\
\text { suero 20\%p/v }\end{array}$ & 4,10 & $1,10 \times 10^{5}$ \\
\hline & & \\
\hline
\end{tabular}


parásito necesita para su óptimo desarrollo un $\mathrm{pH}$ entre 6,4 y 7,2. Los sobrenadantes frescos presentan un valor de $\mathrm{pH}$ cercano a 4 (Tabla 26), lo que explicaría la forma de las curvas correspondientes a dichas muestras observadas en la Figura 34.

Tabla 27: Valores de $\mathrm{pH}$ y recuentos de trofozoitos promedio por fosa para los cultivos de Giardia en presencia de sobrenadantes provenientes de productos deshidratados (ver Tabla Resumen Muestras). Neut. indica que fueron neutralizados previo al ensayo. Los valores de la tabla corresponden a por lo menos tres ensayos independientes.

\begin{tabular}{|l|c|c|}
\hline Muestra & pH (72 hs) & TROFOZOITOS/fosa (72 hs) \\
\hline SM & 5,90 & $1,52 \times 10^{5}$ \\
\hline SM Neut. & 6,96 & $2,19 \times 10^{5}$ \\
\hline SMM & 5,82 & $1,49 \times 10^{5}$ \\
\hline SMM Neut. & 6,97 & $2,13 \times 10^{5}$ \\
\hline WP & 5,84 & $1,49 \times 10^{5}$ \\
\hline WP Neut. & 6,95 & $2,11 \times 10^{5}$ \\
\hline WPM & 5,76 & $1,43 \times 10^{5}$ \\
\hline WPM Neut. & 6,97 & $2,20 \times 10^{5}$ \\
\hline L.plantarum en permeado de suero & 5,78 & $1,45 \times 10^{5}$ \\
\hline 20\%p/v deshidratado & & $2,28 \times 10^{5}$ \\
\hline L. plantarum en permeado de suero & 6,90 & \\
\hline 20\%p/v deshidratado Neut. & & \\
\hline
\end{tabular}

Para los sobrenadantes de los productos deshidratados, los valores de $\mathrm{pH}$ fueron cercanos a 5,8 (Tabla 27) y, si bien la cantidad de trofozoitos por fosa fue mayor, esta diferencia no fue estadísticamente significativa respecto a lo observado cuando se utilizaron sobrenadantes provenientes de los productos frescos, poniendo de manifiesto nuevamente la sensibilidad de Giardia al pH.

Para mantener su $\mathrm{pH}$ interno en un rango apropiado, Giardia utiliza mecanismos de transporte activo para enviar protones hacia el exterior celular. Estos mecanismos ayudan a que en el interior celular el pH se conserve en su rango homeostático entre 6,7 y 7,1 (Biagini y col. 2001). Cuando se evaluaron las fracciones microbianas tanto de los productos frescos como de los deshidratados, las bacterias acidificaron rápidamente el medio, llevando el pH 
por debajo del valor óptimo para la proliferación de Giardia tras 24 horas de ensayo (Tablas 28 y 29$)$.

Tabla 28: Valores de $\mathrm{pH}$ a las 24 horas de ensayo para los cultivos de Giardia en presencia de los microorganismos provenientes de cultivos de kefir o L. plantarum CIDCA 83114 en diferentes medios. Los valores de la tabla corresponden al promedio de por lo menos tres ensayos independientes.

\begin{tabular}{|l|c|}
\hline Muestra & pH (24 hs) \\
\hline Control TYI & 6,8 \\
\hline Control MTYI & 6,8 \\
\hline Kefir en leche UHT & 4,3 \\
\hline L. plantarum en MRS & 4,6 \\
\hline Kefir en MTYI & 4,4 \\
\hline L. plantarum en MTYI & 4,4 \\
\hline Kefir en permeado de suero 20\%p/v & 4,3 \\
\hline L. plantarum en permeado de suero 20\%p/v & 4,5 \\
\hline
\end{tabular}

Un valor de $\mathrm{pH}$ bajo hace que el parásito utilice mucha energía para mantener la homeostasis interna, dejando en segundo plano otras funciones que requieren energía, como la reproducción o el movimiento (que es esencial para la adhesión). Los parásitos crecidos en presencia de los microorganismos provenientes de los diferentes cultivos realizados o de los productos deshidratados evidenciaron alteraciones morfológicas y del movimiento, lo cual está de acuerdo con la hipótesis expuesta. 
Tabla 29: Valores de $\mathrm{pH}$ a las 24 horas de ensayo para los cultivos de Giardia en presencia de los microorganismos provenientes de productos deshidratados (ver Tabla Resumen Muestras) con las que se realizó el ensayo de proliferación. Los valores de la tabla corresponden al promedio de por menos tres ensayos independientes.

\begin{tabular}{|l|c|}
\hline Muestra & pH (24hs) \\
\hline SM & 5,0 \\
\hline SMM & 4,9 \\
\hline SMN & 5,2 \\
\hline SMMN & 5,3 \\
\hline WP & 4,5 \\
\hline WPM & 4,6 \\
\hline WPN & 5,2 \\
\hline WPMN & 5,3 \\
\hline L. plantarum en permeado de suero 20\% p/v & 4,4 \\
\hline deshidratado & \\
\hline MT & 4,8 \\
\hline MTN & 5,3 \\
\hline WPT & 4,7 \\
\hline WPTN & 5,4 \\
\hline SMT & 4,8 \\
\hline SMTN & 5,4 \\
\hline
\end{tabular}

\subsubsection{Ensayos de adhesión a células}

La supervivencia del parásito en el tracto gastrointestinal está íntimamente relacionada con su adhesión a la superficie celular, evitando que sea arrastrado por el flujo intestinal y los movimientos de peristalsis. (Ceu Sousa y col. 2001). Esta adhesión está mediada por la acción del disco suctorio ventral y por la acción de moléculas tipo lectina (Magne y col., 1991; Sreenivas y col., 1995). Los sobrenadantes de kefir o de cepas aisladas del mismo suelen contener metabolitos bioactivos que podrían modificar esta capacidad de adhesión. Así, un esquema experimental en el que se incuben los trofozoitos con los sobrenadantes de kefir (o de productos elaborados a partir del mismo) podría poner en evidencia efectos sobre la adhesión del parásito a las células. 
Se realizaron entonces ensayos de adhesión a células Caco-2-TC7 (Humen, 2009) con trofozoitos de Giardia que habían sido preincubados con sobrenadantes neutralizados provenientes de productos fermentados frescos o de algunos de los productos deshidratados desarrollados en el presente trabajo de tesis. Los sobrenadantes utilizados para estos ensayos fueron siempre neutralizados y filtrados previo a su uso, debido a que un bajo $\mathrm{pH}$ tiene un efecto adverso tanto para Giardia (como se observó en los ensayos de proliferación) como para la integridad de la monocapa celular.

Como primera aproximación, la preincubación fue realizada en una relación 1:3 (una parte de sobrenadante neutralizado y filtrado; 3 partes suspensión de Giardia en DMEM de adhesión) y se utilizaron $\mathrm{MDI}=1$ y $\mathrm{MDI}=2$. Como podemos observar en las Figuras 35 y 36 , la preincubación en relación 1:3 no ejerce un efecto apreciable sobre la adhesión del parásito a la célula. Todos los pretratamientos mostraron un número de trofozoitos adheridos similar al control tanto para MDI=1 (Figura 35) como para MDI=2 (Figura 36). 


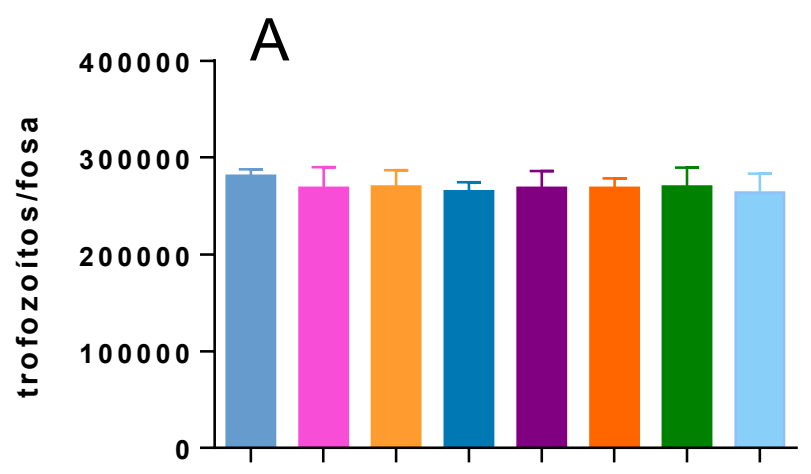

\section{Control (PBS)}

Permeado de suero $20 \% \mathrm{p} / \mathrm{v}$ filtrado

Kefir en leche UHT

L. plantarum 83114 en MRS

Kefir en MTYI

L. plantarum 83114 en MTYI

Kefir enpermeado de suero $20 \% \mathrm{p} / \mathrm{v}$

L. plantarum 83114 en permeado

de suero $20 \% \mathrm{p} / \mathrm{v}$

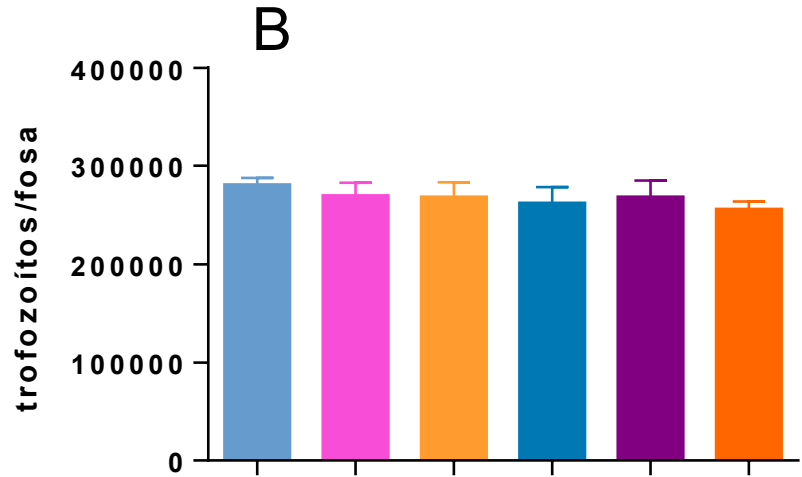

Control (PBS)

SM

SMM

W P

WPM

L. plantarum 83114 en

permeado de suero $20 \% \mathrm{p} / \mathrm{v}$

deshidratado

Figura 35: Adhesión de trofozoitos de Giardia intestinalis $\mathrm{H} 7$ a células CaCo-2-TC7 (MDI=1) tras ser preincubados en una relación 1:3 con sobrenadantes neutralizados provenientes de cultivos frescos de kefir en leche UHT, MTYI o permeado de suero $20 \%$ p/V o L. plantarum CIDCA 83114 en MRS, MTYI y permeado de suero $20 \% \mathrm{p} / \mathrm{V}$ (A); o con sobrenadantes neutralizados provenientes de algunos de los productos deshidratados desarrollados para el presente trabajo de tesis - ver Tabla Resumen de Muestras(B). Como control se utilizó PBS para la preincubación. Los resultados corresponden a por los menos 3 ensayos independientes. Las barras de erros corresponden a la desviación estándar entre las diferentes muestras. 

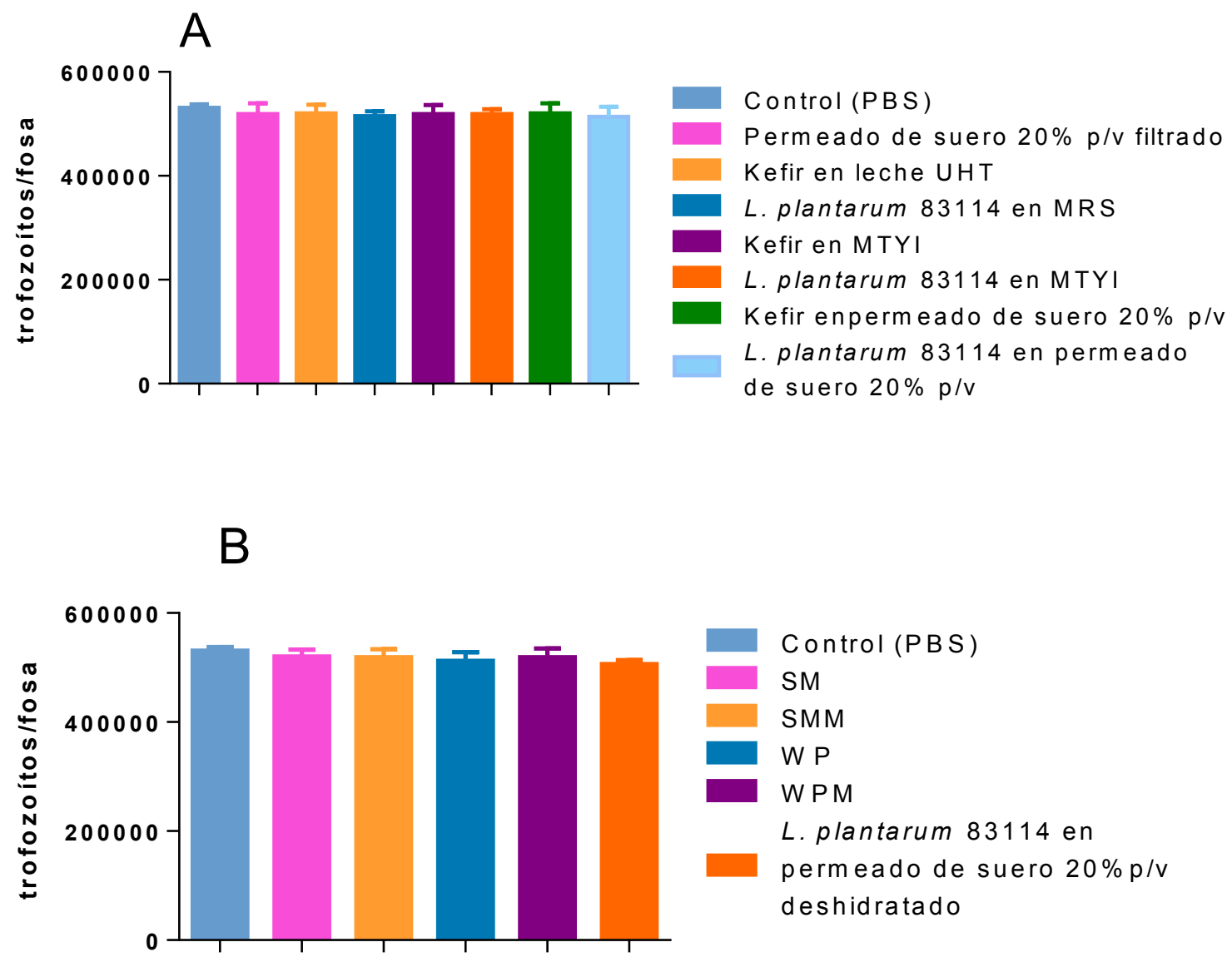

Figura 36: Adhesión de trofozoitos de Giardia intestinalis $\mathrm{H7}$ a células CaCo-2-TC7 (MDI=2) tras ser preincubados en una relación 1:3 con sobrenadantes neutralizados provenientes de cultivos frescos de kefir en leche UHT, MTYI o permeado de suero $20 \%$ p/V o L. plantarum CIDCA 83114 en MRS, MTYI y permeado de suero $20 \% \mathrm{p} / \mathrm{V}$ (A) o con sobrenadantes neutralizados provenientes de algunos de los productos deshidratados desarrollados para el presente trabajo de tesis - ver Tabla Resumen de Muestras- (B). Como control se utilizó PBS para la preincubación. Los resultados corresponden a por los menos 3 ensayos independientes. Las barras de erros corresponden a la desviación estándar entre las diferentes muestras. 
Se incrementó entonces la proporción del sobrenadante, pasando a una relación 1:1 (una parte de sobrenadante neutralizado y filtrado; una parte de suspensión de Giardia en DMEM de adhesión), sospechando que la ausencia de un efecto antiadherente podía deberse a una baja concentración de factores extracelulares presentes en dicho sobrenadante. Como se puede observar en las figuras 37 y 38, la adhesión de los trofozoitos de Giardia a la célula no se vio afectada por un incremento en la cantidad de sobrenadante durante la preincubación para ninguna de las dos MDI evaluadas. Los valores de adhesión para las MDI ensayadas concuerdan con los observados por Humen (2009) durante la puesta a punto de este modelo celular (Caco-TC7) para la adhesión con trofozoitos de Giardia intestinalis H7. Pérez y col. (2001), encontraron que la coincubación de trofozoitos con sobrenadantes de la cepa $L$. johnsonii LA1 neutralizados causaba la detención del ciclo celular de los trofozoitos en fase G1, sin embargo, la adhesión de los mismos a las células no presentó cambios. Estos trofozoitos, sin embargo, perdían su morfología normal y su capacidad de movimiento, lo que indica que existe adhesión de los parásitos a las células pese a que el ciclo celular esté detenido.

En el presente trabajo de tesis no se observaron diferencias de adhesión en los trofozoitos tratados con sobrenadantes neutralizados. Esto indica que la funcionalidad de los trofozoitos para el proceso de adhesión está conservada lo cual implica morfología y movilidad normales de los parásitos. Sin embargo, como fuera demostrado por Humen (2009), las células epiteliales presentan alteraciones estructurales y funcionales como consecuencia de la adhesión de los trofozoitos. En consecuencia, marcadores relacionados con las proteínas de unión intercelular resultan más apropiados para profundizar los estudios del posible efecto protector de los sobrenadantes y/o productos. 


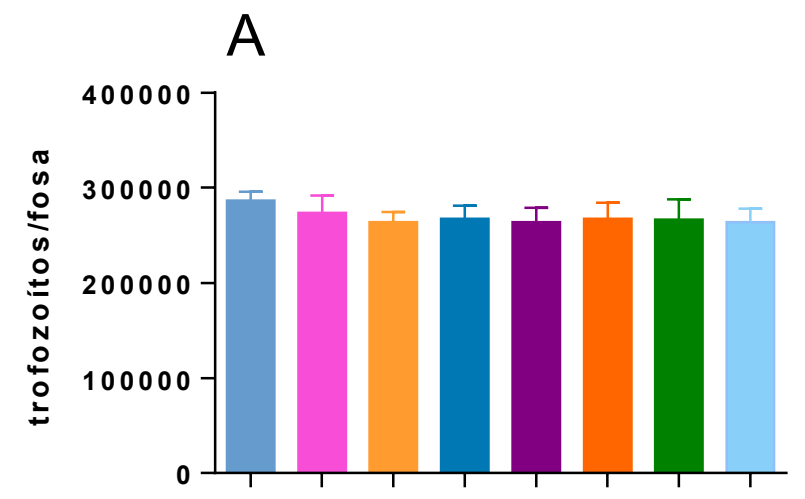

Control (PBS)

Permeado de suero $20 \% \mathrm{p} / \mathrm{v}$ filtrado

Kefir en leche UHT

L. plantarum 83114 en MRS

Kefir en MTYI

L. plantarum 83114 en MTYI

Kefir enpermeado de suero $20 \% \mathrm{p} / \mathrm{v}$

L. plantarum 83114 en permeado

de suero $20 \% \mathrm{p} / \mathrm{v}$

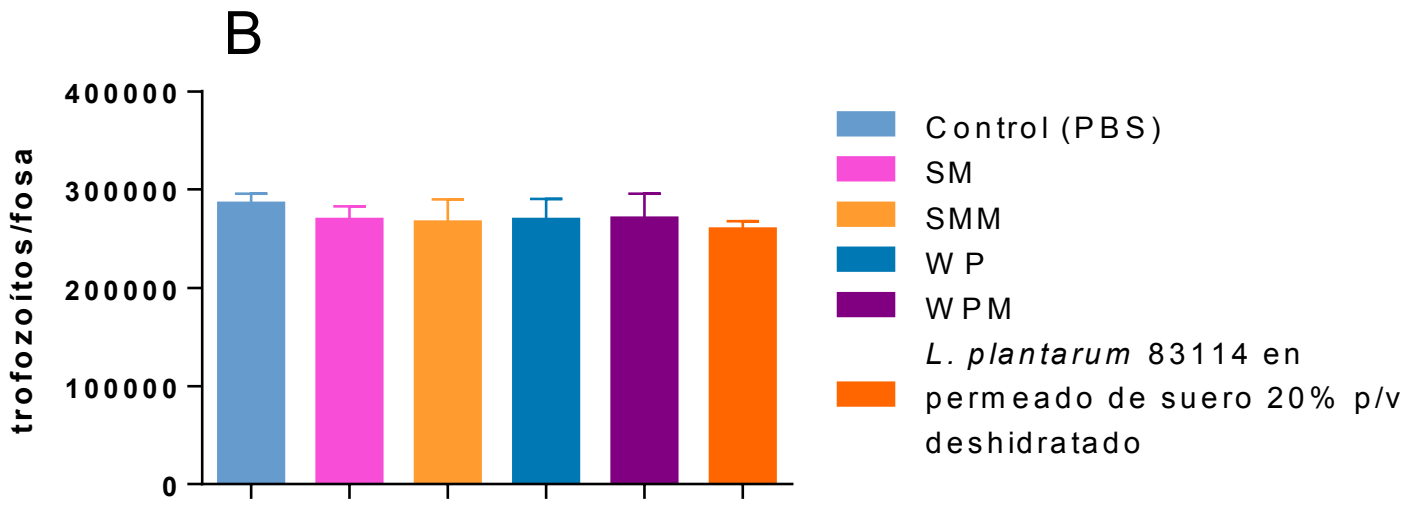

Figura 37: Adhesión de trofozoitos de Giardia intestinalis $\mathrm{H} 7$ a células CaCo-2-TC7 (MDI=1) tras ser preincubados en una relación 1:1 con sobrenadantes neutralizados provenientes de cultivos frescos de kefir en leche UHT, MTYI o permeado de suero $20 \%$ p/V o L. plantarum CIDCA 83114 en MRS, MTYI y permeado de suero $20 \% \mathrm{p} / \mathrm{V}$ (A) o con sobrenadantes neutralizados provenientes de algunos de los productos deshidratados desarrollados para el presente trabajo de tesis - ver Tabla Resumen de Muestras- (B). Como control se utilizó PBS para la preincubación. Los resultados corresponden a por los menos 3 ensayos independientes. Las barras de erros corresponden a la desviación estándar entre las diferentes muestras. 


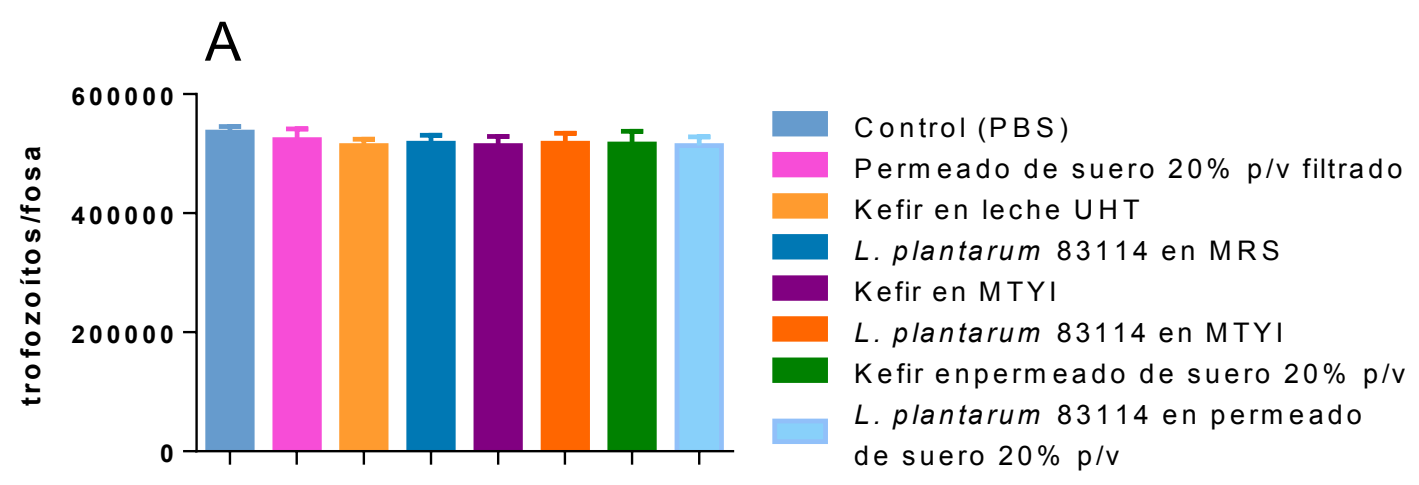

B

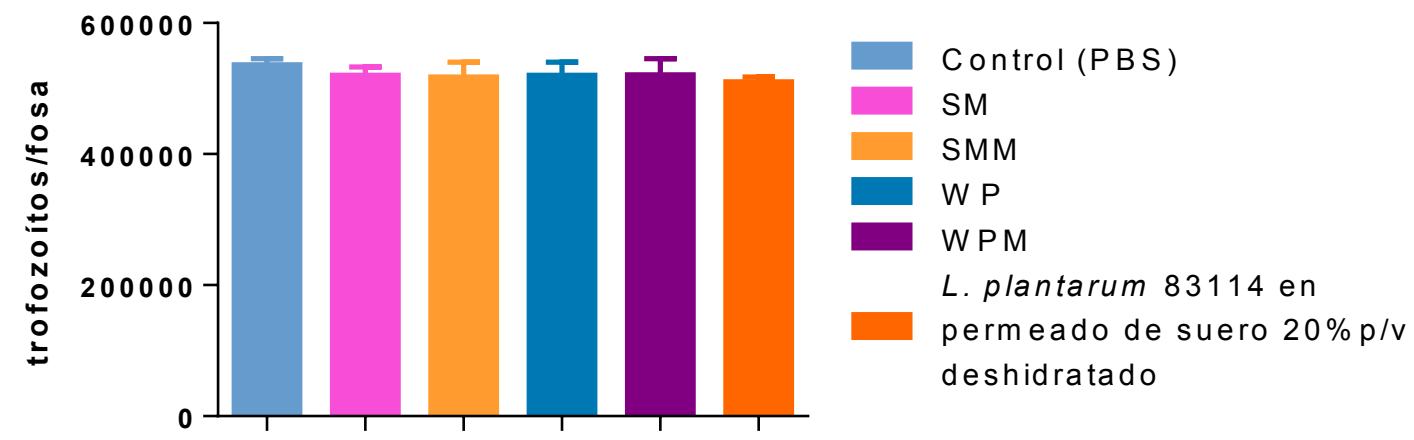

Figura 38: Adhesión de trofozoitos de Giardia intestinalis $\mathrm{H7}$ a células CaCo-2-TC7 (MDI=2) tras ser preincubados en una relación 1:1 con sobrenadantes neutralizados provenientes de cultivos frescos de kefir en leche UHT, MTYI o permeado de suero $20 \% \mathrm{p} / \mathrm{V}$ o L. plantarum CIDCA 83114 en MRS, MTYI y permeado de suero $20 \%$ p/V (A) o con sobrenadantes neutralizados provenientes de algunos de los productos deshidratados desarrollados para el presente trabajo de tesis - ver Tabla Resumen de Muestras- (B). Como control se utilizó PBS para la preincubación. Los resultados corresponden a por los menos 3 ensayos independientes. Las barras de erros corresponden a la desviación estándar entre las diferentes muestras. 
Por último, se intentó evaluar el efecto de las los microorganismos presentes en los diferentes productos deshidratados elaborados sobre la adhesión, pero observamos limitaciones en modelo de estudio escogido. Dichas limitaciones estuvieron relacionadas con la imposibilidad de separar totalmente las bacterias provenientes de las muestras de los trofozoitos tras la preincubación. Así, las bacterias que son arrastrados junto con los trofozoitos luego de la preincubación, acidifican el medio de cultivo durante la coincubación con las células dando lugar a desarreglos/desprendimientos en la monocapa celular, que imposibilitan evaluar el grado de adhesión del parásito. Además, esta acidificación del medio generó alteraciones morfológicas y de movimiento en los trofozoitos, como se observó en los ensayos de proliferación.

\subsubsection{Efecto sobre las proteinas de unión intercelular}

Se realizaron ensayos de infección de Giardia sobre el modelo celular para evaluar el efecto del parásito sobre la distribución de las proteínas de unión intercelular y si dicho efecto es modificado por la presencia de los sobrenadantes de los productos frescos o deshidratados.

Para ello se infectaron células Caco-2-TC7 desde el polo apical con trofozoitos de Giardia, en combinación o no con sobrenadante de kefir fresco o con permeado de suero

Luego de 24 h de incubación, las células fueron procesadas para la detección de las proteínas en cuestión por inmunofluorescencia indirecta, tal y como se describe en materiales y métodos (Ver 2.3.2.4.1).

El epitelio intestinal es un componente clave de la barrera intestinal, la cual es la primera línea de defensa contra sustancias o microorganismos nocivos que puedan estar presentes en los alimentos que se ingieren. La función de barrera se mantiene mediante la expresión de complejos de unión celular, que sellan las células adyacentes y proporcionan anclaje al 
citoesqueleto. Las uniones estrechas (TJ por sus siglas en inglés, tight junctions) son complejos dinámicos de múltiples proteínas que funcionan como barrera paracelular selectiva / semipermeable, que facilita el paso de iones y solutos a través del espacio intercelular, al tiempo que evita la translocación de antígenos luminales, microorganismos y sus toxinas.

La expresión de proteínas de los complejos de unión en el intestino está altamente regulada y depende de compartimento intestinal (intestino delgado o grueso), localización de vellosidades / criptas y especificidad de la membrana celular (apical, lateral o basolateral). El patrón complejo de la expresión de las proteínas de unión estrecha en el intestino está relacionado con las funciones específicas de una región intestinal particular $\mathrm{y}$ su localización. Además, la actividad y localización de estas proteínas está regulada por la fosforilación, la cual puede promover la formación de TJ y la función de barrera, o alternativamente promover la redistribución de proteínas TJ y la desestabilización de los complejos de unión (Furuse y col. 1993; Groschwitz y Hogan. 2009; Zihni y col., 2016).

Observaciones de modelos in vitro e in vivo han establecido que los parásitos como Giardia aumentan la permeabilidad intestinal. (Dagci y col., 2002; Scott y col., 2002; Buret, 2007). Este hecho es de gran relevancia clínica, ya que se ha demostrado que esta pérdida de la función barrera en el epitelio intestinal resulta en un aumento de la absorción de antígenos luminales, generando así diversas patologías como IBD (del inglés: Intestinal Bowel Disease - Enfermedad inflamatoria intestinal), enfermedad de Crohn o colitis ulcerosa (Catalioto, 2011).

Varios autores observaron que la pérdida de la función barrera en el epitelio intestinal asociada a la infección por Giardia se relacionaba con diversos cambios en las estructuras celulares, como modificaciones en el esqueleto de F-actina y modificaciones en la 
distribución de las proteínas presentes en los complejos de unión estrecha, como ocludina y claudina-1 (Scott y col., 2002; Humen y col., 2011). Así resulta de interés evaluar la distribución de estas proteínas de unión estrecha ante la infección por parte de Giardia en un modelo celular e indagar acerca de la acción del sobrenadante de kefir en este modelo.

Para este trabajo se hizo foco en dos proteínas que forman parte de las uniones estrechas de los enterocitos: claudina-1 y ocludina.

La ocludina es una proteína integral de las uniones estrechas de epitelios y endotelios. Posee cuatro dominios transmembrana, tres citoplasmáticos, y dos loops extracelulares. Esta proteínas se une a ZO-1 (zona occludens 1) formando un puente con el citoesqueleto de actina (Madara, 1987). Claudina-1 es una proteína de la familia de las claudinas que se encuentra en epitelios con alta resistencia eléctrica transepitelial (TEER, del inglés: Transepithelial Electrical Resistance) donde co-localiza con ocludina, y una combinación de ambas proteínas es necesaria para el establecimiento de una barrera paracelular efectiva (Furuse y col., 2002). La deslocalización de estas proteínas de unión estrecha puede utilizarse como un indicador más fino de los efectos producidos por la infección de las células por parte de Giardia como mostró Humen (2009), ya que está directamente relacionada con la diminución de la TEER y la pérdida de función barrera generada por el parásito.

En las figuras 39 y 40 se muestra la distribución de ocludina y claudina-1 respectivamente en diferentes condiciones, destacándose la pérdida de la distribución normal de ambas al ser incubadas con trofozoitos de Giardia intestinalis durante $24 \mathrm{~h}$. 

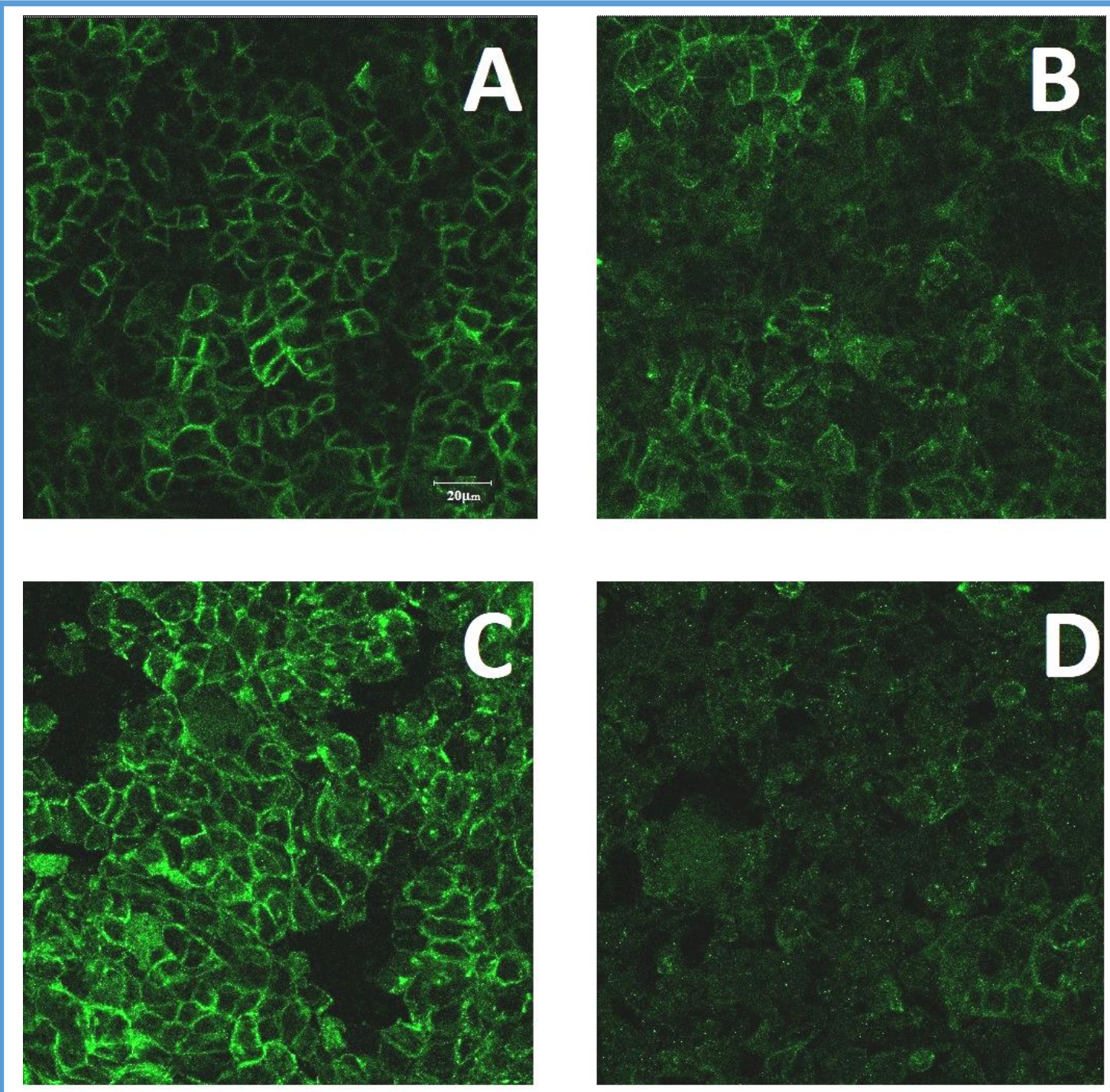

Figura 39: Distribución de ocludina por inmunofluorescencia indirecta en células Caco2/TC7. Proyección de las imágenes tomadas por microscopía confocal con un objetivo de inmersión Plan Apochromat 63X/1.40. (A) Control no infectado. (B) Células Caco-2/TC7 infectadas con Giardia intestinalis $\mathrm{H} 7(\mathrm{MDI}=2)$. (B) Células Caco-2/TC7 coincubadas con sobrenadante de kefir fresco neutralizado. (D) Células Caco-2/TC7 infectadas con Giardia intestinalis $\mathrm{H} 7(\mathrm{MDI}=2)$ y sobrenadante de kefir fresco neutralizado. Las imágenes son representativas de al menos tres ensayos independientes.

En los controles sin infectar se evidencia una estructura típica en forma de panal de abejas

(Figura 39 A y Figura 40 A) con una localización preferente de estas proteínas en los contactos célula-célula. Esta distribución se vuelve discontinua y se deslocaliza de las zonas de contacto célula-célula cuando la monocapa celular es infectada por trofozoitos de Giardia intestinalis (Figura 39 B y Figura 40 B). Con respecto a los ensayos en presencia de 
sobrenadante de kefir fresco, se observó una mayor pérdida de la distribución normal para claudina-1 (Figura 40 C), con una deslocalización importante de dicha proteína hacia el centro de las células. Para ocludina, en cambio, si bien se observa una deslocalización hacia otras zonas del citoplasma, la localización en los contactos célula-célula parece ser predominante (Figura $39 \mathrm{C}$ ).

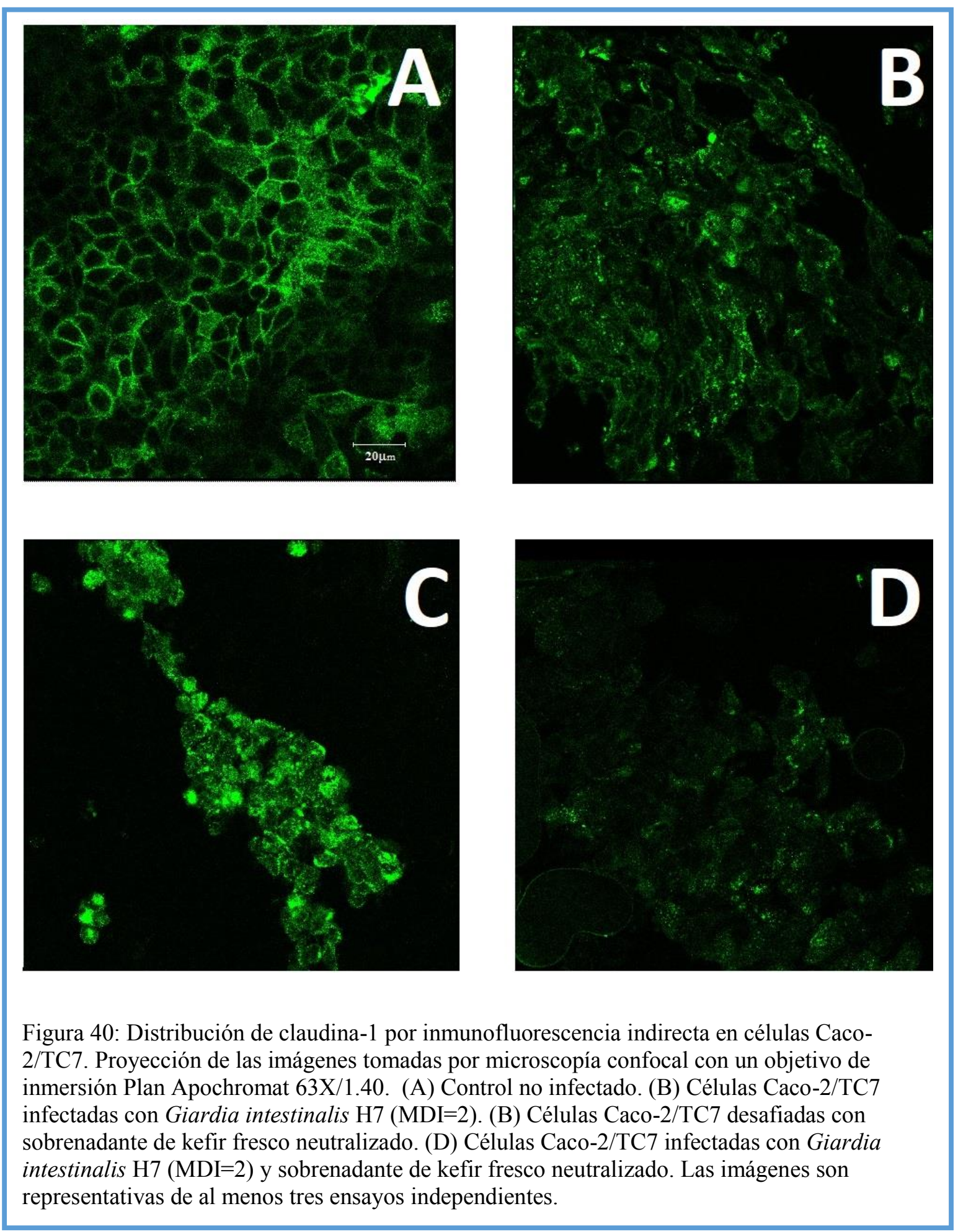


En cuanto a los ensayos con los trofozoitos de Giardia intestinalis y el sobrenadante de kefir fresco neutralizado, observamos para ambas proteínas una pérdida total de su distribución normal, distribuyéndose de un modo más o menos uniforme hacia el centro de las células (Figura 39 D y Figura 40 D).

Por otra parte, al tratar la monocapa celular con sobrenadante de kefir elaborado en permeado de suero al $20 \%$ (esterilizado por filtración y neutralizado) se observó un alto grado de desprendimiento de la monocapa celular. Esto parecería estar relacionado con la alta concentración de permeado utilizado, ya que el mismo fenómeno se observó con el permeado de suero al $20 \%$ sin fermentar (imágenes no mostradas).

A pesar de que la deslocalización de estas proteínas es útil como un indicador de la infección, el sistema resulta muy sensible para evaluar el efecto de un producto de composición compleja como los elaborados en este trabajo de tesis. Tanto las células en cultivo como los trofozoitos de Giardia son muy sensibles a la composición del medio y a las condiciones de crecimiento, y, como se puso de manifiesto al experimentar con el permeado de suero $20 \%$ (p/v) (fermentado o no), este sistema experimental mostró limitaciones para evaluar los efectos en presencia de todos los actores relevantes al sistema. Más aún, el estudio del efecto de microrganismos presentes en los productos desarrollados en este sistema experimental se vio totalmente imposibilitado debido a su actividad acidificante que es tiene un efecto adverso sobre los trofozoitos y las células. La imposibilidad de generar un sistema experimental en el cual se puedan involucrar los tres actores deseados: trofozoitos, células de epitelio intestinal y bacterias probióticas, llevó a la necesidad de experimentar en un modelo animal, en el cual se puedan observar otros indicadores que permitan establecer si la administración de un producto probiótico puede prevenir los efectos causados por la infección por parte de Giardia. 


\subsubsection{Ensayos in vivo}

\subsubsection{Recuento de trofozoitos en intestino delgado}

La presencia de trofozoitos viables en el intestino delgado es un indicio de una infección por Giardia en curso (Singer y col., 2000), incluso cuando la infección es transitoria. Los resultados de los recuentos de trofozoitos viables en intestino delgado muestran que la administración del probiótico en la condiciones ensayadas logró disminuir de un modo significativo $(\mathrm{p}<0.05)$ la intensidad de infección tanto a los 3 como a los 7 días post infección, respecto al grupo al cual no se le administró el probiotico. (Figuras 41 y 42).

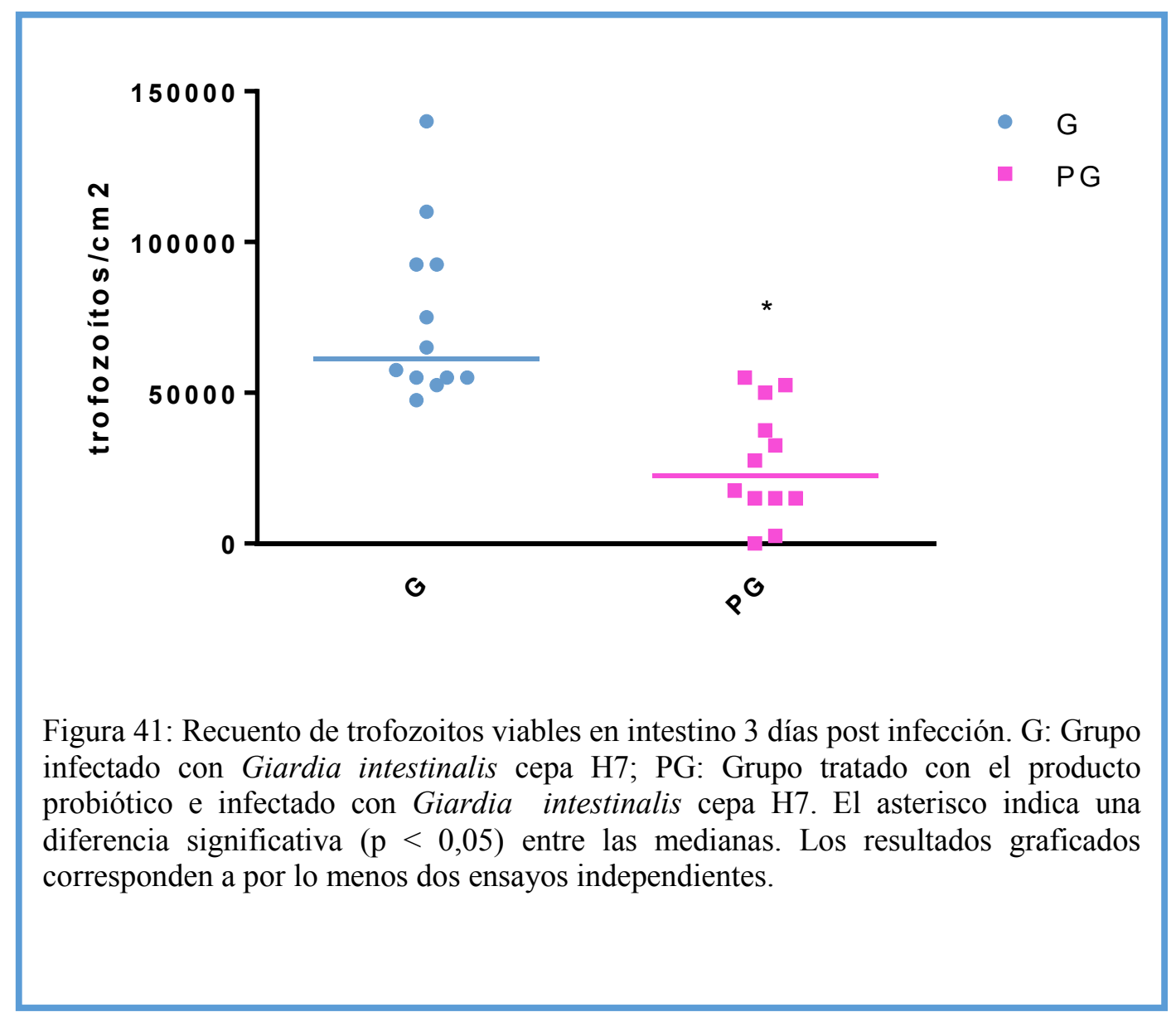

Varios autores han reportado una disminución en la intensidad de infección de Giardia invivo. Benyacoub y col. (2005) encontraron que la administración de un probiótico (Enterococcus faecium SF68) es capaz de atenuar la infección por Giardia en ratones C57BL/6. Shulka y col. (2008) reportaron una disminución de la intensidad de la infección 
por Giardia y una resolución de dicha infección tras 14 días mediante la administración de la cepa probiótica Lactobacillus casei. Más aún, nuestros resultados concuerdan con los reportado para kefir (Correa Franco, 2013) y con un producto probiótico compuesto por tres cepas aisladas de kefir entre las que se incluye L. plantarum CIDCA 83114 (Humen ,2009). Cabe destacar que Humen (2009) no observó un efecto antagónico frente a Giardia por parte de otras cepas probióticas (L. acidophilus); lo que sugiere que el efecto antagónico no es una propiedad general de los lactobacilos.

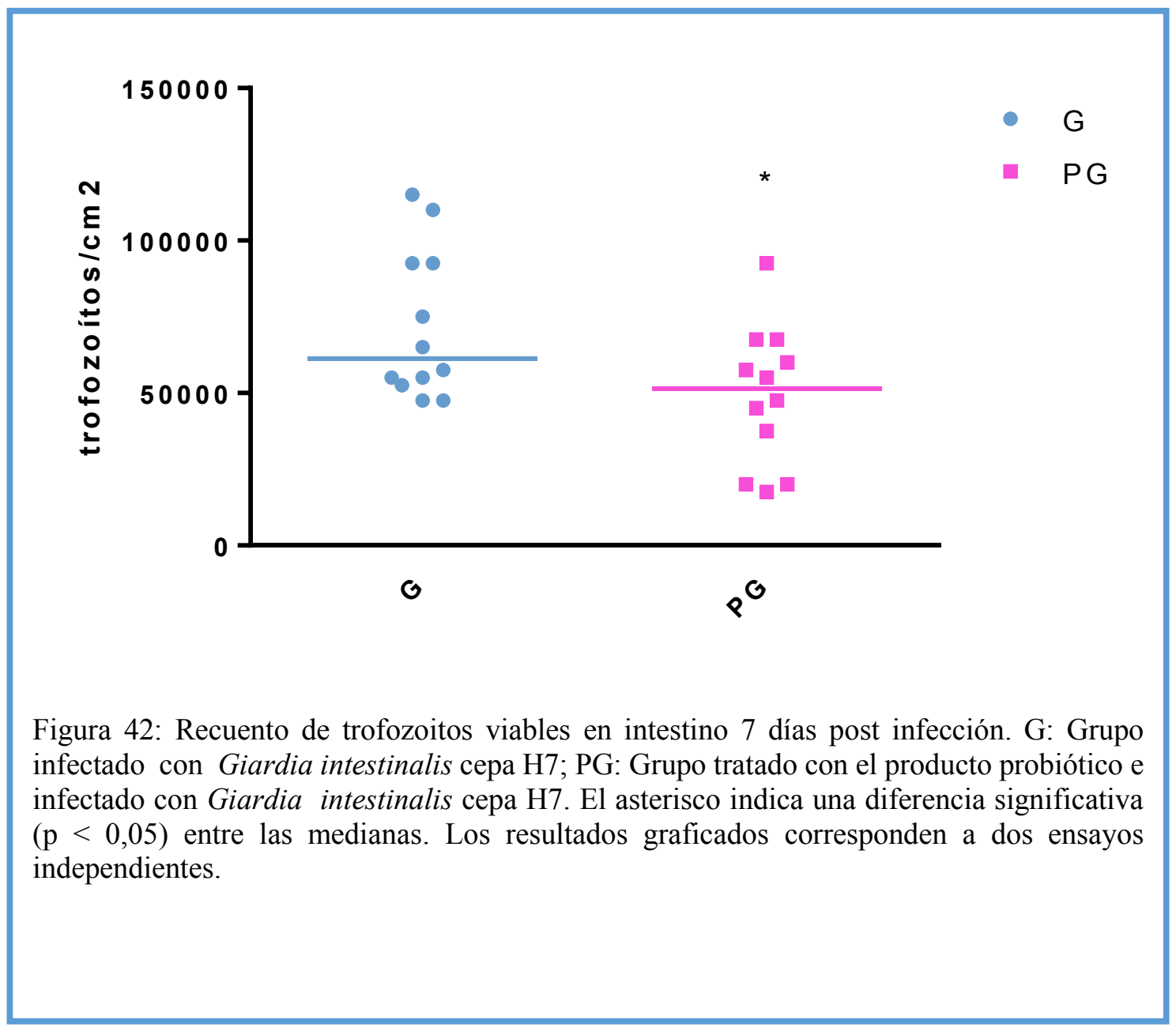

Así, este resultado no sólo da indicios de un efecto antagónico por parte de la cepa utilizada, si no que demuestra que la administración del probiótico deshidratado suspendido en agua de bebida mantiene las propiedades inhibitorias disminuyendo la intensidad de la infección. 


\subsubsection{Análisis histológico}

Los estudios en humanos y modelos animales han demostrado que los trofozoitos de Giardia no invaden el tejido intestinal, y la fisiopatología de la giardiasis sólo incluye ocasionalmente un aumento de linfocitos intraepiteliales y la atrofia parcial de las vellosidades intestinales (Cotton y col., 2011). Pese a que la infección por parte de este G. intestinalis en modelo murino tiene un carácter transitorio, se ha demostrado en varias investigaciones para evidenciar el acortamiento de las vellosidades intestinales y la perdida funcionalidad del epitelio intestinal (Shukla y Sidhu, 2011; Solaymani-Mohammadi y col, 2011).

En las micrografías de cortes histológicos de intestino (Figura 43) podemos ver para el grupo G (Figura 43, D), y comparándolo con el control (Figura 43, A), un acortamiento de las vellosidades intestinales, aunque no se evidencian signos notables de inflamación. Por su parte, la administración del probiótico (como se observa para el grupo P en la Figura 43, B) no generó daño o acortamiento de las vellosidades. Para el caso del grupo PG (Figura 43, C) se evidencia un acortamiento de las vellosidades intestinales, pero en menor número que para el grupo $\mathrm{G}$, indicando que la administración del producto probiótico disminuye el daño a las vellosidades intestinales causado por la infección del parásito. 

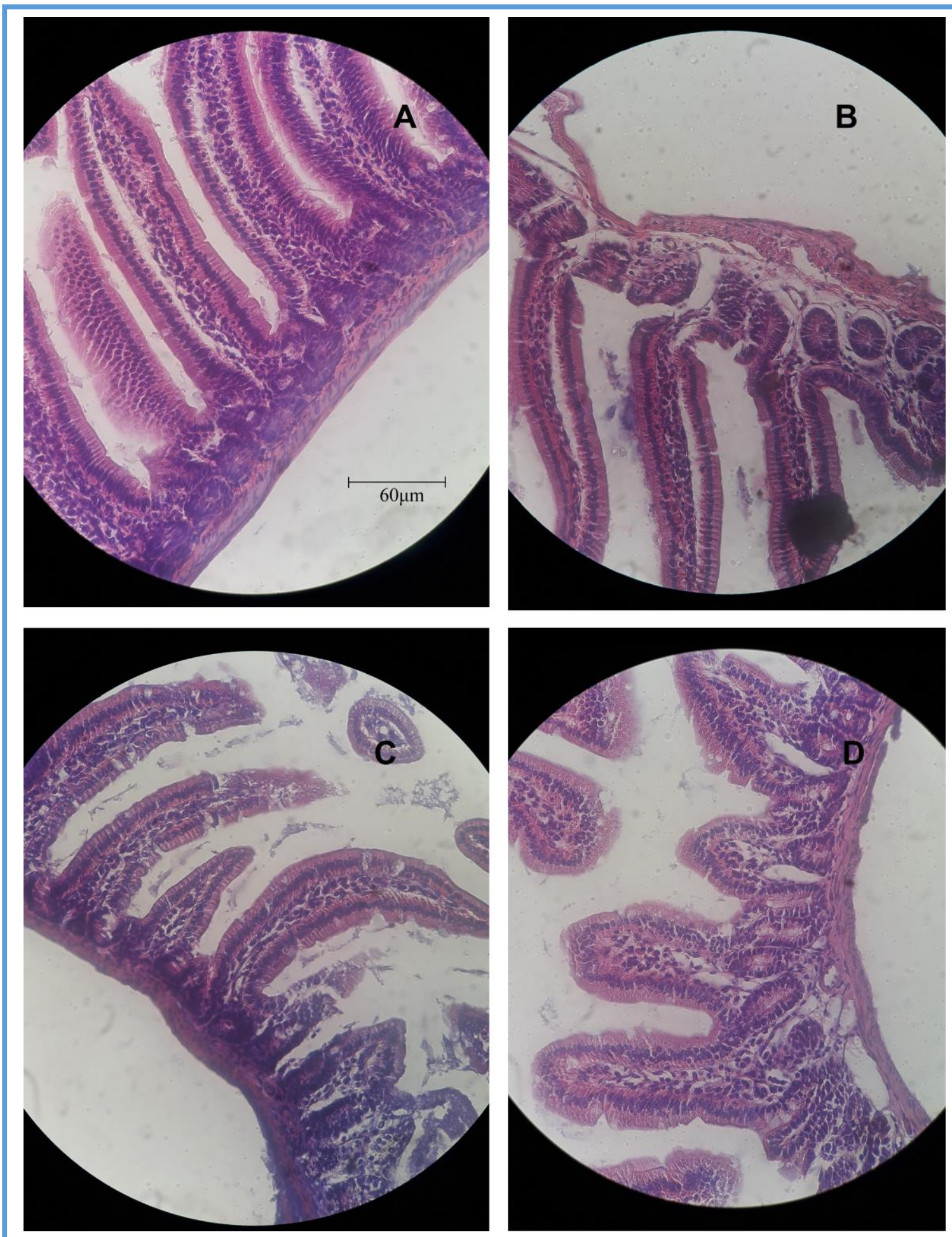

Figura 43: Coloración hematoxilina-eosina para cortes histológicos de intestino. Cada imagen es representativa de uno de los grupos definidos para los ensayos in-vivo: A) Grupo C: grupo control sin tratamiento; B) Grupo P: grupo que consumió sólo el producto probiótico; C) Grupo PG: Grupo tratado con el producto probiótico e infectado con Giardia intestinalis cepa H7; y D) Grupo G: Grupo infectado con Giardia intestinalis cepa H7. El aumento en todos los casos es de 40X. 


\subsubsection{Análisis de poblaciones celulares en medula ósea}

Los mastocitos son reconocidos como células efectoras de la respuesta inmune contra varios parásitos. Si bien los mecanismos de respuesta inmune del hospedador frente a la infección por parte de Giardia no se encuentran totalmente dilucidados, varios autores han reportado que existe un rol importante por parte de los mastocitos y sus productos en el control de dicha infección. (Li y col, 2004, López-Romero y col. 2015). En este sentido, antecedentes de nuestro grupo de investigación demostraron que existía un incremento en el número de mastocitos en bazo de hembras de ratón infectadas con Giardia, y que, además, este incremento no era observado cuando los animales consumían un probiótico antes y durante el transcurso de la infección por parte del parásito (Humen, 2009). Dado que el bazo es un órgano hematopoyético en ratón, estos hallazgos sugieren un incremento de las células hematopoyéticas comprometidas en el linaje mieloide. Siguiendo este razonamiento, y basados en los trabajos de Salva y col., (2012 y 2014), se decidió realizar una evaluación mediante citometría de flujo de las diferentes poblaciones hematopoyéticas en medula ósea, que es el órgano hematopoyético por excelencia.

Las citometrías realizadas para identificar las diferentes poblaciones hematopoyéticas presentes en la medula ósea de los ratones no mostraron diferencias significativas entre los diversos tratamientos y el control (Figura 44). Posiblemente, debido al carácter transitorio de la infección en el modelo murino escogido y una cuestión de localización anatómica el incremento en el número de mastocitos observado en bazo por Humen (2009) no pudo reflejarse en el análisis de poblaciones celulares de medula ósea. Tampoco se hallaron diferencias en las distintas subpoblaciones celulares del linaje linfoide maduro (Figura 45).

Además, si bien este método ha permitido establecer que una cepa probiótica de $L$. rhamnosus promueve la mielopoyesis en ratones (Salva y col., 2014), es necesario destacar que los efectos fueron observados en modelos experimentales muy diferentes al empleado 
en el presente trabajo de tesis ya que se utilizaron ratones inmunocomprometidos o desnutridos. En las condiciones del presente trabajo de tesis, los estímulos empleados son de carácter mucho más moderado, pudiendo ser esta la razón por la cual no se observó un cambio significativo de alguna población hematopoyética en particular.

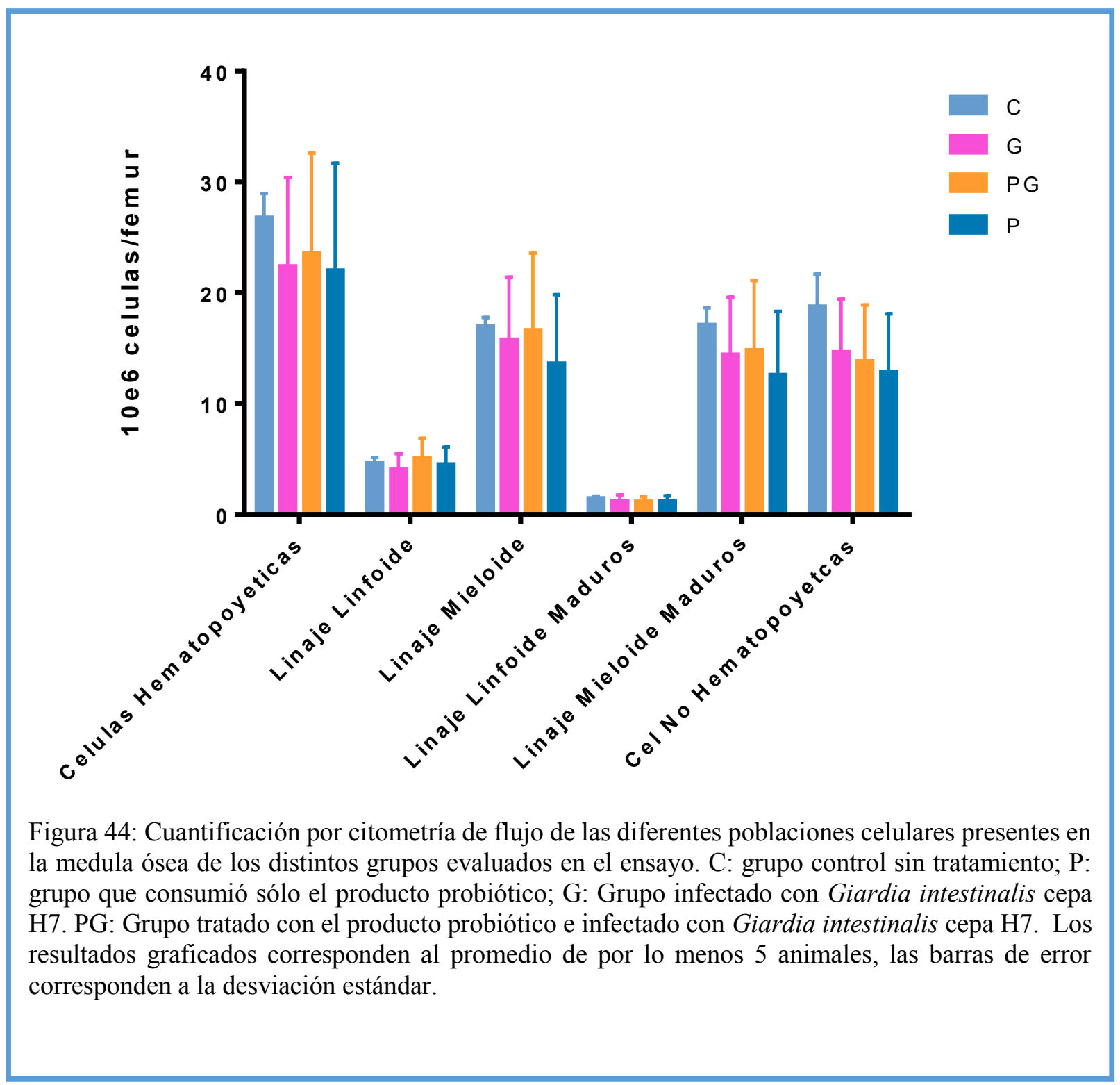




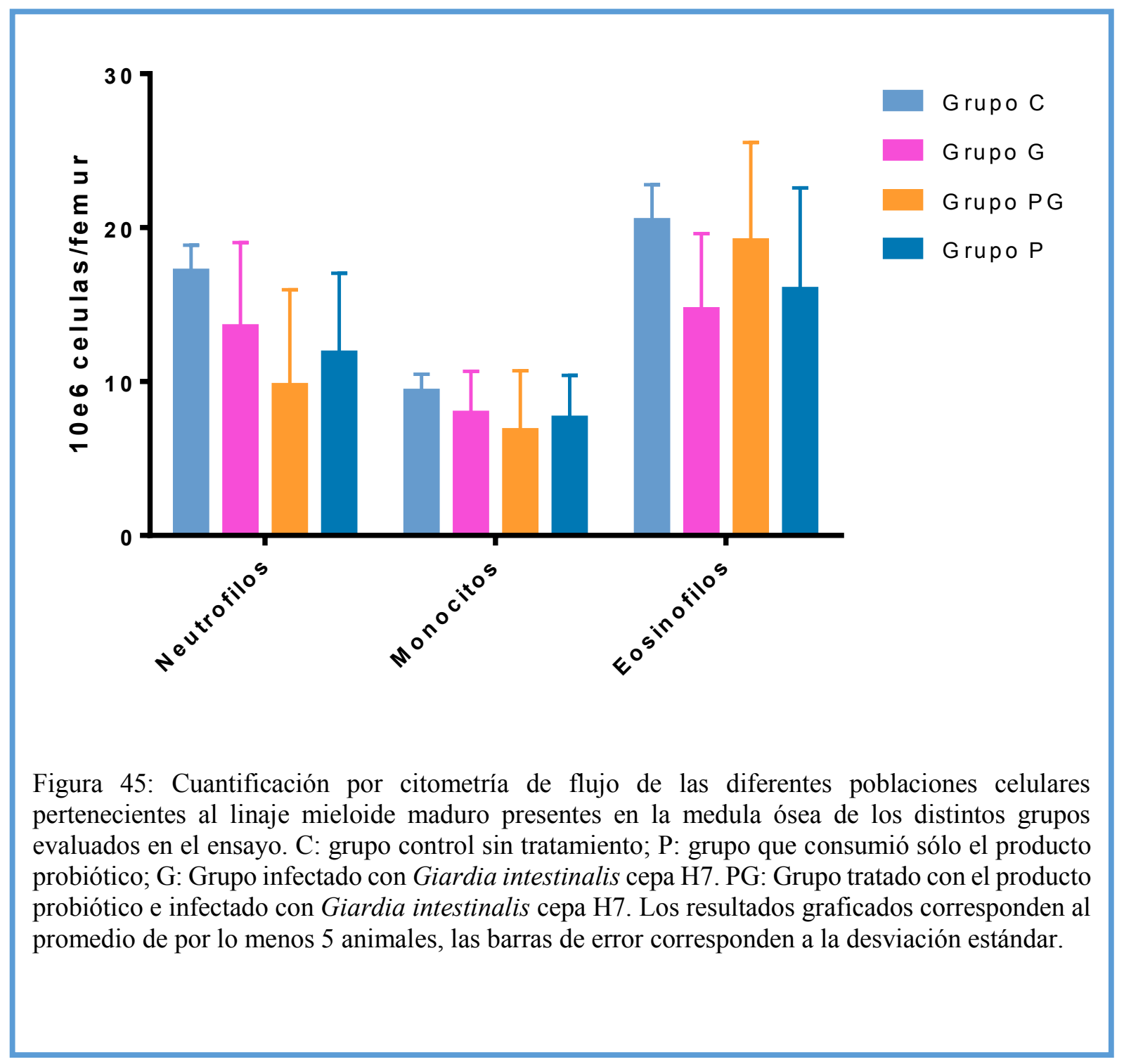

\subsubsection{Análisis de la expresión de citoquinas en placas de Peyer}

El epitelio intestinal posee un rol fundamental en el mantenimiento de la homeostasis inmune en el intestino, no sólo actuando como una barrera entre el contenido luminal intestinal, si no también actuando como mediador con células inmunes subyacentes. Además, en un actor activo en el mantenimiento la microbiota y la relación de ésta con el huésped. Sin embargo, la barrera epitelial intestinal no impide completamente que diversas moléculas y/o estructuras presentes en el contenido luminal y capaces de desencadenar una respuesta inmune ingresen en los tejidos. Estos estímulos pueden penetrar en la mucosa intestinal y 
alcanzar el tejido linfoide asociado con el intestino (GALT, del inglés: Gut-associated lymphoid tissue) a través de distintas vías. Si bien los antígenos pueden ingresar a través de los enterocitos, la entrada a través de células M presentes en las placas de Peyer constituye una vía altamente relevante. Las células $\mathrm{M}$ captan antígenos luminales lo cual facilita el contacto con las CPA (células presentadoras de antígenos) que internalizan y procesan los antígenos para presentar regiones peptídicas de éstos en la membrana plasmática asociados a moléculas del complejo mayor de histocompatibilidad (MHC). Este conjunto (péptidoMHC) es reconocido por el receptor de células T (TCR). Las CPA activadas pueden interaccionar con linfocitos $\mathrm{T}$ colaboradores (Th) de las áreas interfoliculares de la placa de Peyer o migrar hacia los ganglios linfáticos mesentéricos a través de vasos linfáticos.

Una vez activados, los linfocitos Th pueden diferenciarse principalmente en diferentes subpoblaciones efectoras denominadas Th1, Th2 y Th17, con diferente funcionalidad y que generan un perfil de citoquinas específico.

Los linfocitos Th1 se caracterizan por la secreción de interferón $\gamma$ (IFN $\gamma)$, interleuquina 2 (IL-2) y linfotoxina (LT o TNF- $\beta$ ) y su función principal es la defensa mediada por fagocitos contra infecciones, especialmente frente a microorganismos intracelulares (virus, bacterias y algunos protozoos). Por otra parte, los linfocitos Th2 productores de IL-4, IL-5 e IL-13 actúan como mediadores de reacciones alérgicas y en la defensa frente a infecciones producidas por patógenos extracelulares. La tercera subpoblación efectora, Th17, caracterizada por la secreción de IL-17 e IL-6, parece estar implicada en la defensa frente a infecciones bacterianas y fúngicas no cubiertas totalmente por los perfiles de respuesta Th1 y Th2 (Harrington y col., 2005; Park y col., 2005).

Además de estas tres subpoblaciones efectoras, está establecida la presencia de linfocitos T reguladores: linfocitos Treg productores principalmente de IL-10 y linfocitos Th3 
caracterizados por la secreción de factor de transformación del crecimiento $\beta$ (TGF- $\beta$, del inglés: Transforming Growth Factor). Estos linfocitos son especialmente importantes en el intestino por su capacidad regulatoria de la respuesta inmunitaria durante procesos inflamatorios e infecciosos. Además desempeñan un papel clave en el desarrollo de la tolerancia oral frente antígenos inocuos procedentes de la dieta y de la microbiota comensal, entendiéndose por tolerancia oral la modulación de la respuesta inmunitaria sistémica frente a un antígeno, al cual un individuo ha estado previamente expuesto a través del tracto gastrointestinal.

En la giardiasis, la mayoría de las interleuquinas son producidas por linfocitos CD4 + de las placas de Peyer o generadas a partir del GALT como resultado de la estimulación antigénica a través de la etapa quística de G. intestinalis (Scott, y col., 2004). El tipo y la cantidad de estas respuestas de citoquinas pueden verse afectadas por el parásito infectante, ya sea invasivo o no invasivo (Jung, y col., 1995). Por este motivo el análisis de la expresión de citoquinas en placas de Peyer puede dar un indicio de las vías inmunitarias que son activadas por el parásito y si la administración del producto probiótico ejerce modificaciones en los niveles de expresión lo cual podrías estar relacionado con los mecanismos que expliquen el potencial efecto benéfico de los probióticos en el contexto de una infección con Giardia.

La habilidad del huésped para erradicar efectivamente un organismo invasor depende de la respuesta inmune efectora ejecutada. Tal como se explicó, las células Th1 son más adecuadas para proteger contra parásitos intracelulares mientras que los parásitos extracelulares son mejor controlados por un perfil mixto Th2 y Th1 (Annunziato y col., 2015; Romagnani, 1997). La reacción óptima contra parásitos extracelulares es dada por células Th2, las cuales también inhiben el desarrollo de células Th1 y actividad de macrófagos, evitando así la tentativa de destruir grandes parásitos a través de la respuesta Th1 y de macrófagos, la cual puede ser dañina para el huésped (Allen y col., 2014; Finkelman y col., 1997). 
En la Figura 46 se muestran las expresiones relativas de IL-10 (A) e IL-12 (B) para los distintos grupos experimentales.

A

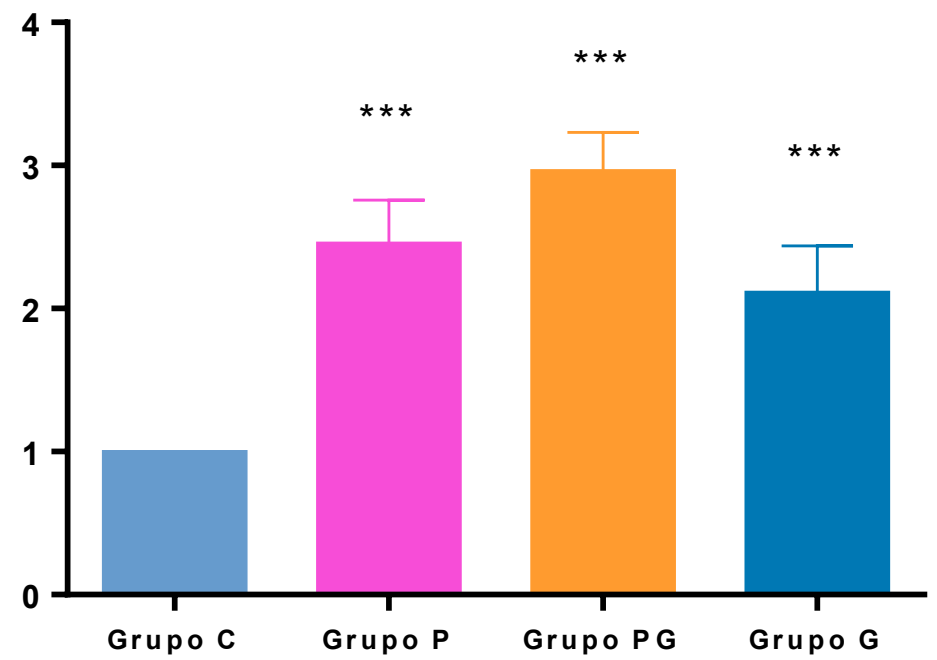

B

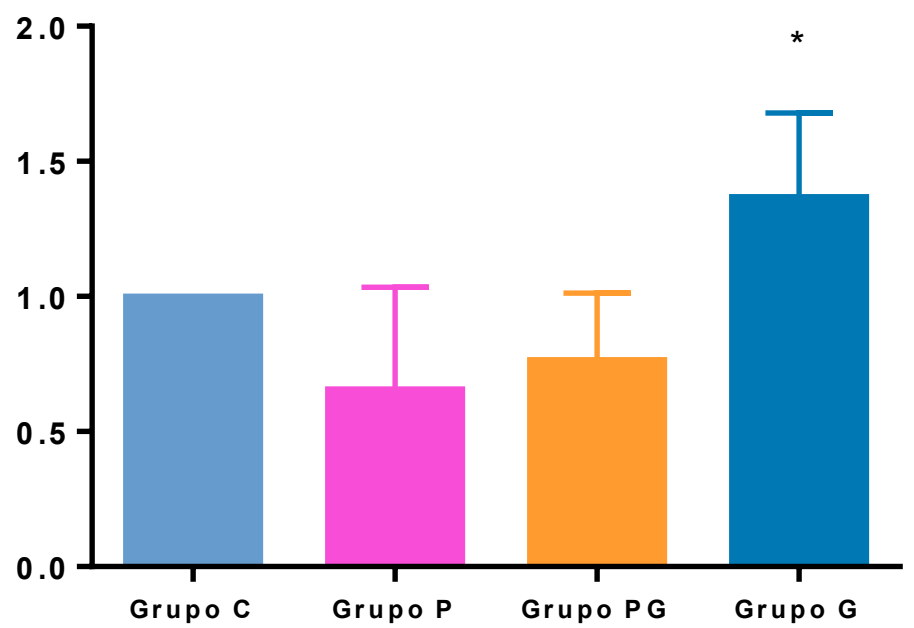

Figura 46: Expresión Relativa de IL-10 (A) e IL-12 (B) con respecto al grupo control en los diferentes grupos experimentales. C: grupo control sin tratamiento; $\mathrm{P}$ : grupo que consumió sólo la cepa probiótica; G: Grupo infectado con Giardia intestinalis cepa H7. PG: Grupo tratado con la cepa probiótica e infectado con Giardia intestinalis cepa H7. Los resultados graficados corresponden al promedio de todos los animales dentro del grupo experimental, mientras que la barra de error corresponde a la desviación estándar entre las medidas. Los asteriscos indican diferencias estadísticamente significativas: $\mathrm{p}<0,1=*$; $\mathrm{p}<0,05=* *$ y $\mathrm{p}<0,01=* * *$. 
Como se puede observar en la Figura 46, el tratamiento con la cepa probiótica estimula significativamente la producción de la citoquina anti-inflamatoria IL-10 con respecto al grupo control y disminuye la expresión de IL-12. La infección con el parásito, también estimula la producción de IL-10, pero en menor medida que la administración del probiótico. Además, a diferencia de los grupos tratados con probiótico, Giardia aumenta la producción de IL-12. El aumento de IL-12 producido por Giardia no se observa en el grupo PG, lo que es compatible con un efecto inmunomodulador del probiótico.

Este efecto, se visualizó mejor al evaluar la relación IL-10/IL-12 para cada grupo (Figura 47).

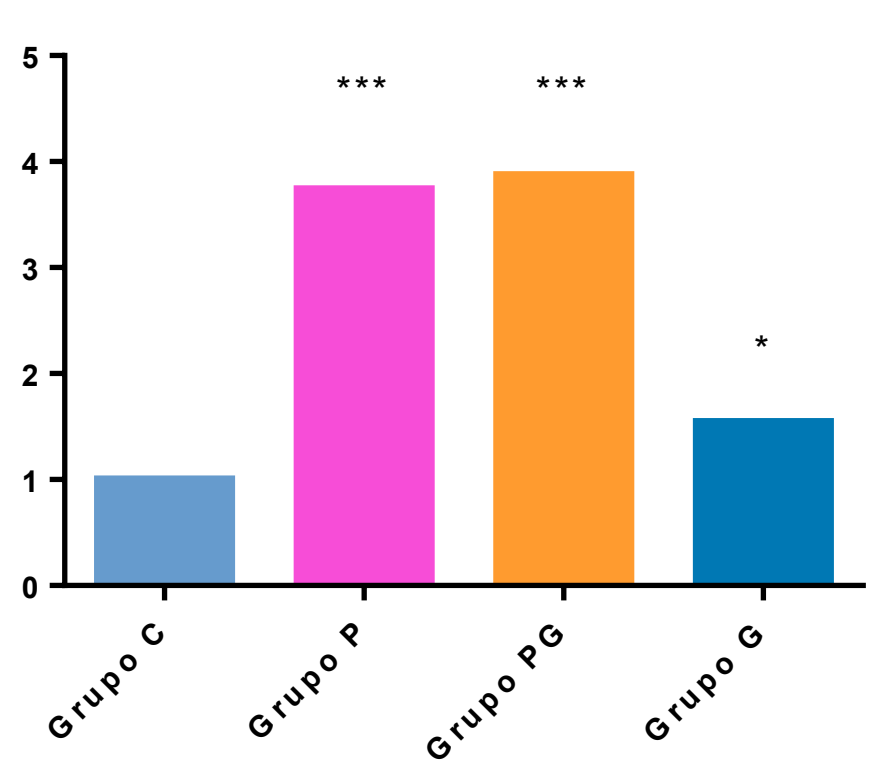

Figura 47: Relación IL-10/IL-12 para los distintos grupos experimentales. C: grupo control sin tratamiento; P: grupo que consumió sólo la cepa probiótica; G: Grupo infectado con Giardia intestinalis cepa H7. PG: Grupo tratado con la cepa probiótica e infectado con Giardia intestinalis cepa H7. Los asteriscos indican diferencias estadísticamente significativas: $\mathrm{p}<0,1=* ; \mathrm{p}<0,05=* *$ y $\mathrm{p}<0,01=* * *$. 
Si bien se observó que existe un efecto inmunomodulador por parte de Giardia (grupo G), este fue sustancialmete inferior comparado con el grupo PG, cuyo efecto inmunomodulador fue similar al observado para el grupo P. La administración del probiótico parece estimular una respuesta Th2 (que sería adecuada frente a la infección por un parásito extracelular), mientras que el grupo sólo infectado con Giardia (grupo G) aumentó la producción de IL12 evitando este tipo de respuesta.

Uno de los efectos principales de IL12 es aumentar la producción de IFN- $\gamma$, el cual dirige el perfil de diferenciación de los linfocitos T CD4+ hacia Th1. Sin embargo, para el grupo G observamos una fuerte inducción en la expresión de IL12, pero que no se correlaciona con un alto nivel de IFN- $\gamma$ (Figura 50). Singer y Nash (2000) observaron una eliminación normal del parásito en ratones deficientes en IFN- $\gamma$, lo que indicaría que tanto Th1 como Th2 no son absolutamente necesarias para la resolución de la infección, o, que la respuesta inmune frente a la invasión por Giardia utiliza una vía diferente. Esta última hipótesis ha cobrado fuerza desde los reportes de Saghaug y col. (2016) que observaron un aumento importante de la expresión de IL-17 en individuos infectados por el parásito, lo que sugiere que la vía Th17 cumple un rol destacado para la eliminación de Giardia del organismo.

Como se muestra en la Figura 48, la expresión de TNF- $\alpha$ fue significativamente mayor en los ratones infectados con el parásito. Esto concuerda con las afirmaciones de Grit y col. (2014), que establecen que TNF- $\alpha$ es otra citoquina proinflamatoria liberada durante la infección por Giardia. La administración del probiótico también generó un aumento significativo de los niveles de expresión de TNF- $\alpha$, el cual pudo ser un efecto inmunomodulador directo del probiótico administrado o estar relacionado con los cambios generados por el mismo en la composición de la microbiota que pueden desencadenar repuestas inmunes en el hospedador (ver más adelante, sección 2.4.2.5). 
A

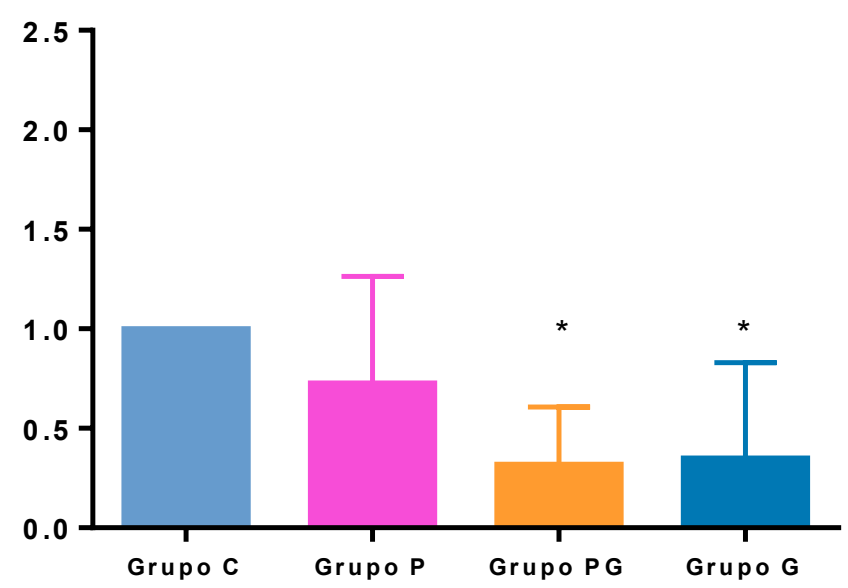

B

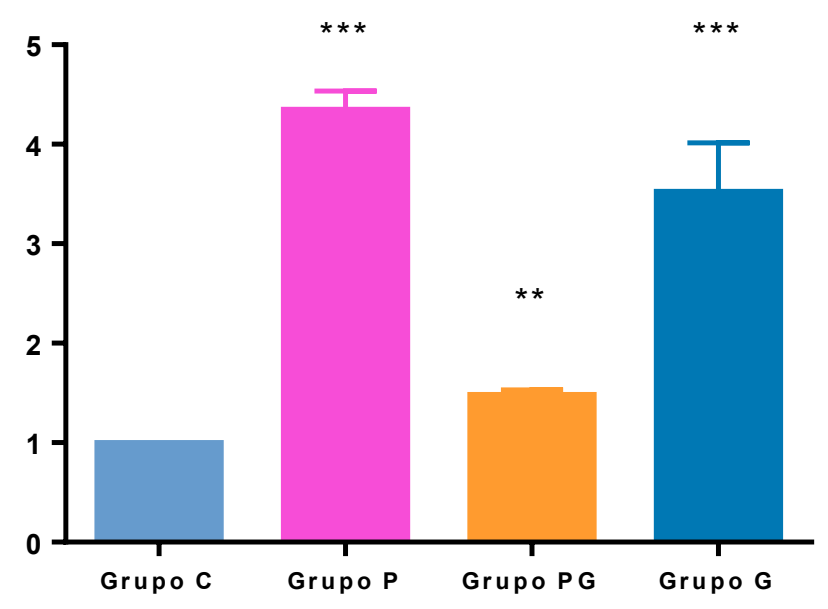

Figura 48: Expresión Relativa de INF- $\gamma$ (A) e TNF- $\alpha$ (B) con respecto al grupo control. C: grupo control sin tratamiento; P: grupo que consumió sólo la cepa probiótica; G: Grupo infectado con Giardia intestinalis cepa H7. PG: Grupo tratado con la cepa probiótica e infectado con Giardia intestinalis cepa H7. Los resultados graficados corresponden al promedio de todos los animales dentro del grupo experimental, mientras que la barra de error corresponde a la desviación estándar entre las medidas. Los asteriscos indican diferencias estadísticamente significativas: $\mathrm{p}<0,1=* ; \mathrm{p}<0,05=* *$ y $\mathrm{p}<0,01=* * *$.

Por su parte, la administración del probiótico antes y durante la infección con el parásito

(Grupo PG) moderó este aumento en la expresión de TNF- $\alpha$, sugiriendo una disminución en la respuesta generada por el parásito. Si bien existen reportes acerca del rol de TNF- $\alpha$ en la 
giardiasis (Grit y col., 2014; Zhou y col., 2007), los mecanismos mediante los cuales TNF$\alpha$ afecta a Giardia no se encuentran completamente dilucidados. Las observaciones ya comentadas respecto a la necesidad de una respuesta inmune de perfil mixto Th1 y Th2 para la eliminación del parasito y los reportes que informan acerca de una posible participación de la respuesta Th17, sugieren que la infección con Giardia desencadena una amplia gama de citoquinas que resulta en una respuesta integrada de la inmunidad innata con la adaptativa para la eliminación del parásito.

\subsubsection{Análisis de la microbiota fecal}

Los mecanismos por los cuales Giardia coloniza el tracto gastrointestinal e induce la enfermedad diarreica siguen sin dilucidarse completamente (Bartelt 2015). Giardia no produce toxinas, y la colonización por parte del parásito no induce una reacción inflamatoria robusta (Bartelt, 2015; Cotton y col., 2015). Se sabe que las infecciones por Giardia pueden conducir a síndromes posinfecciosos, que incluyen desnutrición, síndrome del intestino irritable (IBD, del inglés: Inflammatory Bowel Disease) y síndrome de fatiga crónica. Varios de estos síndromes se asocian con un desbalance en la microbiota intestinal, y se sabe que las comunidades microbianas intestinales tienen un rol fundamental en la colonización por parte de patógenos.

Existe evidencia de que las interacciones entre Giardia y estos microbios comensales podrían contribuir a las variaciones en la patogénesis y los síntomas adversos asociados con la giardiasis (Eckmann L., 2003; Singer ,2000). Esta idea está respaldada por la evidencia de una relación directa entre la infección por Giardia y el sobrecrecimiento bacteriano intestinal (Müller y von Allmen, 2005.). La infección por Giardia, además, causa una mayor traslocación bacteriana una vez que ésta se resuelve como secuela de la interrupción de la barrera intestinal. 
Junto con los efectos directos sobre los tejidos del huésped, Giardia podría causar alteraciones en la microbiota intestinal, al alterar la composición microbiana, las capacidades metabólicas o la homeostasis química en la luz del tracto digestivo. En este sentido, se ha demostrado que en modelo merión, Giardia causa un deterioro de la estructura epitelial del intestino muy similar al observado en la enteritis bacteriana y enfermedad de Crohn (Buret y col. 1992; Humen y col., 2005), dos patologías asociadas a desbalances en la microbiota intestinal. Otras enfermedades intestinales asociadas a desbalances de la microbiota intestinal incluyen enfermedades infecciosas con patógenos bacterianos conocidos (Ej., Clostridium difficile o Salmonella enterica serovar Typhimurium) y enfermedades inmunomediadas en las que la totalidad de la comunidad intestinal parece perturbada en ausencia de una especie patógena dominante (Ej., enfermedad de Crohn y enfermedad del intestino irritable [IBS: del inglés: Irritable bowel syndrome]) (Faber y col., 2014; Hold y col. 2014; Torres y col. 2000; Weingarden y col. 2015).

Barash y col. (2017) demostraron que la colonización por Giardia del intestino delgado en ratones causa una disbiosis que persiste durante la infección. Esta disbiosis puede estar mediada directamente a través del metabolismo anaeróbico único del parásito $\mathrm{y} / \mathrm{o}$ indirectamente a través de la inducción del parásito de las respuestas del huésped. Esta alteración sistémica de la ecología intestinal murina también podría explicar la variación observada en la giardiasis con respecto a la patología del huésped, el grado de colonización del parásito, el inicio de la infección y su eventual eliminación.

Así, resulta de gran interés evaluar las modificaciones producidas en la microbiota por parte del parásito, y como ésta se ve modificada o no mediante la administración del probiótico. 


\subsection{Análisis por DGGE}

Se amplificó una región del gen que codifica para el ARNr 16S bacteriano en todas las muestras de ADN provenientes de las heces de los ratones de los experimentos in-vivo para evaluar por DGGE la composición de la microbiota en los animales sometidos a distintos tratamientos

A modo de ejemplo se muestra en la Figura 49 uno de los geles de DGGE obtenidos durante el presente trabajo. En dicha figura podemos observar la presencia de bandas distintivas para el grupo PG (calles 1,2 y3), que no se evidencian en las calles para los grupos infectado con Giardia (calles 4 a 7) o control (calles 8 y9). También, se observa para el grupo control (Calles 8 y 9) la ausencia de una banda que aparece en los otros grupos y la presencia de otra banda que sólo se evidencia en el grupo control.

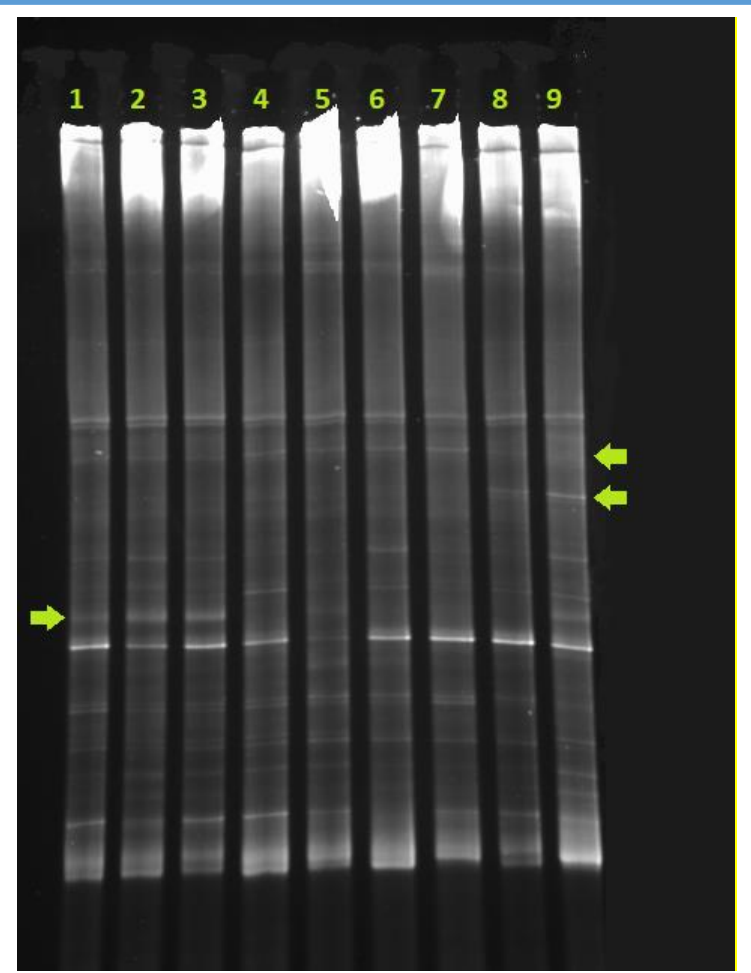

Figura 49: Fotografia de un gel de DGGE. Calles 1 a 3 Grupo PG (grupo tratado con la cepa probiótica e infectado con Giardia intestinalis cepa H7); Calles 4 a 7 Grupo G (grupo infectado con Giardia intestinalis cepa H7) y Calles 8 y 9 grupo C (grupo control sin tratamiento). Con flechas verdes se destacan bandas de interés para el análisis. 
El dendrograma obtenido a partir del análisis de las bandas presentes en los geles de DGGE muestra una separación clara en 4 grupos, coincidentes con los grupos que se definieron en el esquema experimental (Figura 50). Este hallazgo resulta de suma importancia porque indica que los cambios de la microbiota producidos en las diferentes condiciones, pueden ser detectados mediante estudios de DGGE y alientan a realizar técnicas más refinadas que permitan indagar con más detalle las modificaciones producidas.

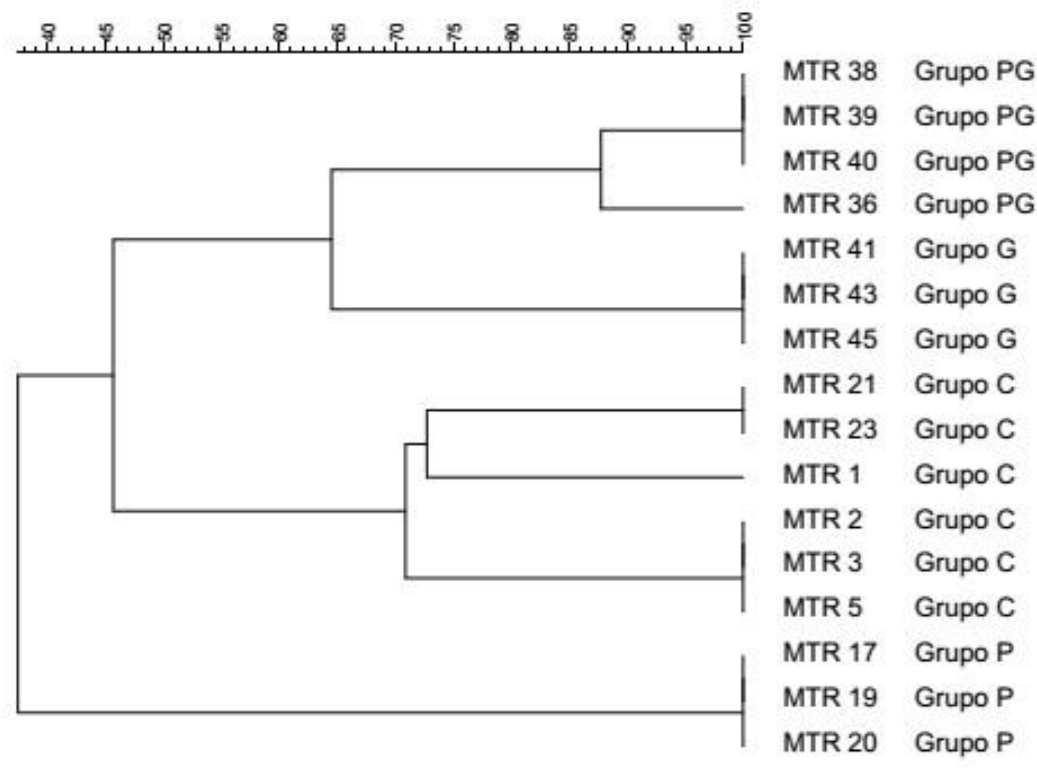

Figura 50: Dendrograma para la DGGE de los perfiles bacterianos totales. El análisis de agrupamiento se realizó utilizando el enlace UPGMA. C: grupo control sin tratamiento; P: grupo que consumió sólo la cepa probiótica; G: Grupo infectado con Giardia intestinalis cepa H7. PG: Grupo tratado con la cepa probiótica e infectado con Giardia intestinalis cepa H7.

\subsection{Análisis por secuenciación}

La existencia de grupos tan definidos en los ensayos de DGGE condujo a la realización de un análisis por secuenciación para establecer la abundancia relativa de las distintas 
subpoblaciones bacterianas presentes en los diferentes grupos experimentales. Estos resultados se muestran en la Figura 51.

La administración del producto deshidratado elaborado a base de la cepa probiótica condujo a un aumento de Lactobacillaceae muy importante, representando un $25 \%$ del total de las diferentes familias bacterianas identificadas en el grupo que recibió el tratamiento con el probiótico (Figura 51, B). El grupo que recibió el probiótico y además fue infectado con Giardia (Figura 51, C), también mostró una cantidad elevada de Lactobacillaceae respecto al control, representando casi un $10 \%$ de la microbiota residente. Este resultado indica que cepa probiótica administrada generó un cambio de la composición de la microbiota intestinal. Es muy probable que el aumento de la subpoblación de lactobacilos esté asociado a la presencia de la bacteria administrada pero no puede descartarse el efecto sobre la abundancia de otros lactobacilos.

En este sentido, existen trabajos con otras cepas probióticas aisladas de kefir que muestran un incremento significativo en la cantidad de Lactobacillus spp.cultivables en muestras fecales de ratones tratados durante 21 días con probiótico (Carasi y col., 2015).

Resulta interesante observar como la infección con el parásito modifica la abundancia relativa de ciertas especies. Barash y col. (2017), reportaron que la giardiasis perturba la diversidad y abundancia de las comunidades microbianas comensales del huésped. Esta alteración de la ecología intestinal comensal murina durante la giardiasis probablemente contribuye al inicio de la infección, el grado de colonización, la inducción de la patología en el huésped y / o la eliminación eventual del parásito (Singer y Nash, 2000; Eckmann, 2003). En general, los phyla Firmicutes y Bacteroidetes dominan la comunidad intestinal microbiana, representando más del $90 \%$ de la abundancia relativa de microbios intestinales tanto en humanos como en ratones (Arumugam y col. 2011; Nguyen y col., 2015), mientras 
que los miembros de Proteobacteria, Actinobacteria, Verrucomicrobia son phyla menos abundantes.

El phylum Bacteroidetes se compone de bacterias anaerobias Gram negativas, no formadoras de esporas, que toleran la presencia de oxígeno pero no pueden usarlo para el crecimiento (como Bacteroides fragilis). Los Firmicutes, por su parte, son un phylum diverso compuesto principalmente por 2 clases: Bacilli y Clostridia. Incluye microrganismos Gram-positivos, anaeróbicos (Clostridia) y aerobios obligados o facultativos (Bacilli) caracterizados por un bajo contenido de GC. Los lactobacilos, como el L. plantarum que fue administrado a los animales durante el ensayo, se incluye dentro de la clase Bacilli. Las Actinobacterias, por ejemplo Bifidobacterium, son bacilos ramificados, Gram-positivos, no móviles, no formadoras de esporas y anaerobios, Mientras que las Proteobacterias (p. Ej., Escherichia, Klebsiella, Enterobacter) son anaerobios aeróbicos o facultativos, Gramnegativos, no formadores de esporas, que habitan en el tracto intestinal de todos los vertebrados (Belizário y Napolitano2015).

Como se puede observar en la Figura 51, la infección por parte del parásito genera un desbalance en la microbiota en el cual disminuye la proporción de Bacteroidetes y aumenta la proporción de Firmicutes, sobre todo de los Clostridiales. Además, también se observa un aumento en la proporción de alfa proteobacteria y de las Verrucomicrobia (pertenecientes al superphylum Planctobaterias -PVC-) en el grupo de animales infectados por Giardia.

Como se explicó anteriormente, varios autores han asociado el desbalance de la microbiota intestinal en una o varias especies bacterianas con patologías del tracto gastrointestinal. Por ejemplo, la enfermedad inflamatoria intestinal (IBD), cuyas principales manifestaciones clínicas son la enfermedad de Crohn y la colitis ulcerosa, se asocia con una disminución de Firmicutes y Bacteroidetes, y un aumento en Proteobacteria y Actinobacteria, en particular, las familias Pasteurellaceae, Veillonellaceae, Fusobacteriaceae, Enterobacteriaceae y 
algunas cepas invasivas de E.coli. En las muestras fecales de pacientes con IBD disminuyeron Bifidobacterium, Lactobacillus, Bacteroidetes y Actinobacteria y aumentaron Enterobacteriaceae y Proteobacteria. Esto coincide con los hallazgos de Shin y col. (2015) quienes reportaron que un incremento de Proteobacteria en el intestino refleja disbiosis o una estructura de la comunidad microbiana intestinal inestable. Además de las proteobacterias enteropatógenas exógenas que podrían ingresar al tracto digestivo, el intestino sano de los mamíferos contiene varios miembros de este phylum como parte de su microbiota natural que, bajo ciertos ambientes intestinales, pueden convertirse en microbios colitogénicos que pueden desencadenar respuestas inflamatorias (Caporaso y col. 2011; Costello y col., 2009).

En el presente trabajo, el consumo del probiotico generó, además del incremento en la proporción de Lactobacillaceae, una importante disminución de la clase Clostridia y un aumento en el phylum Verrucomicrobia con respecto al control. Es importante mencionar que el phylum Verrucomicrobia (en particular Akkermansia muciniphila) parece estar relacionado en el mantenimiento de las funciones de barrera intestinal mediante su acción moduladora en la mucosa (Derrien y col., 2011).

Finalmente, al analizar el grupo PG, se observó un aumento en la abundancia de Lactobacillaceae con respecto al grupo que fue infectado y no recibió el probiótico, pero representando una proporción significativamente menor que cuando el probiótico se administró en animales no infectados (grupo P). Comparándolo con el grupo infectado (grupo G), observamos una reducción en la abundancia de la clase Clostridia y también en las proteobacterias, más específicamente en las épsilon proteobacterias; dos clases que se podrían estar relacionados con enfermedades del tracto gastrointestinal. 
A

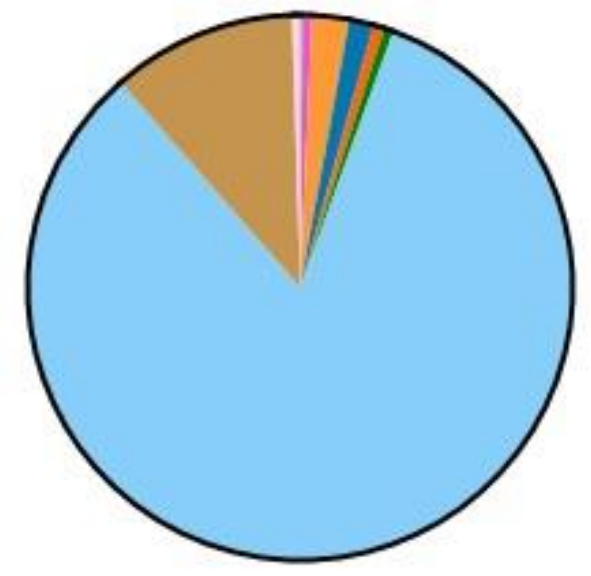

C
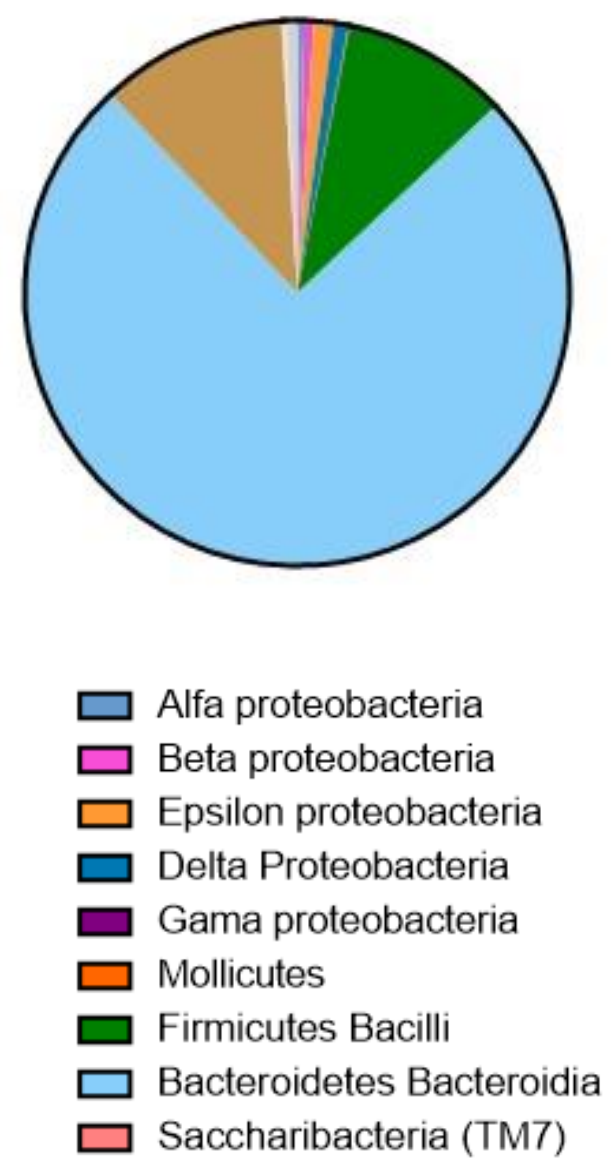

B

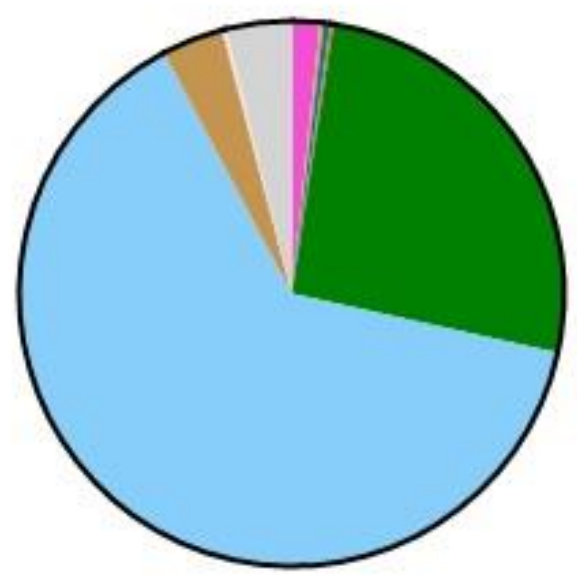

D

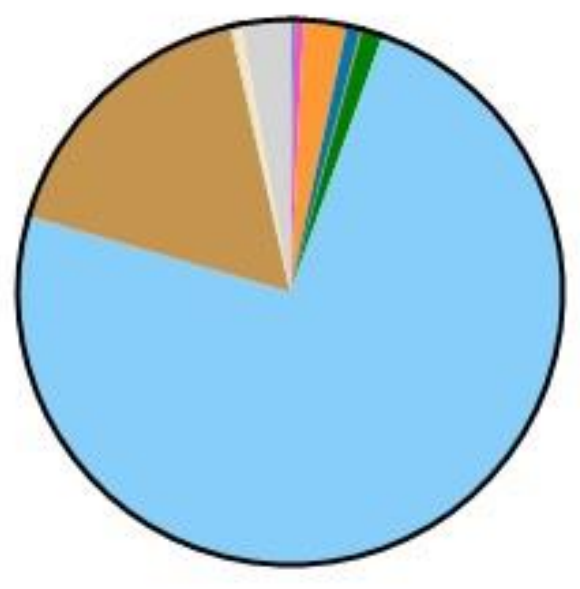

Firmicutes Clostridia Actinobacteria Coriobacteria

Bacteroidetes Flavobacteria

Deferribacterales

Firmicutes Erysipelotrichi

Cyanobacteria

Spirochaetales

Planctobacteria(PVC)

Figura 53: Ver leyenda en página 190. 
Figura 53: Abundancia relativa de las distintas familias bacterianas presentes en las heces de los ratones. C: grupo control sin tratamiento; P: grupo que consumió sólo la cepa probiótica; G: Grupo infectado con Giardia intestinalis cepa H7. PG: Grupo tratado con la cepa probiótica e infectado con Giardia intestinalis cepa H7.

Estos resultados, muestran claramente que la infección por parte del parásito generó un desbalance de la microbiota intestinal, favoreciendo la prevalencia de ciertos microrganismos relacionados con patologías intestinales. Esto sumado a la pérdida de función barrera que Giardia provoca en el epitelio intestinal podría generar la traslocación de estas bacterias patógenas resultando en que el parásito no solo infecte al hospedador, sino que también funcione como un promotor de patologías de origen bacteriano.

En los últimos años, se han realizado numerosas investigaciones acerca de las alteraciones del estado homeostático de la microbiota intestinal y su relación con patologías y manifestaciones clínicas de ciertas enfermedades, sobre todo en las interacciones parásitohospedador (Barash y col., 2017; Beatty y col., 2017; Carding y col., 2015; Leung y col., 2018; Stensvold y col., 2018). En este sentido, la administración del probiótico parece evitar esta disbiosis generada por el parásito, disminuyendo la abundancia de las clases Clostridia y proteobacterias, en los cuales abundan microorganismos de carácter patógeno.

Las investigaciones de las relaciones entre la microbiota intestinal y la salud del individuo abren un nuevo espectro terapéutico en el cual los probióticos se posicionan como protagonistas. El presente trabajo logró demostrar que la administración de un producto probiótico es capaz de modular la microbiota intestinal disminuyendo la cantidad de microorganismos oportunistas que puedan aprovecharse del daño en la función barrera producido por Giardia. 


\subsection{CONCLUSIONES}

En esta segunda parte del presente trabajo de tesis se evaluó el efecto de diferentes productos, tanto frescos como deshidratados, frente a la invasión por parte de Giardia en diferentes sistemas experimentales, que incluyeron efecto directo sobre la proliferación de trofozoitos así como también la utilización de modelos de células de epitelio intestinal humano en cultivo y modelo murino de infección, se indagó en aspectos relevantes de la relación del parásito con el huésped.

Con los modelos in vitro se logró determinar el efecto de los sobrenadantes sobre el crecimiento del parásito y se constató que la neutralización elimina el efecto inhibitorio.

La dificultad de avanzar en los in vitro debido a la imposibilidad de evaluación en sistemas que incluyan a los tres actores relevantes para este trabajo (células, parásitos y microorganismos probióticos), llevó a la realización de ensayos in vivo en un modelo murino de infección con $G$. intestinalis cepa $\mathrm{H} 7$ en el cual se elaboró un producto deshidratado elaborado con la cepa de L. plantarum CIDCA 83114 aislada de kefir.

Esta aproximación experimental, permitió observar un efecto protector por parte del producto probiótico deshidratado administrado. Los efectos positivos se evidenciaron en tres ejes fundamentales: la disminución de la intensidad de infección y las alteraciones morfológicas de la mucosa, el efecto inmunomodulador y la capacidad de minimizar el desbalance de la microbiota causado por Giardia cepa H7. 
CONCLUSIÓN GENERAL Y PERSPECTIVAS 


\section{CONCLUSIÓN GENERAL Y PERSPECTIVAS}

El término "alimento funcional" surgió en la década del 80 en Japón, como una forma de describir a aquellos alimentos que poseen ingredientes que resultan en un beneficio para el consumidor. Los productos probióticos representan uno de los grupos de alimentos funcionales más importantes, lo que se refleja en los estudios de mercado que vaticinan un crecimiento exponencial de esta rama de la industria alimentaria. La creciente información disponible y el grado de concientización acerca de la alimentación y su influencia en el bienestar llevan a los consumidores a cambiar sus preferencias, lo que explicaría este fenómeno. De esta manera, la industria alimentaria debe constantemente generar innovaciones y tecnologías en este sentido, satisfaciendo la necesidad de los consumidores.

Hasta ahora, los productos lácteos fermentados y no fermentados han sido utilizados como los productos alimenticios comerciales más exitosos para suministrar bacterias probióticas. Pero estos productos requieren de un alto costo en logística, distribución y almacenamiento, y además, la diversificación del mercado genera la necesidad de tener nuevas presentaciones. La producción de cultivos deshidratados de microorganismos probióticos surge como una innovadora alternativa, ya que éstos requieren menor capacidad de almacenamiento y menores costos de transporte y refrigeración. La tecnología de secado spray es una alternativa tecnológica comprobada exitosamente para la deshidratación de microrganismos probióticos. Además, cuenta con otras ventajas muy importantes, como su bajo costo comparado con otras tecnologías como la liofilización, la capacidad de permitir la producción continua de grandes cantidades de producto, y, la capacidad instalada existente. Sin embargo, es necesario realizar estudios para garantizar el carácter probiótico y el comportamiento durante el almacenamiento de los productos deshidratados.

En consonancia con las tendencias actuales y la necesidad de producir nuevos alimentos funcionales, fundamentalmente deshidratados (como ya han planteado la FAO y la OMS), 
se planteó el desarrollo de un suplemento probiótico deshidratado a partir de kefir, pensándolo tanto como una nueva presentación de este producto, así como un posible aditivo a diversas matrices alimentarias. El foco de este desarrollo se centró en la conservación de las propiedades probióticas en general y la posible acción protectora frente a la infección por parte de Giardia, en particular, debido a la gran prevalencia de este parásito en países en desarrollo.

En la primera parte se evaluaron distintas estrategias para la obtención de un producto deshidratado a partir de kefir, que conserve su carácter probiótico, y que además sea estable durante su almacenamiento. De este modo, todas las estrategias se focalizaron en obtener un producto con alta viabilidad bacteriana, para que sea considerado como probiótico, y una aW lo suficientemente baja, para que el producto deshidratado se conserve durante su almacenamiento.

Una vez obtenidas las condiciones óptimas de operación del secador spray para la deshidratación de kefir, se buscaron estrategias para aumentar la viabilidad, y optimizar también otros parámetros evaluados, como el contenido de humedad del producto obtenido y el rendimiento del proceso. La utilización de diferentes suspensiones carrier conteniendo $20 \%(\mathrm{p} / \mathrm{v})$ de sólidos para deshidratar los microorganismos del kefir permitió mejorar dichos parámetros, obteniéndose productos con $8,6 \log \mathrm{UFC} / \mathrm{g}$ de bacterias lácticas en promedio y una actividad de agua inferior a 0,3. Sin embargo, se observó que las levaduras presentes en el kefir poseen una baja resistencia al estrés térmico que representa el secado spray, lo que hace que luego no puedan resistir el pasaje por el tracto gastrointestinal o el almacenamiento prolongado.

Se evaluaron carriers con distinta composición y el efecto de la neutralización antes del proceso de deshidratación. Los productos obtenidos mostraron características muy similares 
en los parámetros evaluados, pero mediante el análisis de componentes principales se pudo establecer que una combinación de leche descremada con permeado de suero o maltodextrina y sin neutralizar permitía obtener un producto con la mayor viabilidad de bacterias lácticas y la menor actividad de agua. Además, la presencia de leche descremada como componente del carrier mejoró la supervivencia de las bacterias lácticas a las condiciones gastrointestinales simuladas.

Como ya fue mencionado, la caracterización de los productos, si bien contempló diversos aspectos, se focalizó en las propiedades probióticas. Comprobamos que todos los productos deshidratados fueron capaces de acidificar leche UHT, lo que indica que las bacterias presentes en dichos productos conservaron su capacidad acidificante tras el proceso de deshidratación. Es sabido que la producción de ácidos por parte de las bacterias lácticas posee efectos inhibitorios frente al desarrollo de patógenos, efecto que fue corroborado para todos los productos obtenidos frente a 3 cepas de Salmonella enterica serovar Enteritidis. Debido a que las propiedades probióticas de las bacterias lácticas dependen de la cepa, se buscaron formas de estudiar la composición microbiana de los productos deshidratados. Esto se llevó a cabo sobre la población viable en la cual, mediante secuenciación del gen que codifica para ARNr 16S, se pudo demostrar la prevalencia de Lactobacillus, en especial $L$. plantarum y de Enterococcus. Además, todos los productos obtenidos mantuvieron la viabilidad de bacterias lácticas y su actividad de agua a los mismos valores que el producto recién elaborado durante 60 días de almacenamiento a $4{ }^{\circ} \mathrm{C}$.

Los promisorios resultados obtenidos para la deshidratación de microorganismos del kefir utilizando carriers, llevaron a evaluar la factibilidad del escalado del proceso, mostrando resultados comparables a los obtenidos a escala laboratorio. Además, se pudo establecer que una diferencia de $5{ }^{\circ} \mathrm{C}$ en la temperatura de salida no tiene gran influencia en los parámetros 
evaluados durante la caracterización del producto. Más aún, se mostró que si los productos se almacenan a $20^{\circ} \mathrm{C}$ la viabilidad bacteriana sólo se conservó durante 25 días.

En la segunda parte del trabajo se realizaron estudios in vitro e in vivo para indagar acerca del efecto protector de los productos deshidratados frente a la infección por parte de Giardia intestinalis cepa H7. Los estudios sobre la proliferación del parásito in vitro mostraron que el pH afectó negativamente a los trofozoitos de Giardia impidiendo su correcto desarrollo. Los estudios in vitro sobre células se vieron dificultados por limitaciones propias del modelo que impidieron evaluar juntos los tres actores de esta historia: células, parásitos y producto deshidratado.

Lo anteriormente expuesto, condujo a la realización de ensayos en modelo un murino de infección. Para estos ensayos in vivo se administró una cepa probiótica de L. plantarum deshidratada por secado spray en las condiciones optimizadas en la primera parte de la tesis, utilizando como sustrato permeado de suero. La posibilidad de elaborar un producto funcional a partir de permeado de suero le otorgaría un valor agregado a este subproducto de la industria láctea. El producto deshidratado obtenido mostró elevada viabilidad microbiológica y baja actividad de agua, parámetros que se mantuvieron inalterados durante al menos 30 días de almacenamiento a $4^{\circ} \mathrm{C}$, y además conservó la capacidad de acidificar leche UHT.

Aplicado entonces en el modelo murino de infección, se comprobó que la administración de este producto disminuyó la cantidad de trofozoitos en el intestino y el acortamiento de las vellosidades intestinales causada por Giardia. Además, el producto mostró propiedades inmunomoduladoras, estimulando la producción de citoquinas para desencadenar una respuesta Th2, incluso durante el transcurso de la infección donde Giardia regula negativamente la expresión de citoquinas. En contraste con otros estudios donde se observó 
la modificación de poblaciones celulares relevantes en órganos hematopoyéticos murinos (Ej.: bazo), no se encontraron modificaciones en las subpoblaciones mieloides en medula ósea. Este hallazgo podría tener relación con el carácter transitorio de la infección por Giardia en el modelo murino. La administración del producto probiótico mostró la capacidad de modular la microbiota en favor de géneros asociados con beneficios para la salud del tracto gastrointestinal.

Por otra parte, se demostró que la infección por Giardia produjo un desbalance en la microbiota a favor de géneros asociados con patologías intestinales el cual puede ser minimizado mediante la administración del producto probiótico elaborado.

Los resultados obtenidos en este trabajo sugieren que el secado spray utilizando suspensiones carrier constituye una herramienta tecnológica válida para el desarrollo de productos probióticos a partir de kefir o de cepas aisladas de éste. El proceso de deshidratación optimizado puede ser escalado con éxito, convirtiéndolo en una alternativa para la producción industrial de probióticos. La administración de un producto probiótico obtenido mediante este método mostro tener propiedades antagonistas frente a Giardia, capacidad inmunomoduladora y de regulación de la microbiota.

Este es el primer reporte que demuestra el efecto de producto probiótico a base de permeado de suero y deshidratado mediante secado spray in vivo, lo que resulta ventajoso frente a otras formas de administración. Además, el presente trabajo de tesis representa un recorrido paso a paso desde la optimización de un proceso tecnológico para la obtención de un producto hasta a las pruebas in vivo para demostrar su funcionalidad; abriendo numerosas perspectivas en diversos ámbitos de estudio y aplicación.

Desde el punto de vista del desarrollo de un producto probiótico deshidratado a partir de kefir, es necesario ahondar en metodologías que permitan una mayor supervivencia de las 
levaduras debido a la relevancia de este grupo dentro de los probióticos. Además, es preciso profundizar en la caracterización de los productos deshidratados y en la aceptabilidad sensorial de los mismos por parte de los potenciales consumidores, así como estudiar su posible incorporación en diferentes alimentos para otorgarles un valor agregado como alimento funcional.

En lo que respecta a la evaluación del efecto antagónico frente a Giardia, es importante desarrollar nuevos modelos de estudio que permitan incluir a todos los elementos relevantes del sistema. Esto permitirá indagar acerca de los mecanismos puestos en juego para dotar de una base racional a la utilización de probióticos en el contexto de la infección con Giardia. En este ámbito, sería de altísima relevancia la utilización del modelo in vivo en merión, ya que éste ha demostrado ofrecer una visión más completa de la infección por parte de Giardia en humanos. En base a los resultados del presente estudio, sería relevante analizar los cambios en la microbiota que produce Giardia en meriones debido a la escasa información existente al respecto.

Como aspecto final a tener en cuenta, es de destacar que, si bien es cierto que el efecto de los microorganismos probióticos está documentado con una amplia variedad de estudios a diferentes niveles, el estado actual del conocimiento científico-tecnológico así como también la demanda de los consumidores, hacen que sean necesarios nuevos elementos que contribuyan a la comprensión de la base racional de los mecanismos de acción de los alimentos probióticos. Este trabajo de tesis doctoral se enmarca en este recorrido necesario entre aspectos básicos y aplicados imprescindibles teniendo en cuenta la complejidad de las interacciones puestas en juego. 
ANEXO 


\section{Medio de Cultivo y Buffers Utilizados}

Todos los medios de cultivo y buffers se esterilizaron en autoclave a $120{ }^{\circ} \mathrm{C}$ durante 15 minutos, excepto los casos indicados

\section{Caldo MRS (Difco, EEUU)}

\begin{tabular}{|l|l|}
\hline Componente & Para $1000 \mathrm{ml}$ \\
\hline Peptona & $10 \mathrm{~g}$ \\
\hline Extracto de carne & $5 \mathrm{~g}$ \\
\hline Extracto de levadura & $5 \mathrm{~g}$ \\
\hline $\mathbf{D}(+)$ glucosa & $20 \mathrm{~g}$ \\
\hline $\mathrm{K}_{2} \mathrm{HPO}_{4}$ & $2 \mathrm{~g}$ \\
\hline $\mathrm{Tween}_{\mathbf{8 0}}$ & $1 \mathrm{~g}$ \\
\hline Citrato ácido de amonio & $2 \mathrm{~g}$ \\
\hline Acetato de sodio & $5 \mathrm{~g}$ \\
\hline $\mathrm{MgSO}_{4}$ & $0,1 \mathrm{~g}$ \\
\hline $\mathrm{MnSO}_{4}$ & $0,05 \mathrm{~g}$ \\
\hline $\mathbf{H}_{\mathbf{2}} \mathbf{O}$ & C.s.p $1000 \mathrm{ml}$ \\
\hline & $\mathbf{p H = 6 , 4 - 6 , 6}$ \\
\hline
\end{tabular}

\section{Agar MRS}

Caldo MRS adicionado adicionado con 1,5 g/l de agar-agar.

Caldo nutritivo (Biokar, Francia)

\begin{tabular}{|l|l|}
\hline Componente & Para $1000 \mathrm{ml}$ \\
\hline Extracto de carne & $3 \mathrm{~g}$ \\
\hline Extracto de carne & $5 \mathrm{~g}$ \\
\hline $\mathbf{H}_{\mathbf{2}} \mathbf{O}$ & C.s.p $1000 \mathrm{ml}$ \\
\hline & $\mathbf{p H}=\mathbf{6 , 8} \mathbf{- 7 , 2}$ \\
\hline
\end{tabular}

\section{Agar Nutritivo}

Caldo Nutritivo adicionado con 1,5 g/l de agar-agar. 
YGC (Yeast Extract Glucose Chloramphenicol Agar) (Merck, Alemania)

\begin{tabular}{|l|l|}
\hline Componente & Para $1000 \mathrm{ml}$ \\
\hline Extracto de levadura & $5 \mathrm{~g}$ \\
\hline Glucosa & $20 \mathrm{~g}$ \\
\hline Cloranfenicol & $0,1 \mathrm{~g}$ \\
\hline Agar-agar & $14,9 \mathrm{~g}$ \\
\hline $\mathbf{H}_{\mathbf{2}} \mathrm{O}$ & C.s. $\mathbf{p ~} 1000 \mathrm{ml}$ \\
\hline & $\mathbf{p H}=\mathbf{6 , 5}-\mathbf{6 , 6}$ \\
\hline
\end{tabular}

Medio Keister's modificado (TYI-S-33)

\begin{tabular}{|l|l|}
\hline Componente & Para $1000 \mathrm{ml}$ \\
\hline Digerido de caseína & $20 \mathrm{~g}$ \\
\hline Extracto de levadura & $10 \mathrm{~g}$ \\
\hline Dextrosa & $10 \mathrm{~g}$ \\
\hline Bilis bovina & $0,75 \mathrm{~g}$ \\
\hline $\mathrm{NaCl}$ & $2 \mathrm{~g}$ \\
\hline L-Cisteína.HCl & $2 \mathrm{~g}$ \\
\hline Ácido ascórbico-sal sódica & $0,2 \mathrm{~g}$ \\
\hline $\mathrm{K}_{2} \mathrm{HPO}_{4}$ & $0,6 \mathrm{~g}$ \\
\hline $\mathrm{KH}_{2} \mathrm{PO}_{4}$ & $0,05 \mathrm{~g}$ \\
\hline Citrato férrico- amónico & $0,228 \mathrm{~g}$ \\
\hline Suero bovino adulto & $100 \mathrm{ml}$ \\
\hline Penicilina & $0,0624 \mathrm{~g}$ \\
\hline Estreptomicina & $0,1 \mathrm{~g}$ \\
\hline $\mathrm{H}_{2} \mathrm{O}$ & c.s.p $1000 \mathrm{ml}$ \\
\hline & \\
\hline
\end{tabular}

El suero bovino se inactivo durante $30 \mathrm{~min}$ a $60^{\circ} \mathrm{C}$. El pH se ajustó a pH 6.9 con $\mathrm{NaOH} 5 \mathrm{~N}$ previo a la esterilización por filtración a través de una membrana de $0,22 \mu \mathrm{m}$. 


\section{Medio MTYI}

\begin{tabular}{|l|l|}
\hline Componente & Para $1000 \mathrm{ml}$ \\
\hline Digerido de caseína & $20 \mathrm{~g}$ \\
\hline Extracto de levadura & $10 \mathrm{~g}$ \\
\hline Dextrosa & $20 \mathrm{~g}$ \\
\hline $\mathrm{NaCl}$ & $2 \mathrm{~g}$ \\
\hline L-Cisteína.HCl & $2 \mathrm{~g}$ \\
\hline Ácido ascórbico-sal sódica & $0,2 \mathrm{~g}$ \\
\hline $\mathrm{K}_{2} \mathrm{HPO}_{4}$ & $0,6 \mathrm{~g}$ \\
\hline $\mathrm{KH}_{2} \mathrm{PO}_{4}$ & $0,05 \mathrm{~g}$ \\
\hline Tween $_{\mathbf{8 0}}$ & $1 \mathrm{~g}$ \\
\hline Suero bovino adulto & $100 \mathrm{ml}$ \\
\hline $\mathrm{H}_{2} \mathrm{O}$ & c.s.p $1000 \mathrm{ml}$ \\
\hline & \\
\hline
\end{tabular}

El suero bovino se inactivo durante $30 \mathrm{~min}$ a $60^{\circ} \mathrm{C}$. El pH se ajustó a pH 7,0 con $\mathrm{NaOH} 5 \mathrm{~N}$ previo a la esterilización por filtración a través de una membrana de $0,22 \mu \mathrm{m}$.

DMEM (Dulbecco modified Eagle's minimal essential medium) completo

\begin{tabular}{|c|c|}
\hline Componente & Para $1000 \mathrm{ml}$ \\
\hline DMEM (Gibco, EEUU) & 1 sobre \\
\hline Suero Fetal Bovino & $180 \mathrm{ml}$ \\
\hline Aminoácidos no esenciales (100X) & $13 \mathrm{ml}$ \\
\hline Penicilina / Estreptomicina (1000 UI, 1000 g/ml) & $13 \mathrm{ml}$ \\
\hline Gentamicina (50 mg/ml) & $10 \mathrm{ml}$ \\
\hline $\mathrm{NaHCO}_{3}$ & $2 \mathrm{~g}$ \\
\hline $\mathrm{H}_{2} \mathrm{O}$ & c.s.p $1000 \mathrm{ml}$ \\
\hline
\end{tabular}

El suero fetal bovino se inactivó $30 \mathrm{~min}$ a $60^{\circ} \mathrm{C}$. Una vez preparado, el medio se esterilizó por filtración a través de una membrana de $0,22 \mu \mathrm{m}$. 


\section{DMEM Adhesión}

\begin{tabular}{|c|c|}
\hline Componente & Para $1000 \mathrm{ml}$ \\
\hline DMEM & 1 sobre \\
\hline $\mathrm{NaHCO}_{3}$ & $2 \mathrm{~g}$ \\
\hline $\mathrm{H}_{2} \mathrm{O}$ & c.s.p $1000 \mathrm{ml}$ \\
\hline \multicolumn{2}{|c|}{$\mathrm{pH}=6,9-7,2$} \\
\hline
\end{tabular}

Una vez preparado, el medio se esterilizó por filtración a través de una membrana de 0,22 $\mu \mathrm{m}$.

\section{PBS}

\begin{tabular}{|c|c|}
\hline Componente & Para $1000 \mathrm{ml}$ \\
\hline $\mathrm{NaCl}$ & $8,02 \mathrm{~g}$ \\
\hline $\mathrm{KCl}$ & $0,231 \mathrm{~g}$ \\
\hline $\mathrm{Na}_{2} \mathrm{HPO}_{4}$ & $1,17 \mathrm{~g}$ \\
\hline $\mathrm{KH}_{2} \mathrm{PO}_{4}$ & $0,2 \mathrm{~g}$ \\
\hline $\mathrm{H}_{2} \mathrm{O}$ & c.s.p $1000 \mathrm{ml}$ \\
\hline
\end{tabular}

\section{Buffer de Lisis:}

\begin{tabular}{|l|l|l|}
\hline Componente & Para $100 \mathrm{ml}$ & Concentración Final \\
\hline Tris $\mathbf{1 M}(\mathbf{p H = 8})$ & $2 \mathrm{ml}$ & $20 \mathrm{mM}$ \\
\hline EDTA $\mathbf{0 , 5 M}(\mathbf{p H = 8})$ & $0,4 \mathrm{ml}$ & $2 \mathrm{mM}$ \\
\hline Triton $\mathbf{X}-\mathbf{1 0 0}$ & $1,2 \mathrm{ml}$ & $1,2 \% \mathrm{v} / \mathrm{v}$ \\
\hline $\mathbf{N a C l}$ & $585 \mathrm{mg}$ & $100 \mathrm{mM}$ \\
\hline $\mathbf{H}_{\mathbf{2}} \mathbf{O}$ & c.s.p $100 \mathrm{ml}$ & \\
\hline
\end{tabular}

Reactivos para electroforesis en geles de poliacrilamida en condiciones desnaturalizantes (SDS-PAGE)

Solución Acrilamida-Bisacrilamida 40\%

\begin{tabular}{|l|l|}
\hline Componente & Para $100 \mathrm{ml}$ \\
\hline Acrilamida & $38,93 \mathrm{~g}$ \\
\hline Bisacrilamida & $1,07 \mathrm{~g}$ \\
\hline $\mathbf{H}_{\mathbf{2}} \mathbf{O}$ & c.s.p $100 \mathrm{ml}$ \\
\hline
\end{tabular}


Filtrar con membrana de $0,45 \mu \mathrm{m}$.y conservar en frasco color caramelo a $4{ }^{\circ} \mathrm{C}$.

Buffer Muestra

\begin{tabular}{|l|l|}
\hline Componente & Para $10 \mathrm{ml}$ \\
\hline Azul de Bromofenol $\mathbf{2 \%}$ & $0,25 \mathrm{ml}$ \\
\hline Xileno cianol $\mathbf{2 \%}$ & $0,25 \mathrm{ml}$ \\
\hline Glicerol $\mathbf{1 0 0 \%}$ & $\mathbf{7 ~ m l}$ \\
\hline $\mathbf{H}_{\mathbf{2}} \mathbf{O}$ & c.s.p $10 \mathrm{ml}$ \\
\hline
\end{tabular}

Persulfato de Amonio 10\%

\begin{tabular}{|l|l|}
\hline Componente & Para $10 \mathrm{ml}$ \\
\hline Persulfato de Amonio & $1 \mathrm{~g}$ \\
\hline $\mathbf{H}_{\mathbf{2}} \mathbf{O}$ & c.s.p $10 \mathrm{ml}$ \\
\hline
\end{tabular}

Preparar en el momento de uso o conservar congelado.

Solución stacking

\begin{tabular}{|l|l|}
\hline Componente & Para $10 \mathrm{ml}$ \\
\hline Temed & $10 \mu \mathrm{l}$ \\
\hline Persulfato de Amonio $\mathbf{1 0 \%}$ & $10 \mu \mathrm{l}$ \\
\hline Acrilamida $\mathbf{0 \%}$ & c.s.p $10 \mathrm{ml}$ \\
\hline
\end{tabular}

Solución de tinción

\begin{tabular}{|l|l|}
\hline Componente & Para $10 \mathrm{ml}$ \\
\hline SybrGold & $200 \mu \mathrm{l}$ \\
\hline Buffer TAE & c.s.p $1000 \mathrm{ml}$ \\
\hline
\end{tabular}


Ejemplo del análisis efectuado para la determinación de las distintas subpoblaciones hematopoyéticas en medula ósea. El recuento diferencial de las células fue llevado a cabo con un citómetro de flujo (FACScalibur, Becton Dickinson, EEUU), luego de hacer una región en la población de células viables en el gráfico forward scatter (FSC) vs side scatter (SSC) como se muestra a continuación (Figura 54 A). Para establecer potencia del láser se utilizaron células sin marca, y la compensación se realizó sobre células con simple marcado. Ver sección 2.3.3.8 para ver anticuerpos utilizados y método empleado.

Una vez seleccionadas las células viables (Figura 54 A), se evaluó FL-1 (CD34-FITC) vs SSC, donde se seleccionaron las células madre hematopoyéticas (CD34+) (Figura 54 B). Dentro del gate CD34+, se examinó FL-2 (CD117-PE) vs SSC, separando las células pluripotenciales comprometidas en linaje mieloide $(\mathrm{CD} 117+)$, de aquellas que se hallan comprometidas con el linaje linfoide (CD117-)(Figura 54 C).

Luego, dentro de la subpoblación CD117+, se evaluó FL-4 (Lin -APC) vs SSC para establecer la células de linaje mieloide maduro (Lin+)(Figura 54 E); mientras que en la subpoblación CD117-, se evaluó FL-3 (Ly6A/E-Biot/St) vs SSC para establecer células de linaje linfoide maduro (Ly6A/E+) (Figura $54 \mathrm{D})$. 

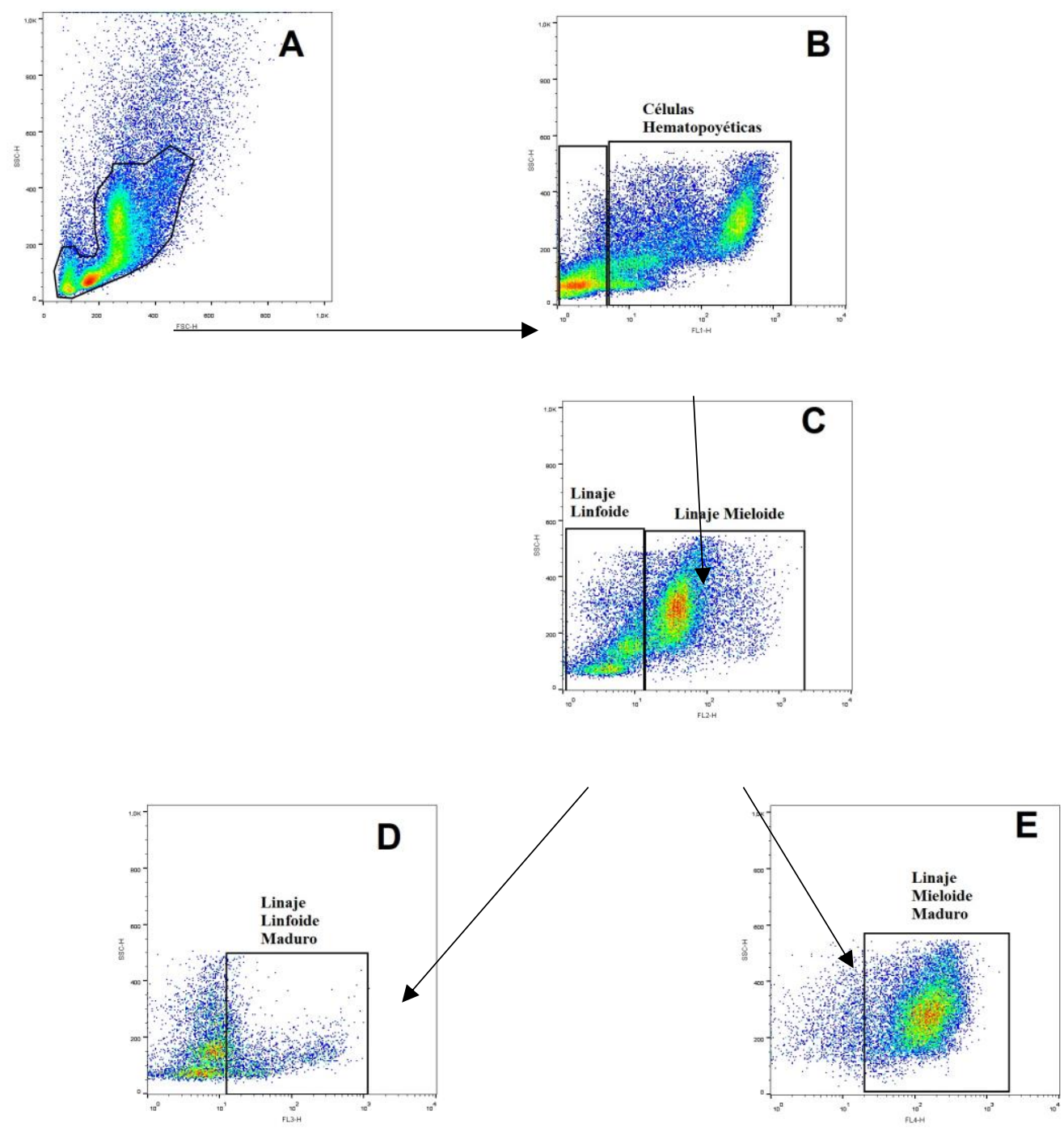

Figura 54: Esquema ejemplo del análisis por citometría de flujo de las diferentes subpoblaciones y linajes celulares en médula ósea.

Para le detección de las distintas subpoblaciones dentro de las células de linaje mieloide maduras, se procedió del siguiente modo. Una vez seleccionadas las células viables en el gráfico forward scatter (FSC) vs side scatter (SSC) (Figura 55 A), se evaluó FL-1 (Ly6GFITC) vs SSC (Figura 55 B), que me permite separar la subpoblación Ly6G +, de la Ly6G -. Para la identificación de los neutrófilos se examinó dentro de la subpoblación Ly6G+ el gráfico FL-2 (Gr-1-PE) vs SCC, donde aquella subpoblación Gr-1+ corresponde a este tipo 
celular. Por su parte, dentro de la subpoblación Ly6G-, se examinó el gráfico de FL-3 (Ly6C-

Biot/St), que separa Monocitos (Ly6C+) de Eosinófilos (Ly6C-) (Figura 55 D).

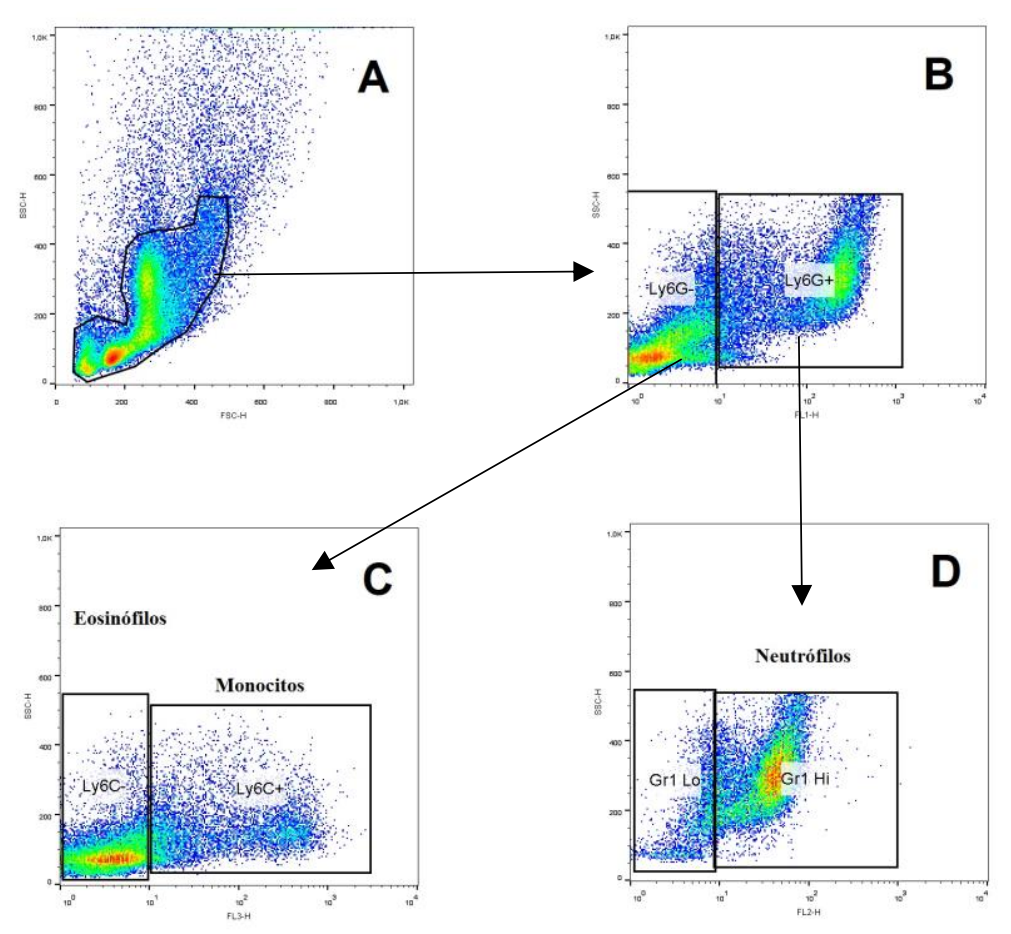

Figura 55: Esquema ejemplo del análisis por citometría de flujo de las diferentes subpoblaciones celulares maduras pertenecientes al linaje mieloide. 
REFERENCIAS BIBLIOGRÁFICAS 
Abadias, M., Teixido, N., Usall, J., Benabarre, A., \& Vinas, I. (2001). Viability, efficacy, and storage stability of freeze-dried biocontrol agent Candida sake using different protective and rehydration media. Journal of Food Protection, 64, 856-861.

Abbas, H. A.; Serry, F. M. \& El-Masry, E. M. (2012). Synergic interaction between antibiotics and the artificial sweeteners xylitol and sorbitol against Pseudomonas aeruginosa biofilms. Asian J. Pharm. Vol. 2: Issue 4, 129-131

Adams, M. R., \& Hall, C. J. (1988). Growth inhibition of food-borne pathogens by lactic and acetic acids and their mixtures. International Journal of Food Science \& Technology, 23(3), 287292.

Ahmed, Z., Wang, Y., Ahmad, A., Khan, S. T., Nisa, M., Ahmad, H., \& Afreen, A. (2013). Kefir and health: A contemporary perspective. Critical Reviews in Food Science and Nutrition, 53, 422-434.

Al-Rousan, W. M., Olaimat, A. N., Osaili, T. M., Al-Nabulsi, A. A., Ajo, R. Y., \& Holley, R. A. (2018). Use of acetic and citric acids to inhibit Escherichia coli O157:H7, Salmonella Typhimurium and Staphylococcus aureus in tabbouleh salad. Food Microbiology, 73, 61-66.

Allen, J. E., \& Sutherland, T. E. (2014). Host protective roles of type 2 immunity: Parasite killing and tissue repair, flip sides of the same coin. Seminars in Immunology, 26(4), 329-340.

Amat, C., Motta, J.P., Bhargava, A., Chadee, K. \& Buret, A.G. (2015). Giardia duodenalis depletes goblet cell mucins and degrades MUC2, facilitating bacterial translocation. FASEB J. 2015; 29(1):507.1.

Ananta, E., Volkert, M., \& Knorr, D. (2005). Cellular injuries and storage stability of spray-dried Lactobacillus rhamnosus GG. International Dairy Journal, 15(4), 399-409.

Andersen, H. D., Wang, C., Arleth, L., Peters, G. H., \& Westh, P. (2011). Reconciliation of opposing views on membrane-sugar interactions.

Proceedings of the National Academy of Sciences of the United States of America, 108(5), 1874-1878.

Ankarklev, J., Jerlstrom-Hultqvist, J., Ringqvist, E., Troell, K. \& Svard, S.G. (2010). Behind the smile: cell biology and disease mechanisms of Giardia species. Nat Rev Microbiol; 8: 413-422

Annunziato, F., Romagnani, C., \& Romagnani, S. (2015). The 3 major types of innate and adaptive cell-mediated effector immunity. Journal of Allergy and Clinical Immunology, 135(3), 626-635.

Arao, T., Suzuki, Y., \& Tamura, K. (2002). Effects of saccharide in medium on stress tolerance of yeast. Progress in Biotechnology, 19, 331-336.

Araújo, N. S., Mundim, M. J. S., Gomes, M. A., Amorim, R. M. R., Viana, J. C., Queiroz, R. P. \& Cury, M. C. (2008). Giardia duodenalis: Pathological alterations in gerbils, Meriones unguiculatus, infected with different dosages of trophozoites. Experimental Parasitology, 118(4), 449-457.

Arslan, S., Erbas, M., Tontul, I., \& Topuza, A. (2015). Microencapsulation of probiotic Saccharomyces cerevisiae var.boulardii with different wall materials 
by spray drying. LWT - Food Science and Technology, 63, 685-690.

Arpagaus, C., and Schwartzbach, $\mathrm{H}$. (2008). Büchi AG. Scale-up from benchtop research to laboratory production.best@buchi Information Bulletin No. 52/2008.

Arumugam, M., Raes, J., Pelletier, E., Le Paslier, D., Yamada, T., Mende, D. R. \& Batto, J.M. (2011). Enterotypes of the human gut microbiome. Nature, 473(7346), 174-180.

Aschenbrenner, M.; Grammueller, E.; Kulozik, U. \& Foerst,P. (2014) The contribution of the inherent restricted mobility of glassy sugar matrices to the overall stability of freeze dried bacteria determined by low-resolution solid-state H-NMR. Food Bioprocess Technol. 7 (4), 1012-1024.

Assadi, M. M., Pourahmad, R., \& Moazami, N. (2000). Use of isolated kefir starter cultures in kefir production. World Journal of Microbiology and Biotechnology, 16, 541-543.

Atalar, I., \& Dervisoglu, M. (2015). Optimization of spray drying process parameters for kefir powder using response surface methodology. LWT Food Science and Technology, 60, 751757.

Athanasiadis, I., Boskou, D., Kanellaki, M., Kiosseoglou, V., \& Koutinas, A. A. (2002). Whey liquid waste of the dairy industry as raw material for potable alcohol production by kefir granules. Journal of Agricultural and Food Chemistry, 50(25), 7231-7234.

Ávila-Reyes, S.V., García-Suarez, F. J.; Jiménez, M. T.; San Martín-González, M. F. \& Bello-Pérez, L. A. (2014) Protection of Lactobacillus rhamnosus by spraydrying using two prebiotics colloids to enhance the viability. Carbohydr. Polym. 102, 423-430.
Badui, S. (2006). Química de los alimentos, $4^{\mathrm{a}}$ edición.

Barash, N. R., Maloney, J. G., Singer, S. M., \& Dawson, S. C. (2017). Giardia alters commensal microbial diversity throughout the murine gut. Infection and Immunity, 85(6).

Barbosa, J., Borges, S., Amorim, M., Pereira, M. J., Oliveira, A., Pintado, M. E., \& Teixeira, P. (2015). Comparison of spray drying, freeze drying and convective hot air drying for the production of a probiotic orange powder. Journal of Functional Foods, 17, 340-351

Barbosa Canovas, G. V., \& Vega Mercado, H. (1996).Dehydration of foods. New York: Chapman and Hall.

Barbosa Canovas, G. V., Ortega-Rivas, E., Juliano, P., \& Yan, H. (2005). Food powders: Physical properties, processing, and functionality. New York: Kluwer Academic/Plenum Publishers.

Bartelt, L.A. \& Sartor, R.B. (2015). Advances in understanding Giardia: determinants and mechanisms of chronic sequelae. F1000Prime Rep 7:62.

Beatty, J. K., Akierman, S. V., Motta, J.P., Muise, S., Workentine, M. L., Harrison, J. J. \& Buret, A. G. (2017). Giardia duodenalis induces pathogenic dysbiosis of human intestinal microbiota biofilms. International Journal for Parasitology, 47(6), 311-326.

Beausoleil M., Fortier N., Guénett S., L'Ecuyer A., Savoie M., Franco M., Lachaîne J. y Weiss K. (2007). Effect of a fermented milk combining Lactobacillus acidophilus CL1285 and Lactobacillus casei in the prevention of antibiotic-associated diarrhea: a randomized, doubled-blind, placebocontrolled trial. Canadian Journal of Gastroenterology. 21 (11): 732-736.

Behboudi-Jobbehdar, S., Soukoulis, C., Yonekura, L. \& Fisk, I. (2013). Optimization of spray-drying process 
conditions for the production of maximally viable microencapsulated L. acidophilus NCIMB 701748. Drying Technology.31(11):1274-1283.

Belizário, J. E. \& Napolitano, M. (2015). Human microbiomes and their roles in dysbiosis, common diseases, and novel therapeutic approaches. Frontiers in Microbiology, 6.

Belosevic, M., Faubert, G. M., MacLean, J. D., Law, C., \& Croll, N. A. (1983). Giardia lamblia Infections in Mongolian Gerbils: An Animal Model. Journal of Infectious Diseases, 147(2), 222-226.

Bengoa, A. A., Zavala, L., Carasi, P., Trejo, S. A., Bronsoms, S., Serradell, M. \& Abraham, A. G. (2018). Simulated gastrointestinal conditions increase adhesion ability of Lactobacillus paracasei strains isolated from kefir to Caco-2 cells and mucin. Food Research International, 103, 462-467.

Bengoa, A. A., Iraporda, C., Garrote, G. L., \& Abraham, A. G. (2019). Kefir micro- organisms: their role in grain assembly and health properties of fermented milk. Journal of applied microbiology, 126(3), 686-700.

Benyacoub, J., Pérez, P. F., Rochat, F., Saudan, K. Y., Reuteler, G., Antille, N., Humen ,M., De Antoni, G. L., Cavadini,C., Blum, S. \& Schiffrin, E. J. (2005). Enterococcus faecium SF68 Enhances the Immune Response to Giardia intestinalis in Mice. The Journal of Nutrition, 135(5), 1171-1176.

Bergmann, R. S. de O., Pereira, M. A., Veiga, S. M. O. M., Schneedorf, J. M., Oliveira, N. de M. S., \& Fiorini, J. E. (2010). Microbial profile of a kefir sample preparations: grains in natura and lyophilized and fermented suspension. Ciência e Tecnologia de Alimentos, 30(4), 1022-1026.

Bhuvaneswari, S.; Sripriya, N. \& Nyayiru Kannaian, U. P. (2015). Ajinomoto:
Antibacterial Impact. Indian Journal of Applied Microbiology. 18. 28-33.

Biagini, G. A., Knodler, L. A., Saliba, K. J., Kirk, K., \& Edwards, M. R. (2001). $\mathrm{Na}+$-dependent $\mathrm{pH}$ regulation by the amitochondriate protozoan parasite Giardia intestinalis. Journal of Biological Chemistry, 276(31), 29157-29162.

Bolla, P. A., Abraham, A. G., Pérez, P. F., \& Serradell, M. (2016). Kefir-isolated bacteria and yeasts inhibit Shigella flexneri invasion and modulate proinflammatory response on intestinal epithelial cells. Beneficial Microbes, 7(1), 103-110.

Borchers, A.; Selmi, C.; Meyers, F.; Keen, C. \& Gershwin, M. (2009). Probiotics and immunity. Journal of gastroenterology. 44. 26-46.

Bourrie, B. C., Willing, B. P., \& Cotter, P. D. (2016). The microbiota and health promoting characteristics of the fermented beverage kefir. Frontiers in Microbiology, 7, 647.

Boza, Y., Barbin, D. \& Scamparini, A.R.P. (2004). Effect of spray-drying on the quality of encapsulated cell of Beijerinckia spp.. Process Biochemistry. 39. 1275-1284.

Brialy, C., Rivalland, P., Coiffard, L., \& De Roeck Holtzhauer, Y. (1995). Microbiological study of lyophilized dairy kefir. Folia Microbiologica, 40(2), 198-200.

Bryant, G., Koster, K., \& Wolfe, J. (2001). Membrane behaviour in seeds and other systems at low water content: The various effects of solutes. Seed Science Research, 11(1), 17-25.

Buchi Application Note Bulletin Número: 248/207 (2017). Microencapsulation of flavors and fragances by spray drying.Disponible en: https://static1.buchi.com/sites/default/file s/AN_248_2017_flavor_and_fragrance.p df 
Bui, V. T., Tseng, H.-C., Kozlowska, A., Maung, P. O., Kaur, K., Topchyan, P., \& Jewett, A. (2015). Augmented IFN- $\gamma$ and TNF- $\alpha$ induced by probiotic bacteria in NK cells mediate differentiation of stemlike tumors leading to inhibition of tumor growth and reduction in inflammatory cytokine release; regulation by IL-10. Frontiers in Immunology, 6.

Buret, A., Hardin, J. A., Olson, M. E., \& Gall, D. G. (1992). Pathophysiology of small intestinal malabsorption in gerbils infected with Giardia lamblia. Gastroenterology, 103(2), 506-513.

Buret A.G., (2007) Mechanisms of epithelial dysfunction in giardiasis. Gut.;56(3):316-317.

Buret, A. G., Amat, C. B., Manko, A., Beatty, J. K., Halliez, M. C. M., Bhargava, A., \& Cotton, J. A. (2015). Giardia duodenalis: New Research Developments in Pathophysiology, Pathogenesis, and Virulence Factors. Current Tropical Medicine Reports, 2(3), 110-118.

Burin, R. C. K., Silva, A., \& Nero, L. A. (2014). Influence of lactic acid and acetic acid on Salmonella spp. growth and expression of acid tolerance-related genes. Food Research International, 64, 726-732

Byrd, L. G., Conrad, J. T. \& Nash,T. E.(1994) Giardia lamblia infections in adult mice. Infect Immun.; 62(8):3583-5.

Cacciò, S. M., Lalle, M., \& Svärd, S. G. (2017). Host specificity in the Giardia duodenalis species complex. Infection, Genetics and Evolution. 66:335-345.

Caporaso, J. G., Lauber, C. L., Costello, E. K., Berg-Lyons, D., Gonzalez, A., Stombaugh, J., Knights, D., Gajer, P., Ravel, J., Fierer, N., Gordon, J.I. \& Knight, R. (2011). Moving pictures of the human microbiome. Genome Biology, 12(5), R50.
Carasi, P., Racedo, S. M., Jacquot, C., Romanin, D. E., Serradell, M. A., \& Urdaci, M. C. (2015). Impact of kefir derived Lactobacillus kefiri on the mucosal immune response and gut microbiota. Journal of Immunology Research, 2015, 1-12.

Carding, S., Verbeke, K., Vipond, D. T., Corfe, B. M., \& Owen, L. J. (2015). Dysbiosis of the gut microbiota in disease. Microbial Ecology in Health \& Disease, 26(0).

Cardona, T.D., Driscoll R.H., Paterson, J.L., Srzednicki, G. \& Kim, S.W. (2002). Optimizing conditions for heat pump dehydration of lactic acid bacteria. Drying Technology. 20. 1611-1632.

Carey, C. M., Kostrzynska M., Ojha S. y Thompson S. (2008). The effect of probiotics and organic acids on shigatoxin 2 expression in enterohemorrhagic Escherichia coli O157:H7. Journal of Microbiological Methods. 73 (2): 125132.

Carvalho, A.S.; Silva, J.; Ho, P.; Teixeira, P.; Malcata, F. X. \& Gibbs, P. (2002) Survival of freeze-dried Lactobacillus plantarum and Lactobacillus rhamnosus during storage in the presence of protectants. Biotechnology Letters 24, 1587-1591.

Castillo, N. A., de Moreno de LeBlanc, A., M. Galdeano, C., \& Perdigón, G. (2012). Comparative study of the protective capacity against Salmonella infection between probiotic and non probiotic lactobacilli. Journal of Applied Microbiology, 114(3), 861-876.

Catalioto, R.M., A. Maggi, C., \& Giuliani, S. (2011). Intestinal Epithelial Barrier Dysfunction in Disease and Possible Therapeutical Interventions. Current Medicinal Chemistry, 18(3), 398-426.

Ceu Sousa, M., Goncalves, C. A., Bairos, V. A., \& Poiares-da-Silva, J. (2001). 
Adherence of Giardia lamblia

trophozoites to Int-407 Human Intestinal

Cells. Clinical and Vaccine Immunology, 8(2), 258-265.

Chandralekha, A., Tavanandi, A. H., Amrutha, N., Hebbar, H. U., Raghavarao, K. S. M. S., \& Gadre, R. (2016). Encapsulation of yeast (Saccharomyces cereviciae) by spray drying for extension of shelf life. Drying Technology, 34(11), 1307-1318.

Chávez,B. E., \& Ledeboer, A. M. (2007). Drying of probiotics: Optimization of formulation and process to enhance storage survival. Drying Technology, 25(7-8), 1193-1201.

Chen, H.C.; Lin, C-W. \& Chen, M-J. (2006). The Effects of Freeze Drying and Rehydration on Survival of Microorganisms in Kefir. Asian-Aust. J. Anim. Sci.. Vol 19, No. 1 : 126-130.

Chen, T.L., Chen, H., Wu, H.W., Lee, T.C., Lu, Y.Z. \& Wu, L.L. (2013). Persistent gut barrier damage and commensal bacterial influx after eradication of Giardia infection in mice. Gut Pathog.;26(5):1-12.

Chen, W. (Ed.). (2019). Lactic Acid Bacteria: Bioengineering and Industrial Applications. Springer Publishing Singapore

Chifiriuc, M. C., Cioaca, A. B. \& Lazar, V. (2011) In vitro assay of the antimicrobial activity of kephir against bacterial and fungal strains. Anaerobe; 17:433-435.

Chin, A.C., Teoh, D.A., Scott, K.G., Meddings, J.B., Macnaughton, W.K. \& Buret, A.G. (2002) Strain-dependent induction of enterocytes apoptosis by Giardia lamblia disrupts epithelial barrier function in a caspase-3-dependent manner. Infect Immun.;70(7):3673-80

Chin, A.C., Flynn, A.N., Fedwick, J.P. \& Buret, A.G. (2006)The role of caspase3 in lipopolysaccharide-mediated disruption of epithelial tight junctions.

Can J Physiol Pharmacol.;84(10):104350.

Clegg, J.S.; Seitz, P.; Seits, W. \& Hazlewood, C.F. (1982) Cellular response to extreme water loss: The water-replacement hypothesis. Cryobiology 19, 306-316.

Conde-Islas, A., Jiménez-Fernández, M., Cantú-Lozano, D., Urrea-García, G., \& Luna-Solano, G. (2019). Effect of the Freeze-Drying Process on the Physicochemical and Microbiological Properties of Mexican Kefir Grains. Processes, 7(3), 127.

Corcoran, B. M., Ross, R. P., Fitzgerald, G. F., \& Stanton, C. (2004). Comparative survival of probiotic lactobacilli spraydried in the presence of prebiotic substances. Journal of Applied Microbiology, 96, 1024-1039.

Corcoran, B. M., Stanton, C., Fitzgerald, G. F., \& Ross, R. P. (2005). Survival of Probiotic Lactobacilli in Acidic Environments Is Enhanced in the Presence of Metabolizable Sugars. Applied and Environmental Microbiology, 71, 3060 - 3067.

Correa Franco, M. (2012) Utilización de fermentos lácticos obtenidos a partir de kefir para evaluar su capacidad antagónica in vivo frente al protozoario intestinal Giardia intestinalis. Tesis Magister. UNLP.

Correa Franco, M., Golowczyc, M. A., De Antoni, G. L., Perez, P. F., Humen, M., \& Serradell, M. (2013).

Administration of kefir-fermented milk protects mice against Giardia intestinalis infection. Journal of Medical Microbiology, 62(Pt 12), 1815-1822.

Costello, E. K., Lauber, C. L., Hamady, M., Fierer, N., Gordon, J. I., \& Knight, R. (2009). Bacterial Community Variation in Human Body Habitats Across Space 
and Time. Science, 326(5960), 16941697.

Cotton J. A., Beatty J. K. \& Buret A. G. (2011). Host-parasite interactions and pathophysiology in Giardia infections. Int. J. Parasitol. 41, 925-933

Cotton, J., Amat, C., \& Buret, A. (2015). Disruptions of Host Immunity and Inflammation by Giardia Duodenalis: Potential Consequences for Co-Infections in the Gastro-Intestinal Tract. Pathogens, 4(4), 764-792.

Cui, L., Niu, L., Li, D., Liu, C., Liu, Y., Liu, C., \& Song, J. (2018). Effects of different drying methods on quality, bacterial viability and storage stability of probiotic enriched apple snacks. Journal of Integrative Agriculture, 17(1), 247255.

Dagci, H. (2002) Protozoon infections and intestinal permeability, Acta Tropica, Volume 81, Issue 1, 1-5.

De Keersmaecker, S. C. J., Verhoeven, T. L. A., Desair, J., Marchal, K., Vanderleyden, J., \& Nagy, I. (2006). Strong antimicrobial activity of Lactobacillus rhamnosus GG against Salmonella typhimurium is due to accumulation of lactic acid. FEMS Microbiology Letters, 259(1), 89-96.

De Moreno de LeBlanc, A., del Carmen, S., Zurita-Turk, M., Santos Rocha, C., van de Guchte, M., Azevedo, V., \& LeBlanc, J. G. (2011). Importance of IL10 modulation by probiotic microorganisms in gastrointestinal inflammatory diseases. ISRN Gastroenterology, 2011, 1-11

Derrien, M., Van Baarlen, P., Hooiveld, G., Norin, E., Müller, M., \& de Vos, W. M. (2011). Modulation of Mucosal Immune Response, Tolerance, and Proliferation in Mice Colonized by the Mucin-Degrader Akkermansia muciniphila. Frontiers in Microbiology, 2.
Desmond, C., Stanton, C., Fitzgerald, G. F., Collins, K., \& Ross, R. P. (2002).Environmental adaptation of probiotic lactobacilli towards improvement of performance during spray drying. International Dairy Journal, 12, 183-190.

Dianawati, D., Mishra, V., \& Shah, N. P. (2013). Survival of Bifidobacterium longum 1941 microencapsulated with proteins and sugars after freezing and freeze drying. Food Research International, 51(2), 503-509.

Dianawati, D., Mishra, V., \& Shah, N. P. (2016). Viability, Acid and Bile Tolerance of Spray Dried Probiotic Bacteria and Some Commercial Probiotic Supplement Products Kept at Room Temperature. Journal of Food Science, 81(6), M1472-M1479.

Eckert, C., Serpa, V. G., dos Santos, A. C. F., da Costa, S. M., Dalpubel, V., Lehn, D. N., \& de Souza, C. F. V. (2017). Microencapsulation of Lactobacillus plantarum ATCC 8014 through spray drying and using dairy whey as wall materials. LWT-Food Science and Technology, 82, 176-183.

Eckmann, L. (2003). Mucosal defences against Giardia. Parasite Immunology, 25(5), 259-270.

Efiuvwevwere, B. J. O., Gorris, L. G. M., Smid, E. J., \& Kets, E. P. W. (1999).

Mannitol-enhanced survival of

Lactococcus lactis subjected to drying. En el sexto simposio de bacterias ácido lácticas, genética, metabolismo y aplicaciones (Lactic acid bacteria, genetics, metabolism and applications), 19-23 Septiembre, 1999, en Veldhoven (Paises Bajos).

El Baaboua, A., El Maadoudi, M., Bouyahya, A., Belmehdi, O., Kounnoun, A., Zahli, R., \& Abrini, J. (2018). Evaluation of antimicrobial activity of four organic acids used in chicks feed to control Salmonella typhimurium: 
Suggestion of amendment in the search standard. International Journal of Microbiology, 1-9.

Elversson, J., \& Millqvist-Fureby, A. (2005). Particle Size and Density in Spray Drying - Effects of Carbohydrate Properties. Journal of Pharmaceutical Sciences, 94(9), 2049-2060.

Faber, F. \& Bäumler, A.J. (2014). The impact of intestinal inflammation on the nutritional environment of the gut microbiota. Immunol Lett 162, 48 -53

FAO/WHO (2002). Guidelines for the Evaluation of Probiotics in Food.

Disponible en:

http://www.who.int/foodsafety/fs_manag ement/en/probiotic_guidelines.pdf

Fernández de Palencia, P., López, P., Corbí, A. L., Peláez, C., \& Requena, T. (2008). Probiotic strains: survival under simulated gastrointestinal conditions, in vitro adhesion to Caco-2 cells and effect on cytokine secretion. European Food Research and Technology, 227(5), 14751484.

Ferreira V, Soares V, Santos C, Silva J, Gibbs P A and Teixeira P (2005) Survival of Lactobacillus sakei during heating, drying and storage in the dried state when growth occurred in the presence of sucrose or monosodium glutamate. Biotechnology Letters 27 249- 252.

Finkelman, F. D., Shea-Donohue, T., Goldhill, J., Sullivan, C. A., Morris, S. C., Madden, K. B. \& Urban, J. F. (1997). Cytokine regulation of host defense against parasitic gastrointestinal nematodes:lessons from studies with rodent models. Annual Review of Immunology, 15(1), 505-533.

Fisher, B. S., Estraño, C. E., \& Cole, J. A. (2013). Modeling Long-Term Host Cell-Giardia lamblia Interactions in an In Vitro Co-Culture System. PLoS ONE, 8(12), e81104.
Fooks, L. J., \& Gibson, G. R. (2002).

Probiotics as modulators of the gut flora. British Journal of Nutrition, 88(S1), s39.

Fooks, L. J., \& Gibson, G. R. (2002). In vitro investigation of the effect of probiotics and prebiotics on selected human intestinal pathogens. FEMS microbiology ecology. 39. 67-75.

Fooks, L. J., \& Gibson, G. R. (2003). Mixed culture fermentation studies on the effects of synbiotics on the human intestinal pathogens Campylobacter jejuni and Escherichia coli. Anaerobe, 9(5), 231-242.

Fu, W. and Etzel, M. R. (1995), Spray Drying of Lactococcus lactis ssp. lactis C2 and Cellular Injury. Journal of Food Science, 60: 195-200.

Furuse, M., Hirase, T., Itoh, M., Nagafuchi, A., Yonemura, S., Tsukita, Sa. \& Tsukita Sh.(1993). Occludin: a novel integral membrane protein localizing at tight junctions. J.Cell Biol. 123:1777-1788.

Furuse, M., Hata, M., Furuse, K., Yoshida, Y., Haratake, A., Sugitani, Y., Noda, T., Kubo,A. \& Tsukita, S. (2002). Claudin-based tight junctions are crucial for the mammalian epidermal barrier. The Journal of Cell Biology, 156(6), 10991111.

Gabriel, K.R. (1971). The biplot graphic display of matrices with application to principal component analysis. Biometrika, 58 (3), 453-467

Gallardo,M.; Gaggiotti, M.; Abdala, A.; Leva, P.; Maciel, M.; Charlón, V.; Cuatrin, A.\& Quaino, O.(2001). Utilización de permeado de suero como suplemento alternativo al grano de maíz en vacas lecheras bajo condiciones de pastoreo. Anuario INTA. Produccion Animal

Gamba, R. R., De Antoni, G., \& León Peláez, A. (2016). Whey permeate fermented with kefir grains shows 
antifungal effect against Fusarium graminearum. Journal of Dairy Research, 83(2), 249-255.

Gamba, R. R.; Moure,M. C.; Diosma, G.; Giannuzzi, L. \& de Antoni, G. L.(2016)

Application of whey permeate fermented with kefir grains for the shelf-life improvement of food and feed; Advances in Microbiology; 6; 9; 1-12.

Gardiner, G. E., O’Sullivan, E., Kelly, J., Auty, M. A. E., Fitzgerald, G. F., Collins, J. K., Ross, R. P., \& Stanton, C. (2000). Comparative survival rates of humanderived probiotic Lactobacillus paracasei and L-salivarius strains during heat treatment and spray drying. Applied and Environmental Microbiology.66:26052612

Gardner, T. B., \& Hill, D. R. (2001). Treatment of Giardiasis. Clinical Microbiology Reviews, 14(1), 114-128.

Garre, E., Raginel, F., Palacios, A., Julien, A., \& Matallana, E. (2010). Oxidative stress responses and lipid peroxidation damage are induced during dehydration in the production of dry active wine yeasts. International Journal of Food Microbiology, 136(3), 295-303.

Garrote, G. L., Abraham, A. G., \& De Antoni, G. L. (2000). Inhibitory Power of Kefir: The Role of Organic Acids. Journal of Food Protection, 63(3), 364369.

Garrote, G. L., Abraham, A. G., \& De Antoni, G. L. (2001). Chemical and microbiological characterization of kefir grains. Journal of Dairy Research, 68, 639-652.

Garrote, G. L., Abraham, A. G., \& De Antoni, G. L. (2010). Microbial interactions in kefir: A natural probiotic drink. En Biotechnology of Lactic Acid Bacteria (pp. 327-340). Editores: Mozzi, F., Raya, R. \& Vignolo, G.M.Ames, IO: Wiley-Blackwell.
Garvey, C. J., Lenné, T., Koster, K. L., Kent, B., \& Bryant, G. (2013).

Phospholipid membrane protection by sugar molecules during dehydrationinsights into molecular mechanisms using scattering techniques. International journal of molecular sciences, 14(4), 8148-8163.

Ghandi A., Powell I., Chen X.D. \& Adhikari B. (2012). Drying kinetics and survival studies of dairy fermentation bacteria in convective air drying environment using single droplet drying. Journal of Food Engineering. 110(3):405-417.

Ghorbani-Choboghlo, H., Zahraei-Salehi, T., Ashrafi-Helan, J., Yahyaraeyat, R., Pourjafar, H., Nikaein, D., Balal, A., \& Ali-Reza Khosravi, A-R. (2015). Microencapsulation of Saccharomyces cerevisiae and its evaluation to protect in simulated gastric conditions. Iran J Microbiology; 7(6): 338-342.

Golman B. \& Julklang W. (2014). Study on spray drying for the production of high value particles. 21st International Congress of Chemical and Process Engineering, CHISA 2014 and 17th Conference on Process Integration, Modelling and Optimisation for Energy Saving and Pollution Reduction, PRES 2014, 4 .

Golovina, E.A.; Golovin, A.; Hoekstra F.A. \& Faller, R. (2009). Water replacement hypothesis in atomic detailfactors determining the structure of dehydrated bilayer stacks. Biophys J, 97, 490-499.

Golowczyc, M., Silva, J., Abraham, A., De Antoni, G., \& Teixeira, P. (2010). Preservation of probiotic strains isolated from kefir by spray drying. Letters in Applied Microbiology, 50, 7-12.

Golowczyc, M.; Gerez, C.L.; Silva, J.; Abraham, A. G.; de Antoni, G. L. (2011) Survival of spray-dried Lactobacillus kefiri is affected by different protectants 
and storage conditions; Biotechnology Letters; 33; 4; 681-686

Golowczyc, M., Vera, C., Santos, M., Guerrero, C., Carasi, P., Illanes, A., et al. (2013). Use of whey permeate containing in situ synthesised galactooligosaccharides for the growth and preservation of Lactobacillus plantarum. Journal of Dairy Research, 80, 374-381.

Golowczyc, M. A., Gugliada, M. J., Hollmann, A., Delfederico, L., Garrote, G. L., Abraham, A. G.,De Antoni, G. (2008). Characterization of homofermentative lactobacilli isolated from kefir grains: potential use as probiotic. Journal of Dairy Research, 75(02).

Golowczyc, M., Mobili, P.; Garrote, G. L., Abraham, A. G., \& De Antoni, G. L. (2007) Protective action of Lactobacillus kefiri carrying S-layer protein against Salmonella enterica serovar Enteritidis. International Journal Of Food Microbiology; vol. 118 p. $264-273$

Granados, C. E., Reveiz, L., Uribe, L. G., \& Criollo, C. P. (2012). Drugs for treating giardiasis. Cochrane Database of Systematic Reviews.

Grasmeijer, N.; Stankovic, M. \& Frinjlink, H.W. (2013) Unraveling protein stabilization mechanisms: vitrification and water replacement in a glass transition temperature controlled system. Biochimica et Biophysica Acta 2013, 1834(4): 763-769

Grimoud,J., Durand, H., Courtin, C., Monsan, P., Ouarné, F., Theodorou, V., \& Roques, C. (2010). In vitro screening of probiotic lactic acid bacteria and prebiotic glucooligosaccharides to select effective synbiotics. Anaerobe, 16(5), 493-500.

Grit, G.H.; Devriendt, B. \& Van Coppernolle, S. (2014). Giardia duodenalis stimulates partial maturation of bovine dendritic cells associated with altered cytokine secretion and induction of T-cell proliferation. Parasite Immunol;36: 157-169

Groschwitz, K. R., \& Hogan, S. P. (2009). Intestinal barrier function: Molecular regulation and disease pathogenesis. Journal of Allergy and Clinical Immunology, 124(1), 3-20.

Guandalini S., Pensabene L., Zikri M. A., Dias J. A., Casali L. G., Hoekstra H., Kolacek S., Massar K. Micetic-Turk D., Papadopoulou A., Salazar de Sousa J., Sandhu B. Szajewska H. y Weizman Z. (2000). Lactobacillus $G G$ administered in oral rehydration solution to children with acute diarrhea: a multicenter European trial. Journal of Pediatric Gastroenterology and Nutrition. 30 (1): 54-60.

Gul, O., Mortas, M., Atalar, I., Dervisoglu, M., \& Kahyaoglu, T. (2015). Manufacture and characterization of kefir made from cow and buffalo milk, using kefir grain and starter culture. Journal of Dairy Science, 98(3), 1517-1525.

Gupta, N., Agarwal, A.K., Katiyar, S.K., Chandra, K., Sharma, A., Rastogi, A.K. \& Das, S.R.(1989). Virulence of Giardia lamblia: an in vitro study on host-parasite interaction. Indian J Exp

Biol.;27(11):983-6.

Güzel-Seydim, Z. B., Seydim, A. C., Greene, A. K., \& Bodine, A. B. (2000). Determination of organic acids and volatile flavor substances in kefir during fermentation. Journal of Food Composition and Analysis, 13(1), 35-43.

Halliez, M.C.M.; LeGoff, L.; Francois, A.; Colasse, E.; Gargala, G. \& Villena, I. (2014). Novel insights in post-infectious irritable bowel syndrome in experimental giardiasis. FASEB J.;28(1):650.65

Hansen, E. (2002). Commercial bacterial starter cultures for fermented foods of the future. International Journal of Food Microbiology, 78 (1-2), 119-131. 
Hill, D. R., Guerrant, R. L., Pearson, R. D., \& Hewlett, E. L. (1983). Giardia lamblia Infection of Suckling Mice. Journal of Infectious Diseases, 147(2), 217-221.

Harrington, L. E., Hatton, R. D., Mangan, P. R., Turner, H., Murphy, T. L., Murphy, K. M., \& Weaver, C. T. (2005). Interleukin 17-producing CD4+ effector $T$ cells develop via a lineage distinct from the T helper type 1 and 2 lineages. Nature Immunology, 6(11), 1123-1132.

Heidebach, T., Forst, P. \& Kulozik, U. (2009) Microencapsulation of probiotic cells by means of rennet-gelation of milk proteins. Food Hydrocolloid. 23(7),16701677.

Hill, C., Guarner, F., Reid, G., Gibson, G. R., Merenstein, D. J., Pot, B. \& Sanders, M. E. (2014). The International Scientific Association for Probiotics and Prebiotics consensus statement on the scope and appropriate use of the term probiotic. Nature Reviews Gastroenterology \& Hepatology, 11(8), 506-514.

Hold, G. L. (2014). Role of the gut microbiota in inflammatory bowel disease pathogenesis: What have we learnt in the past 10 years? World Journal of Gastroenterology, 20(5), 1192.

Huang, S., Gaucher, F., Cauty, C., Jardin, J., Le Loir, Y., Jeantet, R. \& Jan, G. (2018). Growth in hyper-concentrated sweet whey triggers multi stress tolerance and spray drying survival in Lactobacillus casei BL23: from the molecular basis to new perspectives for sustainable probiotic production.

Frontiers in Microbiology, 9.

Huang, S., Méjean, S., Rabah, H., Dolivet, A., Le Loir, Y. \& Chen, X. D (2017). Double use of concentrated sweet whey for growth and spray drying of probiotics: Towards maximal viability in pilot scale spray dryer. Journal of Food Engineering, 196,11-17.
Huang, S., Vignolles, M. L., Chen, X. D., Le Loir, Y., Jan, G., Schuck, P., \& Jeantet, R. (2017). Spray drying of probiotics and other food-grade bacteria: A review. Trends in Food Science \& Technology, 63, 1-17.

Huang, S., Yang, Y., Fu, N., Qin, Q., Zhang, L., \& Chen, X. D. (2014). Calcium-Aggregated Milk: a Potential New Option for Improving the Viability of Lactic Acid Bacteria under Heat Stress. Food and Bioprocess Technology, 7(11), 3147-3155.

Hugo, A., Kakisu, E., De Antoni, G. L., \& Pérez, P. F. (2008). Lactobacilli antagonize biological effects of enterohaemorrhagic Escherichia coli in vitro. Letters in Applied Microbiology, 46(6), 613-619.

Hugo, A., Bruno, F., \& Golowczyc, M. A. (2016). Whey permeate containing galactooligosaccharides as a medium for biomass production and spray drying of Lactobacillus plantarum CIDCA 83114. LWT - Food Science and Technology, 69, 185-190.

Humen, M. A., De Antoni, G. L., Benyacoub, J., Costas, M. E., Cardozo, M. I., Kozubsky, L., Saudan, K.Y., Boenzli-Bruand, A., Blum, S., Schiffrin, E.J., \& Perez, P. F. (2005). Lactobacillus johnsonii La1 Antagonizes Giardia intestinalis In Vivo. Infection and Immunity, 73(2), 1265-1269.

Humen, M. (2009). Interacción de Giardia intestinalis con el hospedador. Efecto antagónico de probióticos intestinales. Tesis Doctoral. UNLP

Humen M. A., Pérez P. F. \& Liévin-Le Moal V. (2011). Lipid raft-dependent adhesion of Giardia intestinalis trophozoites to a cultured human enterocyte-like Caco-2/TC7 cell monolayer leads to cytoskeletondependent functional injuries. Cell. Microbiol. 13, 1683-1702. 
Ilango, S., Pandey, R., \& Antony, U. (2016). Functional characterization and microencapsulation of probiotic bacteria from koozh. Journal of Food Science and Technology, 53(2), 977-989.

Iraporda, C., Júnior, M. A., Neumann, E., Nunes, Á. C., Nicoli, J. R., Abraham, A. G., \& Garrote, G. L. (2017). Biological activity of the non-microbial fraction of kefir: Antagonism against intestinal pathogens. Journal of Dairy Research, 84(3), 339-345.

Isolauri E., Sütas Y., Kankaanpää P., Arvilommi H. \& Salminen S. (2001). Probiotics: effects on immunity. The Journal of Clinical Nutrition. 73: 444-450

Janning, B., \& in'T Veld, P. H. (1994). Susceptibility of bacterial strains to desiccation: a simple method to test their stability in microbiological reference materials. Analytica Chimica Acta,286, 469-476.

Jantzen, M. , Göpel, A. and Beermann, C. (2013), Direct spray drying and microencapsulation of probiotic Lactobacillus reuteri from slurry fermentation with whey. J Appl Microbiol, 115: 1029-1036.

Jung, H. C., Eckmann, L., Yang, S. K., Panja, A., Fierer, J. \& MorzyckaWroblewska,E.(1995). A distinct array of proinflammatory cytokines is expressed inhuman colon epithelial cells in response to bacterial invasion. J. Clin. Invest.95,55-65.

Kakisu, E., Abraham, A. G., Tironi Farinati, C., Ibarra, C., \& De Antoni, G. L. (2012). Lactobacillus plantarum isolated from kefir protects vero cells from cytotoxicity by type-II shiga toxin from Escherichia coli O157:H7. Journal of Dairy Research, 80(01), 64-71.

Kakisu, E., Bolla, P., Abraham, A. G., de Urraza, P., \& De Antoni, G. L. (2013). Lactobacillus plantarum isolated from kefir: Protection of cultured Hep-2 cells against Shigella invasion. International Dairy Journal, 33(1), 22-26.

Khem, S., Bansal, V., Small, D. M., \& May, B. K. (2016). Comparative influence of $\mathrm{pH}$ and heat on whey protein isolate in protecting Lactobacillus plantarum A17 during spray drying. Food Hydrocolloids, 54, 162-169.

Kim, D.-H., Jeong, D., Kim, H., Kang, I.B., Chon, J.-W., Song, K.-Y., \& Seo, K.H. (2016). Antimicrobial Activity of Kefir against Various Food Pathogens and Spoilage Bacteria. Korean Journal for Food Science of Animal Resources, 36(6), 787-790.

Kitazawa H., Ueha S., Itoh S., Watanabe H., Konno K., Kawai Y., Saito T., Itoh T. \& Yamaguchi T. (2001). AT oligonucleotides inducing B lymphocyte activation exist in probiotic Lactobacillus gasseri. International Journal of Food Microbiology. 65 (3): 149-62.

Kopp-Hoolihan L. (2001). Prophylactic and therapeutic uses of probiotics: A review. Journal of the American Dietetic Association. 101(2): 229-238.

Kuitunen, M., Kukkonen, K., JuntunenBackman, K., Korpela, R., Poussa, T., Tuure, T. \& Savilahti, E. (2009). Probiotics prevent IgE-associated allergy until age 5 years in cesarean-delivered children but not in the total cohort. Journal of Allergy and Clinical Immunology, 123(2), 335-341.

Lapsiri, W.; Bhandari, B. \& Wanchaitanawong, P. (2012) Viability of Lactobacillus plantarum TISTR 2075 in Different Protectants during Spray Drying and Storage, Drying Technology, 30:13, 1407-1412.

Lavari, L., Páez, R., Cuatrin, A., Reinheimer, J., \& Vinderola, G. (2014). Use of cheese whey for biomass production and spray drying of probiotic lactobacilli. Journal of Dairy Research, 81(3), 267-274. 
Leite, A. M. O., Leite, D. C. A., Del Aguila, E. M., Alvares, T. S., Peixoto, R. S., Miguel, M. A. L., \& Paschoalin, V. M. F. (2013). Microbiological and chemical characteristics of brazilian kefir during fermentation and storage processes. Journal of Dairy Science, 96(7), 4149-4159

Leite, A. M. O., Miguel, M. A., Peixoto, R. S., Rosado, A. S., Silva, J. T., \& Paschoalin, V. M. (2013).

Microbiological, technological and therapeutic properties of kefir: a natural probiotic beverage. Brazilian journal of microbiology, 44(2), 341-349.

Leja K., Dembczyński R., Białas W. \& Jankowski T. (2009). Production of dry Lactobacillus rhamnosus GG preparations by spray drying and lyophilization in aqueous two-phase systems. Acta Sci.Pol. Technol. Aliment. 8 (4), 39-49

León Pelaez, A.M. (2013) Estudio de la capacidad de los microorganismos de kefir para inhibir el desarrollo fúngico y para secuestrar micotoxinas. Tesis Doctoral. UNLP

Leslie, S. B.; Israeli, E.; Lighthart, B.; Crowe, J. H. \& Crowe, L. M. (1995). Trehalose and sucrose protect both membranes and proteins in intact bacteria during drying. Journal of Applied and Environmental Microbiology, 61 (10), 3592-3597.

Leung, J. M., Graham, A. L., \& Knowles, S. C. L. (2018). Parasite-Microbiota interactions with the vertebrate gut: Synthesis Through an Ecological Lens. Frontiers in Microbiology, 9.

Li, E., Zhou, P., Petrin, Z. \& Singer, S.M. (2004). Mast Cell-Dependent Control of Giardia lamblia Infections in Mice. Infect. Immun. 72, 6642-6649.

Lian, W. (2002). Survival of bifidobacteria after spray-drying.
International Journal of Food Microbiology, 74(1-2), 79-86.

Linders L. J. M., de Jong G. I. W., Meerdink G. \& van't Riet K. (1997). Carbohydrates and the dehydration inactivation of Lactobacillus plantarum: The role of moisture distribution and water activity. Journal of Food Engineering, 31, 237-250.

Londero, A; Iraporda, C.; G. L., Garrote, G. L., \& Abraham, A. G (2014) Cheese whey fermented with kefir microorganisms: Antagonism against Salmonella and immunomodulatory capacity. International Journal Of Dairy Technology vol. 68 p. $118-126$

Londero, A., Hamet, M. F., DeAntoni, G. L., Garrote, G. L., \& Abraham, A. G. (2012). Kefir grains as a starter for whey fermentation at different temperatures: Chemical and microbiological characterisation. Journal of Dairy Research, 79, 262-271.

Lopez-Romero, G., Quintero, J., Astiazarán-García, H. \& Velazquez, C.(2015) Host defences against Giardia lamblia. Parasite Immunol.;37(8):394406

Madara, J. L. (1987). Intestinal absorptive cell tight junctions are linked to cytoskeleton. American Journal of Physiology-Cell Physiology, 253(1), C171-C175.

Magalhães, K. T., Pereira, M. A., Nicolau, A., Dragone, G., Domingues, L., Teixeira, J. A., \& Schwan, R. F. (2010). Production of fermented cheese wheybased beverage using kefir grains as starter culture: Evaluation of morphological and microbial variations. Bioresource Technology, 101(22), 88438850 .

Magne, D., Favennec, L., Chochillon, C., Gorenflot, A., Meillet, D., Kapel, N. \& Gobert, J. G. (1991). Role of cytoskeleton and surface lectins in 
Giardia duodenalis attachment to $\mathrm{Caco} 2$ cells. Parasitology Research, 77(8), 659662.

Maki, R., Matsukawa, M., Matsuduka, A., Hashinaga, M., Anai, H., Yamaoka, Y., \& Fujii, C. (2017). Therapeutic effect of lyophilized, Kefir-fermented milk on constipation among persons with mental and physical disabilities. Japan Journal of Nursing Science, 15(3), 218-225.

Maldonado Galdeano, C., Cazorla, S. I., Lemme Dumit, J. M., Vélez, E., \& Perdigón, G. (2019). Beneficial effects of probiotic consumption on the immune system. Annals of Nutrition and Metabolism, 115-124.

Maldonado -Galdeano, C., Núñez, I. N., de Moreno de LeBlanc, A., Carmuega, E., Weill, R., \& Perdigón, G. (2011). Impact of a probiotic fermented milk in the gut ecosystem and in the systemic immunity using a non-severe proteinenergy-malnutrition model in mice. BMC Gastroenterology, 11(1).

Mani-López, E., García, H. S., \& LópezMalo, A. (2012). Organic acids as antimicrobials to control Salmonella in meat and poultry products. Food Research International, 45(2), 713-721.

Marquina D, Santos A, Corpas I,et al. (2002) Dietary influence of kefir on microbial activities in the mouse bowel.Lett Appl Microbiol 35, 136-140.

Masters, K. (1985).Spray drying handbook, (4th ed., 1991). London: Halsted Press.

Mathlouthi, M. (2001). Water content, water activity, water structure and the stability of foodstuffs. Food Control, 12 (2001), pp. 409-417

Mauriello, G., Aponte, M., Andolfi, R., Moschetti, G., \& Villani, F.(1999). Spray-drying of bacteriocin-producing lactic acid bacteria. Journal of Food Protection. 62, 773-777.

Meng, X. C., Stanton, C., Fitzgerald, G. F., Daly, C., \& Ross, R. P. (2008). Anhydrobiotics: The challenges of drying probiotic cultures. Food Chemistry, 106(4), 1406-1416.

Menshutina, N. V., Gordienko, M. G., Voinovskiy, A. A., \& Zbicinski, I. (2010). Spray Drying of Probiotics: Process Development and Scale-Up. Drying Technology, 28(10), 1170-1177.

Metchnikoff, E. (1907). Lactic acid as inhibiting intestinal putrefaction. En: The prolongation of life: Optimistic studies. W. Heinemann, London. pp. 161-183.

Mikołajczyk, A. \& Radkowski, M. (2002) Elimination of Salmonella spp. by lactic acid. Polish Journal of Veterinary Science; 5(3):139-143.

Millqvist-Fureby, A., Malmsten, M. \& Bergenståhl, B. (2000). An Aqueous Polymer Two-Phase System as Carrier in the Spray-Drying of Biological Material. Journal of colloid and interface science. 225. 54-61.

Morgan, C. A., Herman, N., White, P. A., $\&$ Vesey, G. (2006). Preservation of micro-organisms by drying; a review. Journal of Microbiological Methods, 66, 183-193.

Müller, N., \& von Allmen, N. (2005).

Recent insights into the mucosal reactions associated with Giardia lamblia infections. International Journal for Parasitology, 35(13), 1339-1347.

Muset, G.B. \& Castells, M.L. (2017)

Valorización del lactosuero. INTI (Instituto Nacional de Tecnología Industrial). 1ra Ed. ISBN: 978-950-532$341-8$

Nagata, Y., Hashiguchi, K., Kamimura, Y., Yoshida, M., \& Gomyo, T. (2009). The gastrointestinal transit tolerance of Lactobacillus plantarum strain no. 14 
depend on carbon source. Bioscience, Biotechnology, and Biochemistry, 73, 2650-2655.

Nguyen, T. L. A., Vieira-Silva, S., Liston, A., \& Raes, J. (2015). How informative is the mouse for human gut microbiota research: Disease Models \& Mechanisms, 8(1), 1-16.

Niamah, A., Al-Manhel, A. \& Alsahlany, S. (2018). Effect of microencapsulation of Saccharomyces boulardii on viability of yeast in vitro and ice cream. Carpathian J. Food Science and Technology. Vol. 10, 111-118

O'Hara, J.R. \& Buret, A.G. (2008). Mechanisms of intestinal tight junctional disruption during infection. Front Biosci.; 13:7008-21

Olson, M.E., McAllister, T.A. \& Deselliers, L., (1995). Effects of giardiasis on production in a domestic ruminant (lamb) model. Am. J. Vet. Res. $56,1470-1474$.

Otles S. y Cagindi O. (2003). Kefir: A probiotic dairy-composition, nutritional and therapeutic aspects. Pakistan Journal of Nutrition. 2 (2): 54-59

Páez, R., Lavari, L., Audero, G., Cuatrin, A., Zaritzky, N., Reinheimer, J., \& Vinderola, G. (2013). Study of the effects of spray-drying on the functionality of probiotic lactobacilli. International Journal of Dairy Technology, 66(2), 155161.

Panaro, M.A., Cianciulli, A., Mitolo, V., Acquafreda, A., Brandonisio, O. \& Cavallo, P.(2007) Caspase-dependent apoptosis of the HCT-8 epithelial cell line induced by the parasite Giardia intestinalis. FEMS Immunol Med Microbiol.;51(2):302-9.

Parashar, A., Jin, Y., Mason, B., Chae, M., \& Bressler, D. C. (2016). Incorporation of whey permeate, a dairy effluent, in ethanol fermentation to provide a zero waste solution for the dairy industry. Journal of Dairy Science, 99(3), 1859-1867.

Park, H., Li, Z., Yang, X. O., Chang, S. H., Nurieva, R., Wang, Y.-H., \& Dong, C. (2005). A distinct lineage of CD4 T cells regulates tissue inflammation by producing interleukin 17. Nature Immunology, 6(11), 1133-1141.

Pavlaseck, I.; Hess, L., \& Stehlik, I. (1995). The first detection of Giardia spp. In horses in the Czech Republic. Veterinariya Meditsina (Praha), 40, 8186.

Peighambardoust, S. H., Golshan Tafti, A., \& Hesari, J. (2011). Application of spray drying for preservation of lactic acid starter cultures: A review. Trends in Food Science \& Technology, 22(5), 215224.

Pentewar, R. S., Somwanshi, S. V., \& Sugave, B. K. (2014). Spray drying: A review on single step rapid drying technique. Research Journal of Pharmaceutical, Biological and Chemical Sciences, 5(2), 1502-1514.

Perdana, J., Bereschenko, L., Fox, M.B., Kuperus, J.H., Kleerebezem, M., Boom, R.M., \& Schutyseral, M.A.I. (2013). Dehydration and thermal inactivation of Lactobacillus plantarum WCFS1: Comparing single droplet drying to spray and freeze drying. Food Research International. 54, 1351-1359

Perdana, J., Fox, M. B., Siwei, C., Boom, R. M., \& Schutyser, M. A. I. (2014). Interactions between formulation and spray drying conditions related to survival of Lactobacillus plantarum WCFS1. Food Research International, 56, 9-17.

Perez, P. F., Minnaard, J., Rouvet, M., Knabenhans, C., Brassart, D., De Antoni, G. L., \& Schiffrin, E. J. (2001). Inhibition of Giardia intestinalis by Extracellular Factors from Lactobacilli: an In Vitro 
Study. Applied and Environmental Microbiology, 67(11), 5037-5042.

Prado, M. R., Blandón, L. M., Vandenberghe, L. P. S., Rodrigues, C., Castro, G. R., Thomaz Soccol, V., \& Soccol, C. R. (2015). Milk kefir: Composition, microbial cultures, biological activities, and related products. Frontiers in Microbiology, 6, 1177.

Rahman, M. S. (2010). Food stability determination by macro-micro region concept in the state diagram and by defining a critical temperature. Journal of Food Engineering, 99(4), 402-416.

Rao, R. K., \& Samak, G. (2013). Protection and Restitution of Gut Barrier by Probiotics: Nutritional and Clinical Implications. Current nutrition and food science, 9(2), 99-107.

Reddy, K. B. P. K., Madhu, A. N., \& Prupella, S. G. (2009). Comparative survival and evaluation of functional properties of spray dried lactic acid bacteria. International Journal of Dairy Technology, 62, 240-248.

Resta-Lenert, S., \& Barrett, K. E. (2006). Probiotics and commensals reverse TNF$\alpha-$ and IFN- $\gamma$-induced dysfunction in human intestinal epithelial cells. Gastroenterology, 130(3), 731-746.

Riveros,B., Ferrer,J.

\&Borquez,R.(2009).Spray drying of a vaginal probiotic strain of Lactobacillus acidophilus. Drying Technology. 27, 123-132.

Roberts R., Moreno G., Bottero D., Gaillard M.E., Fingermann M., Graieb A., Rumbo M. y Hozbor D. 2008. Outer membrane vesicles as a cellular vaccine against pertussis. Vaccine. 26(36):46394646.

Rodríguez-Fuentes, G. B., CedilloRivera, R., Fonseca-Liñán, R., ArgüelloGarcía, R., Muñoz, O., Ortega-Pierres, G., \& Yépez-Mulia, L. (2006). Giardia duodenalis: analysis of secreted proteases upon trophozoite-epithelial cell interaction in vitro. Memórias Do Instituto Oswaldo Cruz, 101(6), 693-696.

Rodríguez-Hernández, J., Canut-Blasco, A., \& Martín-Sánchez, A. M. (1996). Seasonal prevalences of Cryptosporidium and Giardia infections in children attending day care centres in Salamanca (Spain) studied for a period of 15 months. European Journal of Epidemiology, 12(3), 291-295.

Roelans, E. \& Taeymans, D. (1990). Effect of drying conditions on survival and enzyme activity of microorganisms. Engineering and food Vol.3: advanced processes. 559-569.

Rogers, L. A. (1914). The preparation of dried cultures. J. Infect. Dis. 14:100

Rolny, I. S., Minnaard, J., Racedo, S. M., \& Perez, P. F. (2014). Murine model of Bacillus cereus gastrointestinal infection. Journal of Medical Microbiology, 63(Pt_12), 1741-1749.

Romagnani, S. (1997). The Th1/Th2 paradigm. Immunology Today, 18(6), 263-266.

Romano, A., Blaiotta, G., Di Cerbo, A., Coppola, R., Masi, P., \& Aponte, M. (2014). Spray-dried chestnut extract containing Lactobacillus rhamnosus cells as novel ingredient for a probiotic chestnut mousse. Journal of Applied Microbiology, 116(6), 1632-1641.

Rosa, D. D., Dias, M. M. S., Grześkowiak, Ł. M., Reis, S. A., Conceição, L. L., \& Peluzio, M. do C. G. (2017). Milk kefir: nutritional, microbiological and health benefits. Nutrition Research Reviews, 30(01), 8296.

Rosenfeldt V., Benfeldt E., Valerius N. H., Paerregaard A. y Michaelsen K. F. (2004). Effect of probiotics on gastrointestinal symptoms and small intestinal permeability in children with 
atopic dermatitis. The Journal of Pediatrics. 145 (5): 612-616.

Rubin, H. E., Nerad, T. \& Vaughan, F. (1982). Lactate acid inhibition of Salmonella typhimurium in yogurt. J. Dairy Sci.65:197-203

Rumbo, M., Sierro, F., Debard, N., Kraehenbuhl, J.-P., \& Finke, D. (2004). Lymphotoxin $\beta$ receptor signaling induces the chemokine CCL20 in intestinal epithelium. Gastroenterology, 127(1), 213-223.

Saarela, M., Virkajarvi, I., Alakomi, H.L., Mattila-Sandholm, T., Vaari, A., Suomalainen, T., \& Matto, J. (2005). Influence of fermentation time, cryoprotectant and neutralization of cell concentrate on freeze-drying survival, storage stability, and acid and bile exposure of Bifidobacterium animalis ssp. lactis cells produced without milkbased ingredients. Journal of Applied Microbiology, 99(6), 1330-1339.

Saghaug, C.S.; Sørnes, S.; Peirasmaki, D.; Svärd, S.; Langeland, N. \& Hanevik, K. (2016). Human memory CD4T cell immune responses against Giardia lamblia. Clin Vaccine Immunol23:11-18.

Salva, S., Villena, J., \& Alvarez, S. (2010). Immunomodulatory activity of Lactobacillus rhamnosus strains isolated from goat milk: Impact on intestinal and respiratory infections. International Journal of Food Microbiology, 141(1-2), 82-89.

Salva, S., Merino, M. C., Agüero, G., Gruppi, A., \& Alvarez, S. (2012). Dietary Supplementation with Probiotics Improves Hematopoiesis in Malnourished Mice. PLoS ONE, 7(2), e31171.

Salva, S., Marranzino, G., Villena, J., Agüero, G., \& Alvarez, S. (2014). Probiotic Lactobacillus strains protect against myelosuppression and immunosuppression in cyclophosphamide-treated mice.
International Immunopharmacology, 22(1), 209-221.

Santivarangkna, C., Wenning, M., Foerst, P. \& Kulozik, U. (2007), Damage of cell envelope of Lactobacillus helveticus during vacuum drying. Journal of Applied Microbiology, 102: 748-756.

Santivarangkna, C., Higl, B., \& Foerst, P. (2008). Protection mechanisms of sugars during different stages of preparation process of dried lactic acid starter cultures. Food microbiology. 25, 429441.

Santivarangkna, C., Kulozik, U., \& Foerst, P. (2007). Alternative drying processes for the industrial preservation of lactic acid starter cultures.

Biotechnology Progress, 23, 302e315.

Santivarangkna, C., Kulozik, U., \& Foerst, P. (2008). Inactivation mechanisms of lactic acid starter cultures preserved by drying processes. Journal of Applied Microbiology, 105,1e13.

Savioli, L., Smith, H. \& Thompson, A. (2006). Giardia and Cryptosporidium join the 'Neglected Diseases Initiative'. Trends Parasitol.; 22(5):203- 208

Schaefer, F.W.; Johnson, C.H.; Hsu, C.H. \& Rice, E.W.(1991). Determination of Giardia lamblia cyst infective dose for the Mongolian gerbil (Meriones unguiculatus). Applied and Environmental Microbiology, 57(8):2408-2409.

Schmidt, S. J. (2004). Water and solids mobility in foods. Advances in Food and Nutrition Research, 48,1-101.

Schuck, P. (2002). Spray drying of dairy products: state of the art. Lait,82, 375382.

Schuck, P., Dolivet, A., Méjean, S., Hervé, C., \& Jeantet, R. (2013). Spray drying of dairy bacteria: New opportunities to improve the viability of 
bacteria powders. International Dairy Journal, 31(1), 12-17.

Schutyser, M. A. I., Perdana, J., \& Boom, R. M. (2012). Single droplet drying for optimal spray drying of enzymes and probiotics. Trends in Food Science \& Technology, 27(2), 73-82.

Scott, K. G. E., Meddings, J. B., Kirk, D. R., Lees-Miller, S. P., \& Buret, A. G. (2002). Intestinal infection with Giardia spp. reduces epithelial barrier function in a myosin light chain kinase-dependent fashion. Gastroenterology, 123(4), 11791190.

Scott, K.G.; Yu, L.C. \& Buret, A.G. (2004) Role of CD8+and CD4+T lymphocytes in jejunal mucosal injury during murine giardiasis.

InfectImmun.;72(6):3536-42.

Scott, K.G.; Logan, M.R.; Klamer, G.M.; Teoh, D.A. \& Buret, A.G. (2010). Effectsof Giardia muris infection on jejunal architecture, brush borderultrastructure, disaccharidases and interleukin-6: the role of T-lymphocytes. Infect Immun.; 68(6):3412-8

Serradell, M.C.; Gargantini, P.R.; Saura, A.; Oms, S.R.; Rupil, L.L.; Berod, L.; Sparwasser, T. \& Luján, H.D. (2018). Cytokines, antibodies, and histopathological profiles during Giardia infection and variant-specific surface protein based vaccination. Infect Immun 86:e00773-17.

Servin, A. L. (2004). Antagonistic activities of lactobacilli and bifidobacteria against microbial pathogens. FEMS Microbiology Reviews, 28(4), 405-440.

Sharma, G., \& Im, S.-H. (2018).

Probiotics as a Potential Immunomodulating Pharmabiotics in Allergic Diseases: Current Status and Future Prospects. Allergy, Asthma \& Immunology Research, 10(6), 575.
Sheih Y-H., Chiang B-L., Wang L-H., Liao C-K. \& Gill H. S. (2001). Systemic immunityenhancing effects in healthy subjects following dietary consumption of the lactic acid bacterium Lactobacillus rhamnosus HN001. Journal of the American College of Nutrition. 20 (2): 149-156.

Shin, N.-R., Whon, T. W., \& Bae, J.-W. (2015). Proteobacteria: microbial signature of dysbiosis in gut microbiota. Trends in Biotechnology, 33(9), 496503.

Shokri, S., Ehsani, A., \& Jasour, M. S. (2015). Efficacy of lactoperoxidase system- whey protein coating on shelflife extension of rainbow trout fillets during cold storage $\left(4^{\circ} \mathrm{C}\right)$. Food and Bioprocess Technology, 8( 1), 54-62.

Shukla, G., Devi, P., \& Sehgal, R. (2008). Effect of Lactobacillus casei as a Probiotic on Modulation of Giardiasis. Digestive Diseases and Sciences, 53(10), 2671-2679.

Shukla, G., \& Sidhu, R. K. (2011). Lactobacillus casei as a probiotic in malnourished Giardia lamblia-infected mice: a biochemical and

histopathological study. Canadian Journal of Microbiology, 57(2), 127-135.

Silva, C. F. G. da, Santos, F. L., Santana, L. R. R. de, Silva, M. V. L., \&

Conceição, T. de A. (2018). Development and characterization of a soymilk Kefirbased functional beverage. Food Science and Technology. doi:10.1590/1678457x.10617

Silva, H. L., Balthazar, C. F., Esmerino, E. A., Neto, R. P., Rocha, R. S., Moraes, J., Granato, D. (2018). Partial substitution of $\mathrm{NaCl}$ by $\mathrm{KCl}$ and addition of flavor enhancers on probiotic Prato cheese: A study covering manufacturing, ripening and storage time. Food Chemistry, 248, 192-200. 
Silva J., Carvalho A. S., Ferreira R., Vitorino R., Amado F., Domingues P., Teixeira P. \& Gibbs P. A. (2005). Effect of the $\mathrm{pH}$ of growth on the survival of Lactobacillus delbrueckii spp. bulgaricus to stress conditions during spray-drying. Journal of Applied Microbiology, 98, 775-782.

Silva, J., Carvalho, A. S., Teixeira, P., \& Gibbs, P. A. (2002). Bacteriocin production by spray-dried lactic acid bacteria. Letters in Applied Microbiology, 34(2), 77-81.

Silva, J., Freixo, R., Gibbs, P., \& Teixeira, P. (2011). Spray-drying for the production of dried cultures. International Journal of Dairy Technology, 64(3), 321335.

Simpson, P. J., Stanton, C., Fitzgerald, G. F., \& Ross, R. P. (2005). Intrinsic tolerance of Bifidobacterium species to heat and oxygen and survival following spray drying and storage .Journal of Applied Microbiology, 99, 493-501.

Singer, S. M., \& Nash, T. E. (2000). The Role of Normal Flora in Giardia lamblia Infections in Mice. The Journal of Infectious Diseases, 181(4), 1510-1512.

Singer, S. M., \& Nash, T. E. (2000). Tcell-dependent control of acute Giardia lamblia infections in mice. Infect Immun.; 68: 170-175

Sinkiewicz-Enggren, G.; Skurzynska, A. \& Sandberg, T. (2015) Stabilization of Lactobacillus reuteri by encapsulation of bacterial cells through spray drying. American Journal of BioMedicine;3(7): 432-443

Slavutsky, A. M., Chávez, M. C., Favarotrindade, C. S., \& Bertuzzi, M. A. (2016). Encapsulation of Lactobacillus Acidophilus in a Pilot-Plant Spray-Dryer. Effect of Process Parameters on Cell Viability. Journal of Food Process Engineering, 40(2), e12394.
Smith-Norowitz, T. A. \& Bluth, M. H. (2015). Probiotics and diseases of altered IgE regulation: A short review. Journal of Immunotoxicology, 13(2), 136-140.

Solaymani-Mohammadi, S., \& Singer, S. M. (2011). Host Immunity and Pathogen Strain Contribute to Intestinal Disaccharidase Impairment following Gut Infection. The Journal of Immunology, 187(7), 3769-3775.

Sosnik, A., \& Seremeta, K. P. (2015). Advantages and challenges of the spraydrying technology for the production of pure drug particles and drug-loaded polymeric carriers. Advances in Colloid and Interface Science, 223,40-54.

Soukoulis, C., Behboudi-Jobbehdar, S., Yonekura, L., Parmenter, C., \& Fisk, I. (2013). Impact of Milk Protein Type on the Viability and Storage Stability of Microencapsulated Lactobacillus acidophilus NCIMB 701748 Using Spray Drying. Food and Bioprocess Technology, 7(5), 1255-1268.

Sreenivas, K., Ganguly, N. K., Ghosh, S., Sehgal, R., \& Mahajan, R. C. (1995). Identification of a $148-\mathrm{kDa}$ surface lectin from Giardia lamblia with specificity for $\alpha$-methyl-d-mannoside. FEMS

Microbiology Letters, 134(1), 33-37.

Stadelmann, B., Hanevik, K., Andersson, M.K., Bruserud, O. \& Svard, S.G. (2013). The role of arginine and argininemetabolizing enzymes during Giardiahost cell interactions in vitro. BMC Microbiol.2013;13:256.

Stensvold, C. R., \& van der Giezen, M. (2018). Associations between Gut Microbiota and Common Luminal Intestinal Parasites. Trends in Parasitology, 34(5), 369-377.

Sunny-Roberts, E. O. \& Knorr, D. (2009). The protective effect of monosodium glutamate on survival of Lactobacillus rhamnosus GG and Lactobacillus rhamnosus E-97800 (E800) 
strains during spray-drying and storage in trehalose-containing powders.

International Dairy Journal, 19, 209-214.

Takeda K., Suzuki T., Shimada S. I., Shida K., Nanno M. \& Okumura K. (2006). Interleukin-12 is involved in the enhancement of human natural killer cell activity by Lactobacillus casei Shirota. Clinical and Experimental Immunology. 146 (1): 109-115.

Teixeira, P., Castro, H., \& Kirby, R. (1995). Spray drying as a method forpreparing concentrated cultures of Lactobacillus bulgaricus. Journal of Applied Bacteriology. 78, 456 - 462

Teixeira, P., Castro, H., Malcata, F. X., \& Kirby, R. (1995). Survival of Lactobacillus delbrueckii ssp. bulgaricus following spray drying. Journal of Dairy Science. 78, 1025-1031.

Teixeira, P., Castro, H., Mohacsi-Farkas, C., \& Kirby, R. (1997). Identification of sites of injury in Lactobacillus bulgaricus during heat stress. Journal of Applied Microbiology, 83(2), 219-226.

Thompson, R.C.A., Reynoldson, J.A., Mendis, A.H.W., (1993).Giardia and giardiasis. Adv. Parasitol. 32, 71-160.

Thompson, R.C.A., (1998). Giardia infections. En: Zoonoses: Biology, Clinical Practice and Public Health Control. Editores: Palmer, S.R., Soulsby, E.J.L., Simpson, D.I.H. Oxford University Press, pp. 545-561.

Toro-Sierra, J., Schumann, J., \& Kulozik, U. (2013). Impact of spray-drying conditions on the particle size of microparticulated whey protein fractions. Dairy Science \& Technology, 93(4-5), 487-503.

Torres, M. F., Costa, A. F., Uetanabaro, A. P. T., Farias, 1. M., Penna, F. J., Alves, C. A., \& Vieira, E. C. (2000). Influence of bacteria from the duodenal microbiota of patients with symptomatic giardiasis on the pathogenicity of Giardia duodenalis in gnotoxenic mice. Journal of Medical Microbiology, 49(3), 209215 .

Troeger, H., Eppel, H.J., Schneider, T., Wahnschaffe, U., Ulrich, R. \& Burchard, G.D. (2007). Effect of chronic Giardia lamblia infection on epithelial transport and barrier function in human duodenum. Gut. 2007; 56:328-35.

Umeda, C., Sonoyama, K., Yamaguchi, N., Saito, R., Akashi, K., Motoshima, H., \& Kawabata, J. (2005). Oral Administration of Freeze-Dried Kefir Reduces Intestinal Permeation of and Oral Sensitization to Ovalbumin in Mice. Bioscience, Biotechnology, and Biochemistry, 69(1), 249-251.

Van Hemert, S., Meijerink, M., Molenaar, D., Bron, P. A., de Vos, P., Kleerebezem, M., \& Marco, M. L. (2010). Identification of Lactobacillus plantarum genes modulating the cytokine response of human peripheral blood mononuclear cells. BMC Microbiology, 10(1), 293.

Vasiljevic T. \& Shah N. P. (2008). Probiotics - From Metchnikoff to bioactives. International Dairy Journal. 18 (7): 714-728.

Vesterlund, S., Salminen, K., \& Salminen, S. (2012). Water activity in dry foods containing live probiotic bacteria should be carefully considered: A case study with Lactobacillus rhamnosus GG in flaxseed. International Journal of Food Microbiology, 157(2), 319-321.

Vinderola C.G., Duarte J, Thangavel D, \& col. (2005). Immunomodulating capacity of kefir. J Dairy Res72,195-202.

Vinderola, C.G., Perdigon, G., Duarte, J., Thangavel, D., Farnworth, E., \& Matar, C. (2006). Effects of kefir fractions on innate immunity. Immunobiology, 211(3), 149-156.

Wallis, P.M., \& Wallis, H.M. (1986) Excystation and culturing of human and 
animal Giardia spp. by using gerbils and TYI-S-33 medium. Appl Environ Microbiol. 1986 Mar; 51(3):647-51.

Wang, J., Ma, T., Zhao, L., Lv, J., Li, G., Liang, F., \& Liu, R. (2008). PCR-DGGE method for analyzing the bacterial community in a high temperature petroleum reservoir. World Journal of Microbiology and Biotechnology, 24(9), 1981-1987.

Wang, L., Li, L., Lv, Y., Chen, Q., Feng, J., \& Zhao, X. (2018). Lactobacillus plantarum restores intestinal permeability disrupted by Salmonella infection in newly-hatched chicks. Scientific Reports, $8(1)$.

Wang, J., Ji, H., Wang, S., Liu, H., Zhang, W., Zhang, D., \& Wang, Y. (2018). Probiotic Lactobacillus plantarum promotes intestinal barrier function by strengthening the epithelium and modulating gut microbiota. Frontiers in Microbiology, 9.

Wang, Y. C., Yu, R. C., \& Chou, C. C. (2004). Viability of lactic acid bacteria and bifidobacteria in fermented soymilk after drying, subsequent rehydration and storage. International Journal of Food Microbiology, 93, 209-217.

Weingarden, A., González, A., VázquezBaeza, Y., Weiss, S., Humphry, G., BergLyons, D., \& Sadowsky, M. J. (2015). Dynamic changes in short- and long-term bacterial composition following fecal microbiota transplantation for recurrent Clostridium difficile infection.

Microbiome, 3(1).

Yan, F., \& Polk, D. B. (2011). Probiotics and immune health. Current opinion in gastroenterology, 27(6), 496-501.

Ying, D. Y., Phoon, M. C., Sanguansri, L., Weerakkody, R., Burgar, I., \& Augustin, M. A. (2010). Microencapsulated Lactobacillus rhamnosus GG powders: relationship of powder physical properties to probiotic survival during storage. Journal of Food Science, 75, E588-E595.

Ying, D., Sun, J., Sanguansri, L., Weerakkody, R. \& Augustin, M.A. (2012) Enhanced survival of spray-dried microencapsulated Lactobacillus rhamnosus $\mathrm{GG}$ in the presence of glucose. Journal of Food Engineering; 109(3):597-602.

Zacarías, M. F., Reinheimer, J., Forzani, L., Grangette, C., \& Vinderola, G. (2014). Mortality and translocation assay to study the protective capacity of Bifidobacterium lactis INL1 against Salmonella Typhimurium infection in mice. Beneficial Microbes, 5(4), 427436.

Zheng, X.; Fu, N.; Duan, M.; Woo, M.W.; Selomulya, C. \& Chen, X. D. (2015). The mechanisms of the protective effects of reconstituted skim milk during convective droplet drying of lactic acid bacteria. Food Res. Int. $76: 478-488$

Zhou, P.; Li, E.; Shea-Donohue, T. \& Singer, S.M. (2007). Tumour necrosis factor alpha contributes to protection against Giardia lamblia infection in mice. Parasite Immunol; 29: 367-374.

Zihni, C., Mills, C., Matter, K., \& Balda, M. S. (2016). Tight junctions: from simple barriers to multifunctional molecular gates. Nature Reviews Molecular Cell Biology, 17(9), 564-580.

Zivkovic, M., Cadez, N., Uroic, K., Miljkovic, M., Tolinacki, M., Dousova, P., \& Golic, N. (2015). Evaluation of probiotic potential of yeasts isolated from traditional cheeses manufactured in Serbia and Croatia. Journal of Intercultural Ethnopharmacology, 4(1), 12. 